$$
\begin{aligned}
& \text { تغير الثتوى } \\
& \text { أسبابه وضوابط وتطبيقاته في الثة الإسلامي } \\
& \text { إعداد } \\
& \text { الاكتور } \\
& \text { محمد أحمد علي أبو الثيخ } \\
& \text { أستاذ الثريعة الإسلامية المساعد } \\
& \text { كلية دار العلوم-جامعة أسوان }
\end{aligned}
$$




\section{هلمص البمث}

الحمد لله رب العالمين والصلاة وإلسلام على خاتم النبيين سيدنا محمد وعلى آله وصحبه أجمعين، ومن تبعهم بإحسان إلى يوم الدين.

وبعد:

فيمكن تلخيص بحث تغير الفتوى في النقاط الآتية:

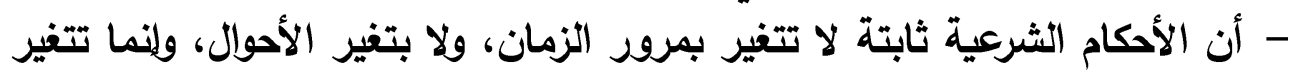

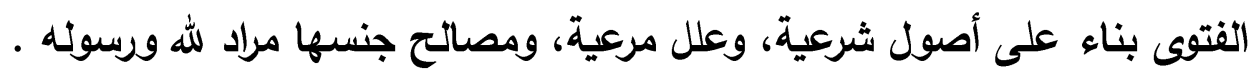

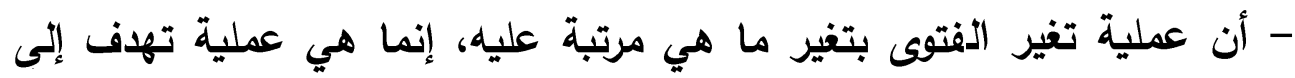

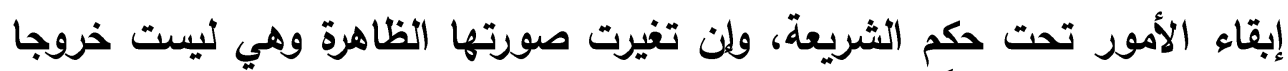
على الثريعة واستحداثًا لأحكام جديدة.

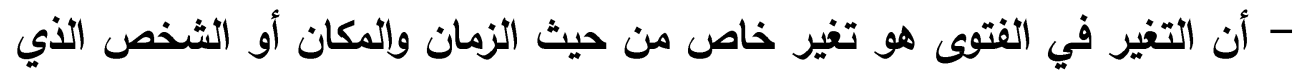

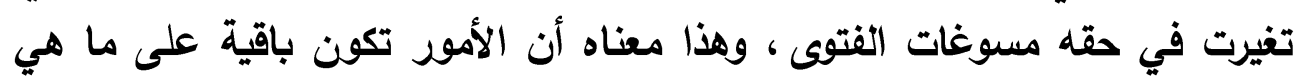

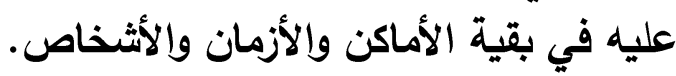

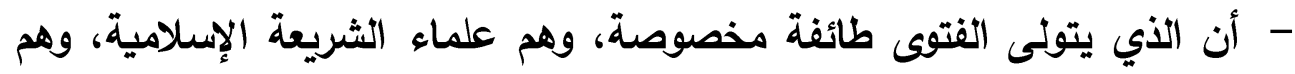

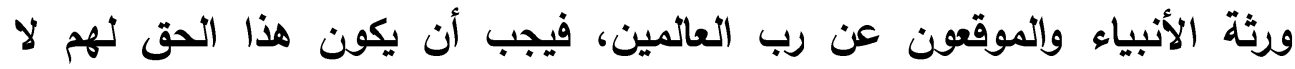

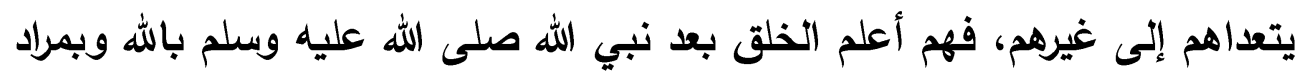

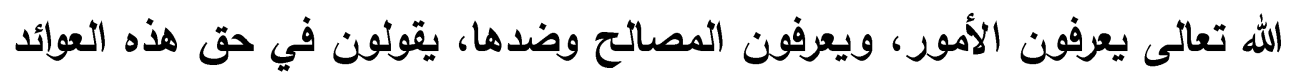

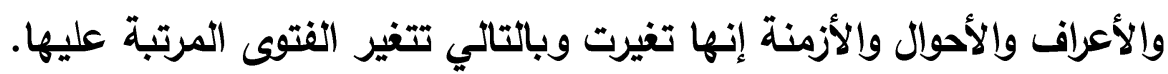

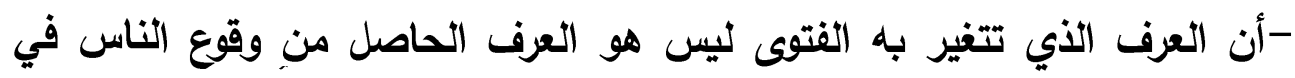

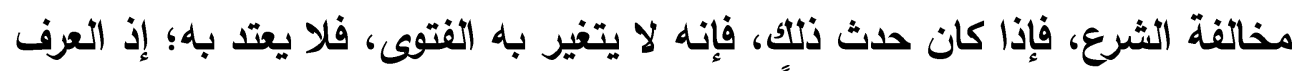

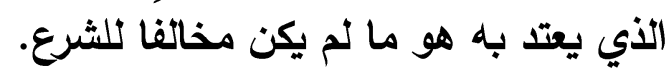

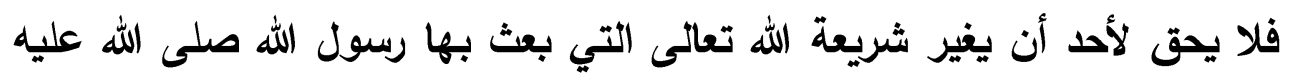

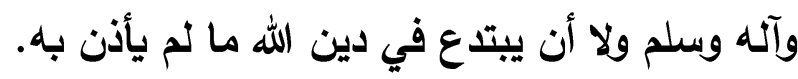
وآخر دعوانا أن الحمد لله رب العالمين وصلى دئ الله على سيدنا محمد وعلى آله وصحبه ومن والاه. 
Abstract

Many thanks to Allah an pray be upon prophet Mohammed and his followers.

The research could be summarized in the following points:

1- Islamic Rules and regulations are fixed and stable and cannot be changed by time or status.

2-Changing Fatwa depends mainly on the results of such Fatwa without the change of basics and rules of religion.

3-Changing fatwa means the change of it according to place and time but not the change of the Fatwa itself.

4- Not all people are qualified for Fatwa, but those who are specialized in Fatwa and those who are academically qualified are responsible for it.

5- Fatwa doesn't change with mistakes and bad deeds committed by people as it is not related to faults of others.

Then, it is clear that people are not able to change religious according to their desires and prophet Mohammed (PBUHI) is the only one from which we can receive our religious regulations and instructions.

Thanks for Allah and his prophet and his followers. 


\section{المقدمة}

الحمد اله رب العالمين، وإلصَّلاة والسلام على سيد الأنبياء وإلمرسلين سيدنا محمد

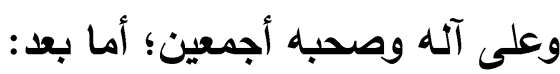

فإن الفتيا مقامها في دين الله مقام عظيم، لا يجوز الاستهانة بهاه، ولا توليته لمن ليس أهلاً له؛ ويحذرون من ذلكت، ويتورعون عن كثرة الإفتاء.

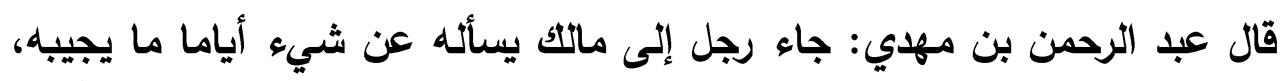

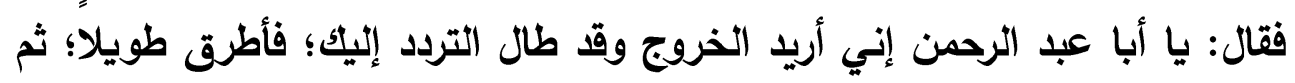

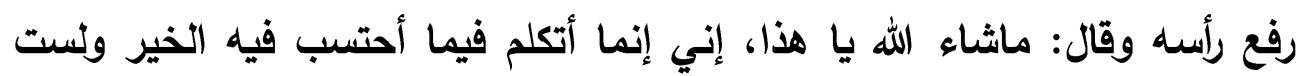
أحسن مسألتك هذه وفال: ماثناء

وسئل الثافعي عن مسألة، فسكت، فقيل له: ألا تجيب يرحمك الله، فقال: حتى

$$
\text { أدري الفضل في سكوتي أو في الجواب. }
$$

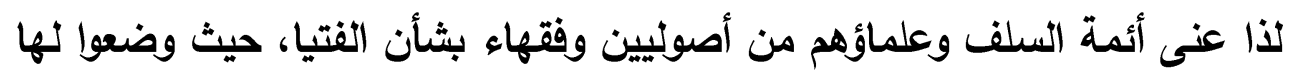
القواعد، وبينوا الثروط التي يلزم تحققها في المفتي والمستفتي.

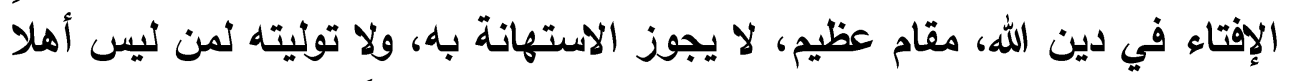

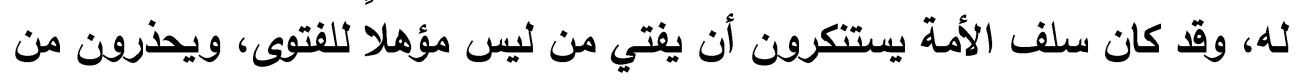
ذلك، ويتورعون عن كثرة الإفتاء.

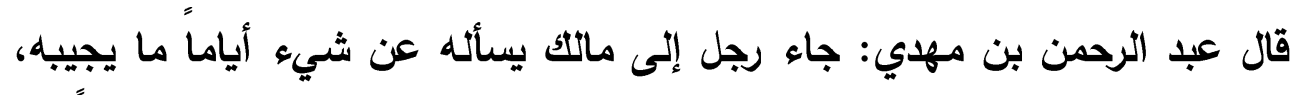
فقال: يا أبا عبد الرحمن: إني أريد الخروج وقد طال التردد إليك، فأطرق طويلا، ثماء

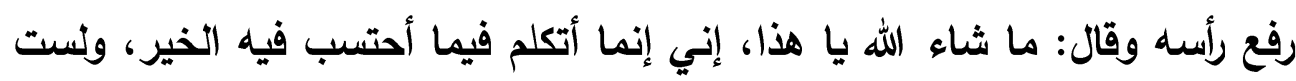
أحسن مسأنتك هذه. 
وسئل الثعبي عن مسألة؟ فقال: لا أدري، فقيل له: ألا تستحي من قول لا أدري،

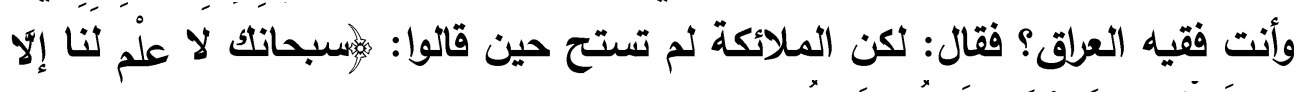

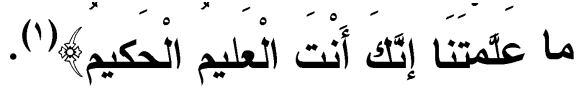

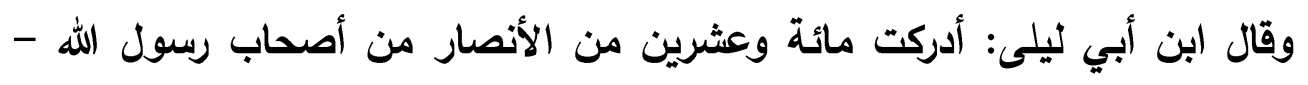

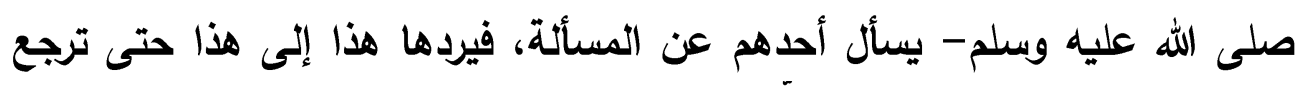

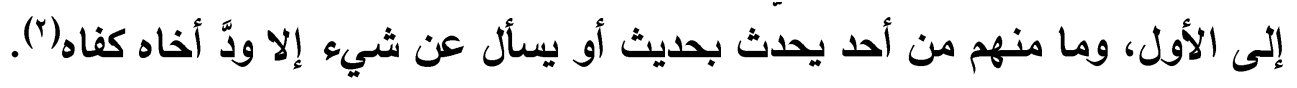

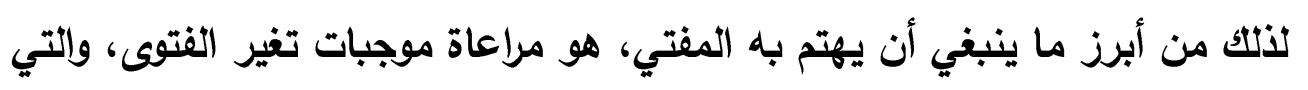

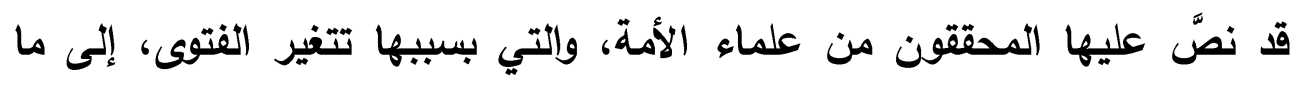

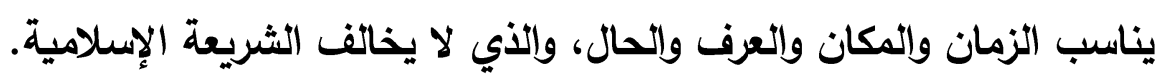

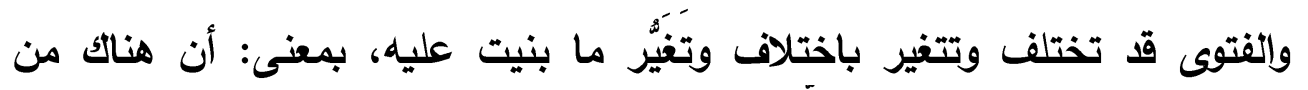

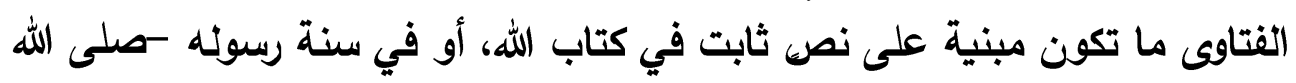

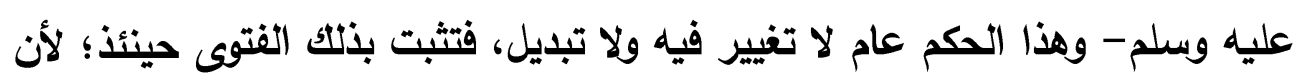

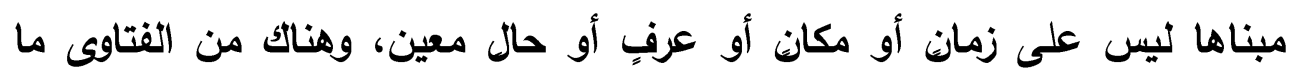

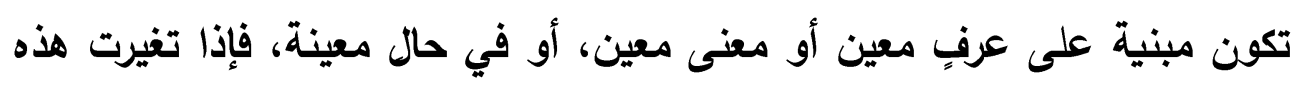

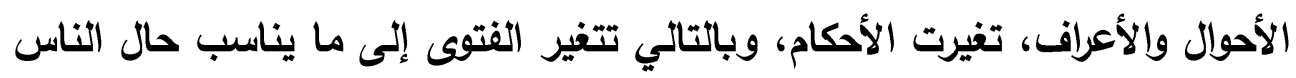

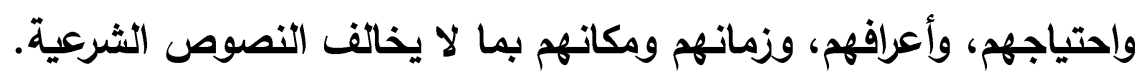

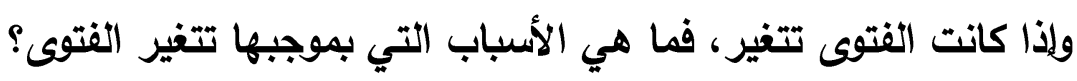

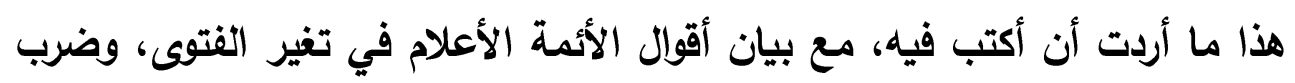

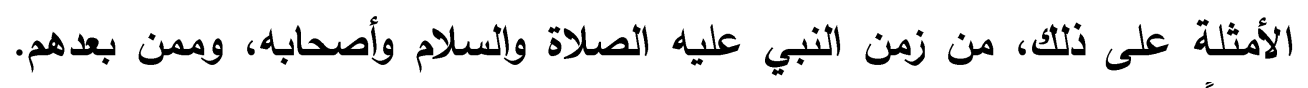

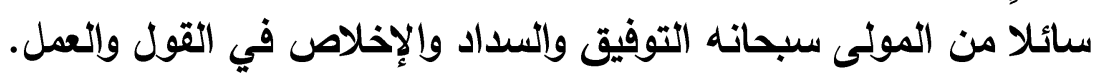

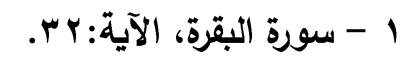

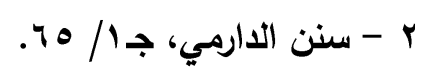


وسيكون السير في هذا البحث على النحو التالي: الفصل الأول: مفهوم تغير الفتوى

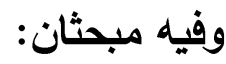

المبحث الأول: المستند الشرعي لتغير الفتوى المبحث الثاني: مصادر مشروعية التفير وفيه مطلبان:

المطلب الأول: مشروعية التغير في السنة النبوية المطلب الثاني: ضوابط تغير الفتوى الفصل الثاني: الفرق بين مصطلح تغير الفتوى، ومصطلح تغير الأحكام وفيه خمسة مباحث: المبحث الأول: تنظير القول بتغير الأحكام المبحث الثاني: مراد العلماء الأين أطلقوا القول بتغير الأحكام المبحث الثالث: مراعاة تغير الفتوى الاجتهادية بتغير الزمان والمكان والأعراف المبحث الرابع: من الذي يتولى تغيير الفتوى؟ المبحث الخامس: ماهية تخيز الفتوى الفصل الثالث: الأسباب المؤدية إلى تغير الفتوى المبحث الأول: السبب الأول: تغير الزمان وفيه مطلبان: المطلب الأول: معنى تغير الزمان المطلب الثاني: أمثلة على تغير الفتوى بتغير الزمان المبحث الثاني: السبب الثاني: تغير المكان 
المبحث الثالث: السبب الثالث: تغير العادات وفيه خمسة مطالب: المطلب الأول: معنى تغير العادات المطلب الثاني: أمثلة على تغير الفتوى بتغير العرف المطلب الثالث: ضابط تغير الفتوى بتغير العرف المطلب الرابع: شروط العلماء رحمهم الله تعالى في اعتبار العرف المطلب الخامس: أمثلة على تغير الفتوى بتغير العرف المبحث الرابع: السبب الرابع: تغير الأحوال المبحث الخامس: تغير الفتوى لأسباب ناجمة عن أفعال مباحة أو مندوبة وفيه سبعة مطالب: المطلب الأول: النظر في العواقب المطلب الثاني: تغير الفتاوى لتغير نظرة المجته المطلب الثالث: تشربع لحالة مؤقتة المطلب الرابع: الاستثناء ثلحاجة المطلب الخامس: تغير الحكم بسبب تغير علته المطلب السادس: استحداث أحكام المطلب السابع: الاستحسان المبحث السادس: التصوص التي لا تقبل التغير، والتصوص التي تقبل تغيير الاجتهاد فيها ثَبَت المصادمة وأهم النتائجج 


\section{الفصل الأول}

\section{مفهوم تغير الفتوى}

يقصد بتغير الفتوى أن الفتوى تختلف في بيان حم المسألة الواحدة من حال لآخر، أومن

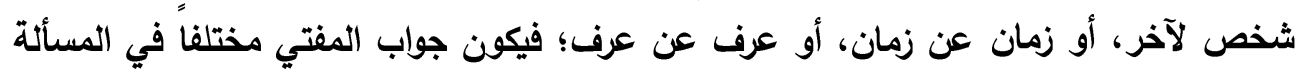

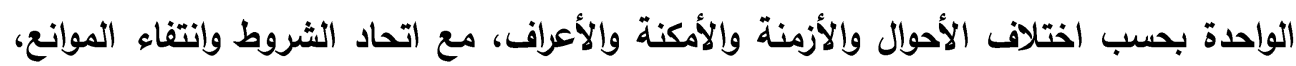
فإن اختلفت الثروط أو وجدت الموانع فلا اتحاد، بل يكون لكل مسألة حكم مستقل؛ فأخذ مال

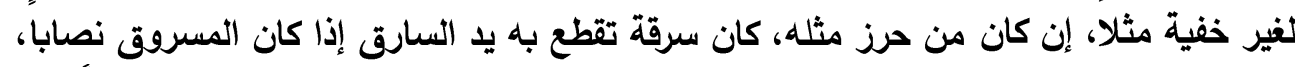

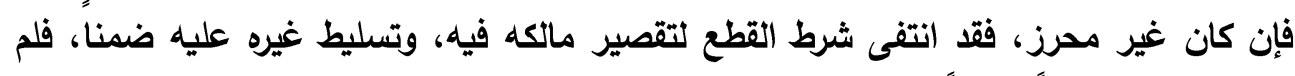

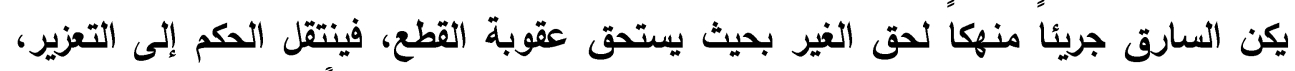

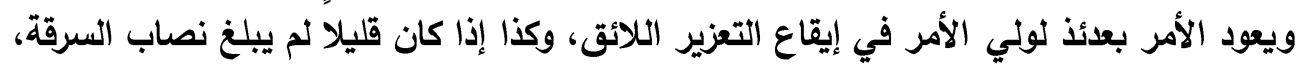

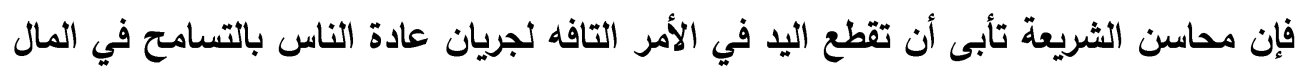
التافه.

فوجود المانع وهو عدم كون المال نصاباً يقتضي أن يختلف حمم السرقة من قطع إلى تعزير،

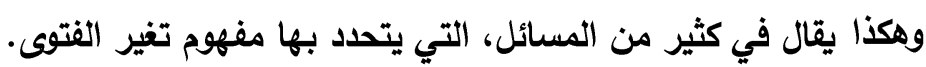

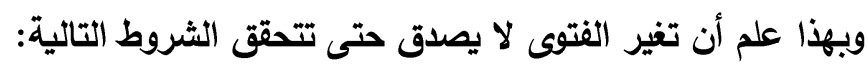

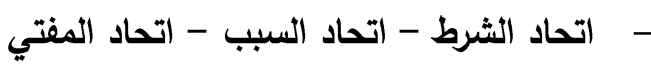

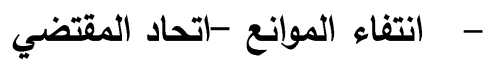

فإن توافرت هذه الثروط بحثنا عندئذ عن سبب تغير الفتوى فيما مضى، أو إمكان تغيرها مع أفعاد هذا السبب في الحاضر أو المستقبل. فاتحاد الثرط يقتضى أن المسألة في صورتيها، شدة وخفة: واحدة؛ وذلك كقتل البالغ العاقل،

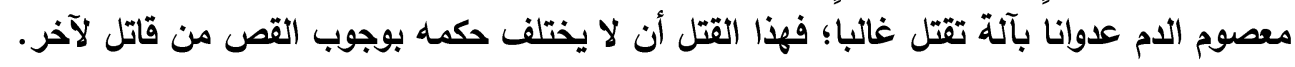

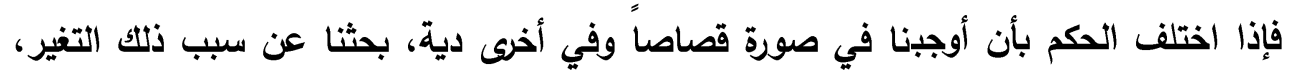

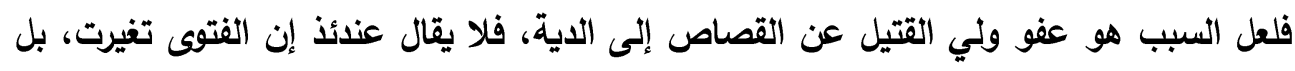

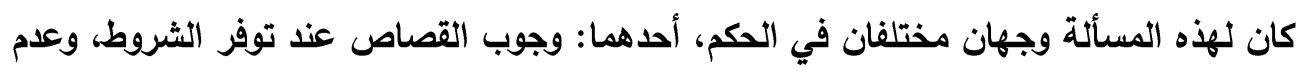
العفو، والآخر الدية عند العفو عن القصاص إليها أو بدونها مع توفر الثروط الأخرى. 


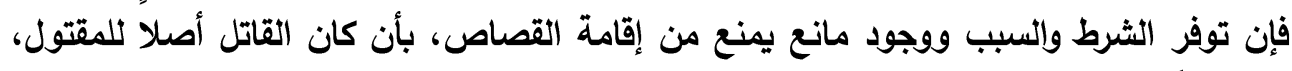

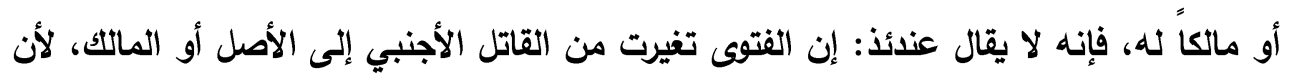

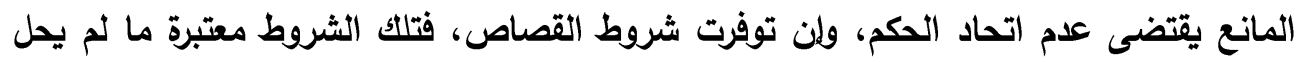

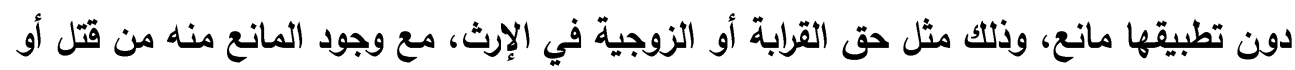

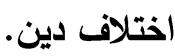
فإن توفرت الثروط والأسباب وانتفت الموانع واختلف فيها المفتي بأن قال فيها مفت غير ما قال

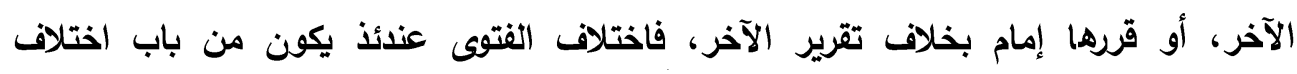

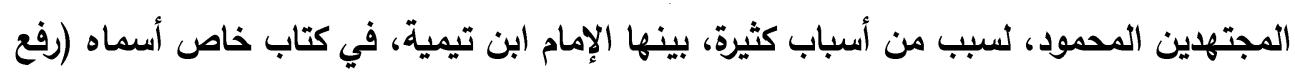

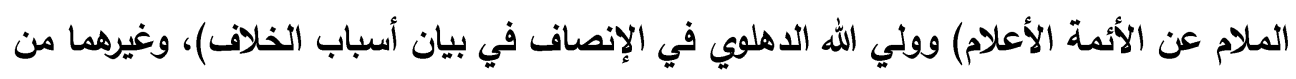

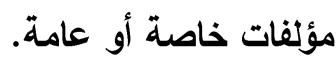
فاختلاف الفتوى مع اختلاف المفتين هو من باب تعداد الاجتهاد الذي أقره النبي صلى الله عليه

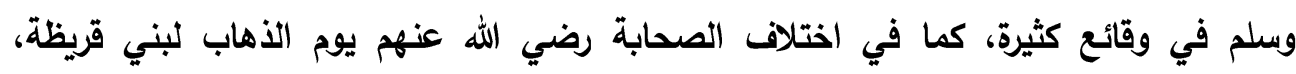

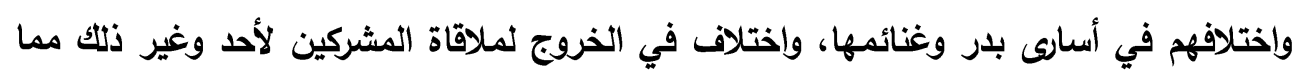
هو معلوم ضرورة ولا ينكره أحد. أما إذا اتحد السبب والثرط ولكن اختلف المقتضي كمسألة إقامة الحدود والقصاص في الجهاد

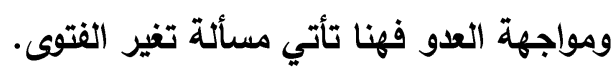

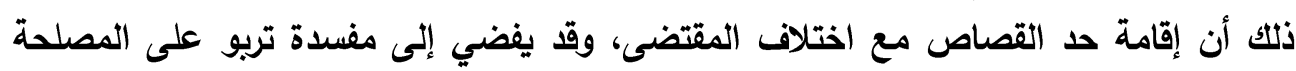

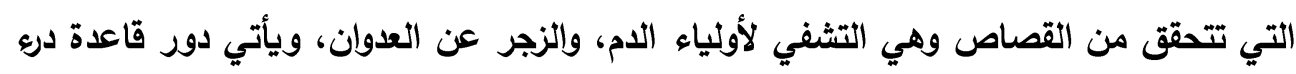

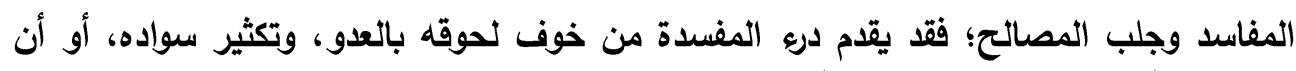

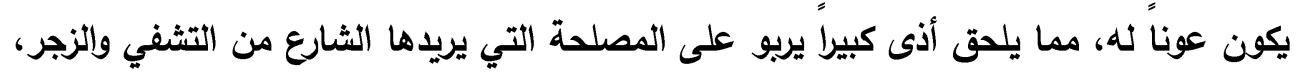

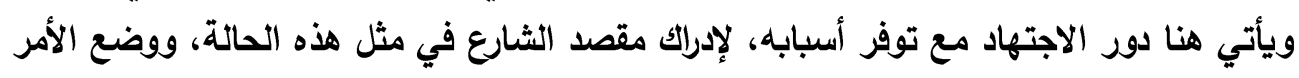

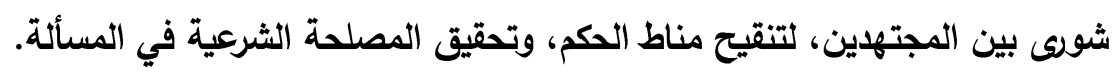
ولا ريب أن هذا الاختلاف أو التغير مما درجت عليه الثريعة واقتضته نصوصها. 
فإن الشريعة جاءت لتحقيق مقاصد إيجابية هى لب التشريع، وهذه المقاصد هي: المعاني والحكم

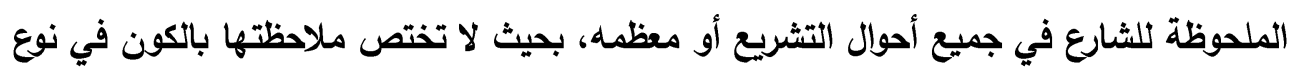
خاص من أحكام التشريع('). فيراعي الثارع تحقيقها ولو أدى ذلك لتغير أحكامه كما حدث في نسخ بعض الأحكام إلى بلال أو

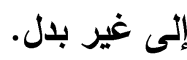
وقد اتفق العلماء على أن هناك كليات حافظت عليها الثرائع السماوية، وهي: الدين، والنفس، والعقل، والنسل، والمال(r). وقد أولتها الثريعة عناية خاصة، بحيث أباحت من أجل تحقيقها المحظورات عند الضرورات

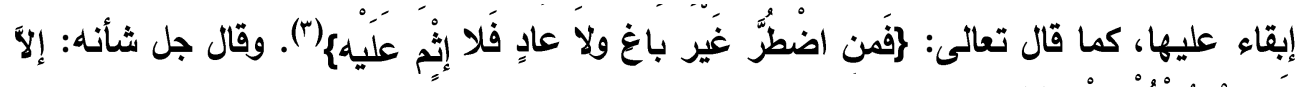

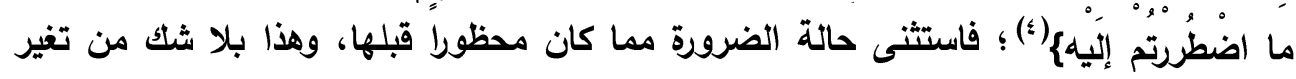
الفتوى.

ولهزذا يقول الإمام الغزالي رحمه الله تعالى: (ومقصود الشارع من الخلق أن يحفظ عليهم دينهم

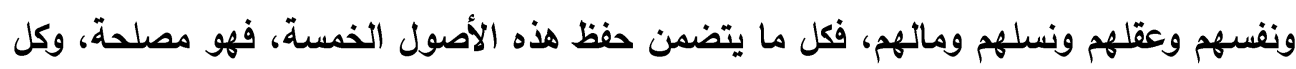

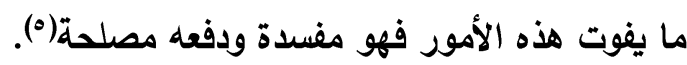

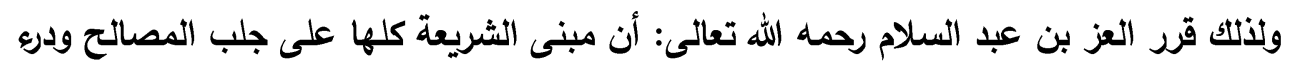
المفاسد ("). وهذه المقاصد هي التي يبحث عذها المجته عندما يرى أن حكم المسأثة الثائع الذائع لا ينطبق

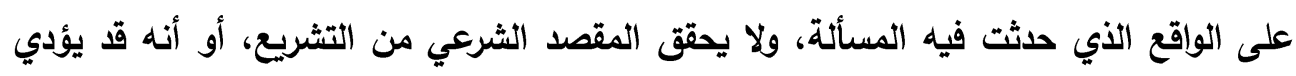

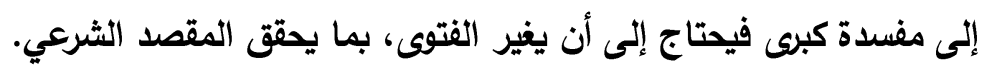

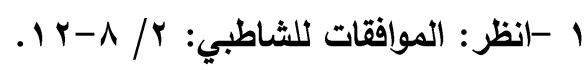

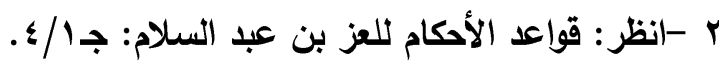

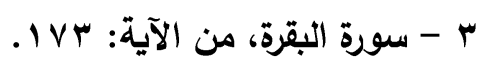

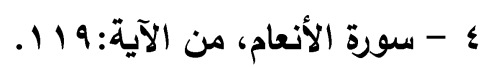

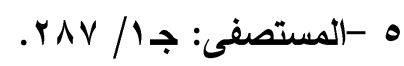
4 -ققواعد الأحكام عن مصالح الأنام: ؛. 


\section{البمشث الأهول}

\section{المستند الثرعي لتغيز الفتوى}

حينما نبه العلماء على أصل تغير الفتوى، وأوردوا على ذلك أمثلة، أشاروا عند كل مثال إلى

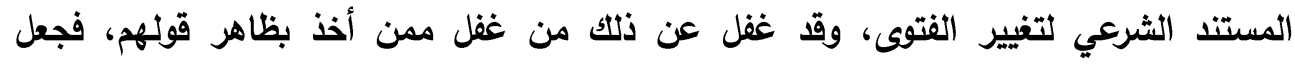

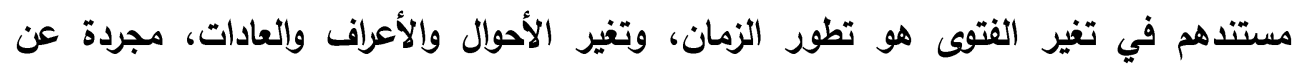

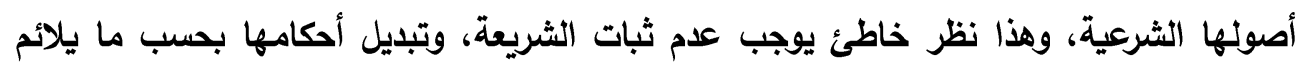

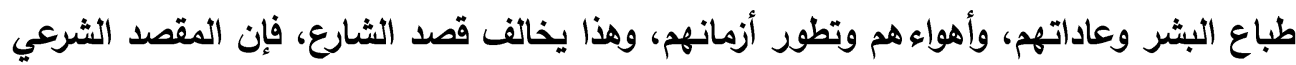

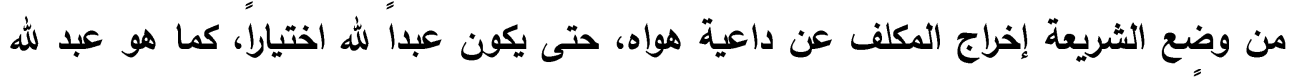

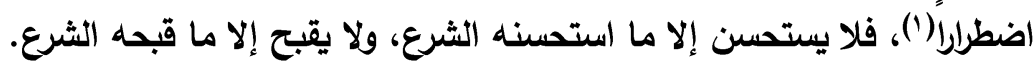

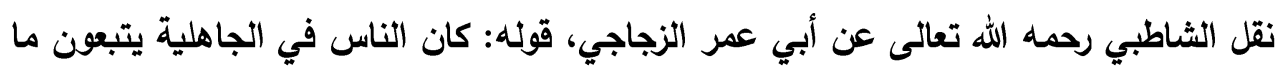

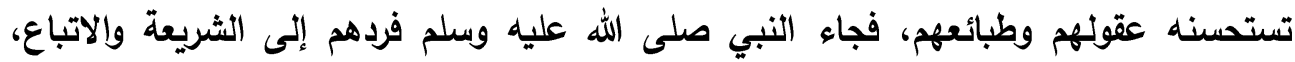

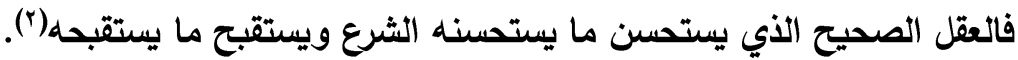

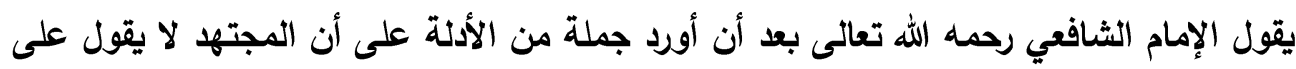

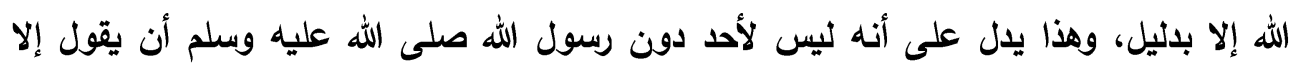

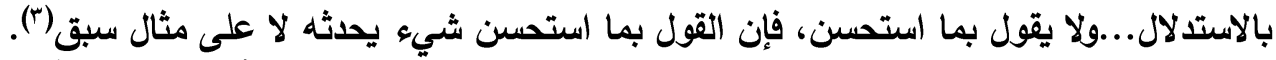

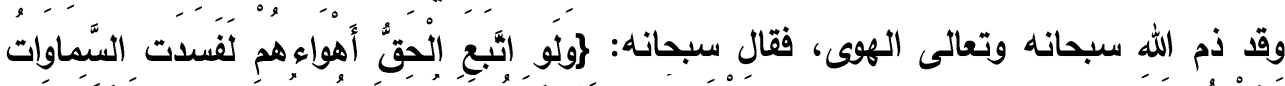

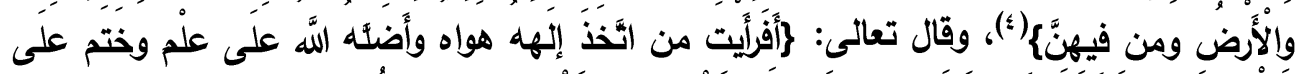

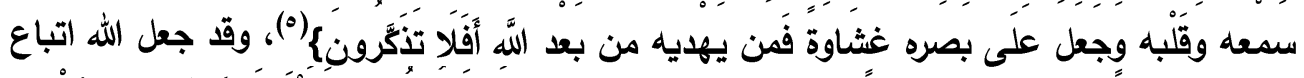

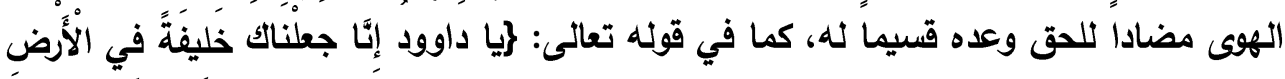

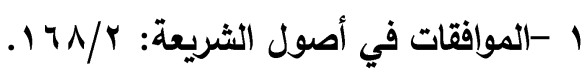

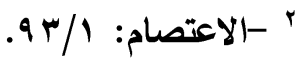

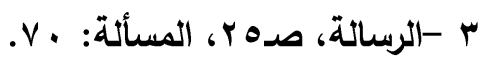

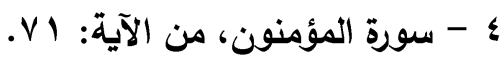

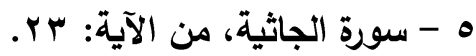




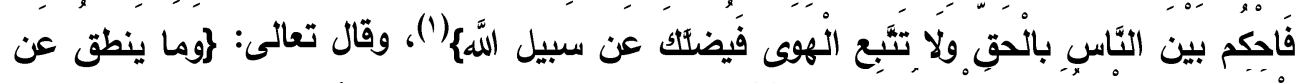

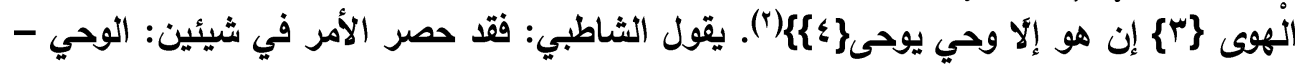

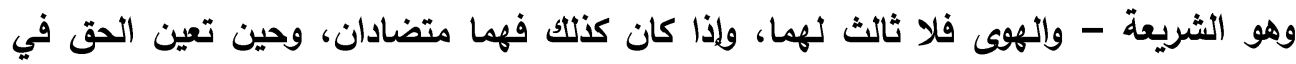

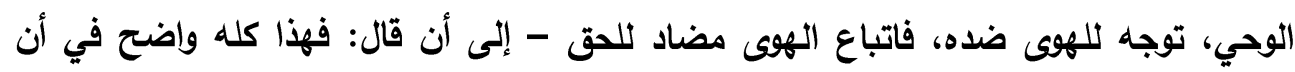

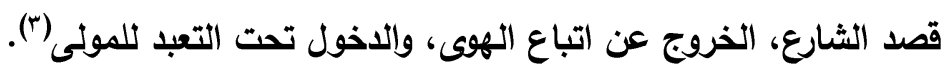

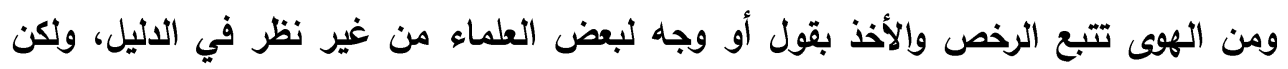

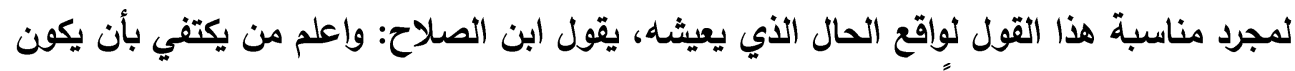

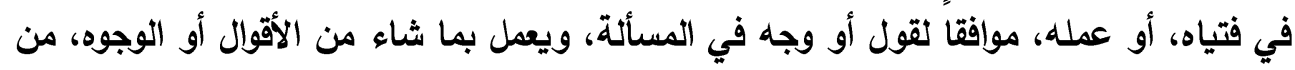

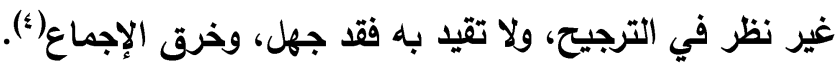

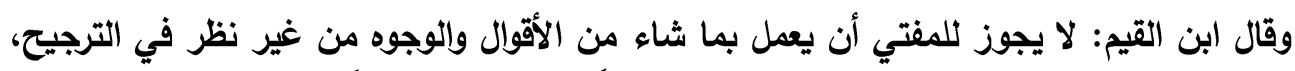

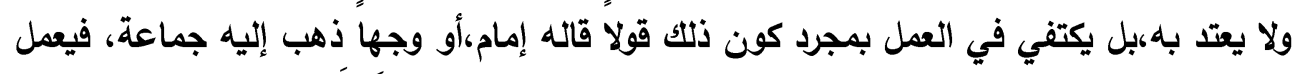

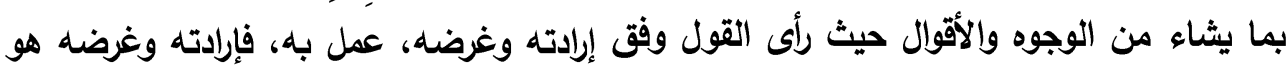

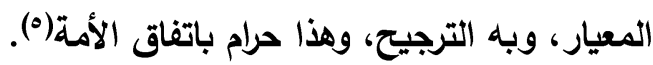

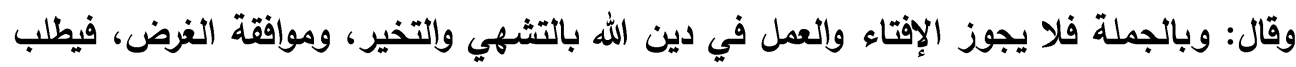

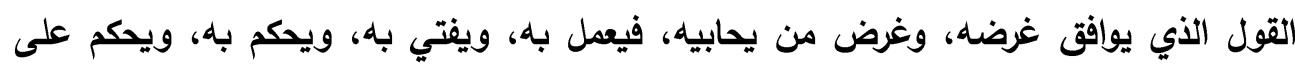

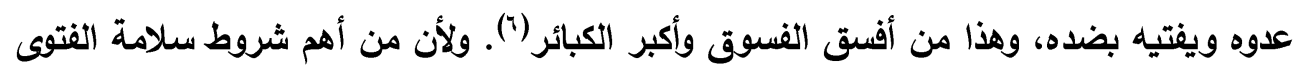

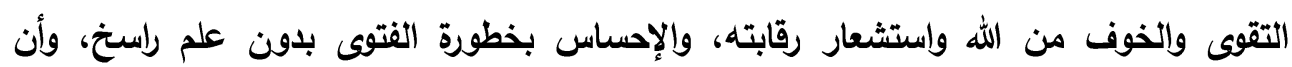

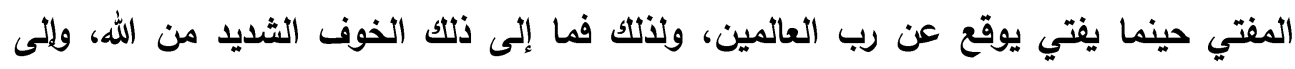

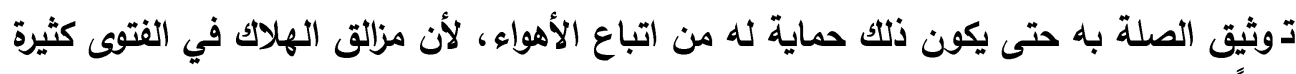
جدا، بل إذا لم يلتزم بالثروط والضوابط الخاصة بها، ولم يلتزم بالثريعة فتكون هناك الهواء الثاء

$$
\text { r - سورة ص، من الآية: بورة النجم، الآيتان: r، ؛. }
$$

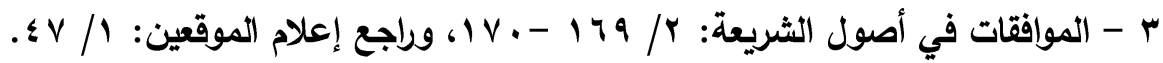

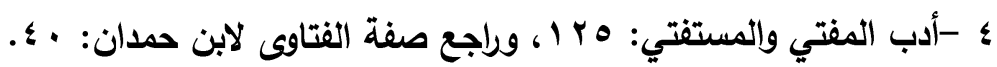

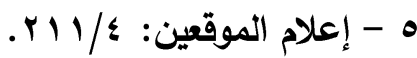

$$
\begin{aligned}
& 4
\end{aligned}
$$


وضغوط الواقع، ولذلك حذر الله تعالى من ذلك،، فقال تعالى: "ثم جعلناك على شريعة من الأمر

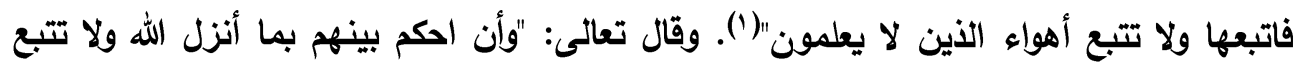

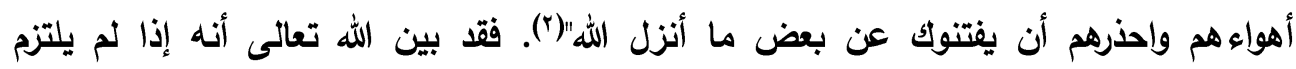

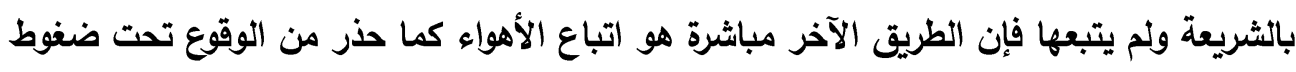

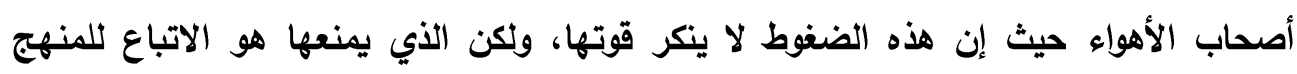

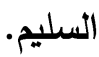

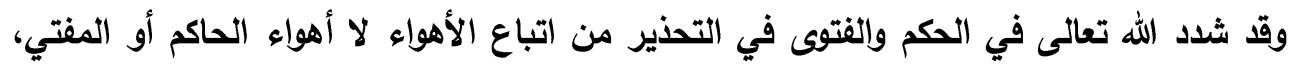

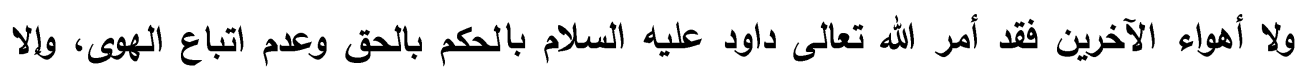

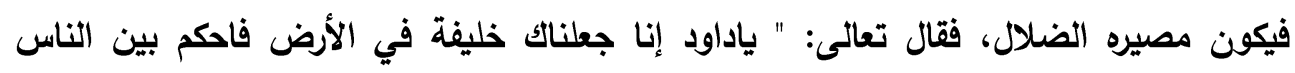

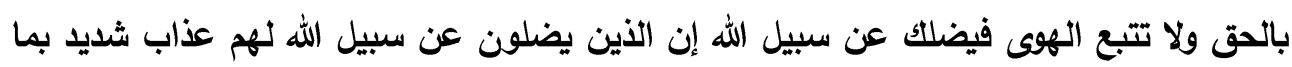

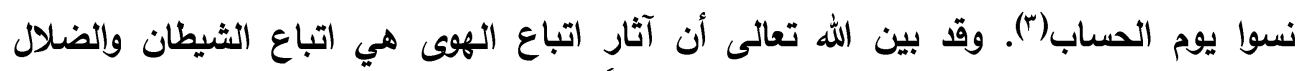

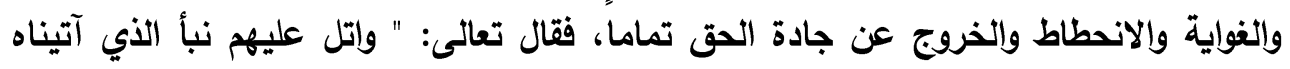

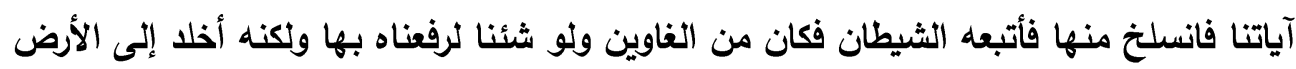

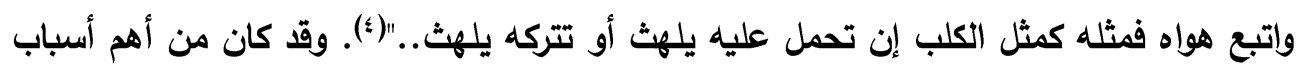

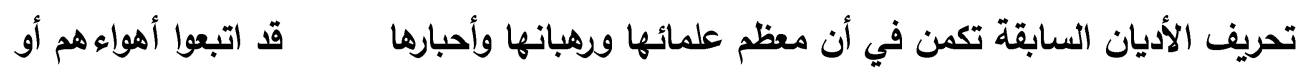

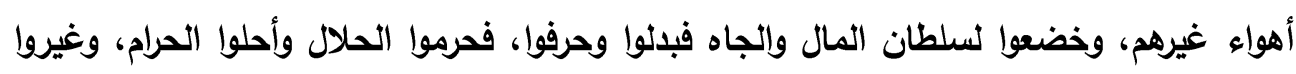

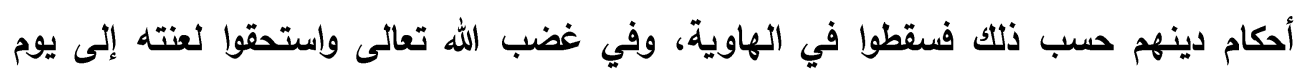
الدين.

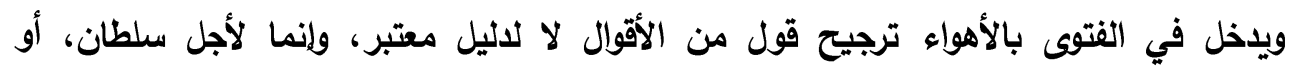

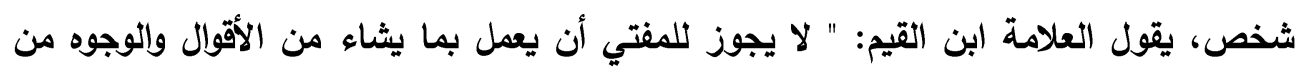

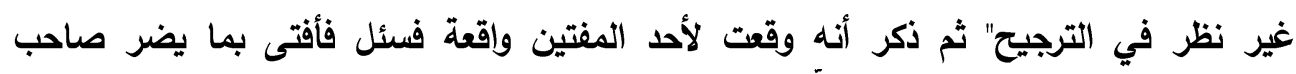

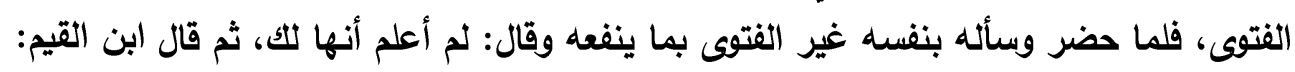

$$
\begin{aligned}
& \text { ' - سورة الجاثية، الآية: 11. } \\
& \text { r - سورة المائدة، الآية: } 9 \text { ؛. } \\
& \text { r - سورة ص، الآية: بون، الايه: }
\end{aligned}
$$

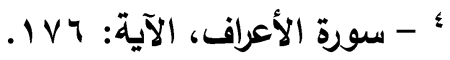


" وبالجملة فلا يجوز العمل والإفتاء في دين الله بالتشهي والتحيز وموافقة الغرض، فيطلب القول الذي يوافق غرضه، وغرض من يحابيه فيعل به ويفتي به ويحكم به ... ويحكم على عدوه

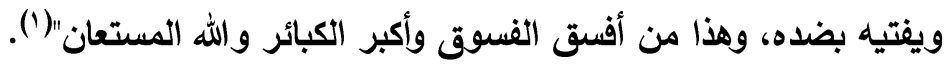

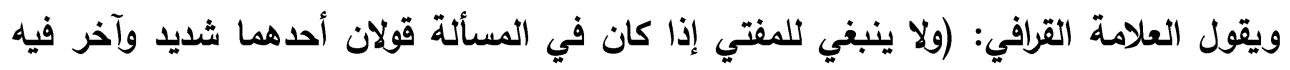

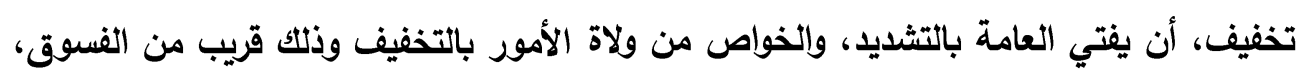

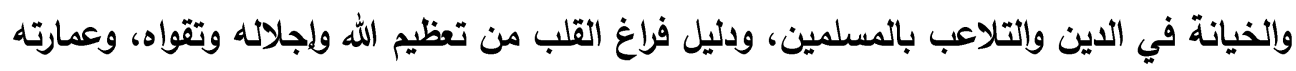

باللعب وحب الرياسة والتقرب إلى الخلق دون الخالق نعوذ بالله من صفات الغافلين) (انَ.

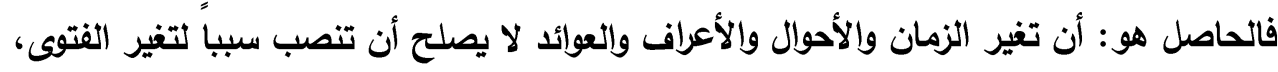
دون ربطها بالأصول الثرعية، والعلل المرعية، وإلمصالح التي جنسها مراد الله ورسوله صله الته الله

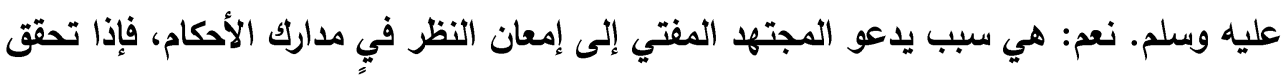

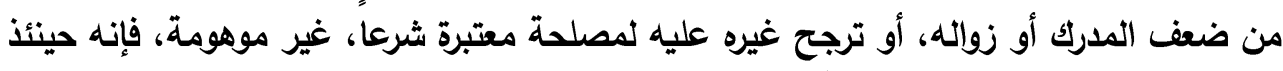

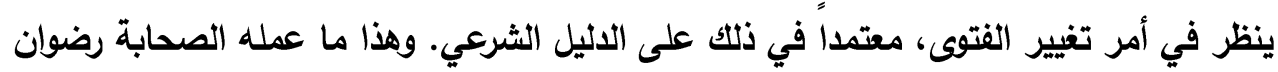

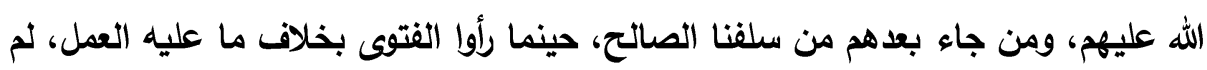

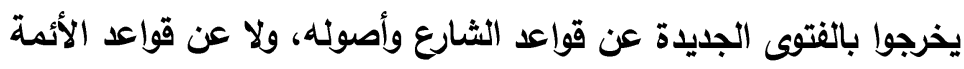

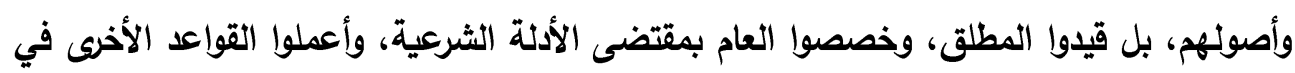

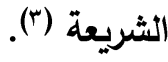

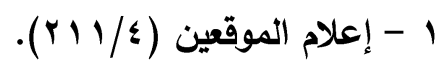

$$
\begin{aligned}
& \text { r - الاحكام في تميز الفتاوى، ص (rV. (Y). }
\end{aligned}
$$

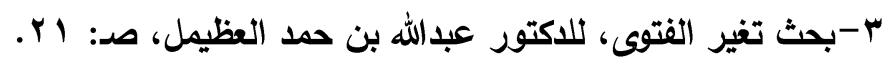




\section{المبمث الثاني \\ مصادر مشروعية التغير}

مشروعية التغير لابد لها من دليل معترف به في مبحث أدلة الأحكام من أصول الفقه، وحسبنا هنا، الأدلة الأصلية وهي القرآن والسنة. - مشروعية التغير في القرآن الكريم:

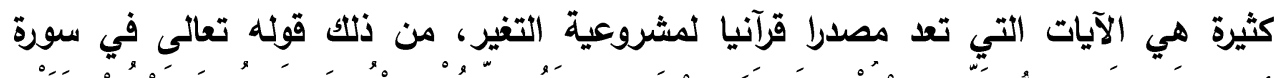

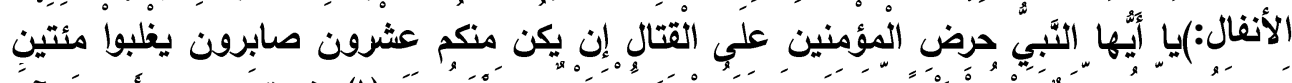

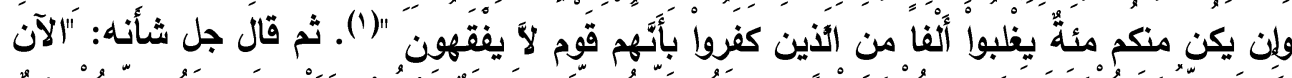

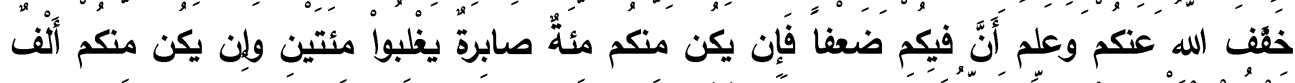

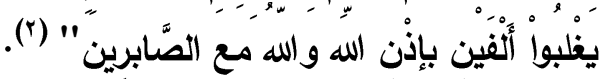

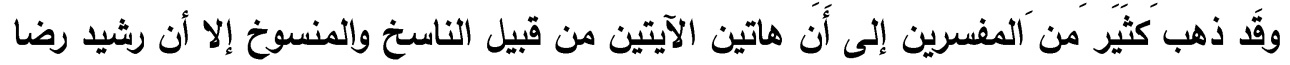

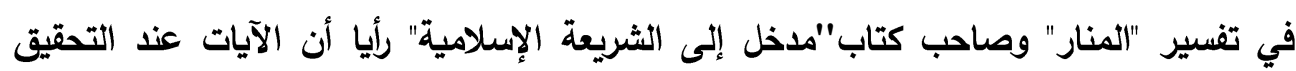

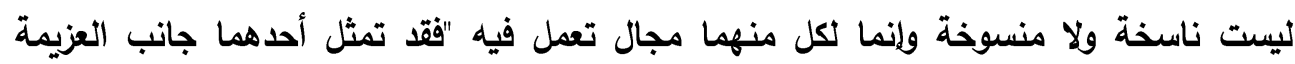
والأخرى جانب الرخصة، أو تكون أحدهما للإلزام والإيجاب والأخرى للندب والأستحباب، أو أحدهما

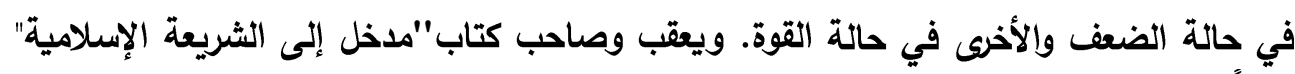

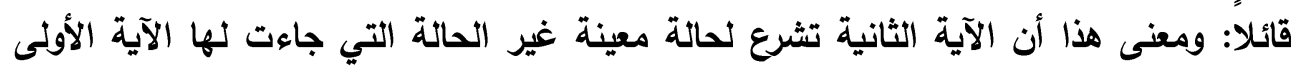
وهذه أصل لتغير الفتوى بتغير الأحوال.

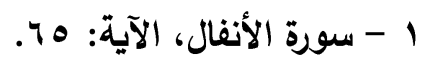

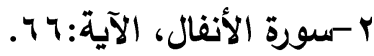




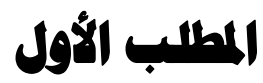 \\ مشروعية التفير في السنة النبوية}

في السنة النبوية أحاديث كثيرة تؤكد ما جاء في القرآن الكريم من مشروعية تغير الأحكام الأبهات

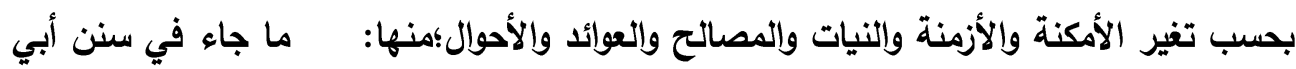

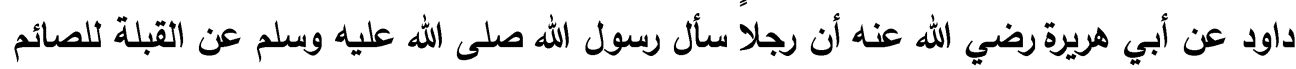

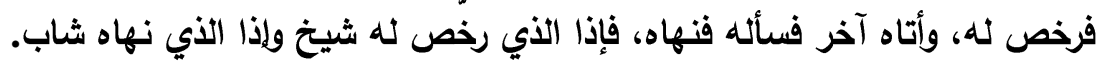

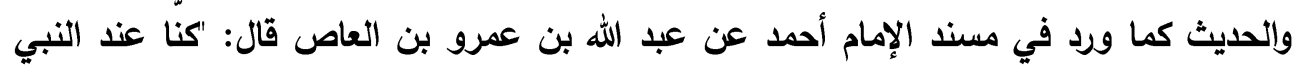

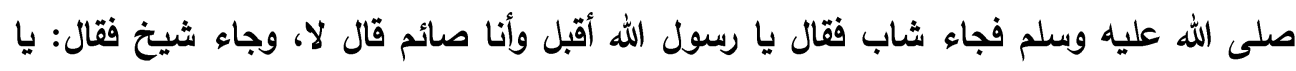

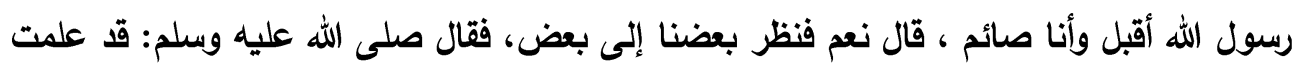
نظر بعضكم إلى بعض إن الثيخ يملك نفسه".

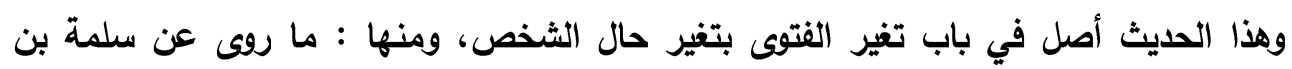

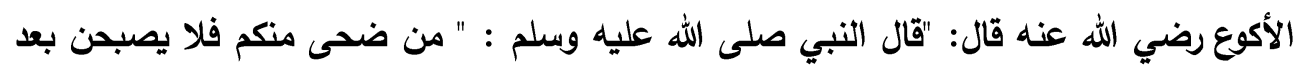

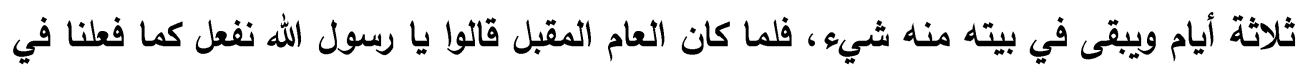

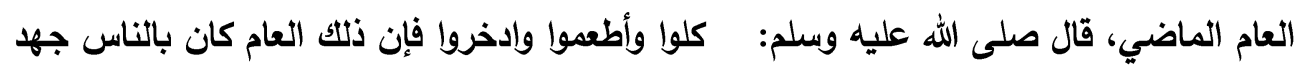

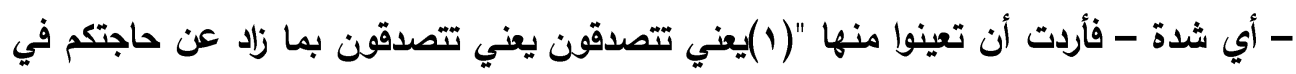

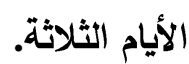

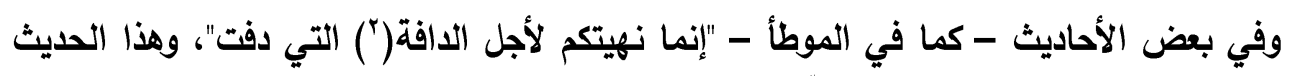

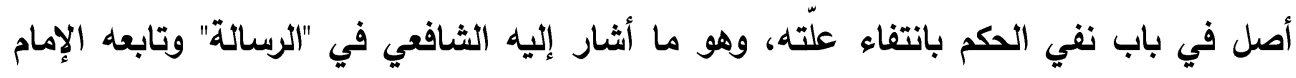

1 - صحيح البخاري « الأضاحي « باب ما يؤكل من لحوم الأضاحي وما يتزود منها.

r - قال أهل اللفة ) : الدافة ( بتشديد الفاء : قوم يسيرون جميعا سيرا خفيفا ، ودف يدف بكسر

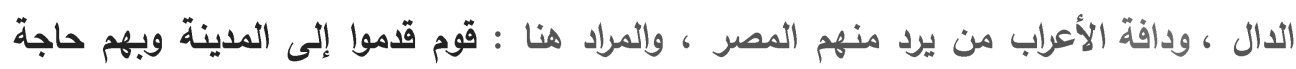

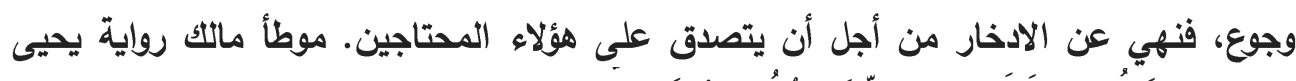

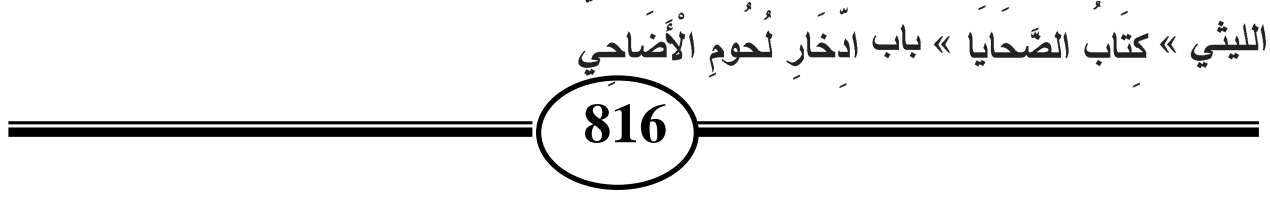


القرطبي في الجامع لأحكام القرآن فقال: "هو حكم ارتفع بارتفاع علته لا لأنه منسوخ، وفرق بين

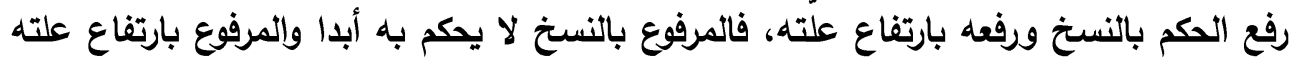

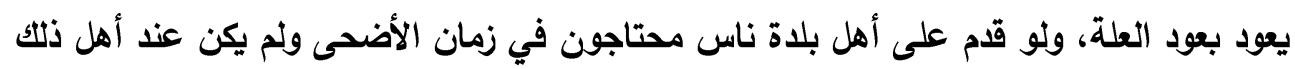

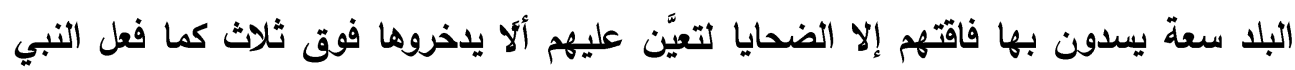
صلى الله عليه وسلم.

وقال الحافظ بن حجر في "فتح الباري" "والتقيد بالثلاث واقعة حال، والا فلو لم نسد الحاجة إلا

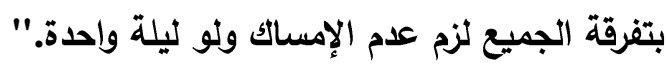
فالرسول كما جاء في السنة أفتى في حال بمنع ادخار لحوم الأضاحي وفي حال أخرى أفتى لألى

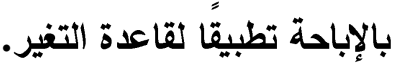
وهنا ينبغي التنبيه إلى أمرين:

الأول : أن التغير لم يكن حكما بالعقل المحض ولنما التما استجابة لأوامر جاءت في الكتاب والسنة.

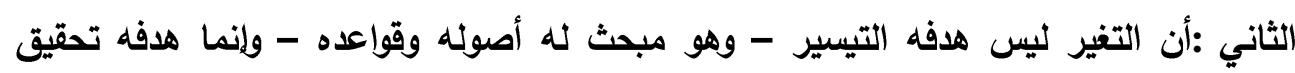
الأحكام لغاياتها ومقاصدها سواء كان التغير إلى التخفيف أو إلى التشديد.

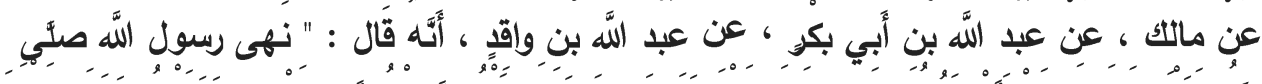

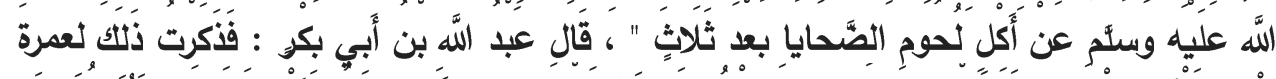

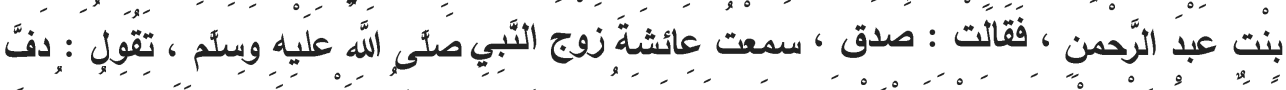

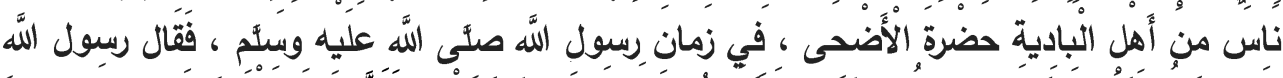

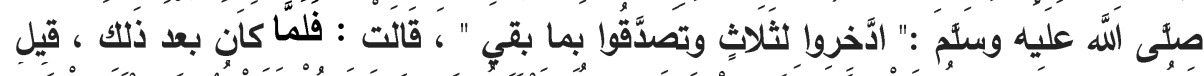

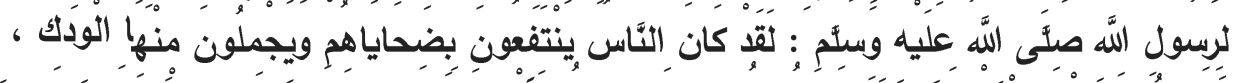

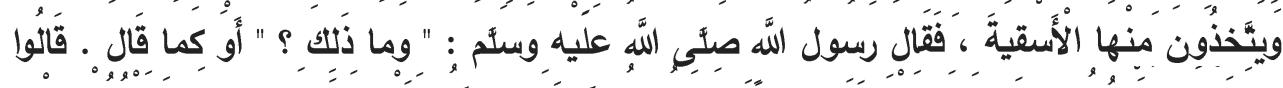

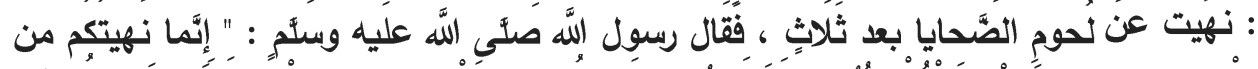

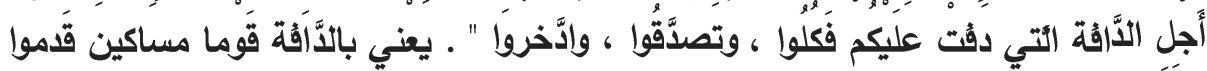
الْداينةً 


\section{البالب الثاني \\ ضوابط تغير الفتوى}

ولما كان المفتي مخبراً عن الله تعالى في بيان شرعه، وموقعاً عنه في بيان حكمه، فإنه لا

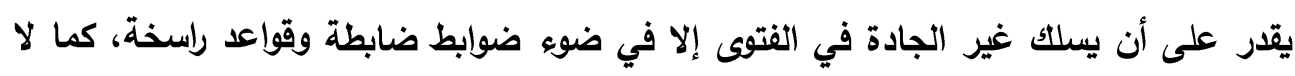

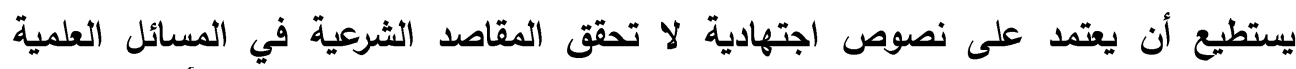

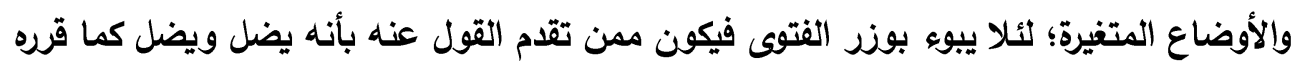
القرافي وابن القيم وغيرهما. لذلك كان لابد من ضوابط لتفيط لتفير الفتوى لتكون مؤصلة تأصيلاً

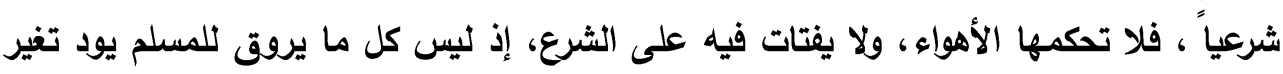

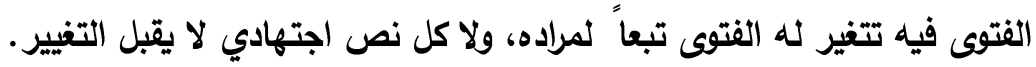

$$
\text { وأهم هذه الضوابط ما يلى: }
$$

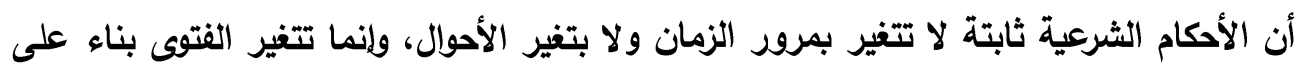

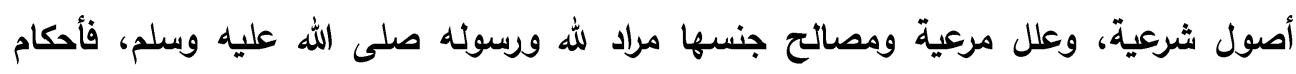
الشربعة تتنوع إلى نوعين: النوع الأول: أحكام نصية: وهي الأحكام الثابتة بنص شرعي نوعي مثل وجوب الصلاة والزكاة ووجوب

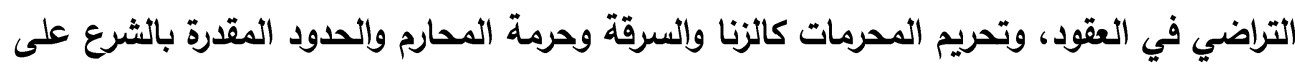

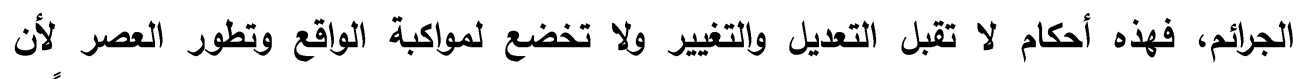
مقاصدها لا تتغير، بل هي من الثوابت التي يقصد بها حماية مقاصد شرعية كبرى لا تلتير أبداً.

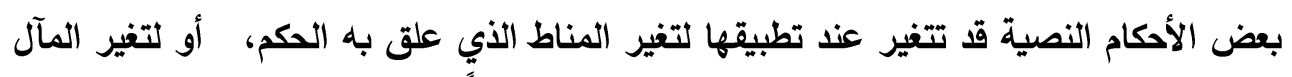

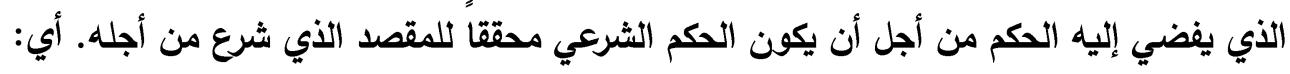

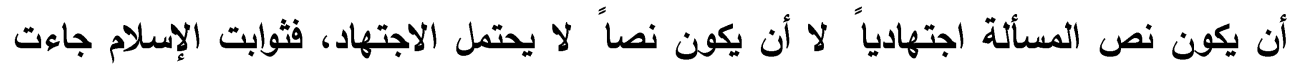

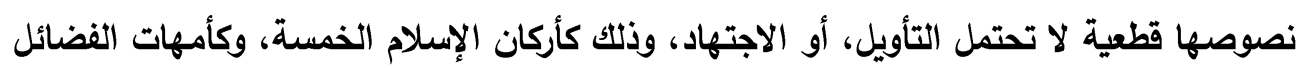

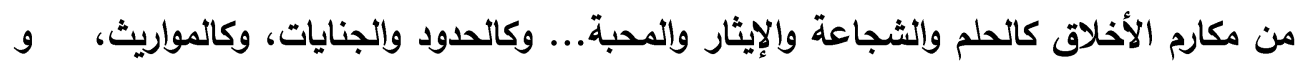

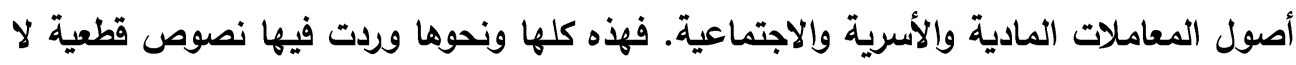
تحتمل الاجتهاد أو التغيير بحسب الزمان أو المكان.. فلا يجوز أن يقال بتغيير أحكام الحدود،

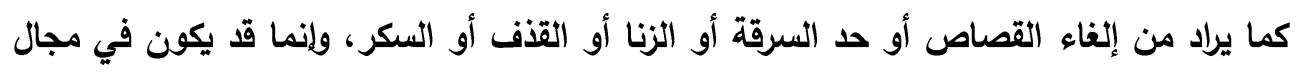

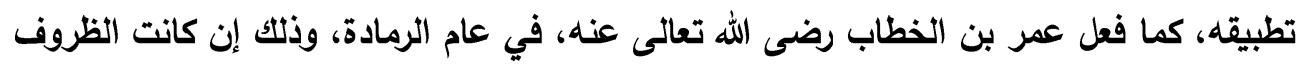


الحاصلة كمثل ذلك الظرف، من الضرر العام كما قال رضى الله تعالى عنه: لا تقطع الأيدي في

عنق ولا عام سنة (1). وذلكك لأنًّ الضرورات تبيح المحظورات، كما اتفق العلماء على ذلك، ومن هنا ابن القيم رحمه الله

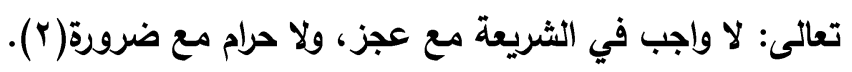

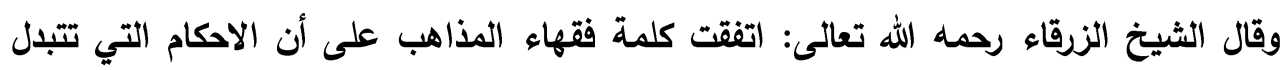

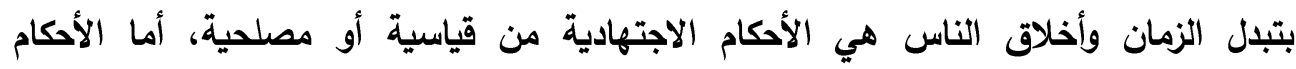

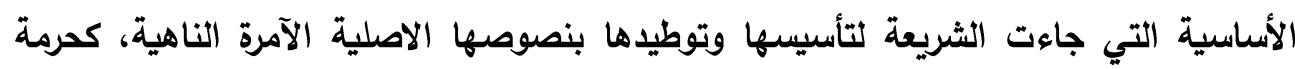

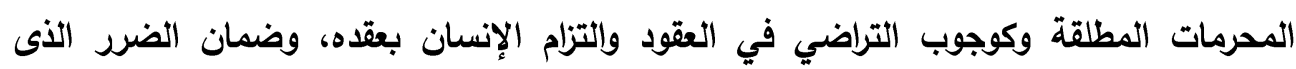

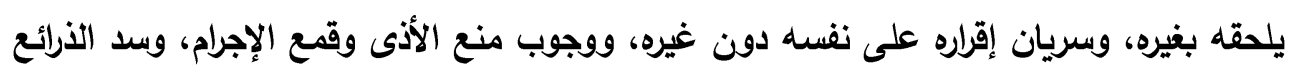

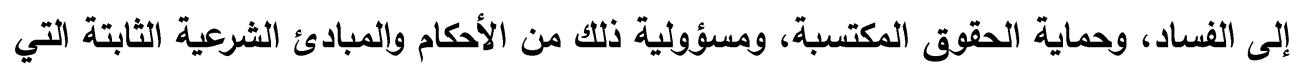

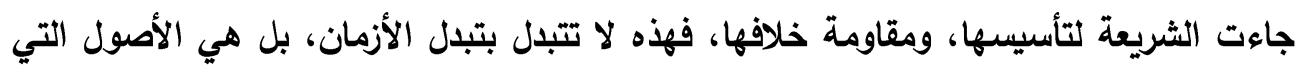

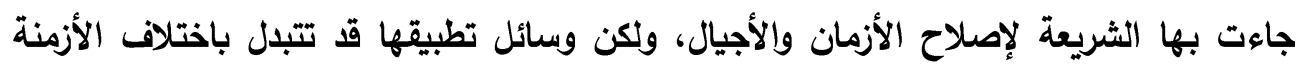

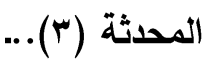
النوع الثاني: أحكام اجتهادية: فجميع الأحكام المبنية على اجتهاد الفقهاء تقبل التغيير، وهي

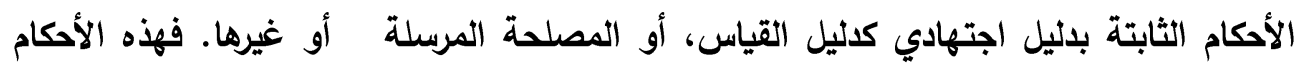

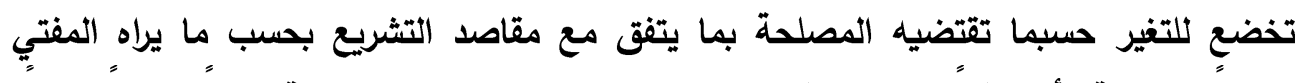

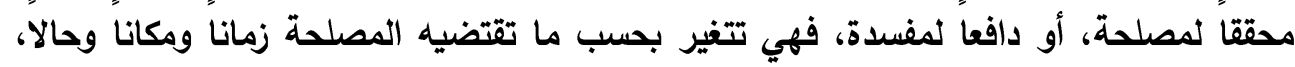

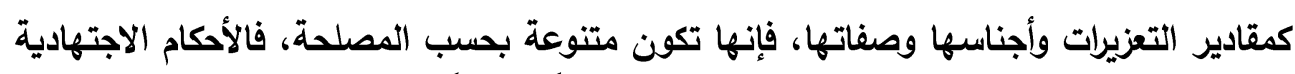

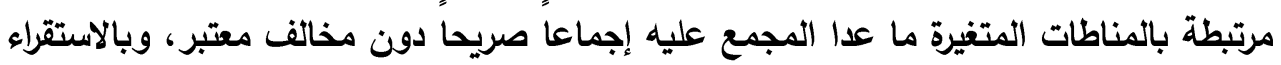

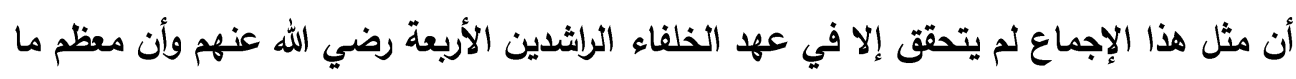

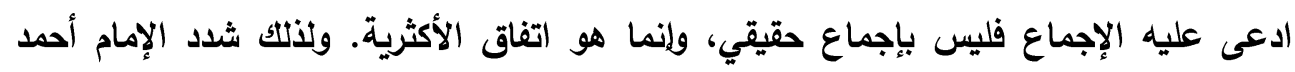
رحمه الله تعالى وقال: من ادعى الإجماع فهو كاذب. لإنيا

' - عزاه الحافظ ابن حجر في التلخيص الحبير: \& \& • V ليعقوب الجوزجاني في جامعه، ونقل

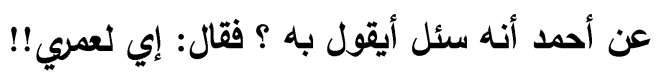

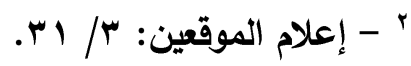

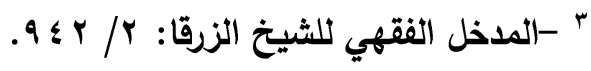




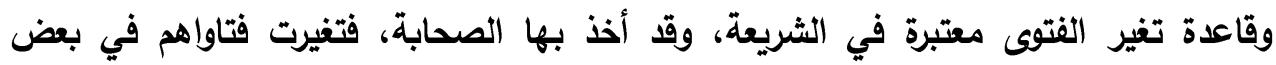

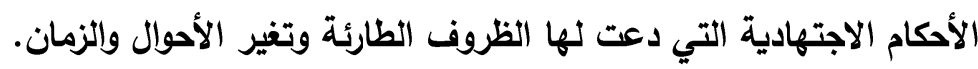

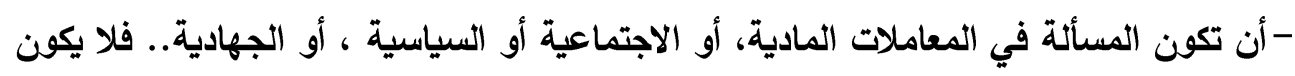
التغيير في العقائد، ولا في أمهات الفضائل. - أن يكون ذلك مما تخلتف فيه العوائد والأعراف، لا فيما تتفق فيهاته كما تقدم بيانه في أسباب

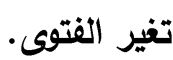
- أن تزول العلة التي قيد بها النص في الحكم الأول كقوله صلى الله عليه وسلم: " إنما نهيتكم

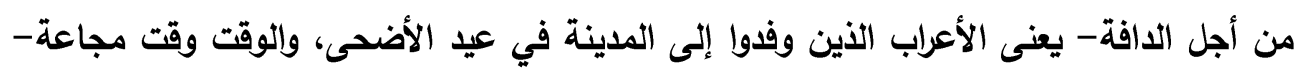

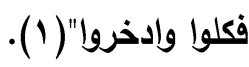

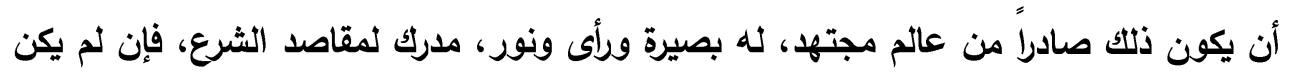

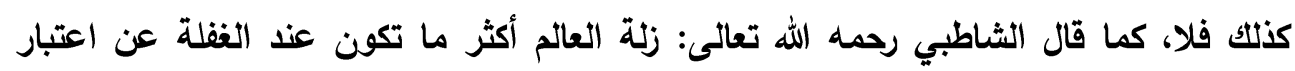

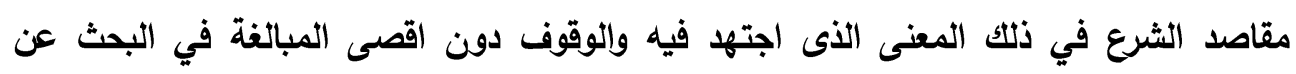

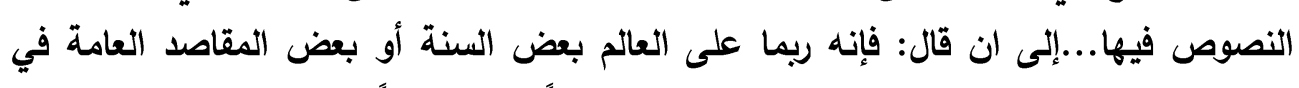

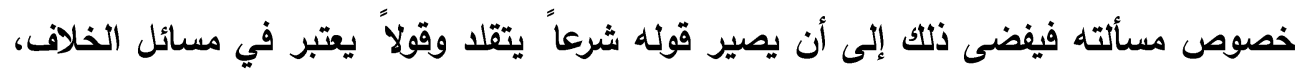

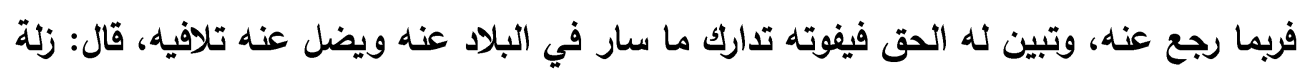

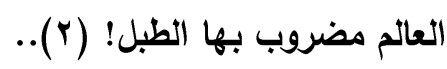
فإذا توفرت هذه الضوابط فلا مانع من القول بتغير الفتوى عند مقتضيات أسبابها المتقدمة؛ لأن

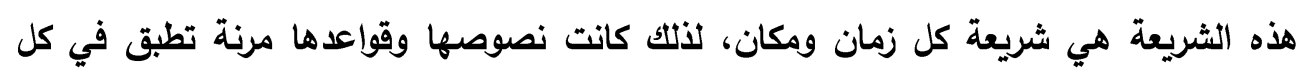
زمان ومكان، وفى كل حال من غير إخلال ولا إهمال.

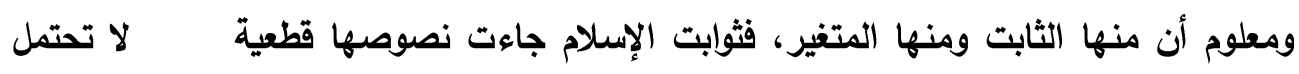

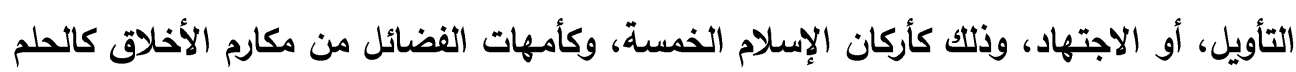

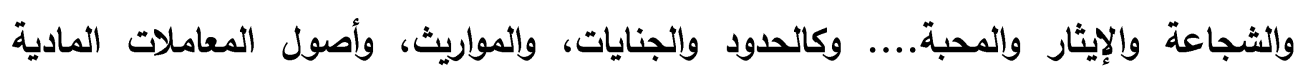
والأسرية والاجتماعية.

' - أخرجه مسلم في الأضاحي برقم: 19 ا من حليث عبد الله بن واقد الليثي رضي الله تعالى

\section{عنه.}

$$
\text { . IV • \& }
$$


فهذه كلها ونحوها وردت فيها نصوص قطعية لا تحتمل الاجتهاد أو التغيير بحسب الزمان أو أو

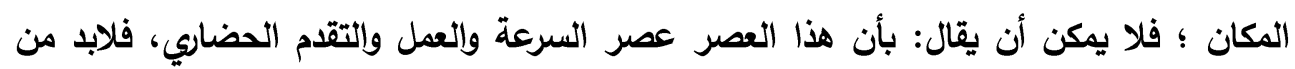

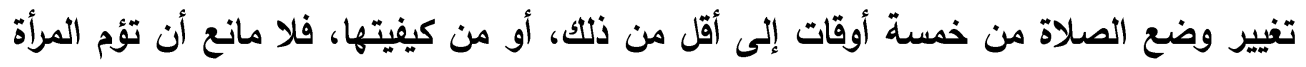

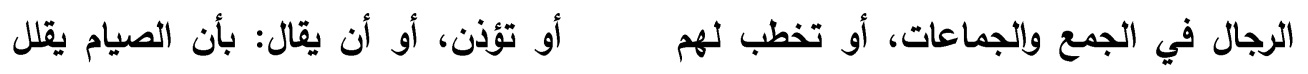

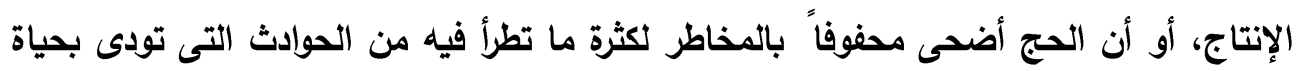
مئات الناس أحياناً ، فلابد من تغيير نسكه.. ولا أن يقال: إن هذا العصر عصر المصالح، فلا مجال لمن يتكرم بماله أو بأحسن أقواله وأفعاله، أفاله

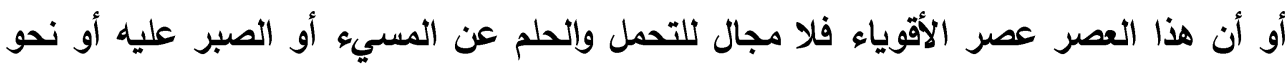

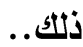

ولا أن يقال: إن المرأة اليوم أضحت كالرجل فى ميادين العمل ولهها من الحقوق المدنية

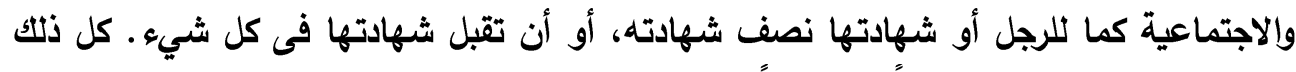

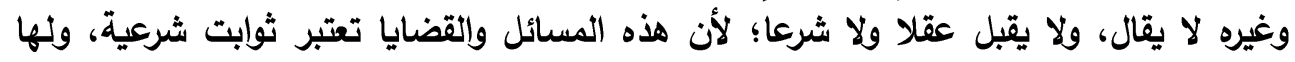
نصوص قطعية، فلا مجال لأن يتطرق الاجتهاد لتغيير كيفيتها ووضعها.. سواء أدرك العان العقل

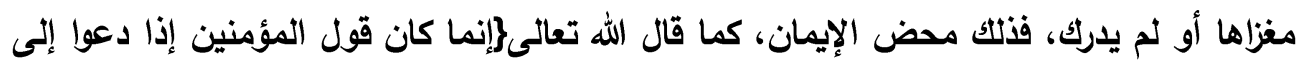

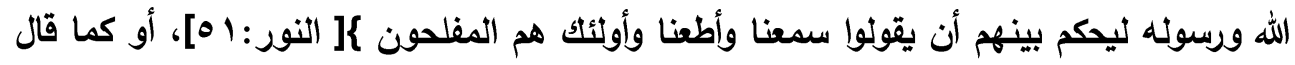

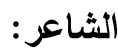

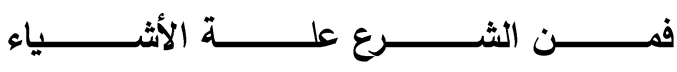

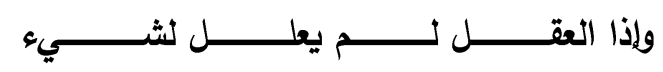

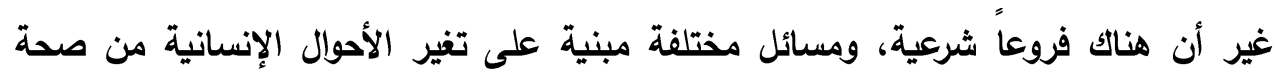
ومرض، وحضر وسفر ، وسعة وضرورة، ورخصة وعزيمة، واختيار وإكراه..

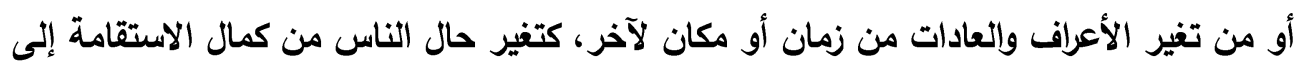

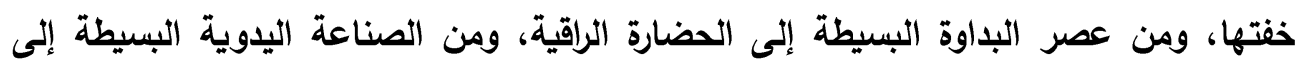

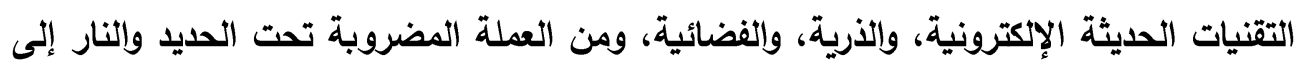

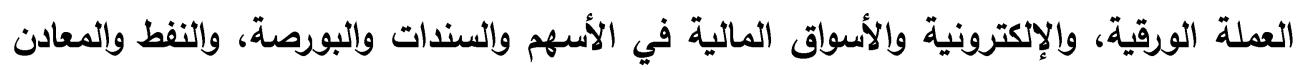
إلى غير ذلتك. كل هذه الأمور وغيرها يحمها الإسلام حكماً عادلا، ويتسع لاستيعابها، بل لإصلاح خللها ووضعها. 
فمثل هذه الأمور تختلف الفتوى فيها باختلاف الزمان والمكان، وهذا ما قره علماء الإسلام من تغير الفتوى بتفير الزمان والمكان، كما تقدم نقله وتقريره.

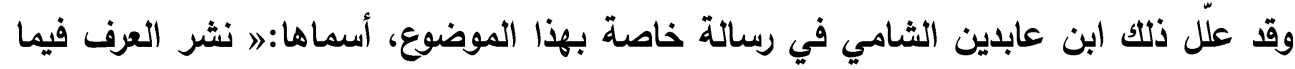

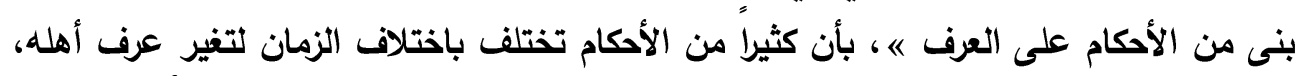

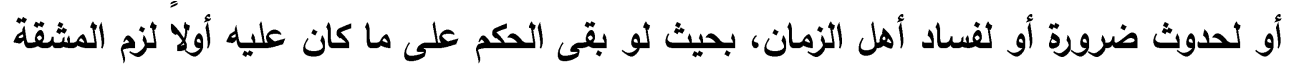

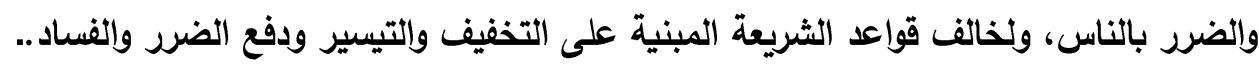
ويقولون بأن ذلك اختلاف عصر وزمان، لا اختلاف حجة وبرهان.

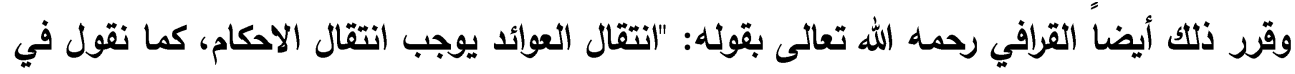
النقود وفى غيرها، فإنا نفتى في زمان معين بأن المشترى تلزمه سكة معينة من النقود عند النداف

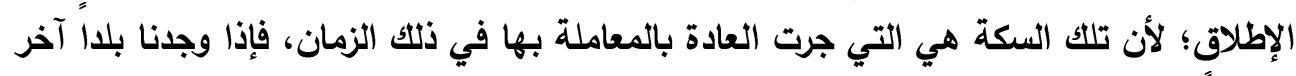

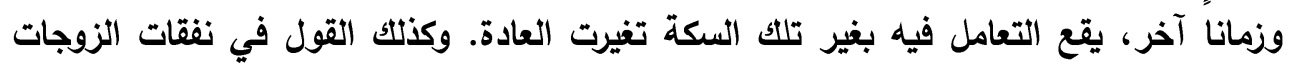
والذرية والأقارب وكسوتهم تختلف بحسب العوائد وتنتقل الفتوى بها، وتحرم الفتوى بغير العادة

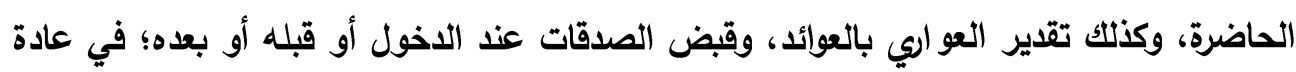

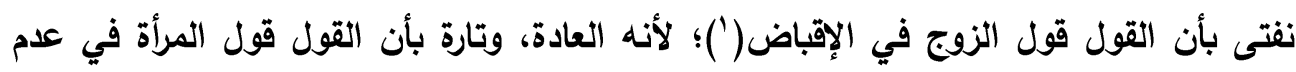
القبض إذا تغيرت العادة، أو كانوا من أهل بلد ذلك عادتهم، وتحرم الفتيا بغيرها.

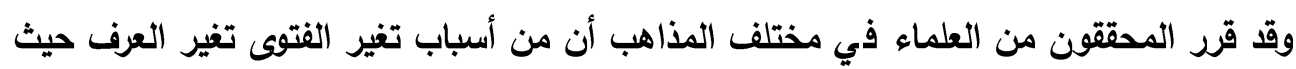

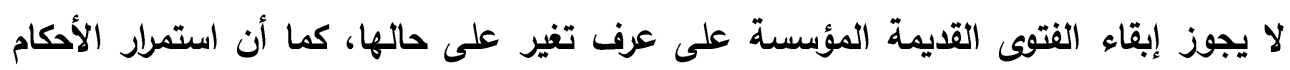

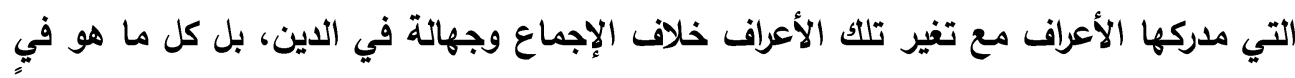

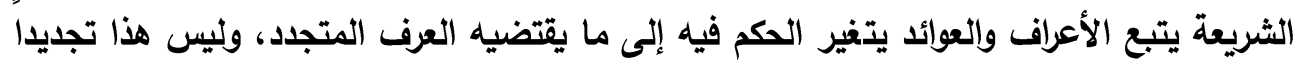

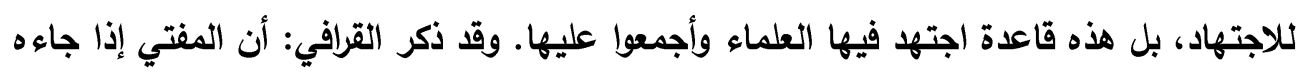

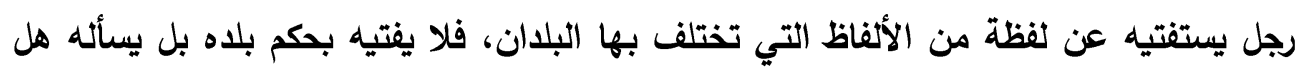

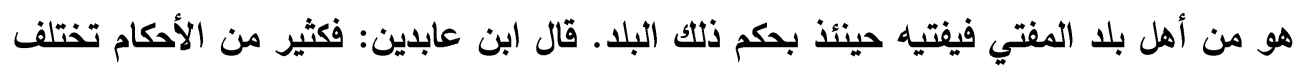

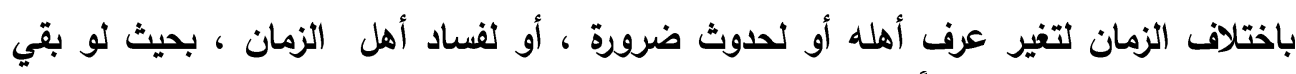

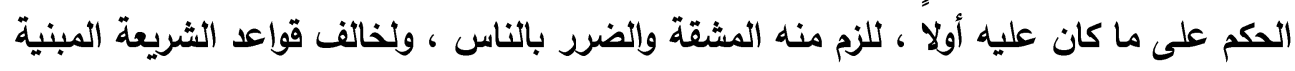

I - ينظر أنوار البروق في أنواع الفروق للقرافي / 


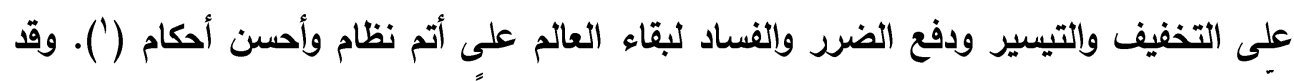

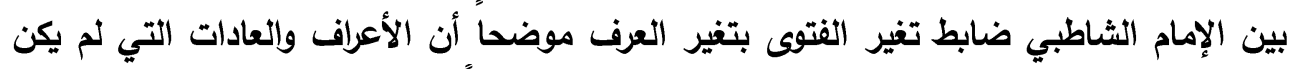

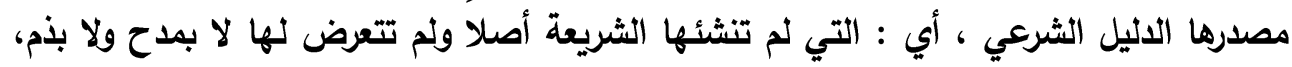

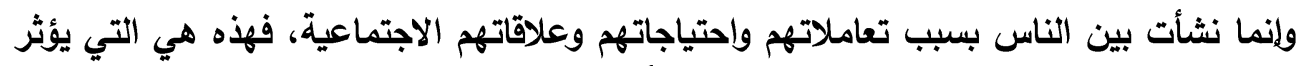

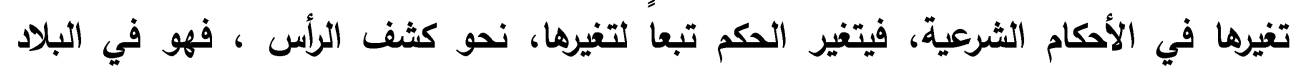
المشرقية في زمن الثاطبي قبيح لذوي المرويات بينما هو غير قبيح في البلاد المغربية ، والدكم

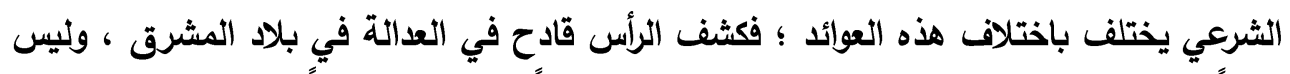

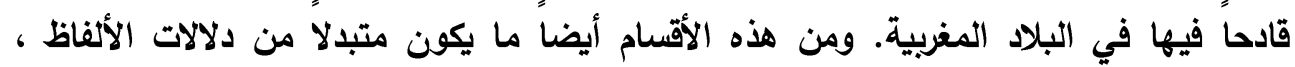

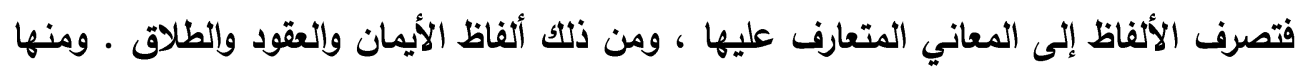

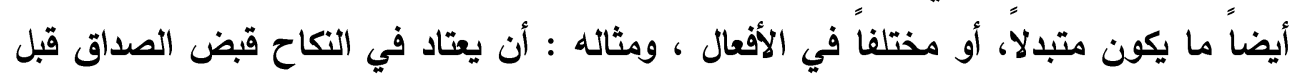

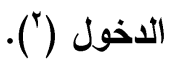

وقد نقل القرافي عن مالك قوله : إذا تنازع الزوجان في قبض الصداق بعد الدخول، فالقول قول

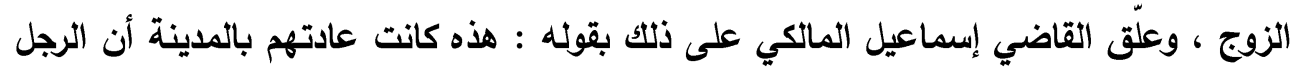

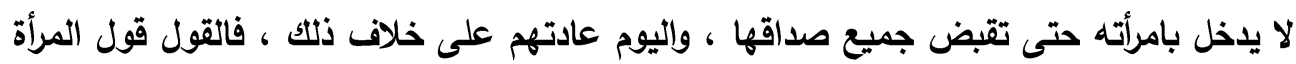

مع يمينها لأجل اختلاف العوائد (").

ومن هذه الأقسام أيضاً ما يكون مختلفاً وأما الأعراف التي اعتبرتها الثريعة من المحاسن وأقرتها

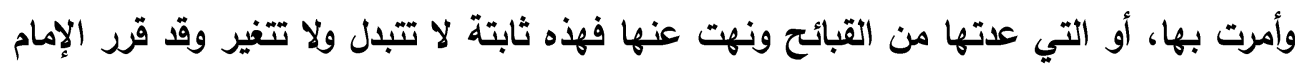
ابن القيم أن تغير الفتوى المشروط يبنى على ركنين هما: - رعاية الثريعة للمصالح ودرء المفاسد في المعاش والمعاد لأن الثريعة أساسها ومبناها على لمانى هذا الأمر. - بناء المصلحة على الثريعة وليس العكس، إذ يجعلها الأصل والمرجع في تقرير ما هي

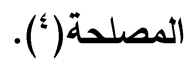

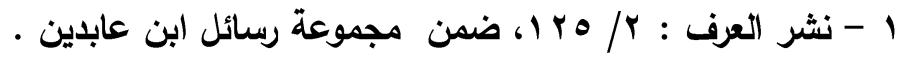

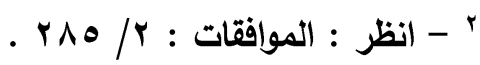

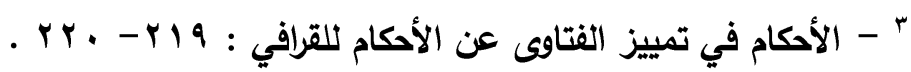

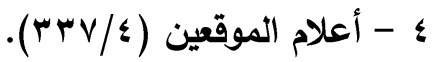


وفي ضوء ما تقدم يتقرر أن الأحكام الثابتة بناء على النص لا تتغير أحكامها، لأن النص أقوى

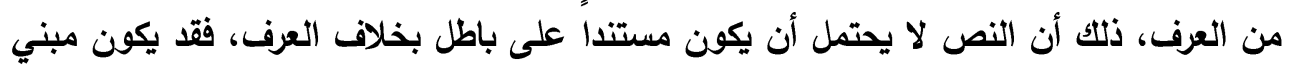

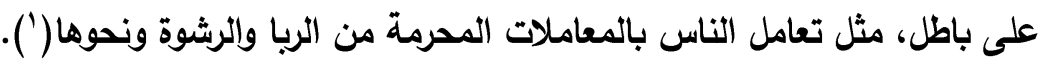

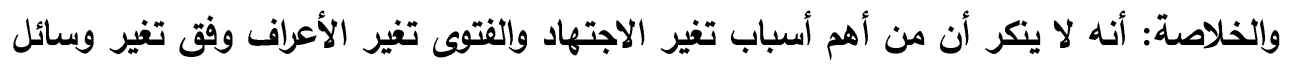

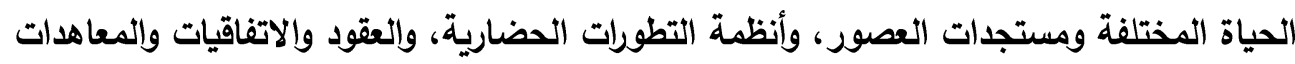
التي تفرض على المجته التصدي لها باجتهاد جديد، لا يصادم النصوص الشرعية، ولا يخرج عن ولنهات

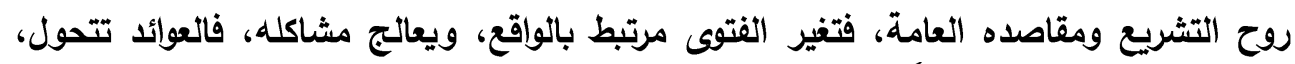

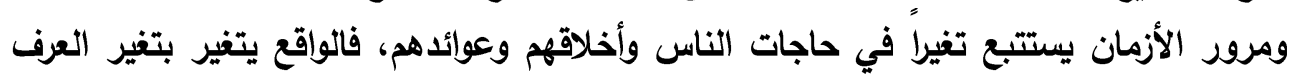

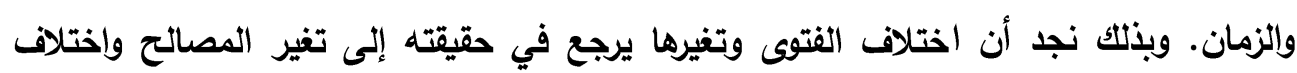
المناط وتحقيقه في الواقعة، وتغير طبيعة المحل، وبتغير المناط تتغير الفتوى ونئ.

1 - أنظر: درر الحكام/ علي حيدر : 1 ؛ . 


\section{الانمصل الثاني}

الفرق بين مصطلح تغير الفتوى، ومصطلح تغير الأحكام

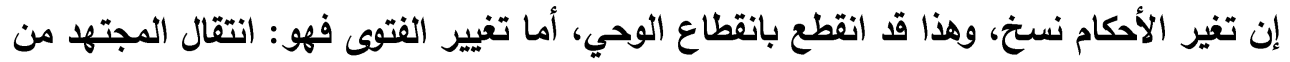

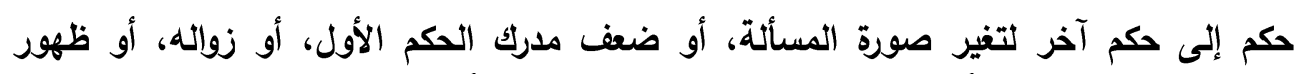

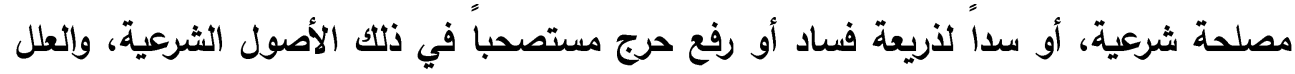

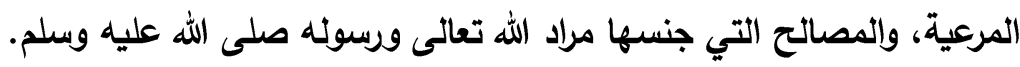

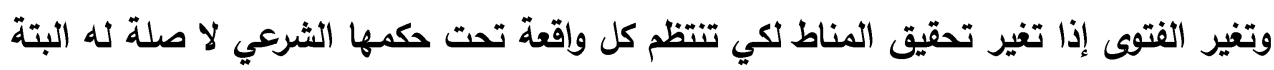

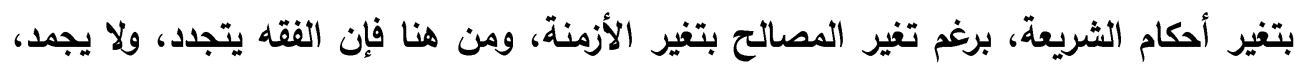

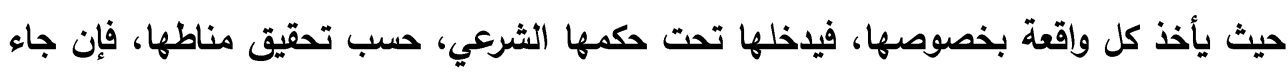

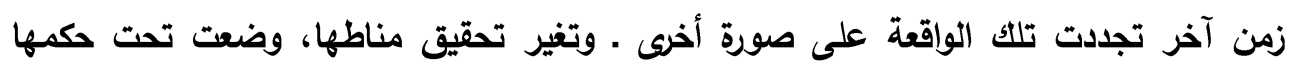

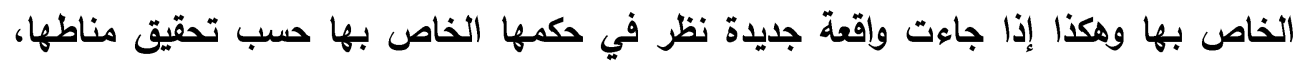

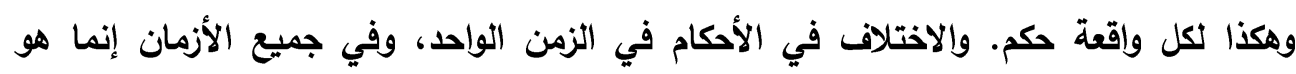

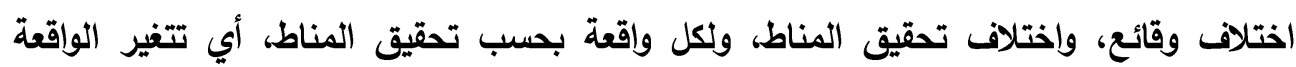
فيدخلها الفقه حيئذ تحت حكم يخصهاب(1). 


\section{الابمش الأول}

\section{تنظير القول بتغير الأحكام}

إن إطلاق القول بأنه: لا ينكر تغير الأحكام بتغير الأزمان أمر فيه نظر: فإن الحكم الثرعي

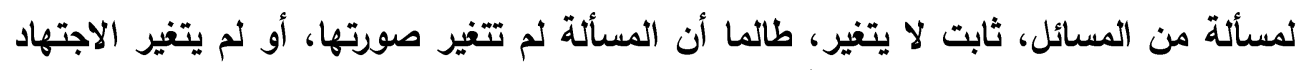

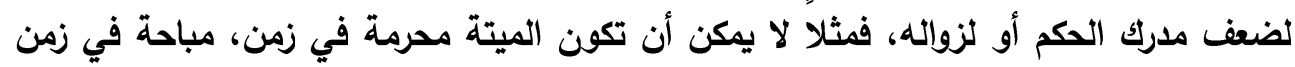

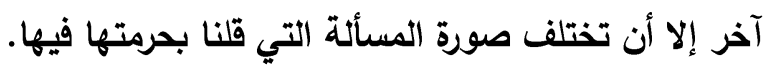

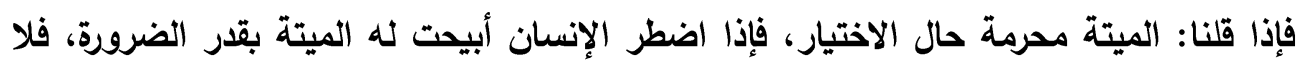

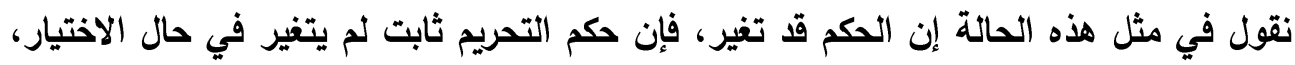

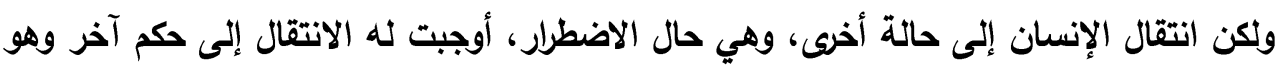

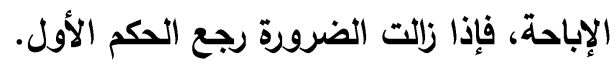

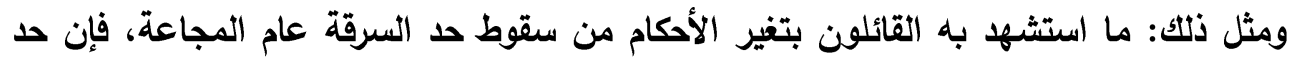

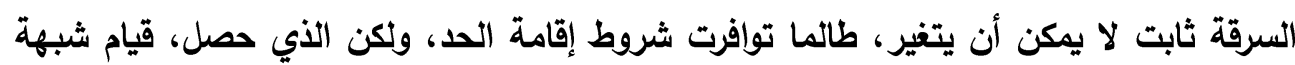

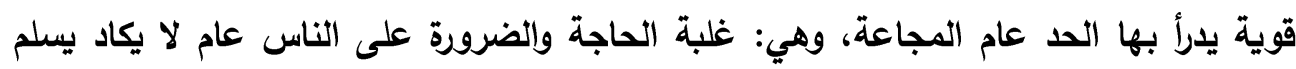

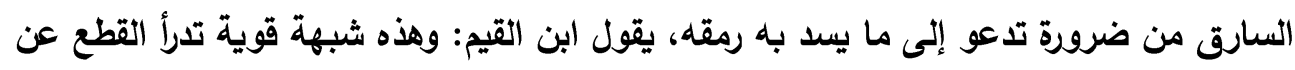

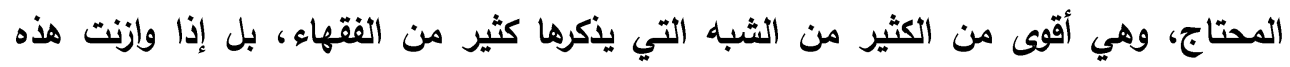

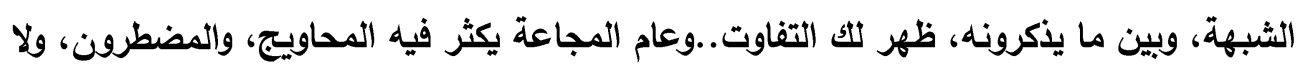

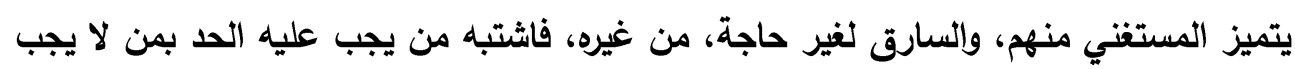
عليه فدرئ ('). إذا فحكم القطع باق حتى في عام المجاعة لمن توفرت فيه الثروط، ولهذا قال ابن القيم: نعم إذا

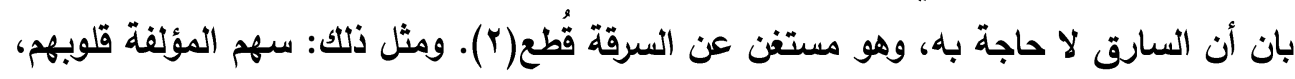

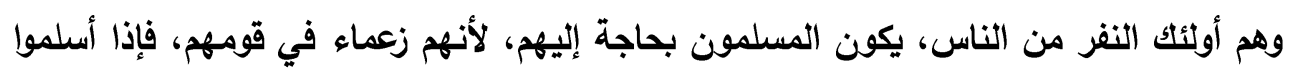

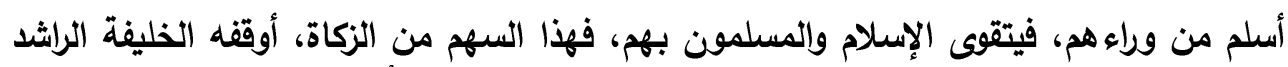

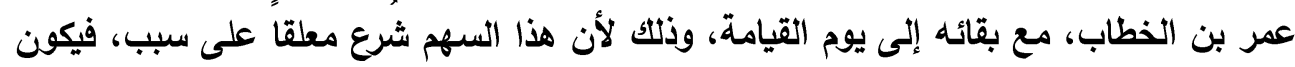

$$
\begin{aligned}
& \text { ' - إعلام الموقعين: r/ }
\end{aligned}
$$

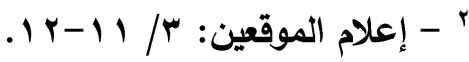


مشروعاً عند وجود ذلك السبب، ولما لم تكن الحاجة في عهر عمر قائمة إلى التأليف، ترك إعطاء المؤلفة قلوبهر ـ وهذا معنى قول عمر رضي الله عنه: إن رسول الله صلى الله عليه وسلم

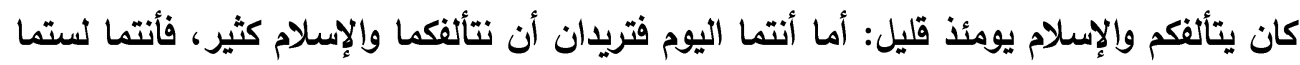
من المؤلفة قلوبهم اليوم، ولن كنتم منهم من قبل، وهذا من عمر هو الفقه، وهو ما يسميه الأصوليون (بتحقيق المناط). فالحكم المشروع على سبب يدور معله وجوداً وعدماً (فالأحكام ثابتة تتبع أسبابها حيث كانت بإطلاق) فالحاصل أن الحرام في كتاب الله وسنة رسوله صلى الله عليه وسلم حرام إلى يوم القيامة، والحلال في كتاب الله وسنة رسوله صلى الله عليه وسلم حلال إلى يوم القيامة، لا يمكن لأحد تبليله، ولا تغييره كائنا من كان، وفي ذلك يقول عمربن عبد العزيز رحمه الله تعالى:(أيها الناس وله

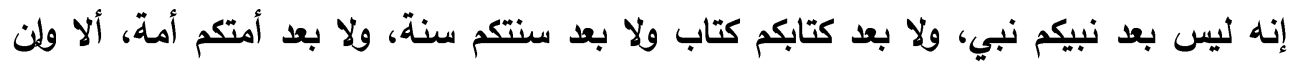

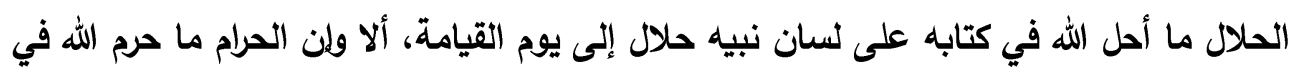
كتابه على لسان نبيه صلى الله عليه وسلم حرام إلى يوم القيامة).

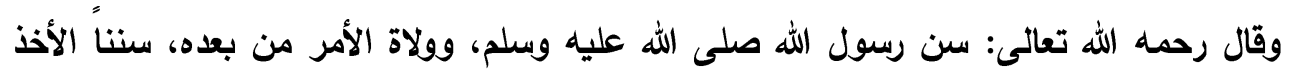
بها، تصديق لكتاب الله، واستكمال لطاعة الله، وقوة على دين الله، ليس لأحد تغييرها ولا تبديلها،

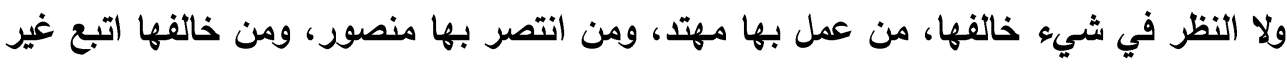

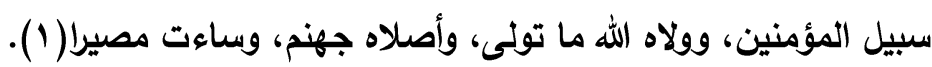
وقد ذكر الثاطبي رحمه الله تعالى أن كلام عمر بن عبد العزيز الآنف الأكر، اعتنى به العلهاء جلهاء

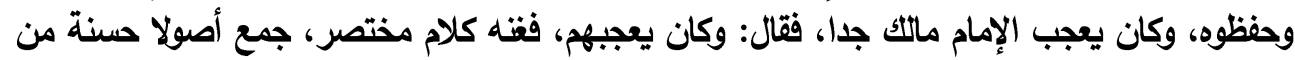

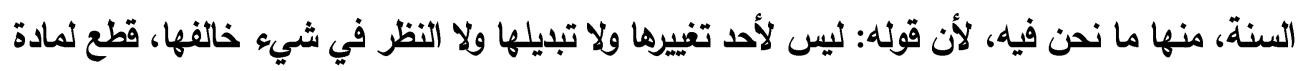

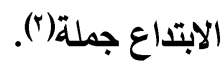

' - الاعتصام: / / V /. وقد ذكره الإمام مالك عن عمر بن عبد العزيز كما في كتاب الجامع في

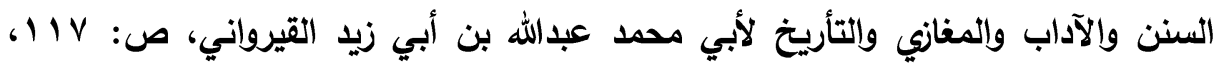

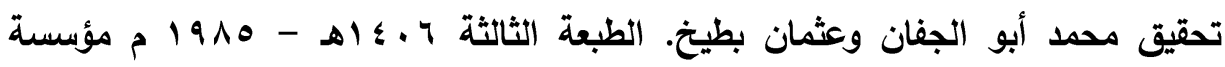

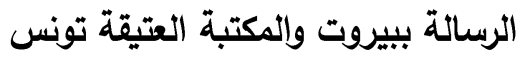

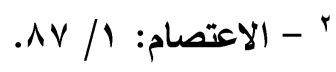




\section{口المبمث الثاني}

\section{مراد العلماء الذين أطلقوا القول بتفير الأحكام}

حينما يطلق العلماء من سلفنا الصالح القول بتغير الأحكام، فإنهم يعنون ما قررناه آنفا، وهذا

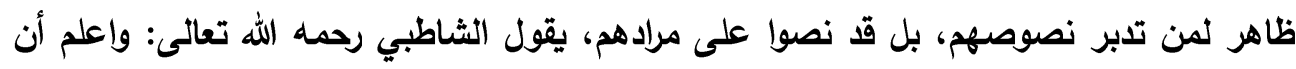

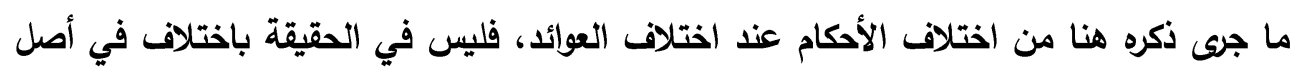

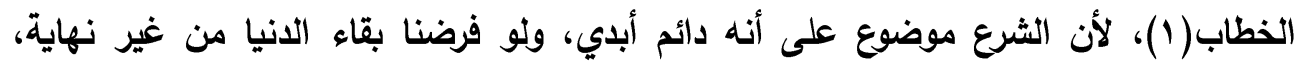

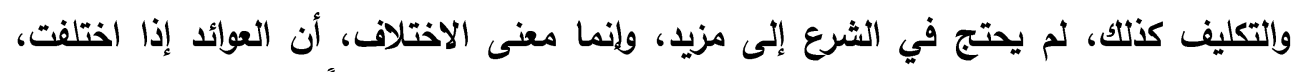

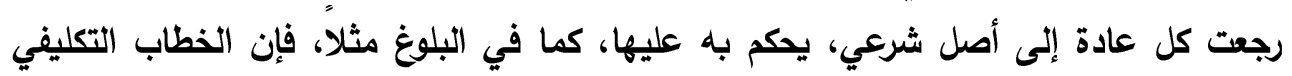

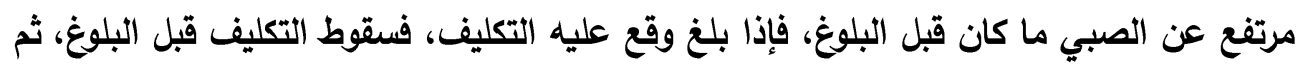

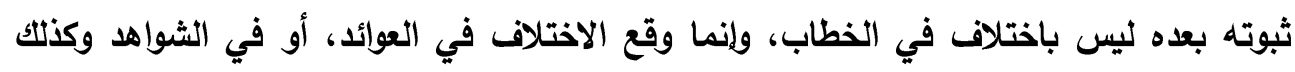

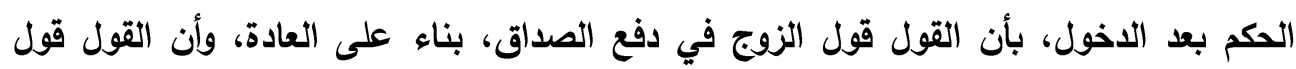

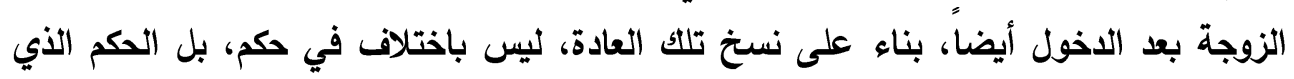

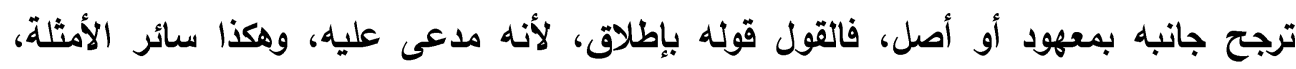

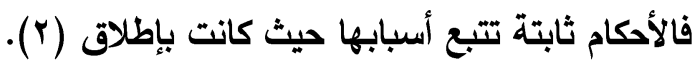

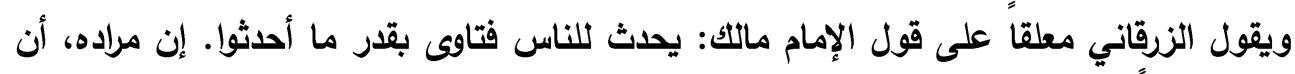

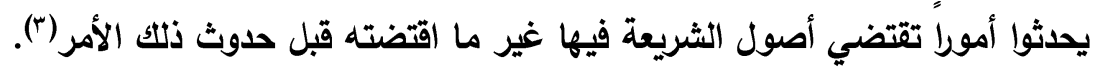

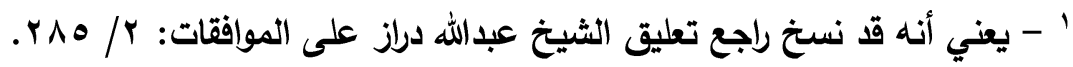

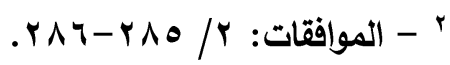

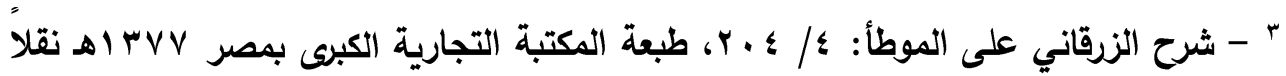

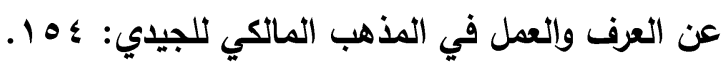




\section{المبمث الثالث}

مراعاة تغير الفتوى الاجتهادية بتغير الزمان والمكان والأعراف

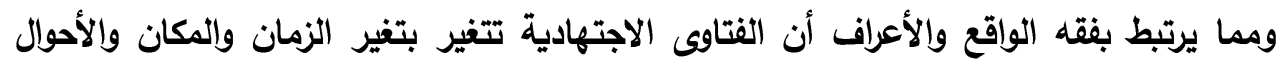

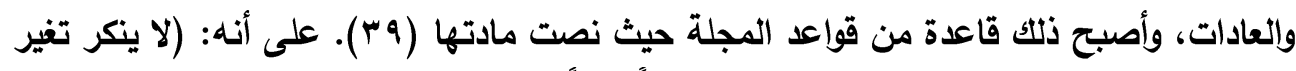

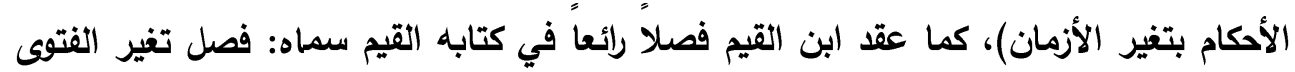
واختلافها بحسب تغير الأزمنة والأمكنة والأحوال والنيات والتعوائد.

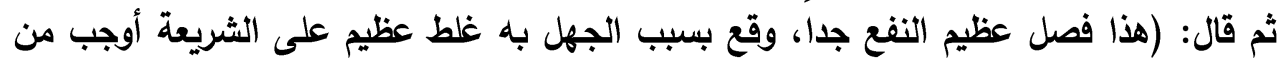

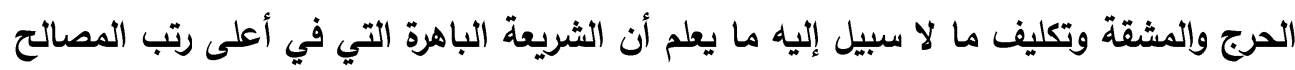

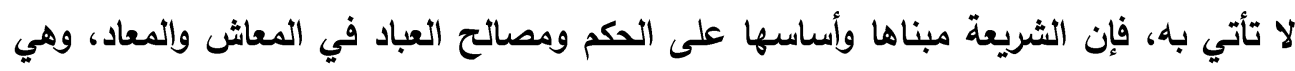

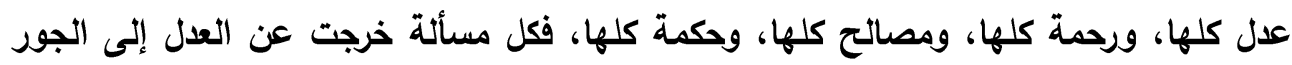

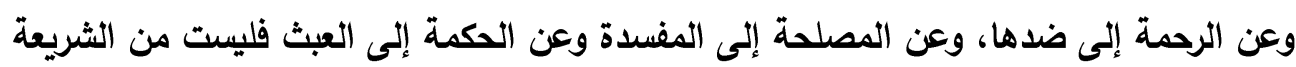
وان أدخلت فيها بالتأويل.

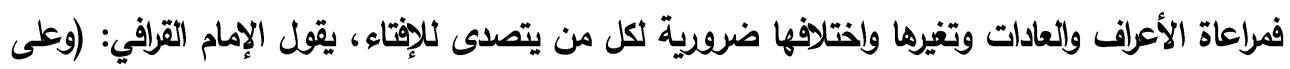

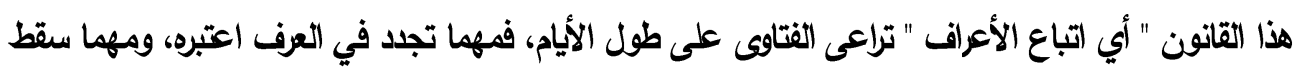

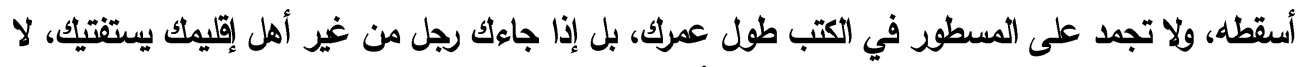

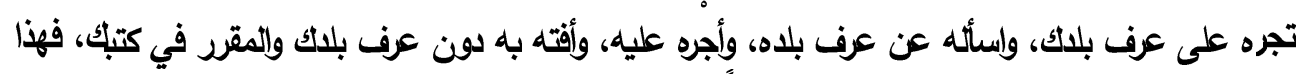

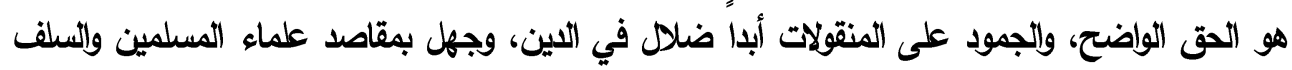

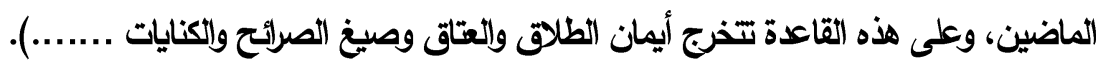

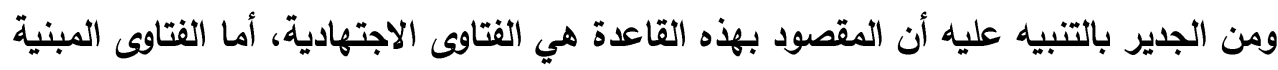

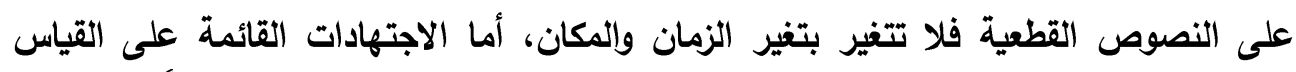

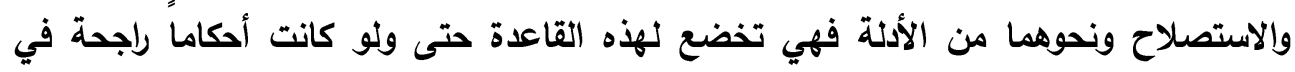

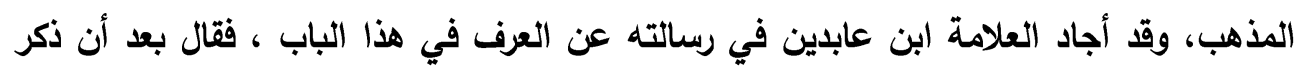

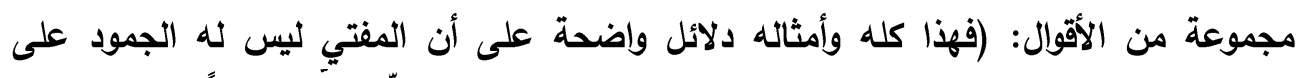

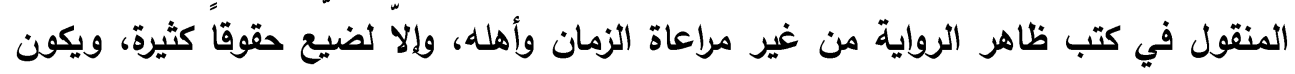


ضرره أكثر من نفعه.) ثم قال: (وبما قررناه اتضح للك معنى ما قاله في القنية ... من أنه ليس

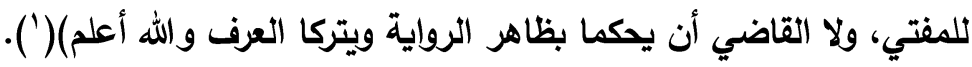

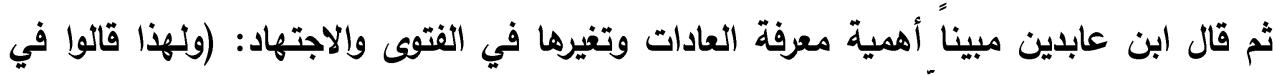

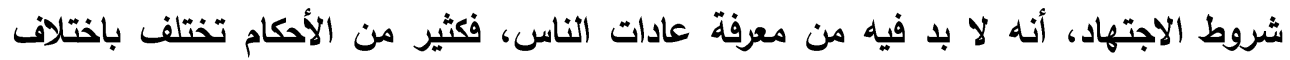

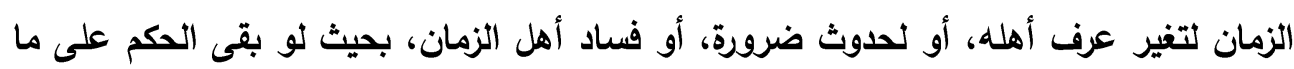

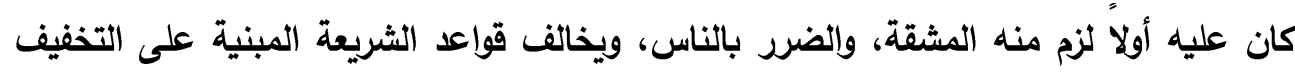

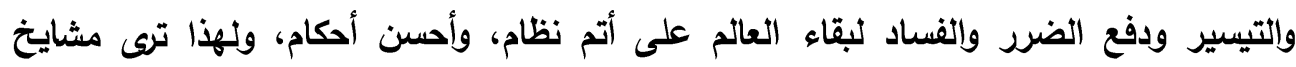

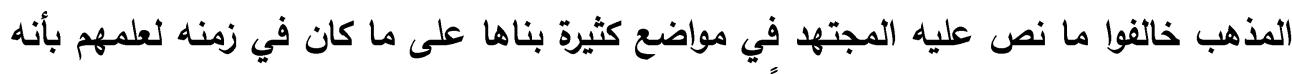

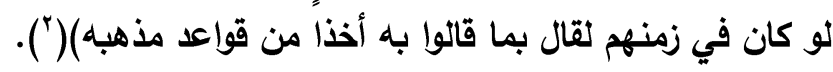
من الذي يتولى تغيير الفتوى؟: مما يعلم أن الفتوى لا تصدر إلا ممن له الاجتهر الأهاد فيما سئل عنه، وهذا بناء على أن الاجتهاد

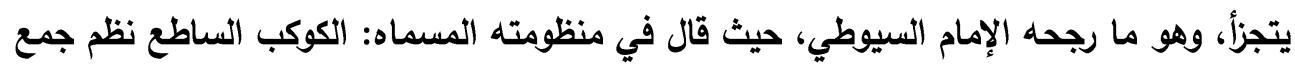
الجوامع: والمرتضى تجزئ الاجتهاد(").

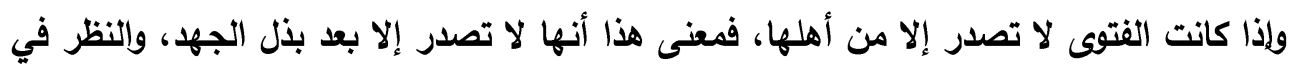

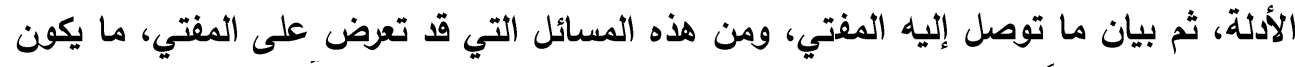

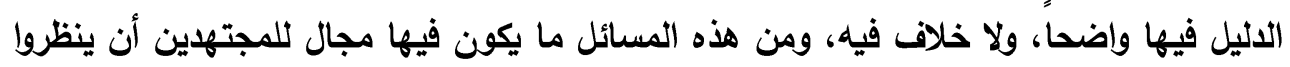
في الثواهد والقرائن والثقياس، حتى يصلوا إلى حكم فيما سئلوا عنه. ولقد ضبط الفقهاء مسألة تغير الفتوى بضوابط محددة لا يعلمها إلا طائفة مخصوصة، وهئ وهم علماء الشريعة الإسلامية، وهم ورثة الأنبياء والموقعون عن وبط لفيط العالمين - حتى لا يفتح الباب

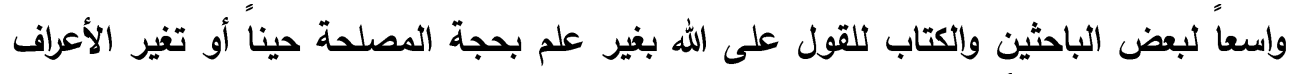

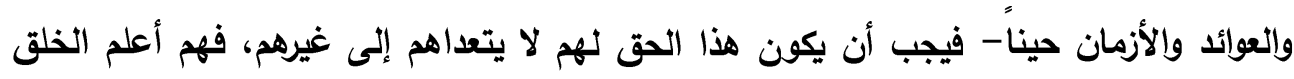
بعد نبي الله صلى الله عليه وسلم بالله وبمراد الله تعالى يعرفون الأمور، ويعرفون المصالح

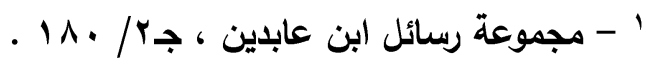

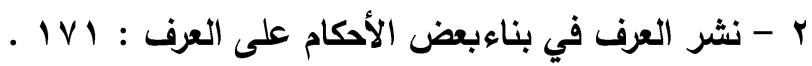

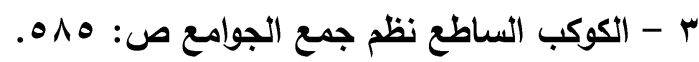




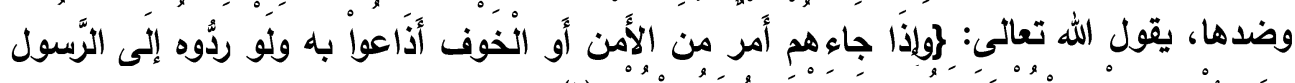

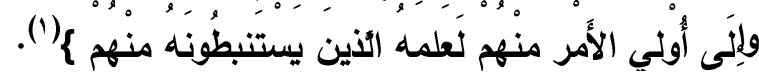

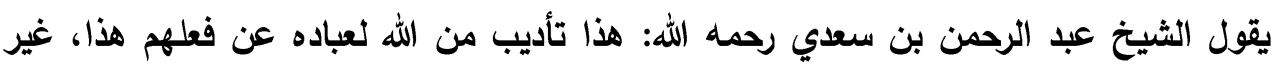

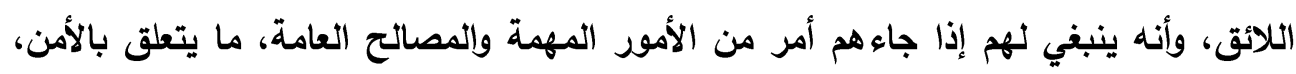

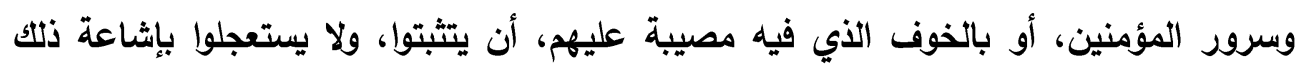

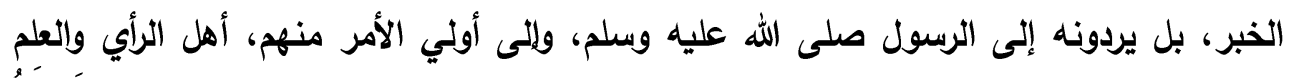

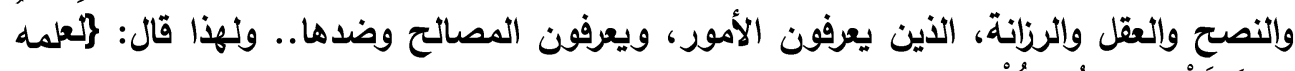

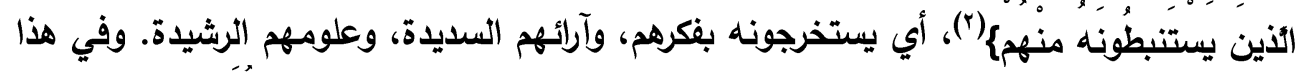

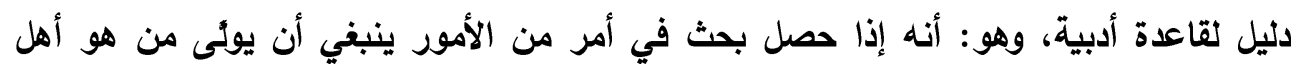

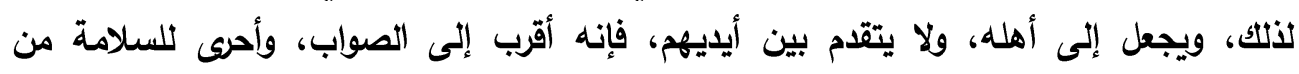

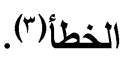
لهذٍا نجد العلماء قد اشترطوا فيمن يتولى الفتوى (أن يكون مسلماً، عدلاً، مكلفاً فقيهاً، مجتهاً،

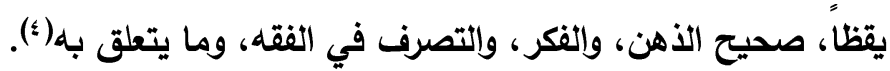

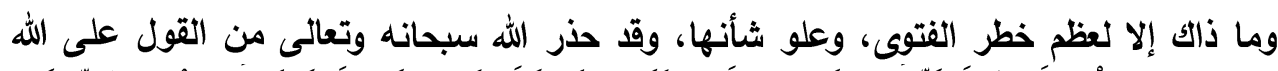

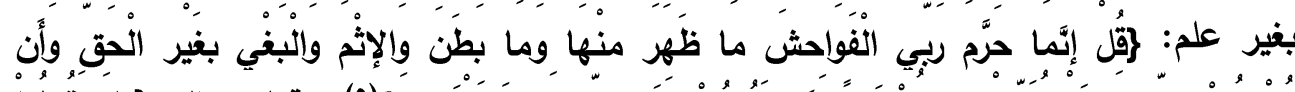

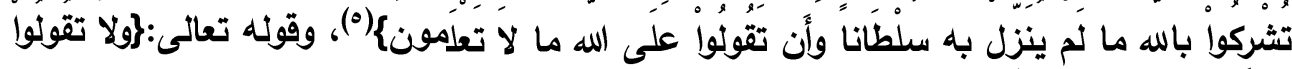

r - سورة النساء، الآية: س ^.

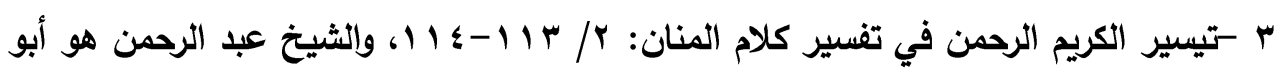

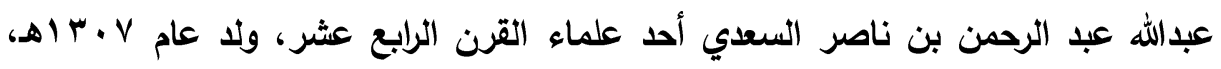

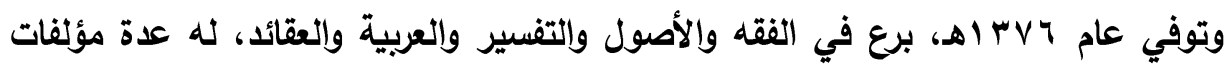

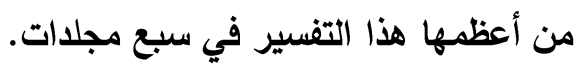

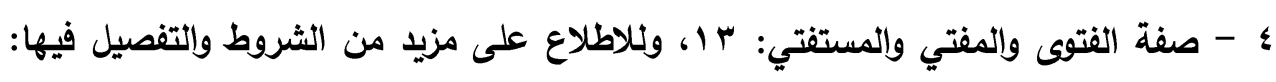

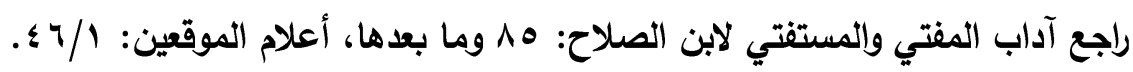

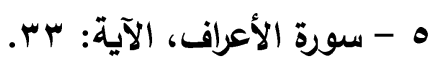




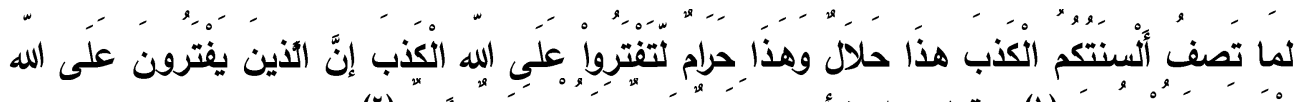

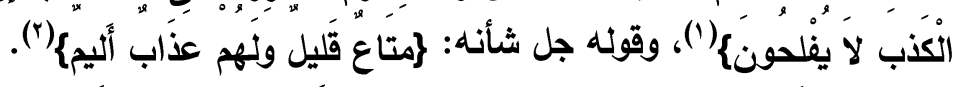

1 - سورة النحل، الآية: 117 - 11.

r - سورة النحل، الآية: 11V 


\section{المبحث الفظامس \\ ماهية تغير الفتوى اهني}

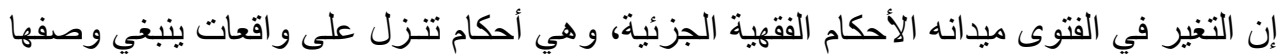

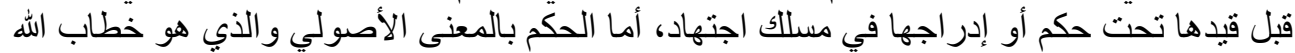

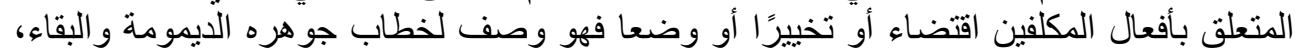

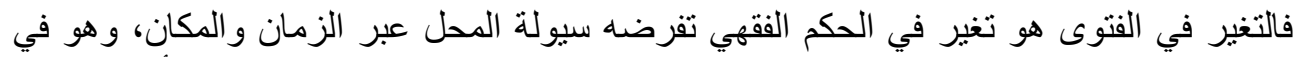

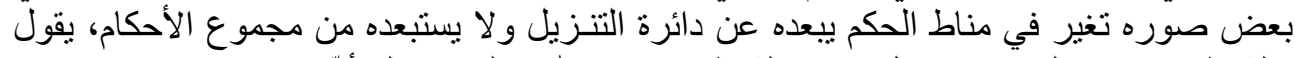

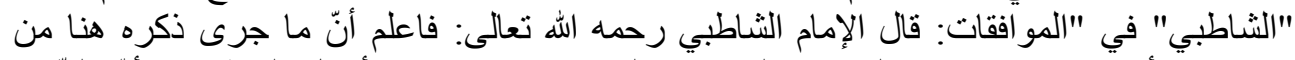

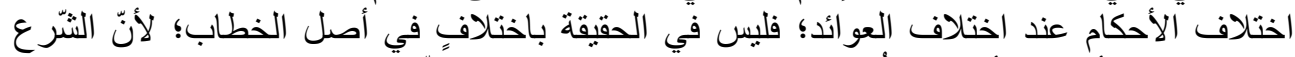

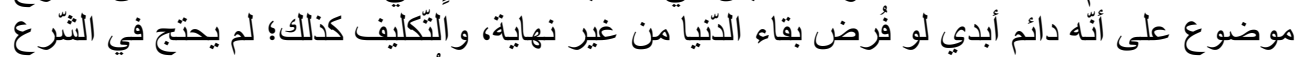

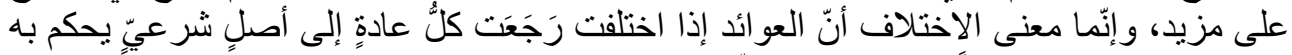

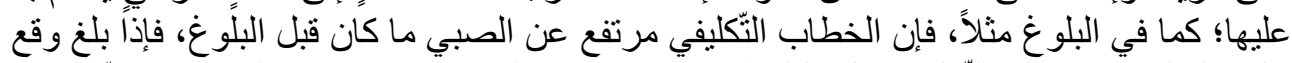

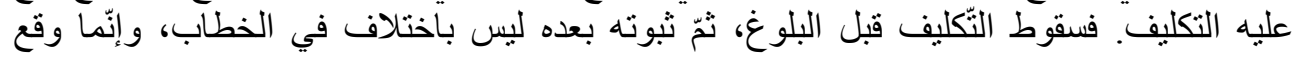
الاختلاف في العو ائد و الثثو اهد)(' (')..

و الحقيقة كما يقول العلامة"مططفى الز رقا" - أن الأحكام الـدر عية التي تتبلل بتبديل الزملنمهاتغيرت بتغيره، فإن المبدأ الشرعي فيها و احدوماتبل الأككام إلالتبل الوسللى والأساليب الموصلة إلى غاية الثدرع، فإن الك الوسلل والأساليب في الغلب لم تحددها الـ رد يعة الإسلاميةلكي يختار منها فيكل زملنما هو أصلح

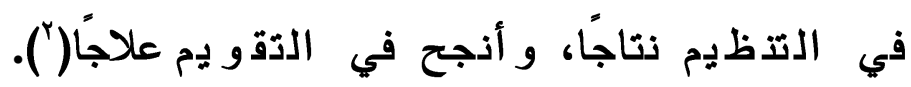

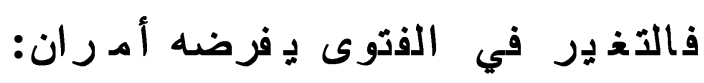

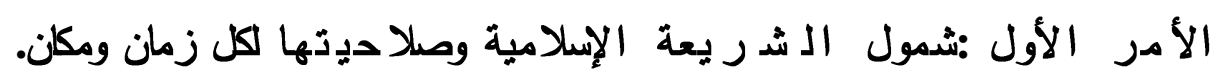
الأمر الداني نتجدد الوقائع في زمن القادم فيهمجهول،لأن المستقبل في عالم

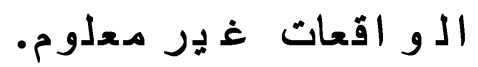

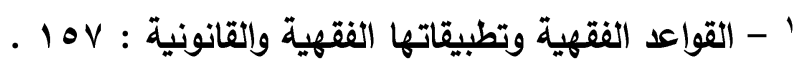

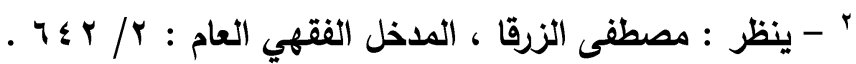




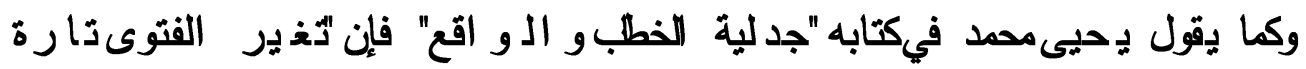

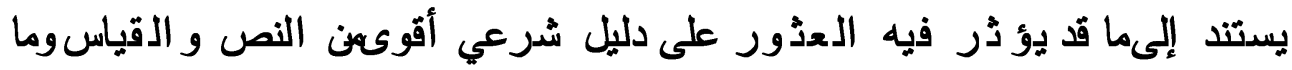

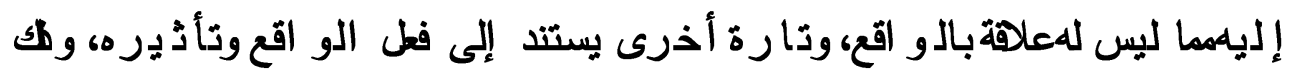

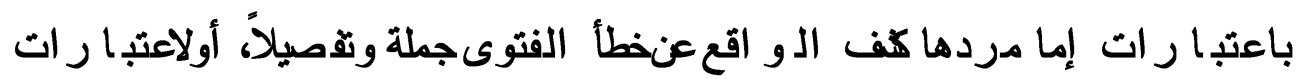

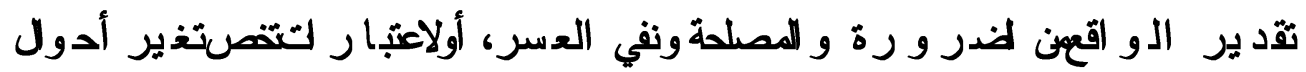

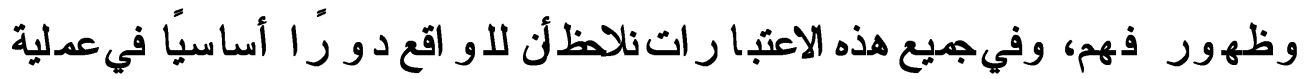

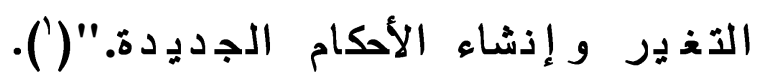

1 - مجلة البحوث الفقهية : التفير في الفتوى ( الانماط والعوامل : 1. 


\section{|الفnل الثالث}

\section{الأسباب المؤدية إلى تغير الفتوى}

مما يُلم أن الفتوىلاتصددر إلاممن له الاجتهاد فيما سئل عنه، و هذ ذا بـاء على أن الاجتهاد يتجزأ، و هوما رجحه الإمام السديوطي، حيث قال في منظومته المسماه: الكوكب الساطع ذظم جمع الج و امع: و الـرتضى تجزئ الاجتهاد (1). و إذاكانت الفتوىلاتصددر إلامن أهلها، فمعنى هذ ذا أذهالاتصددر إلا بعد بذل وهي الجهد، و الذظر في الأللة، ثُ بيانماتوصل إليه المفتي،ومن هذه المسللى التي قد

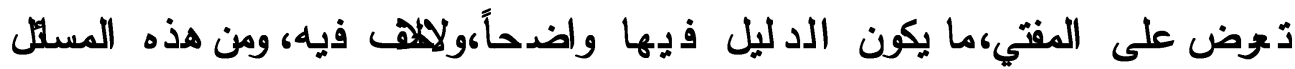

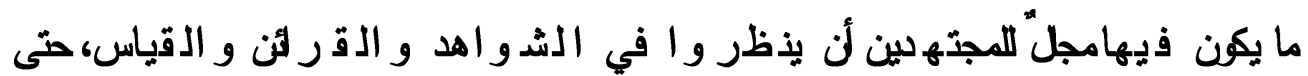

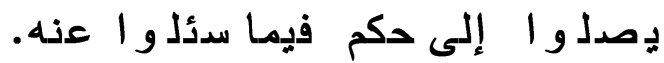

وإن سلفنا الصالح - رحمهم اللهتعالى - قد لمضدو ا ذفيس أوقاتهم وجل أعدار هم في التأصيل و التفريع،خمة له ذا الدين وامتلالتّو جيه رب العلامين، بقوله تعالى:

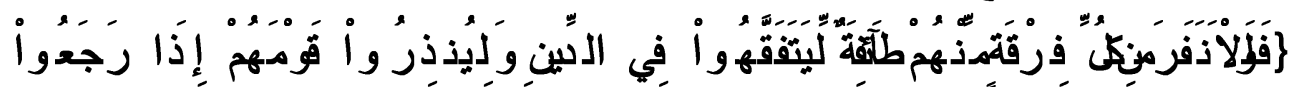

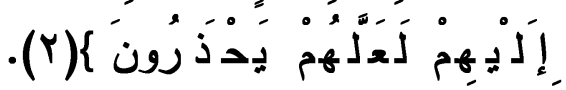
فكانمن نتاج الك ذُر وة فق هيةمن الأصول و الفروع، صدارت لمن بعدهم بمذابة

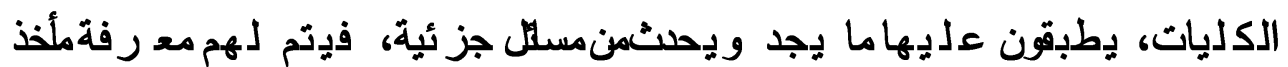
الصدور- فإن أهل العلم رحمهم اللهوجزاهمعن المسلمينخير الجزاء-قصدوا في كماتهم المحكة الكلية أن ذحيط بجميع ما بحدثم الجزئيات ، و لـه ذالا يكاد

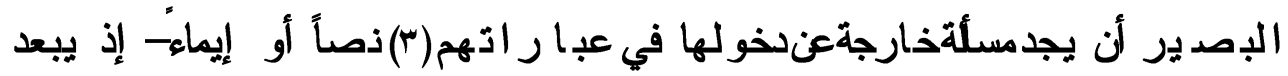

1 - الكوكب الساطع نظم جمع الجوامع ص: ه1 هـ.

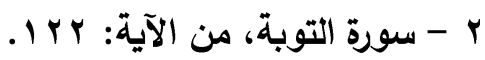

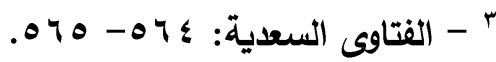


أن ثقع و اقعة لم ينص على هكمها في المنبهولاهي في معنى بض المنصوص

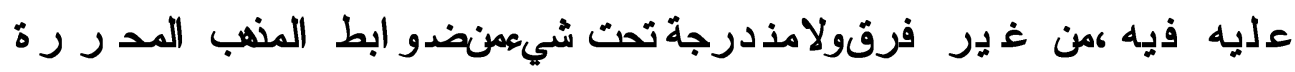

فيه (1).

ويجمعذذا قول الإمام الشافعي رحمه اللهتعالى: فليس تتزل بأحمن أفل لين الله

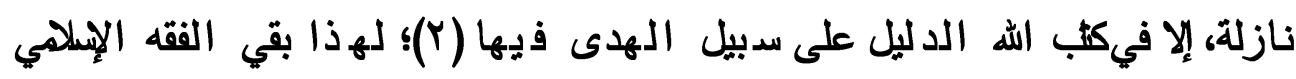

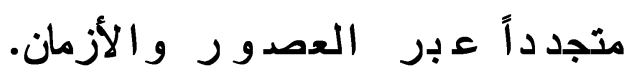

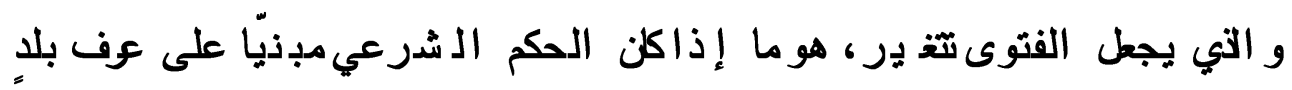

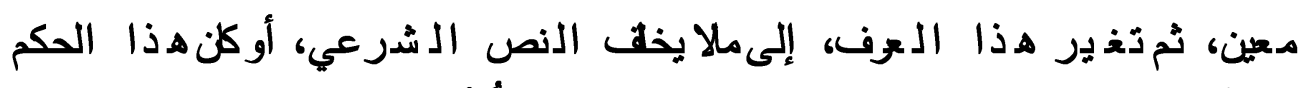

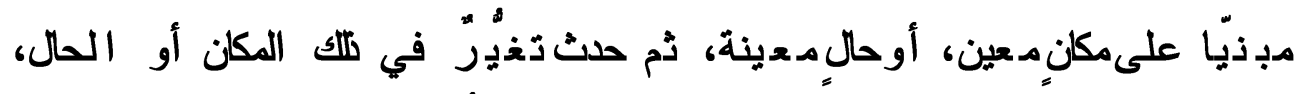

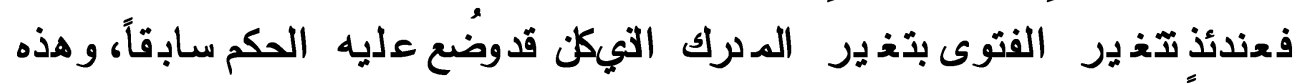

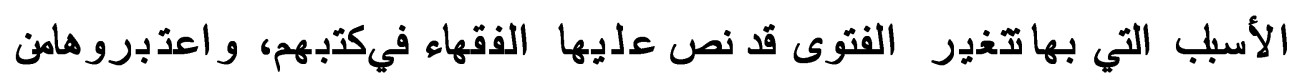

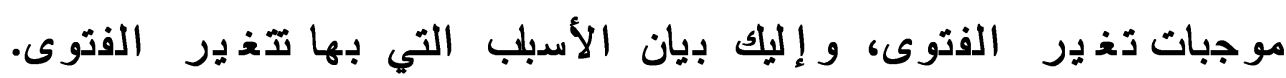

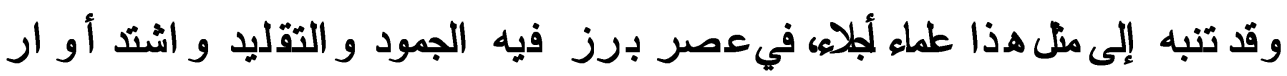

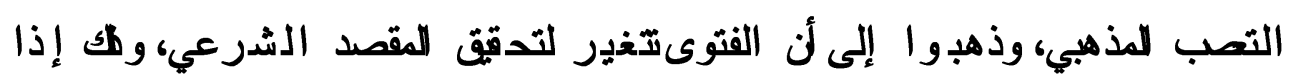
وجد سببمن الأسبلب التالية:

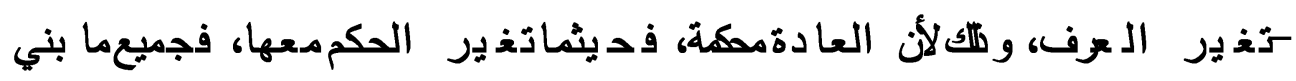

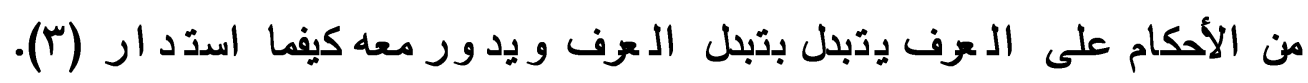

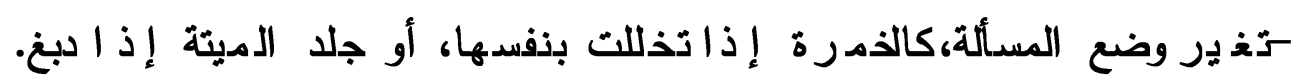

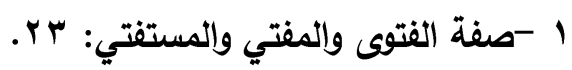

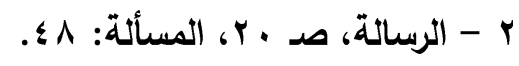

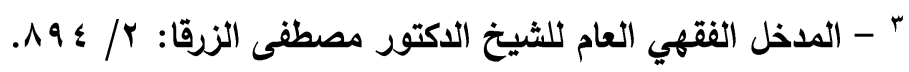


-حصول فهم جديد مستند لأللةمقبولةكما حث للإمام الشافعي رحمه الله تعالى في القديم و الجديد وما يحدث للمجتهد عذد البحث أو المناظرة.

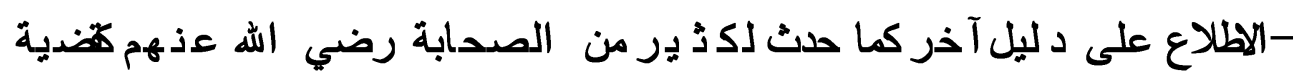
الاستئذذان و غ ير ها. كتغ ير الاجتهادكما فعل عمر بن الخطب رضي الله عنه في قضية الإخو ة لأممع الإخوة الأشقاء، حيثقضى فيها بقضائنمختلفين وقال: نلك علىما قضينا وهذذا

$$
\text { على ما نقضي (1) (1) }
$$

ثَذغير الأزمنة والأككة والأحول و الذيات و العو ائد. وقد أعاد ابن القيم رحمه الله

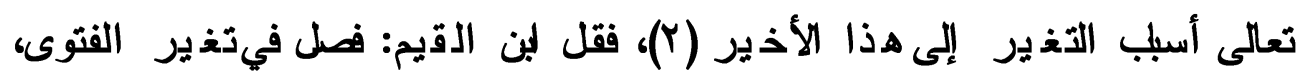
و اختلافها بمبتغ ير الأزمنة و الأككنة و الأحو ال و الذيات و العو ائد (r).

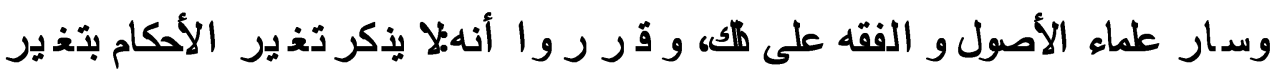
الزمان (ع)، إلا أني أرى أسبلب التغ ير أكذر من للككما ر أيت (0).

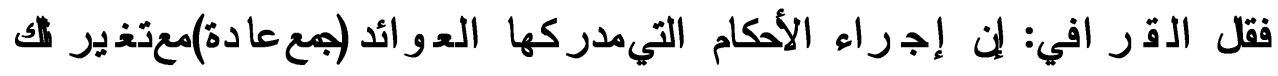
العو ائدهلف الإجماع وجهالة في الدين، بلكلما هو في الـ رديعة يثبع العو ائد، يذغ ير الدكم فيه عند تغ ير العادة إلى ماتثقضيه العادة المتجددة (7).

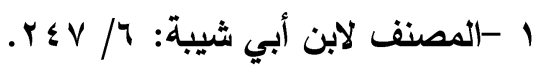

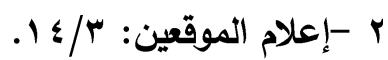

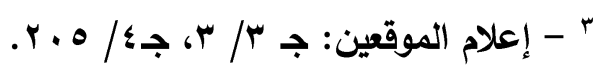

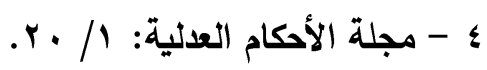

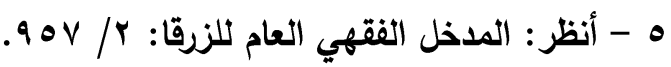

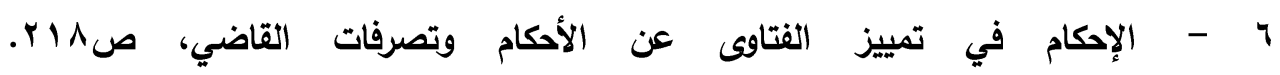




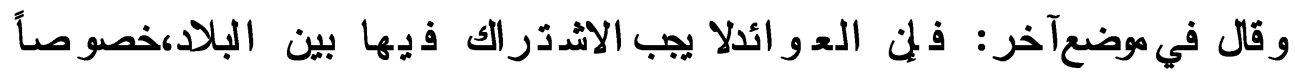

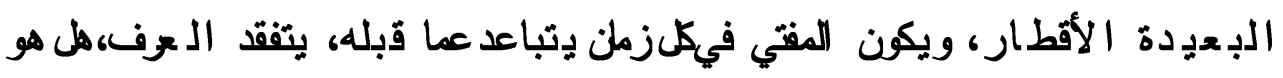

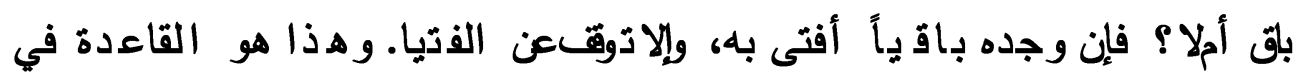

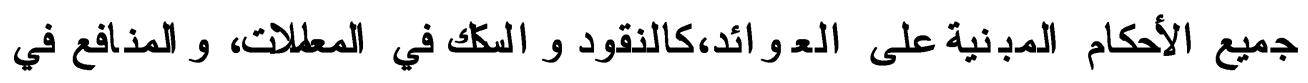

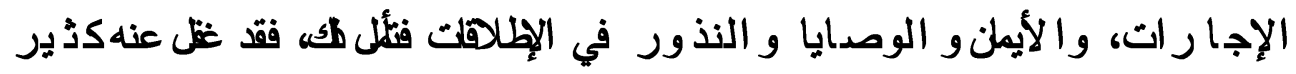

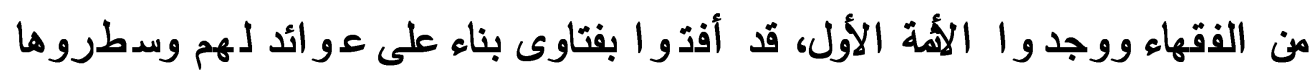

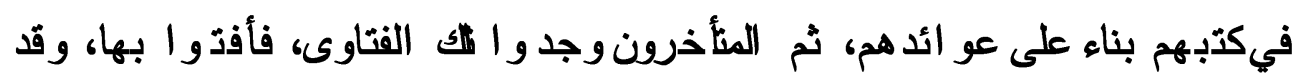

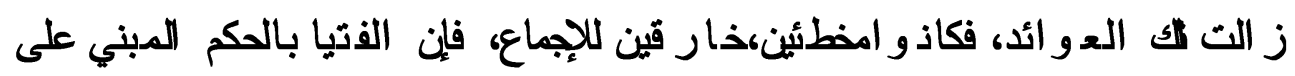

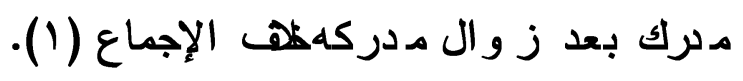

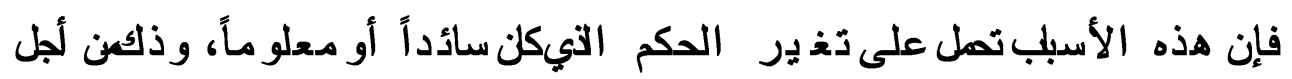

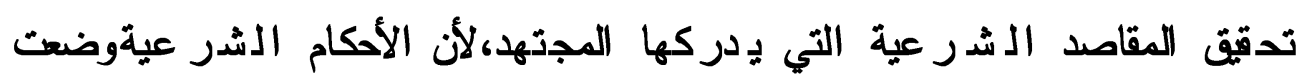

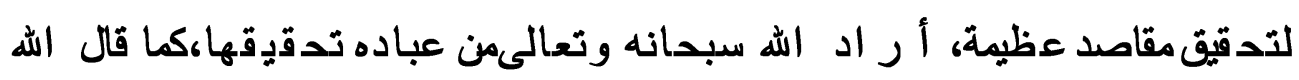

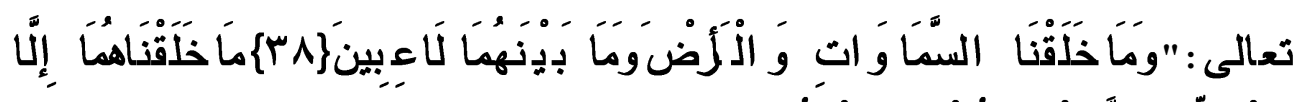

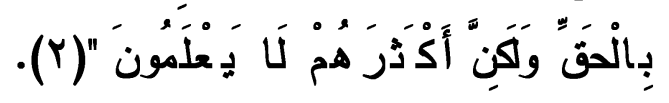

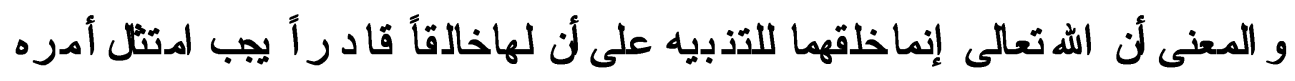

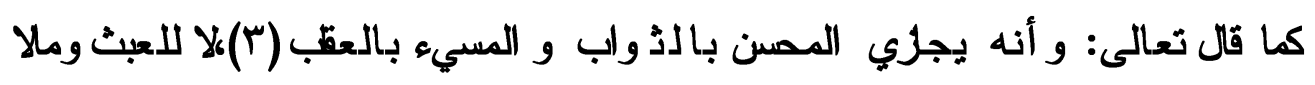

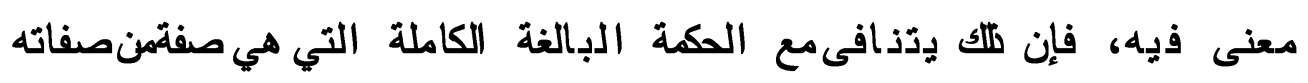
عز وجل.

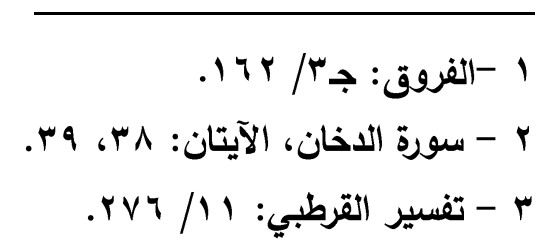




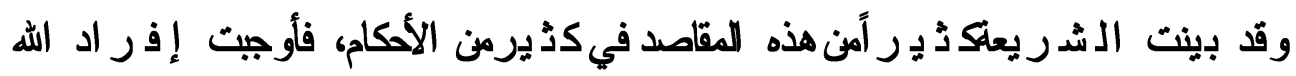

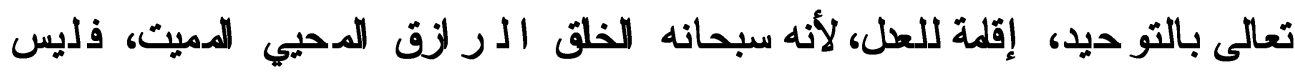

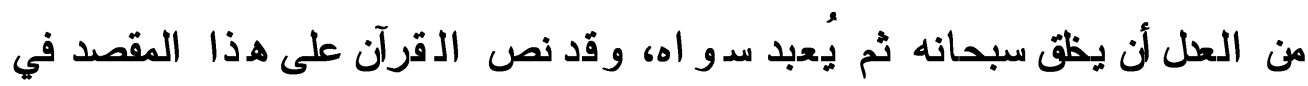

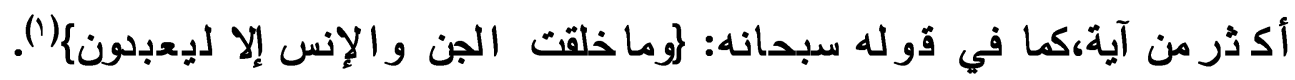

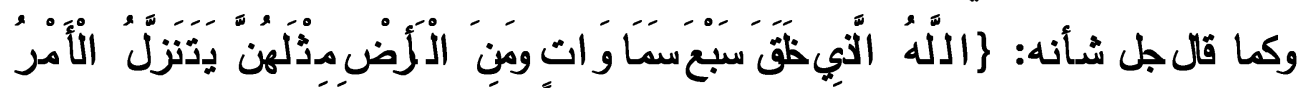

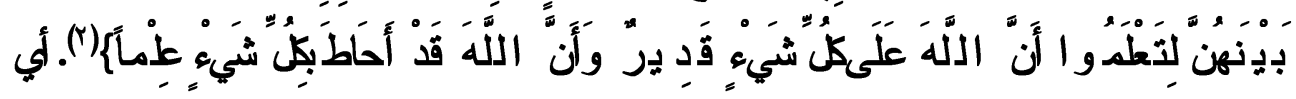

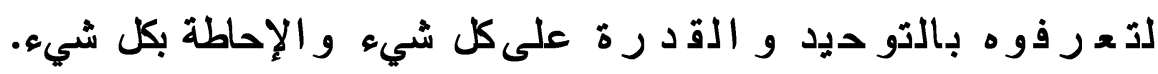

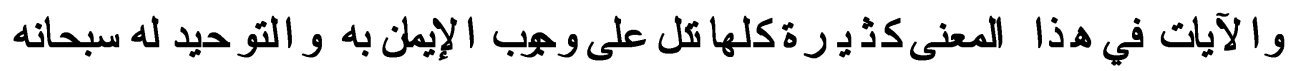

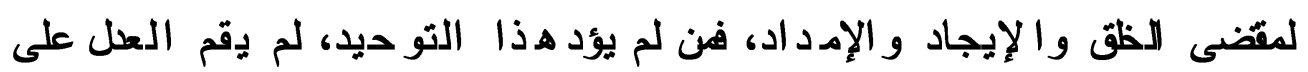

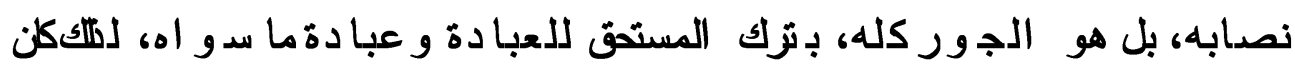

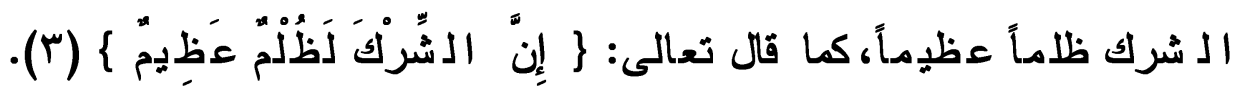

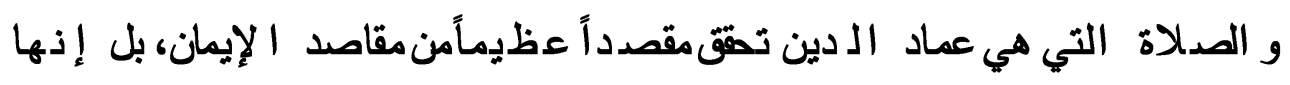

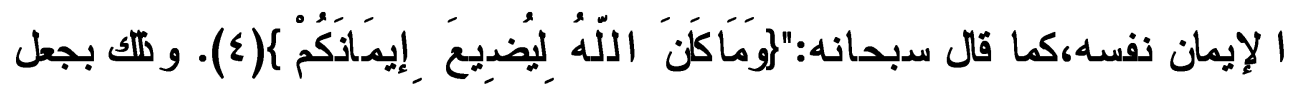

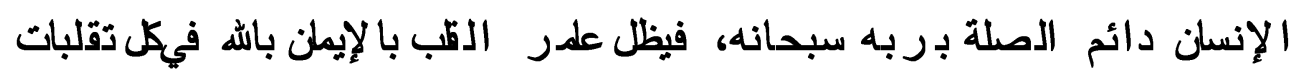

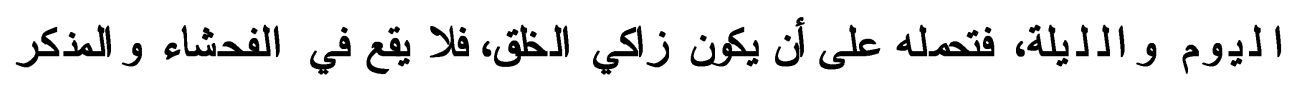

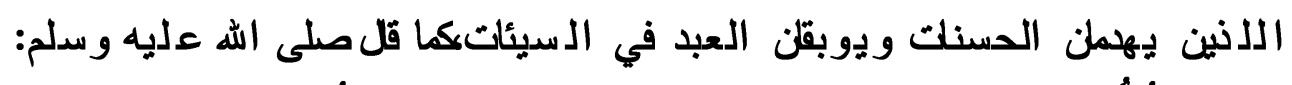

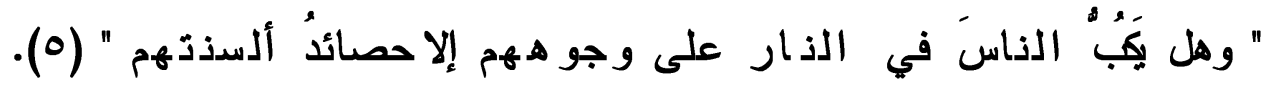

1 - سورة الذاريات، الآية:

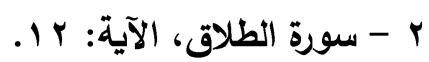

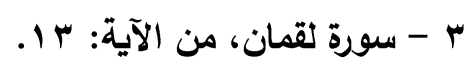

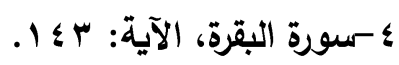

ه-أخرجه الترمذي في الإيمان، من حديث معاذ بن جبل رضي الله تعالى عنه. 
و الزكاةكطاكتمقمقصداً إيماذياً عظيماًكمنتطه ير النفسمن الشح و البخلكما

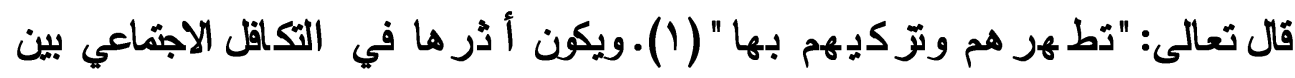

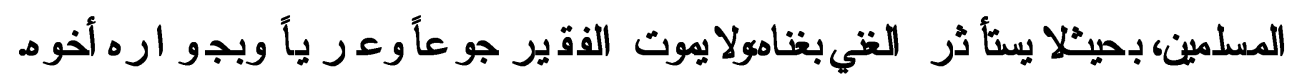

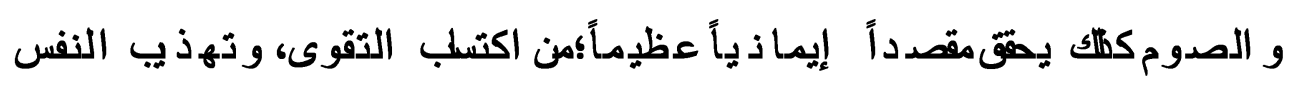

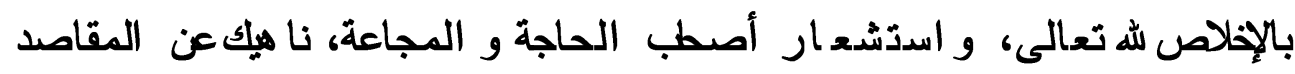

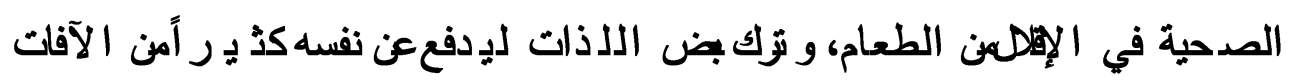

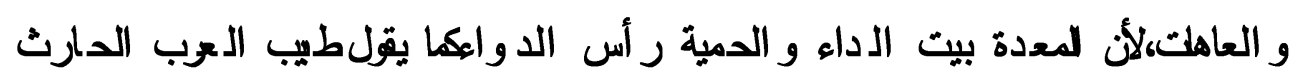
بن كلدة. و الحجكظك يحقمقاصد إيمانيةعظيمةكمن استشعار التو حيد لله تعالى، و قصده

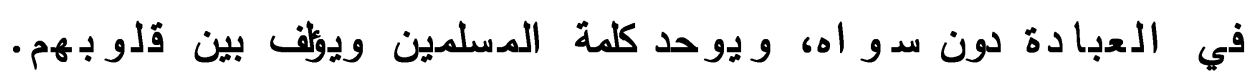

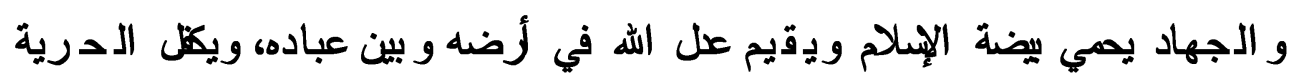
الد دي ذية.

و النكاح يحمي الأعر طنه ويحفظ النسل، ويجقى النوع الإنساني على وجه الكل.

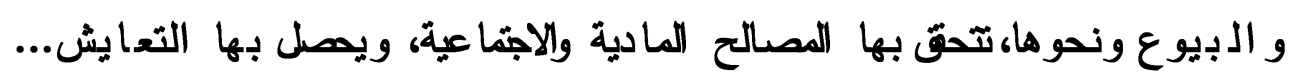

وهكذاكل الأبواب الفق هيةتمقىمقاصد شر عية، و اجتماعية، تتمق بها الحياة الإذسا نية على وجه الكمال وصلاح الحال و المآل.

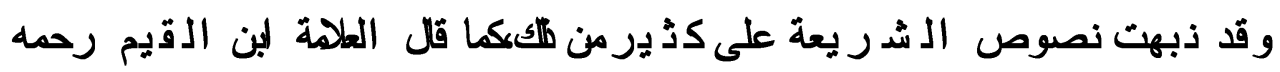

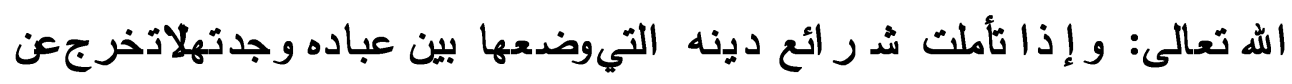

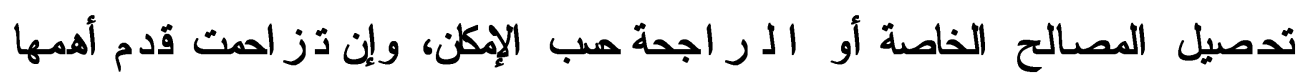
وأجلها، وإن فاتت أدناهما.

1 -التوبة، من الآية: ب.1. 
وتعطيل المفاسد الخاصة أو الـ ر اجحة بمب الإمكن، وإنِ دز احمت عطل أعظمها فساداً باحتمال أدناها. قال: و له ذاوضع لُكم الحكمين شد ر ائع ديذه د دالة الة شاهدة له بكمل علمه وحكته

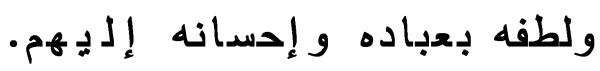

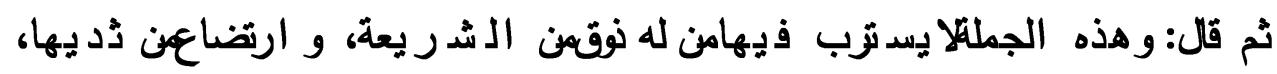

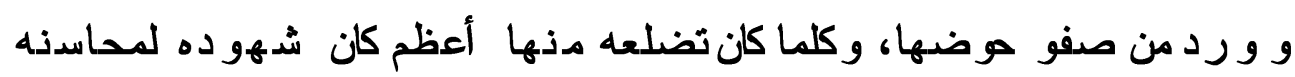
ومصدالحه أكل.... إلى أن قال: و القرآن وسنة رسول الله صلى الله عليه و سلممملو عانمن تعليل

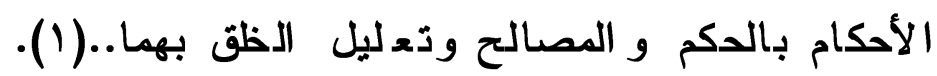

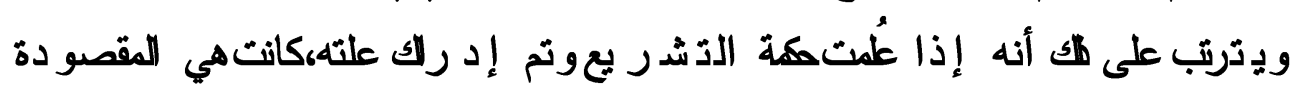

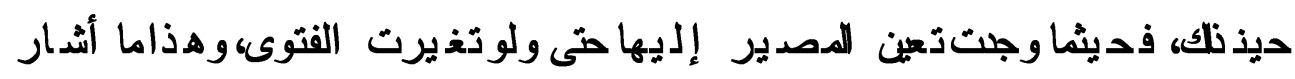

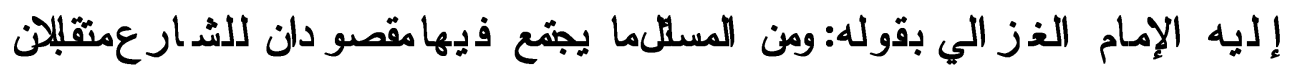

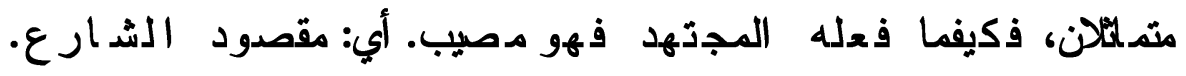

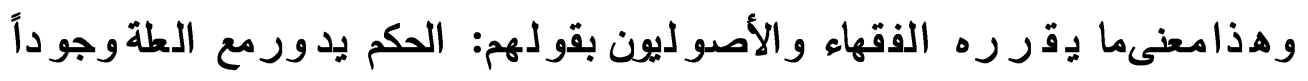
و عد ماً(Y).

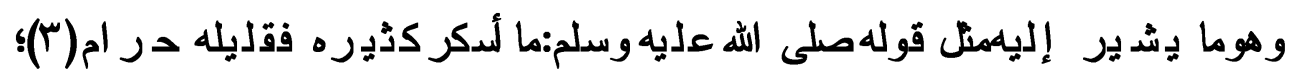
فقد جل العلةمناط الحكم، فحيثماوجت وجد الدعلول، وهو حرمة شرب قدلئلئل

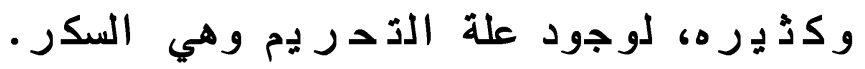

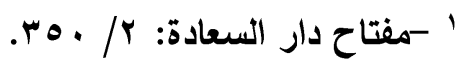

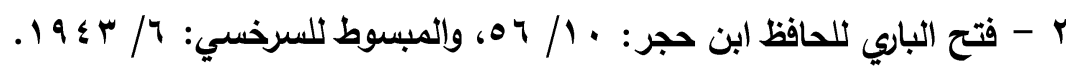
r - أخرجه أبو داود في الأثربة، والترمذي في الأشربة، من حديث جابر، وقال: حسن غريب. 
و يُش ير إليه قوله صلى الله عليه وسلم: وقد سلّعن شر اء التدر بالرطبه فقل

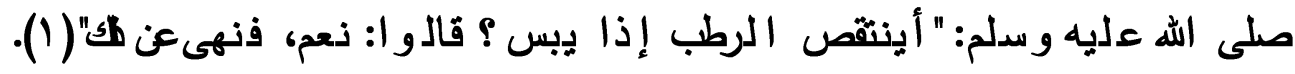

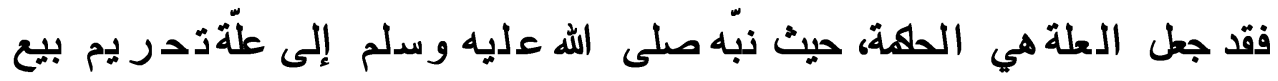
المثلى بجنسه، وهى التظنل التي يصل بين التمر و الرطب عند يبسه. ولمأكاتت

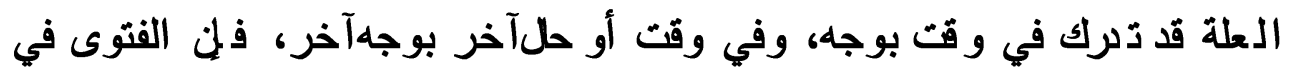

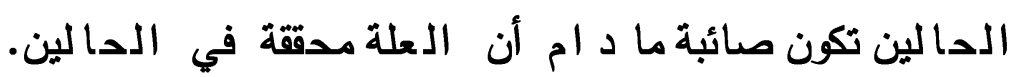

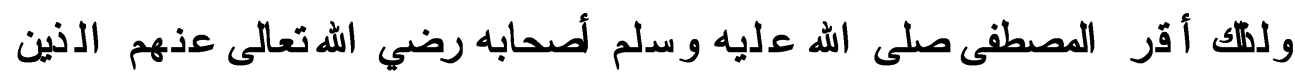

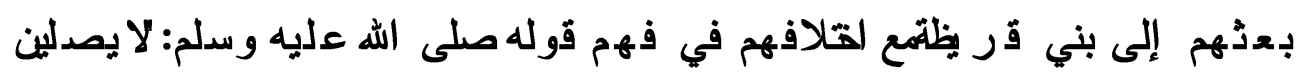

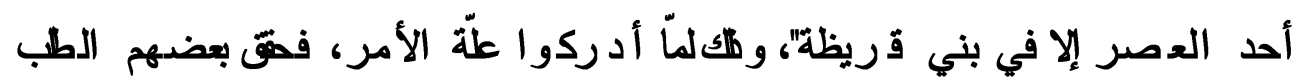

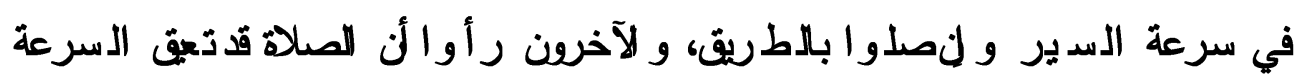

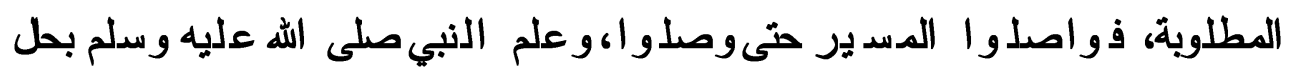

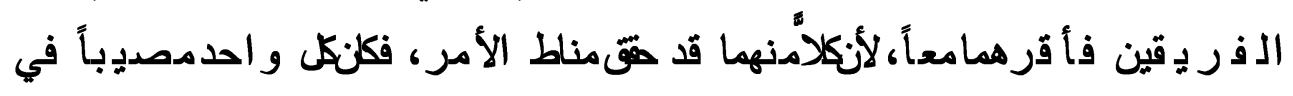
فعله مع اظثق العملين والاجتهادين. وهكذا في نظائر كذّير ذرة فيكل أبولب الفقه، يجل النبي صلى الله عليه وسلم العلّة

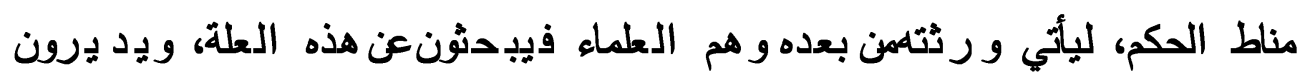

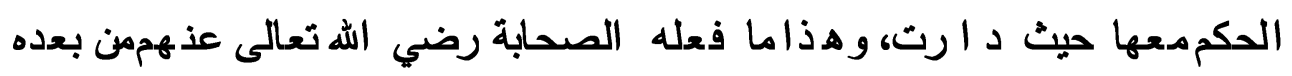

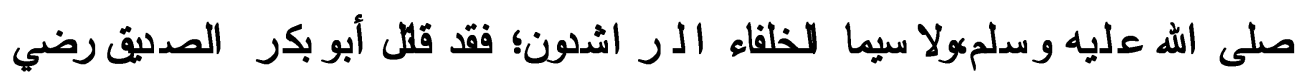

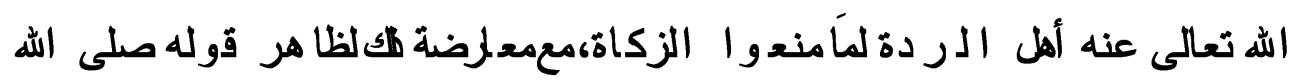
عليه وسلم: " فإذذا قالوها فقد عصدو امني دماءهم وأدو الههم إلا بحقها" (Y).

1 - أخرجه أبو داود في البيوع، والبييوع في البيوع، من حديث سعد.

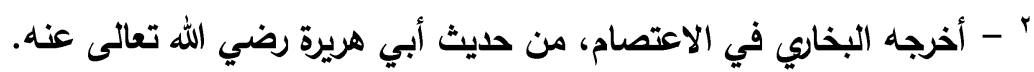




\section{البمش الأولول}

\section{السبب الأول: تغير الزمان \\ المطلب الأول: معنى تغير الزمان}

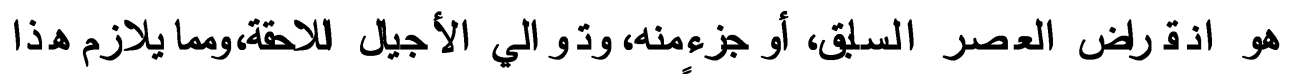

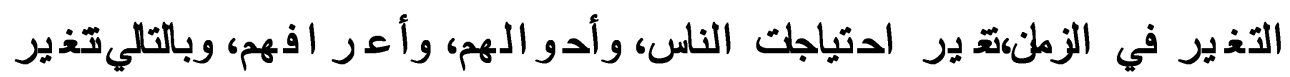

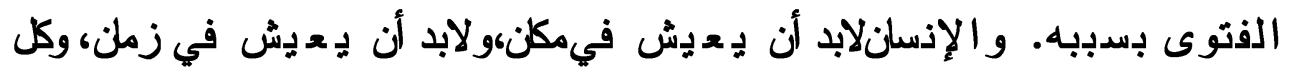

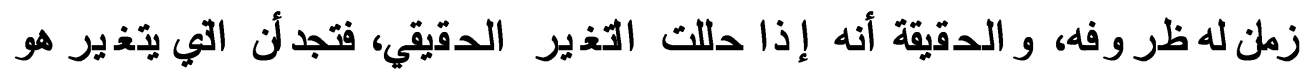

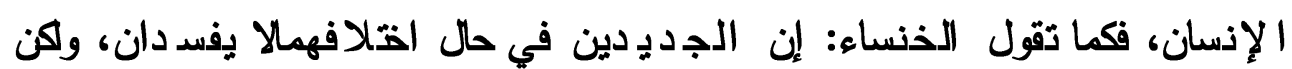

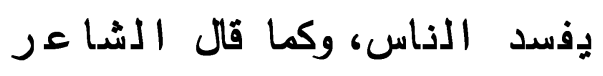

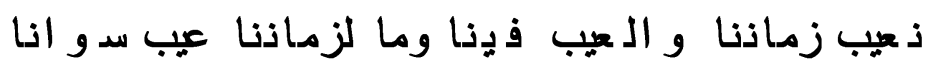

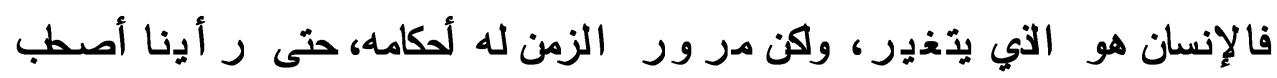

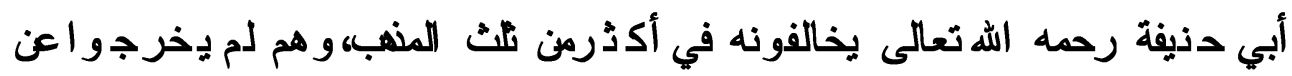

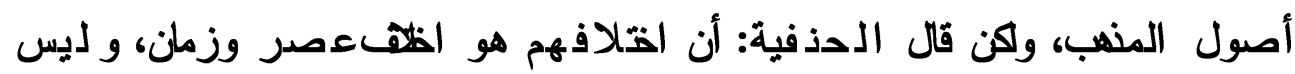

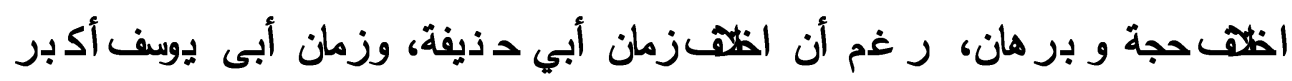

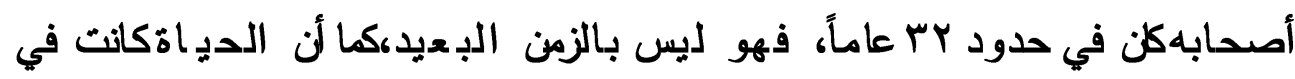

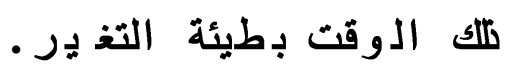

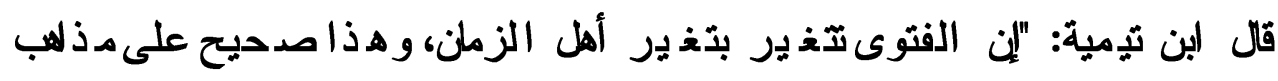

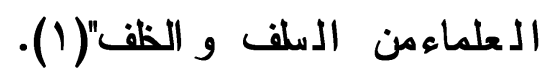

1- الفتاوى الفقهية الكبرى: T/ TV 


\section{المطلب الثاني}

\section{أمثلة على تغير الفتوى بتغير الزمان}

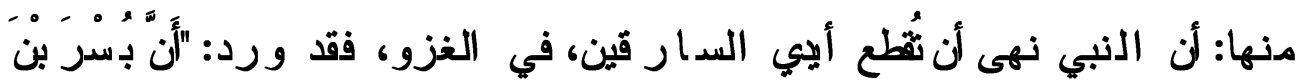

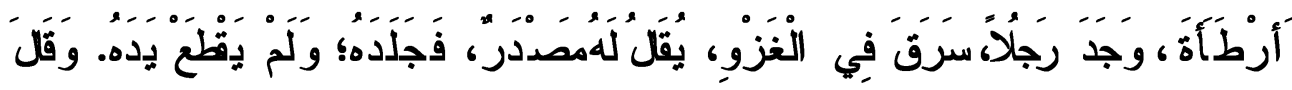

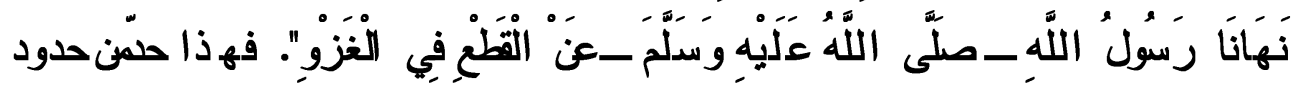

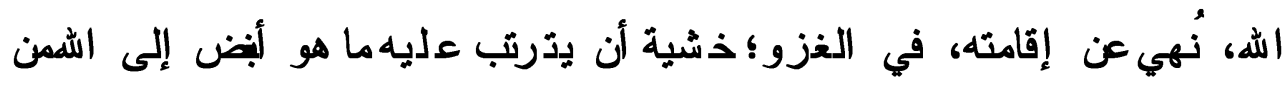

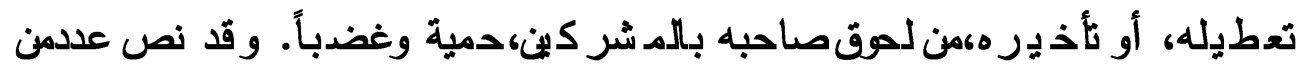

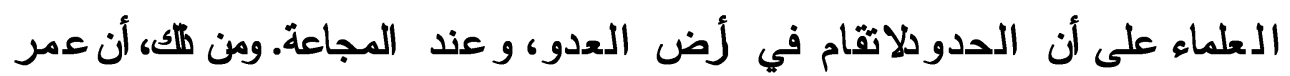

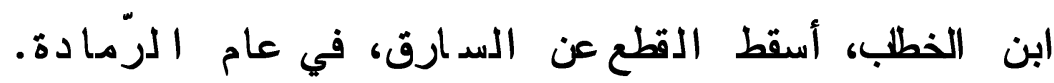

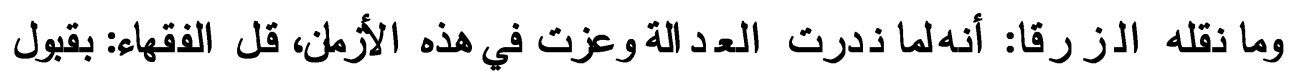

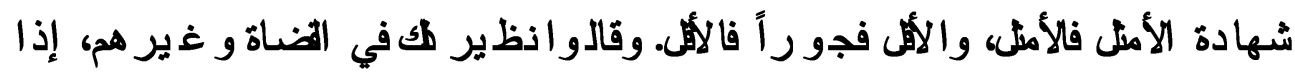

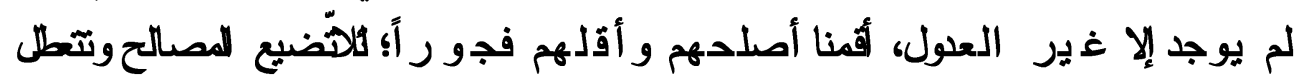

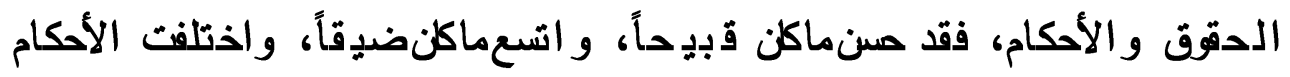

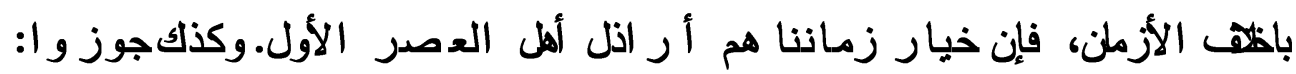

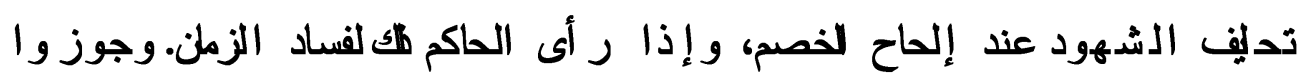

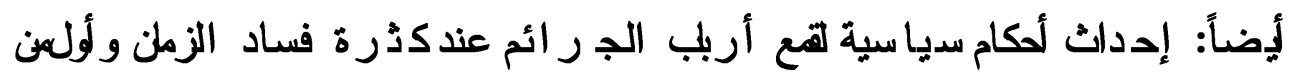

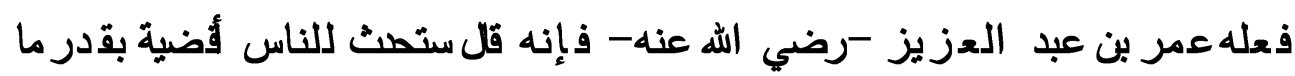

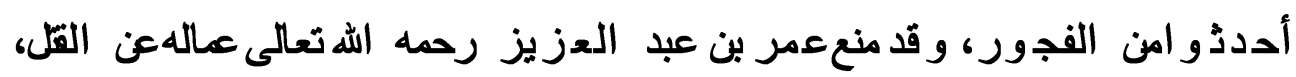

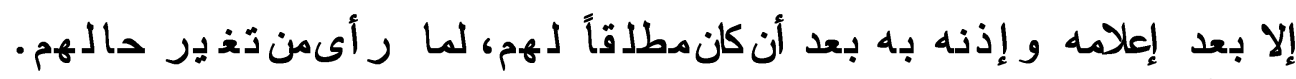

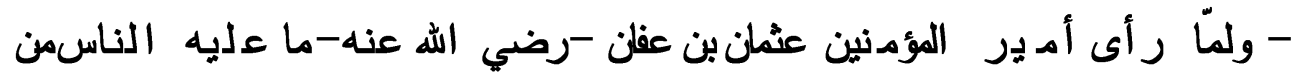

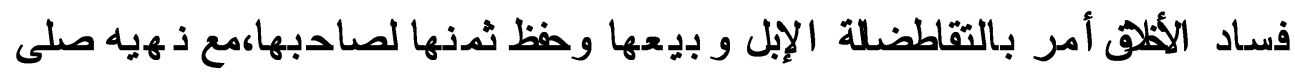


الله عليه و سدلم عن التقاطضلة الإبل( (1)، فعل ذكلما ر أكمن ذراب الذمم التي

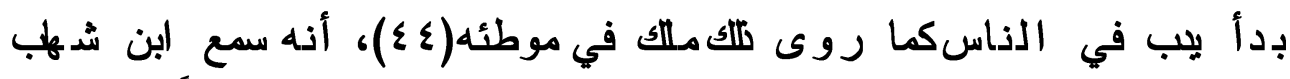

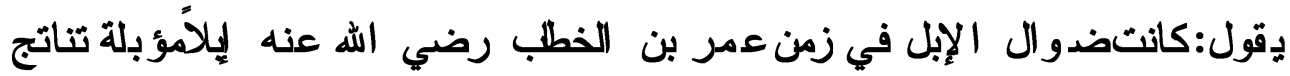

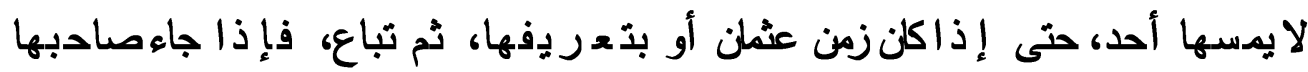

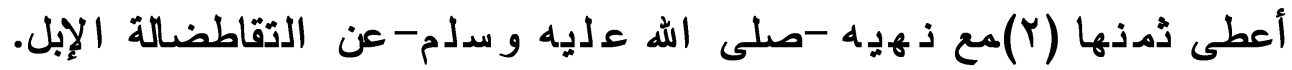

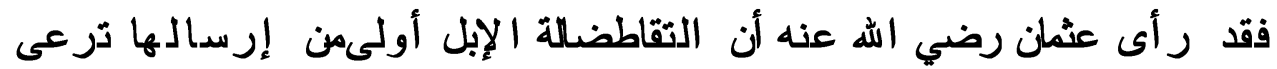

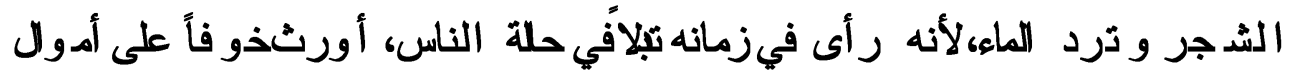

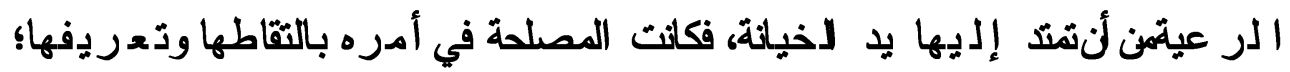

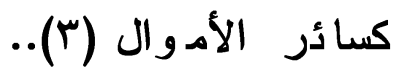
وكملك لما ر أىما عليه الناسمن خراب الذمم، في تطليق النساء فيمرض الموت

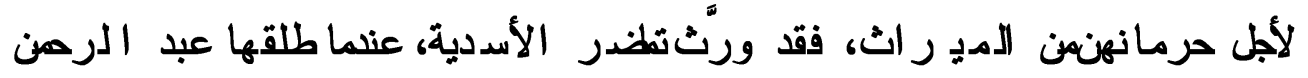
ابن عف رضي الله عذه في موض موته، معاملة له بذ قضض قصدده (ع). - ولما ر أى أم ير المؤمنين علي كرضي الله عنه-ما عليه حل الناس، و انفلاتهم،

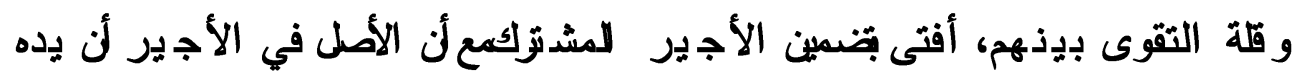

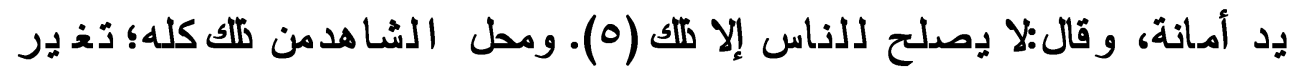

' - وهو ما أخرجه البخاري ومسلم من حديث زيد بن خالد الجهني، رضي الله تعالى عنه، وفيه:

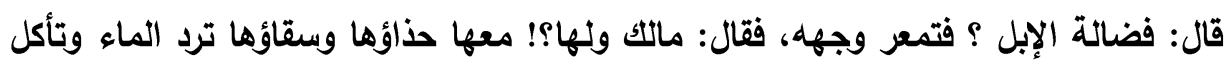

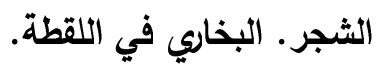
r - الموطأ، كتاب القضية، باب القضاء في الضوال.

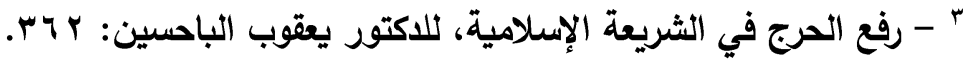

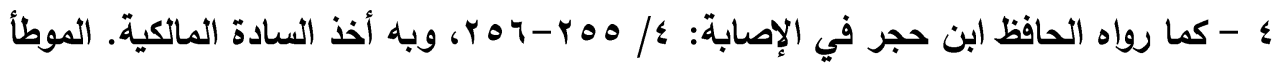

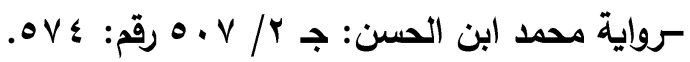

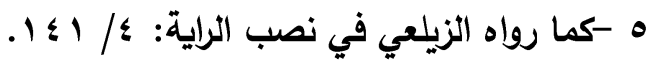


إفتاء هلاء الخلفاء الأربعة رضي الله تعالى عذهم أو أحكامهمن حال لآخر، تبعاً

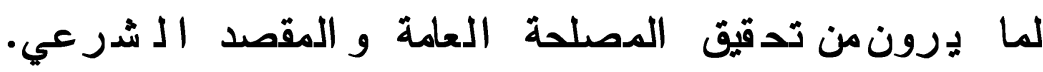

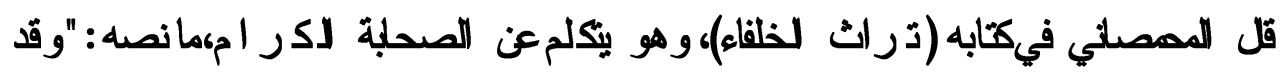

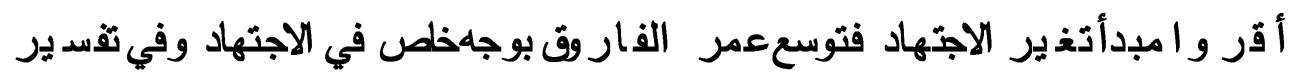

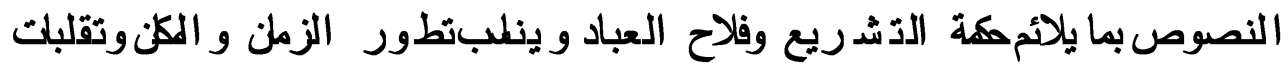

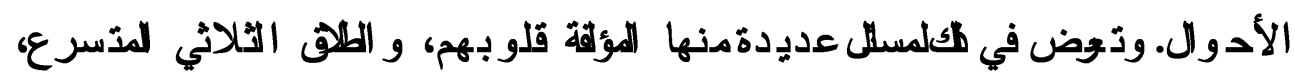

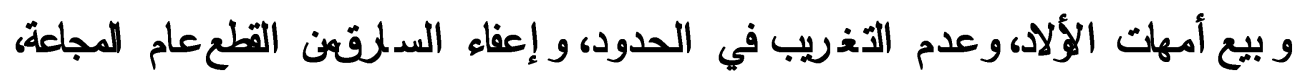

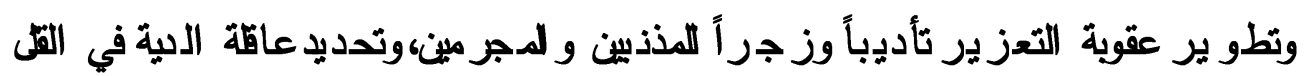

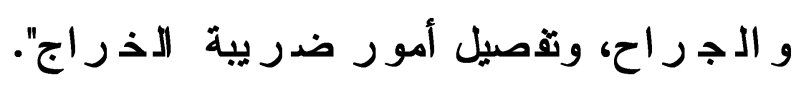

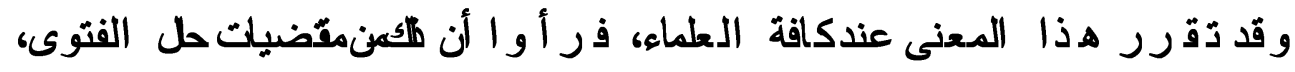

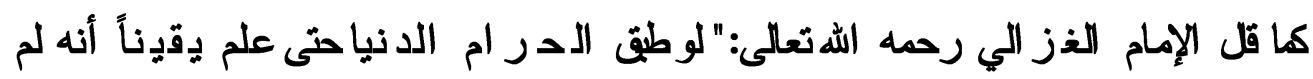

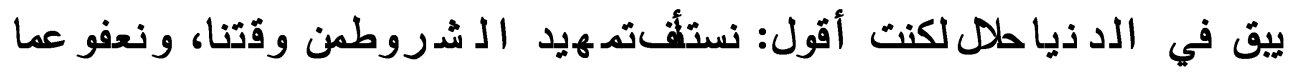
سلف، وذقول:ما جاوز حده انعكس إلىضده، فمهما حرم الكل إحل الكل (1).

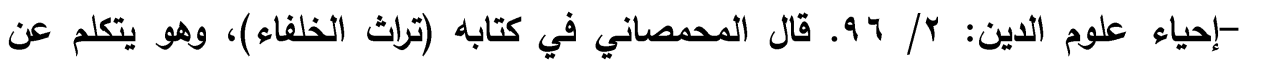

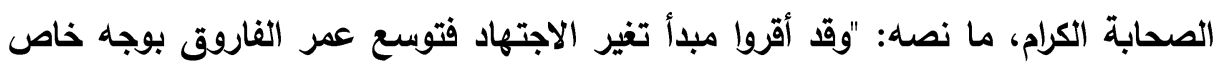

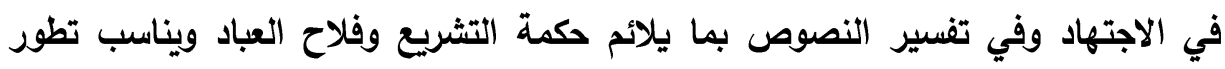

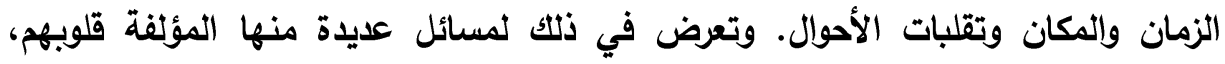

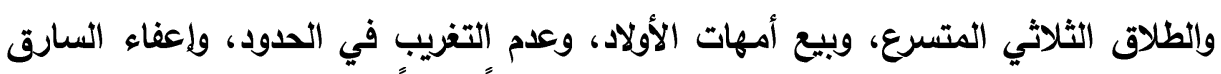

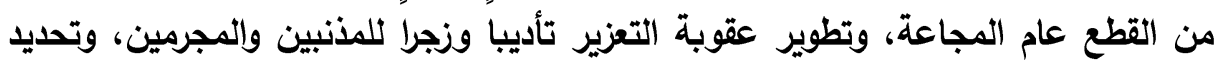

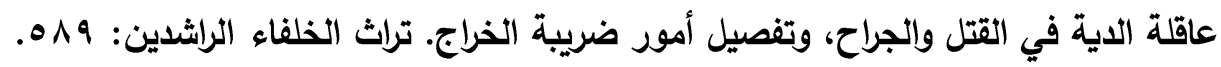


وهذاما أشدار إليه عز اللينبن عبد النلام رحمه اللهتعالى بقوله في قو اعده عند

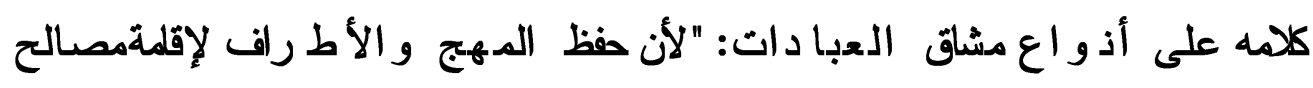

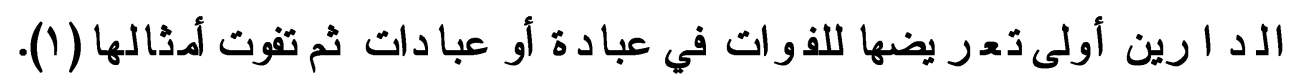

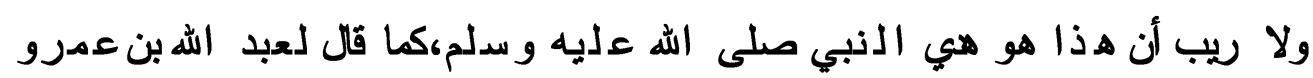

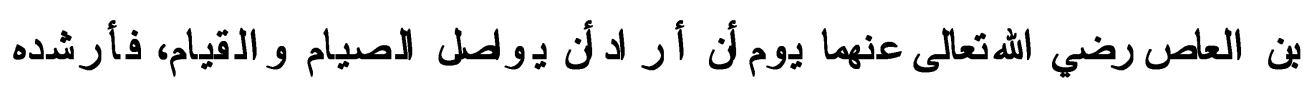

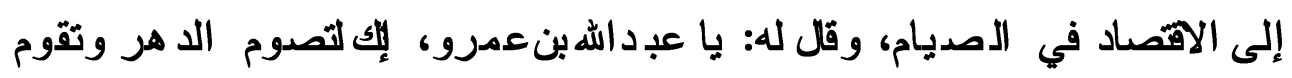

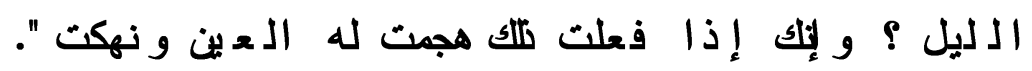
وفي ر و اية: " وذفهت له الذفس،لاصام من صدام الأبد ".

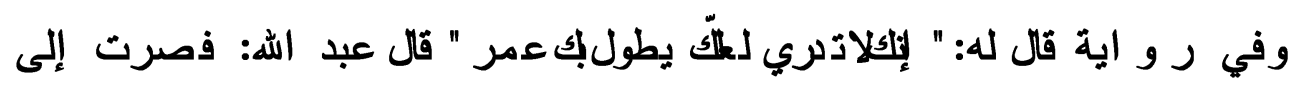

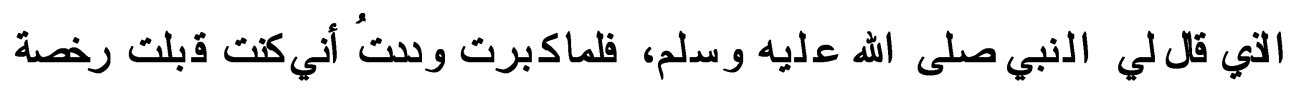
نبي الله صلى الله عليه و سدلم (Y). ف أرشده صلى الله عليه وسلم إلى مقصد الشارع في الحفاظ على حياته لتسذمر

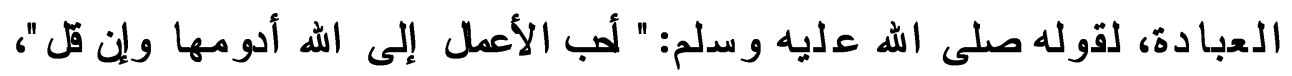

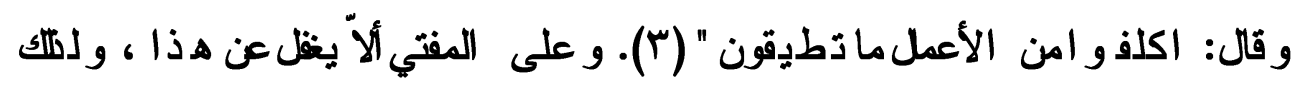

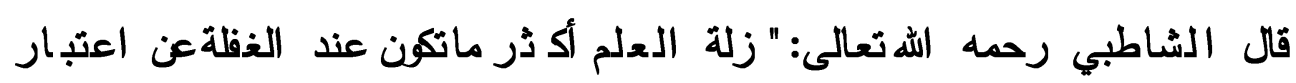

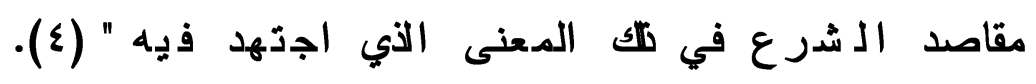

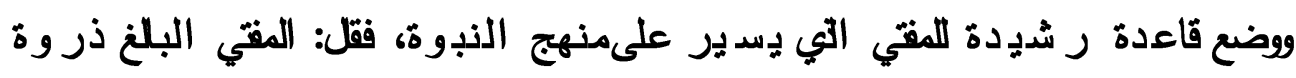

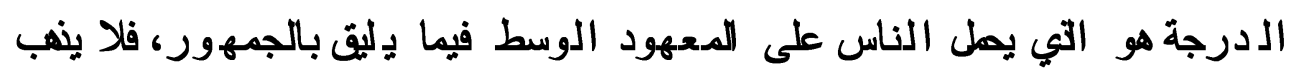

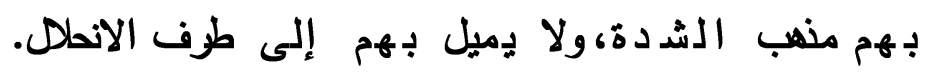

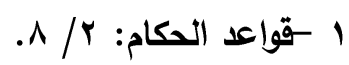

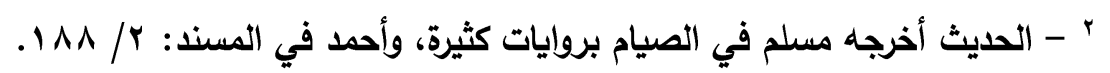

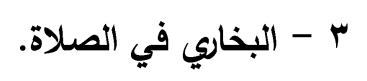

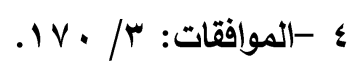




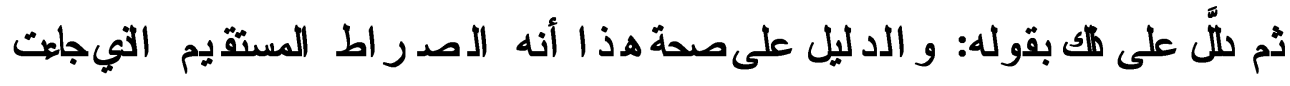

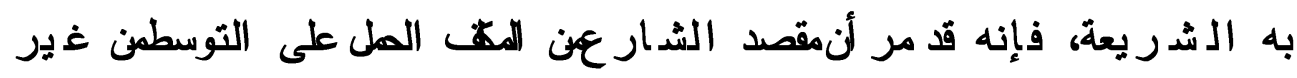

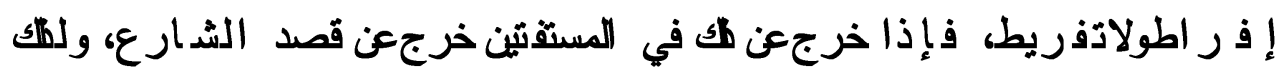

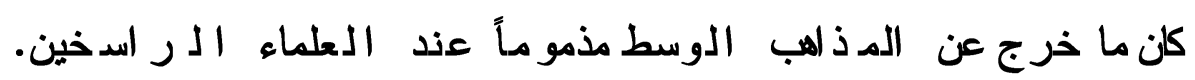

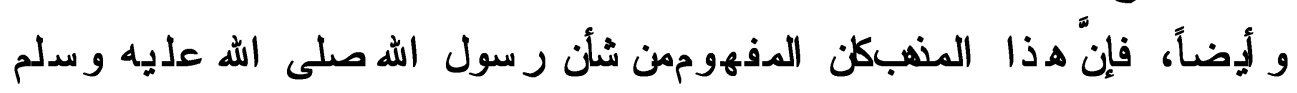

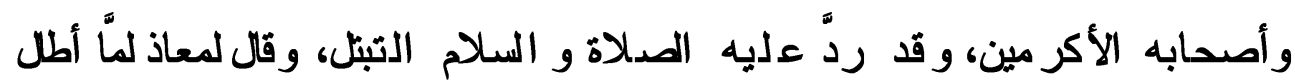

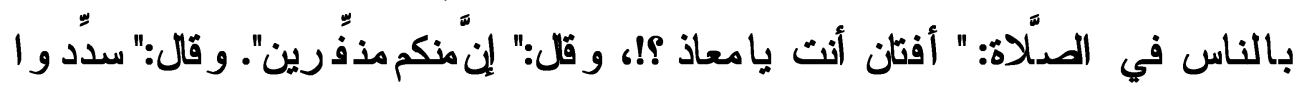

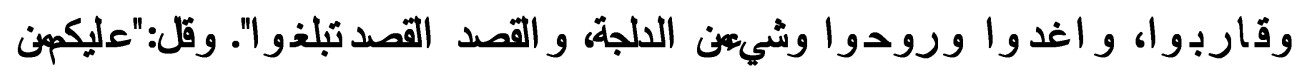

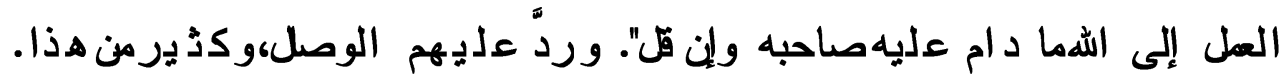

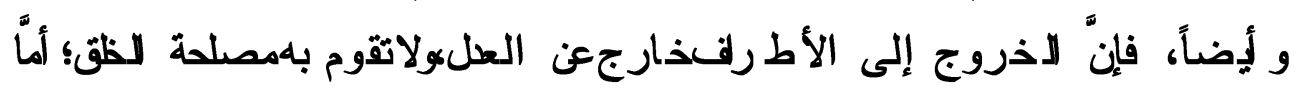

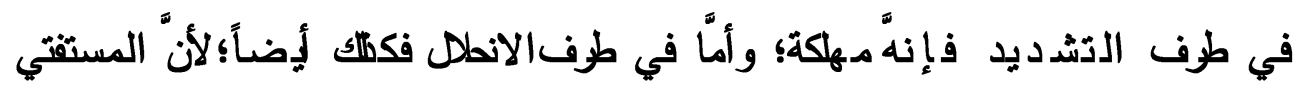

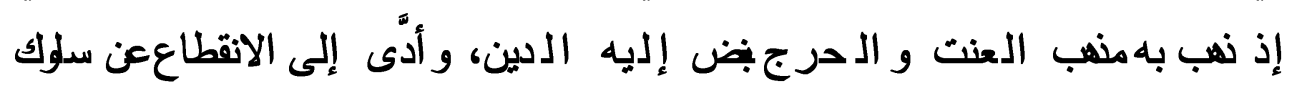

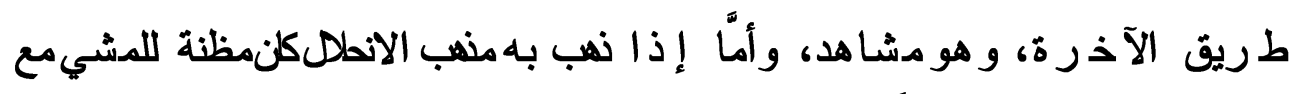

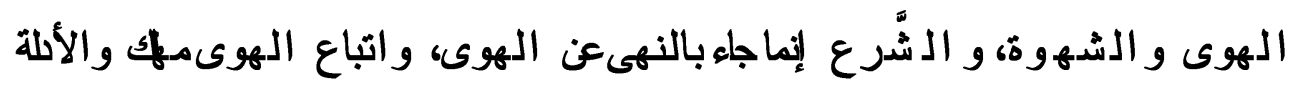

$$
\text { كثد بـرة (1) }
$$

وما يحث مثل لك إلا بسب الجمود على المذوّلات وعدم إد رلك المقاصد الشدر عية،

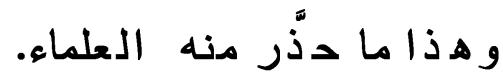
فقد قال الق ر افي رحمه الله تعالى: "و الجمود على المذوّلات أبدلَّلاه في الدين، و جهل بمقاصد علماء المسلمين و السلف الماضين"(Y).

$$
\begin{aligned}
& \text { ו- الموافقات: ؛ \& }
\end{aligned}
$$

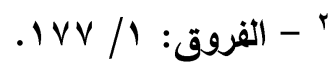




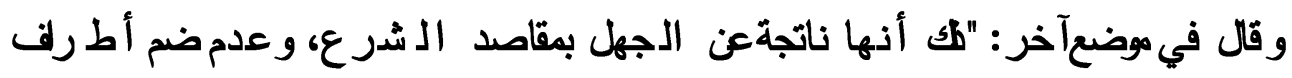

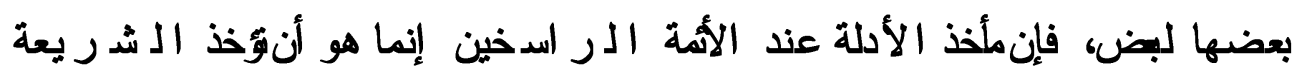

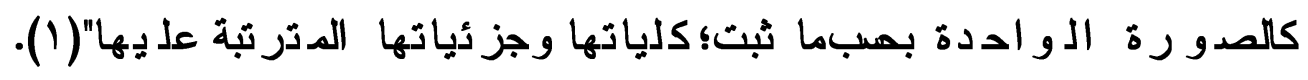

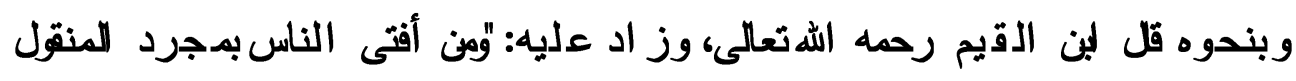

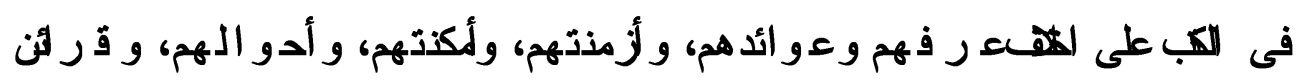

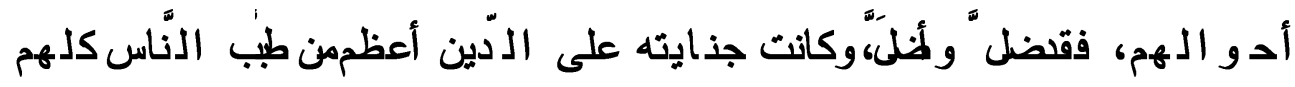

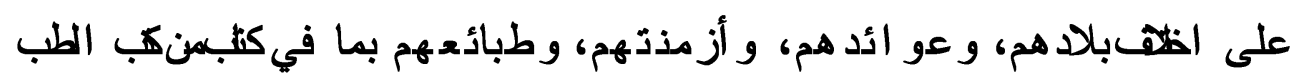

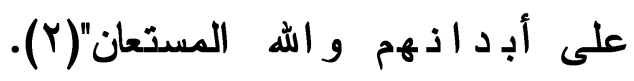

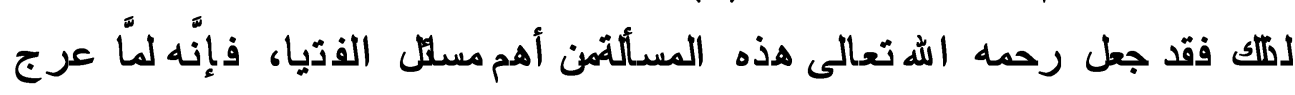

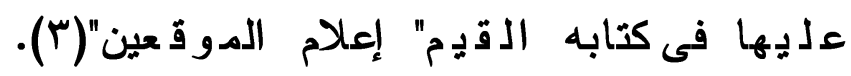

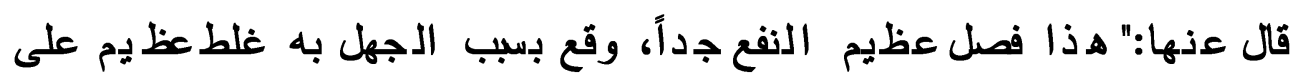

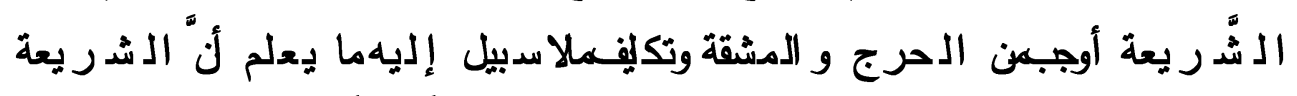

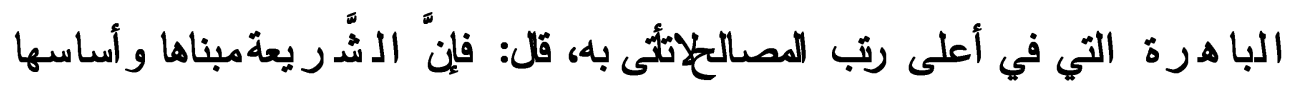

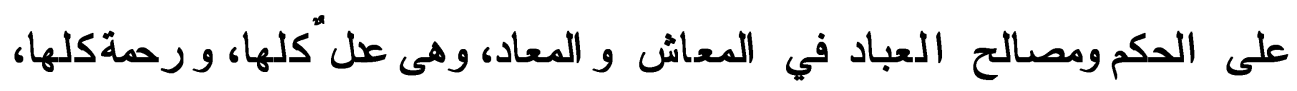

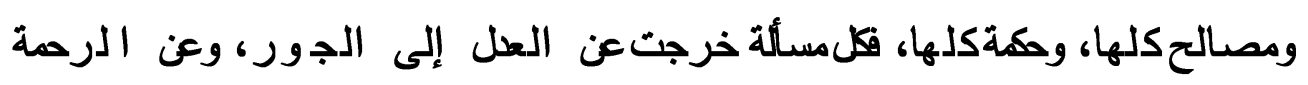

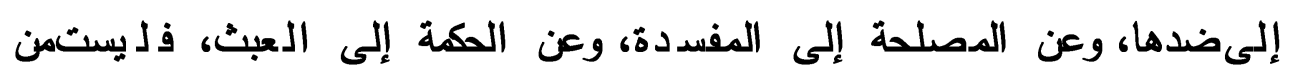

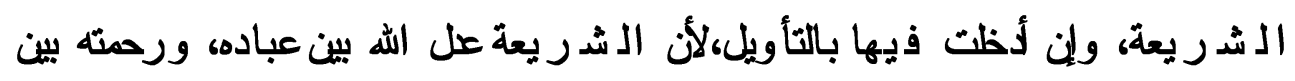

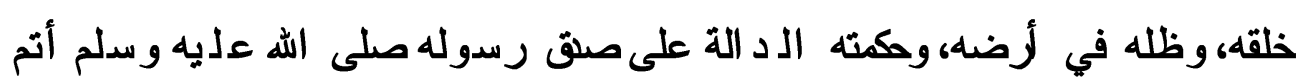

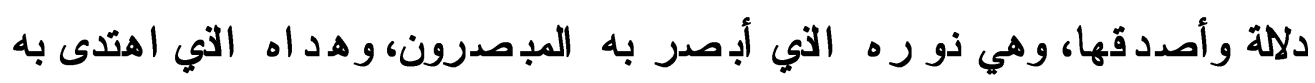

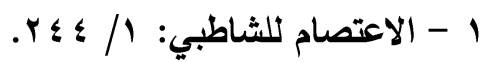

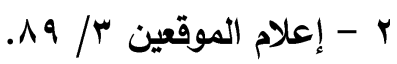
r - المرجع نفسه: r/ 
المهتلون، وشفاؤه التام التي به دواعكل عليل، وطر يقه المستقيم، التيهن استقام عليه فقد استقام على سدواء السدبل....

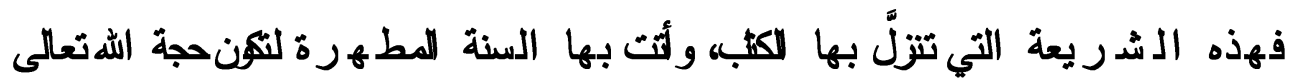

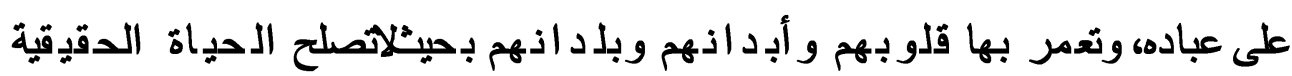

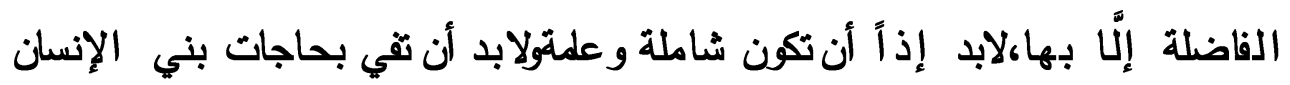

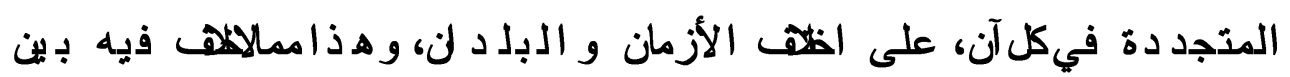

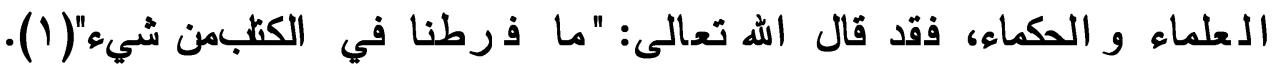

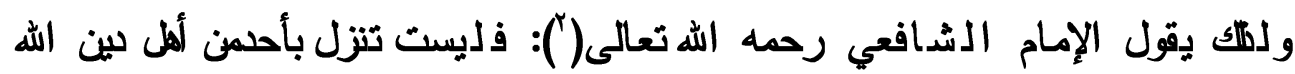

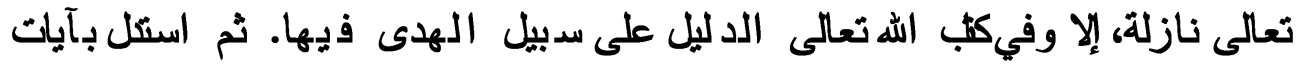

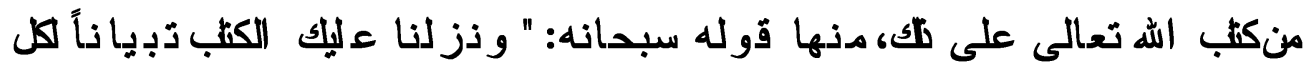

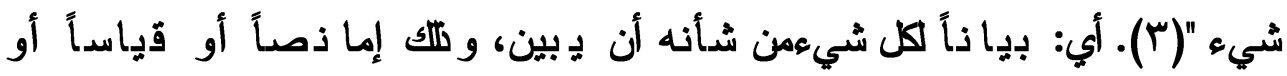

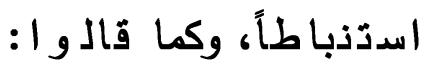

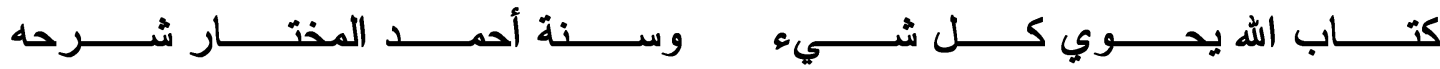
و قال إمام الـر مين رحمه الله تعالى:" المعتقد أنلا ئفض وقوع و اقعةمع بقاء

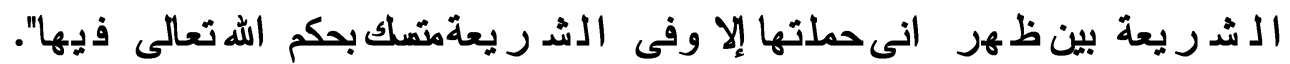

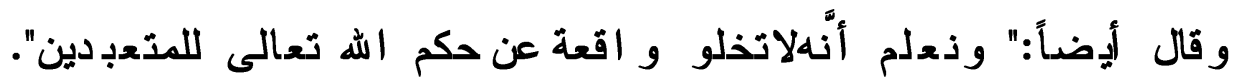

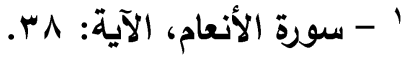

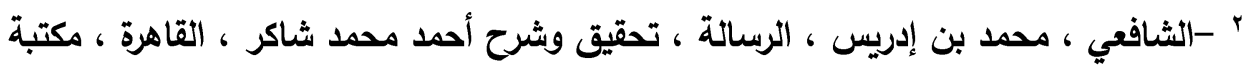

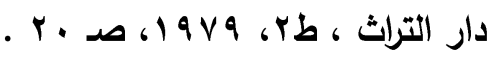

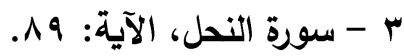




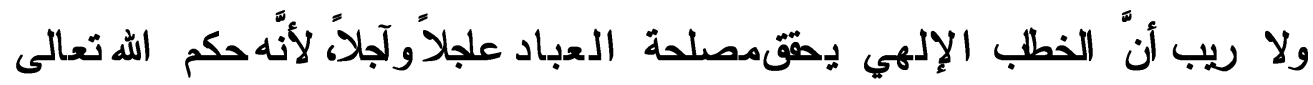

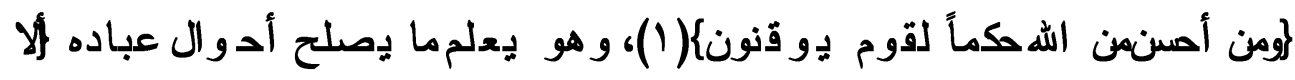

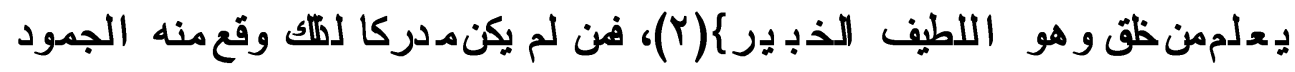

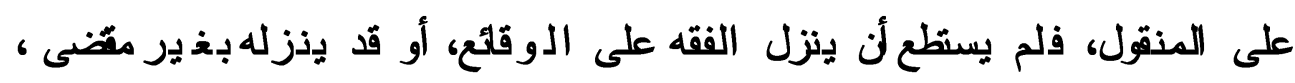

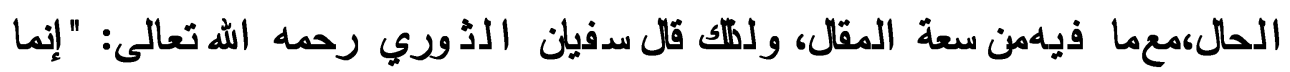

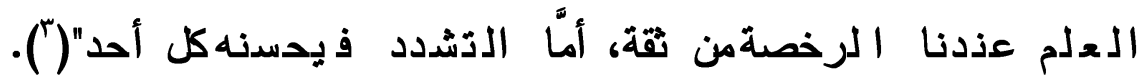

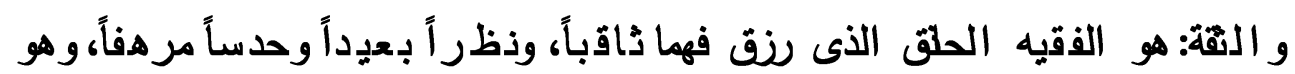

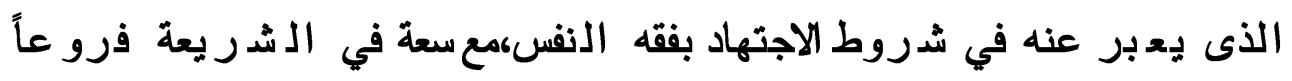

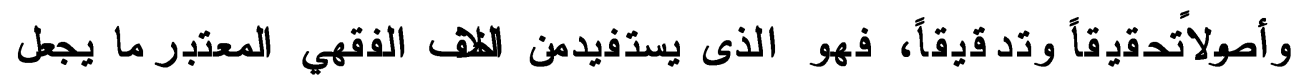

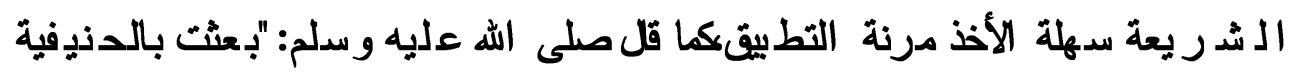

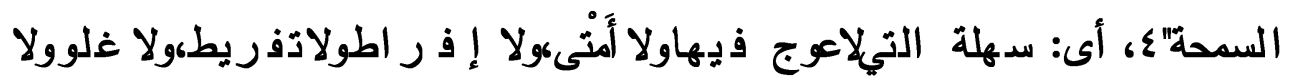

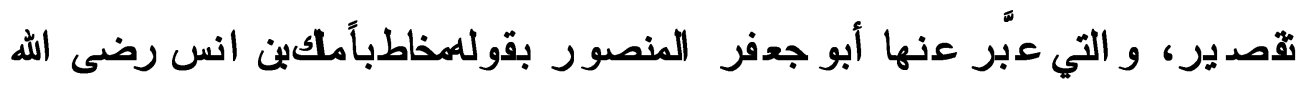

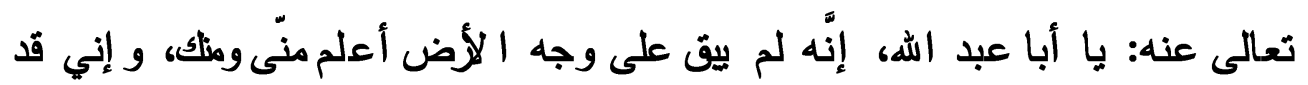

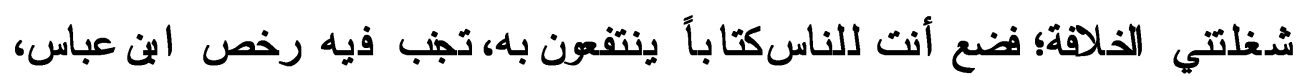

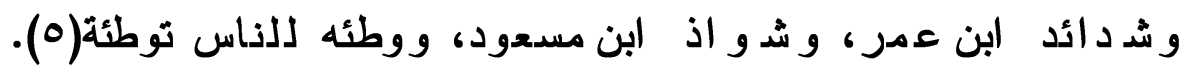

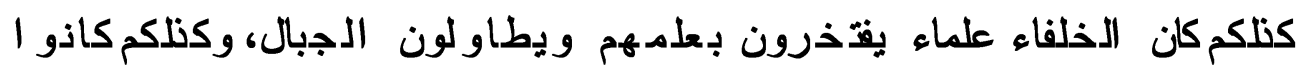

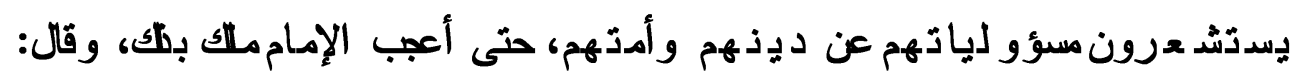

$$
\text { r - سورة المائدة، الآية: . ـ ـ }
$$

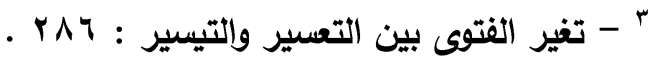

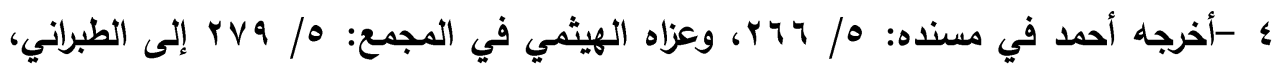
قال: وفيه على بن يزيد وهو ضعيف.

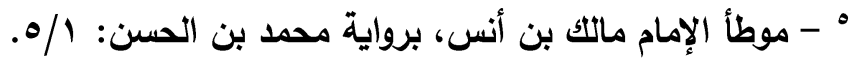


لقد علمني التصديف بومئذ. وبالفعل فقدخطظة منه جية أذرت على تألديفه، بل

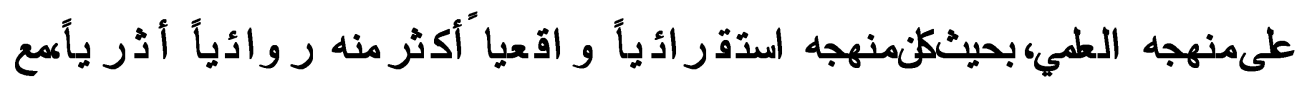

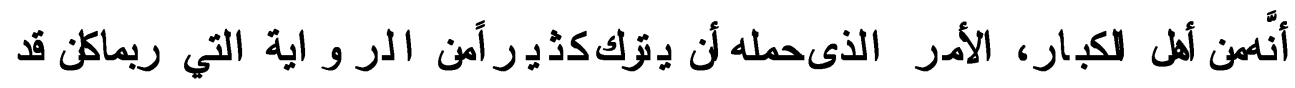

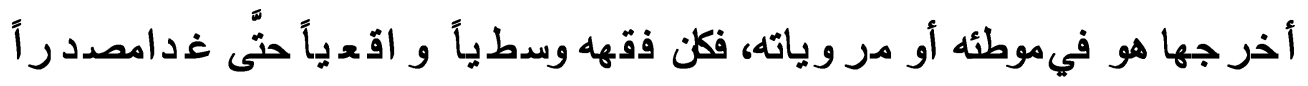

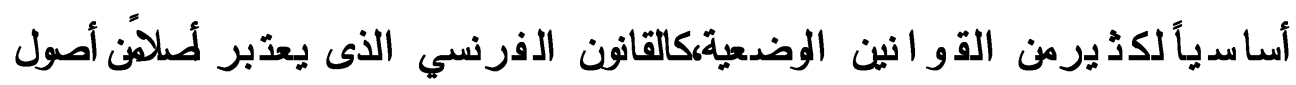

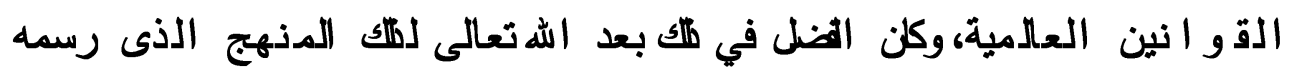

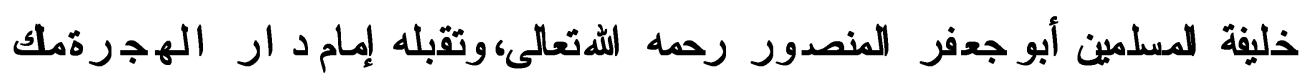

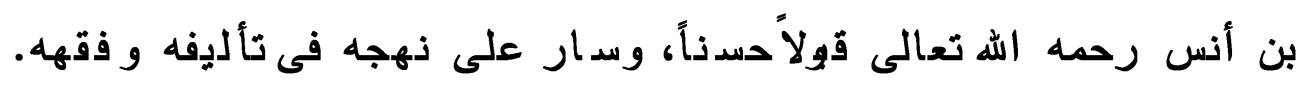

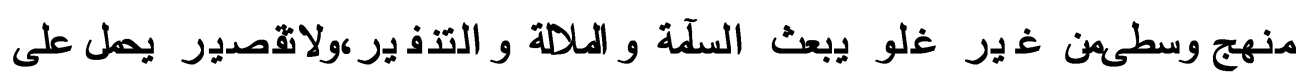

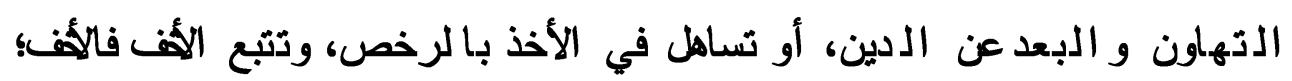
لأنه قد يؤدى إلى تزك الددين وتجنب العز ائم على الأقل.

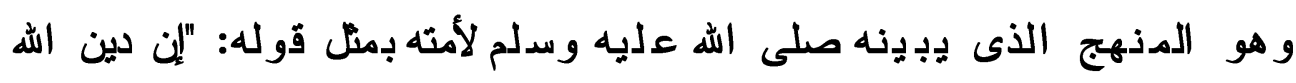

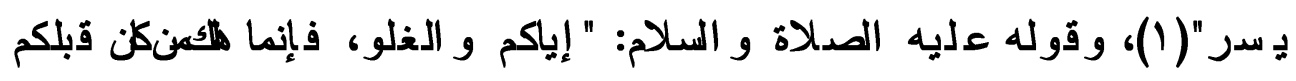

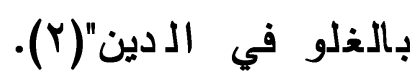

و قوله صلى الله عليه و سدلم: " هلك المتنطعون " قالها ديلاثا (با).

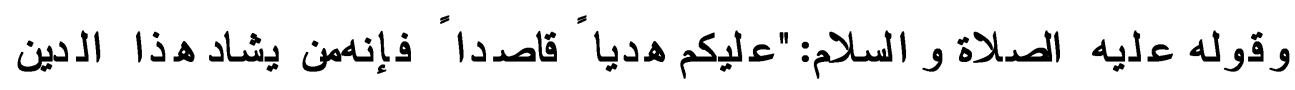

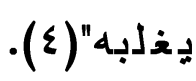

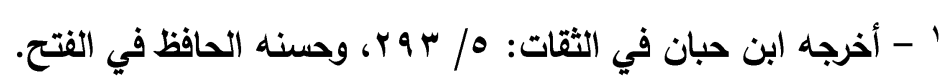

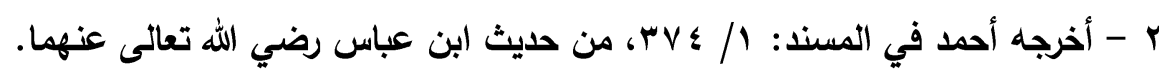

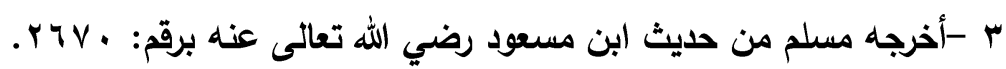

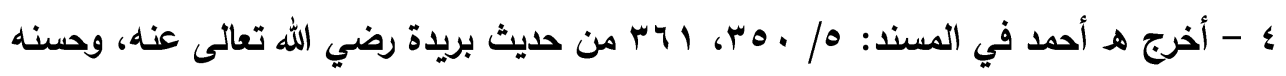

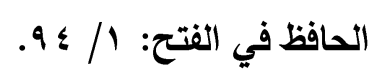


فه ذا هو منهج الإسلام العام الذى ارتضاه لعبادهكما قال اللهتعالى:"وكهاك

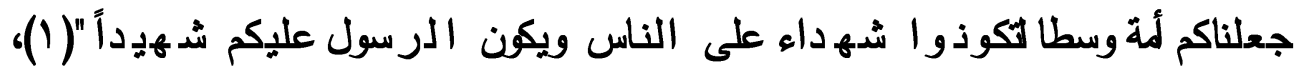

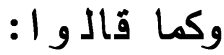

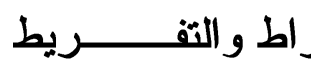

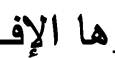
وشـ

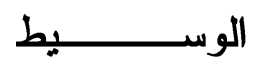
الأمـ

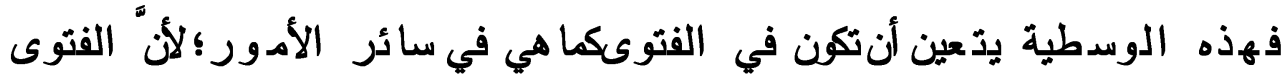

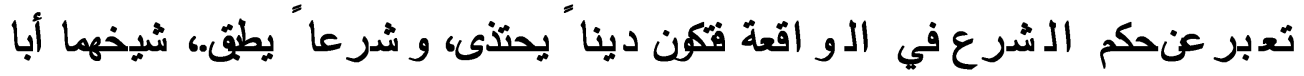
حذيفة التي نب إلى عدم اشدّر اط التركية في الحدود و القصاص بناء علىماكن فئن

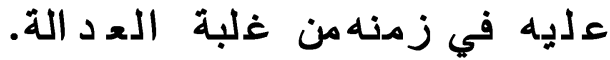

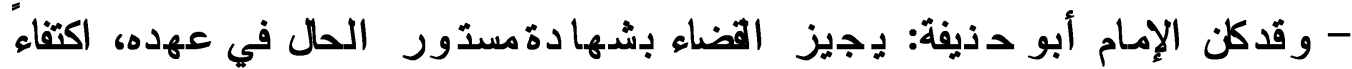

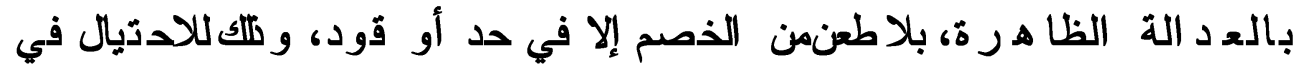

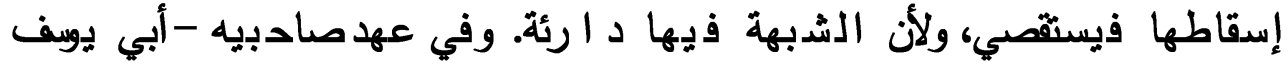

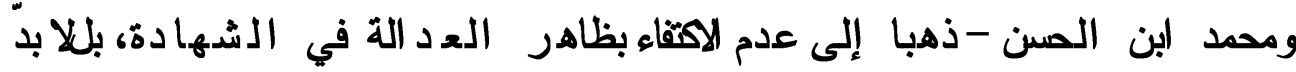
من التزكية؛ أي:صدارت الفتوى على تزكية الشهود سدراً و علناً، فيكل شيء (ل).

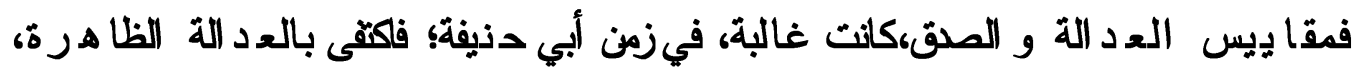
فيما عدا الحدود و القصاص. فلما فسد الناس، في زمنصاحبِيْه، لم يكتفيا بملك، و شرطا التركية؛ تلاتضيعحقق الناس. بشهادات الز ور التيتؤهي إلىضياع

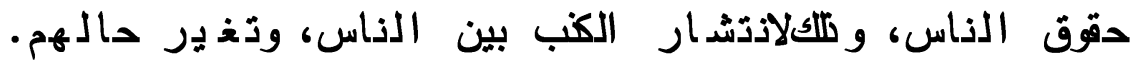

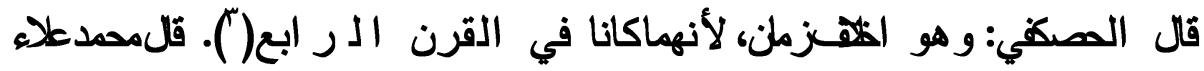

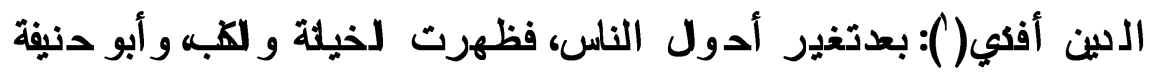

I - سورة البقرة، الآية:r 1

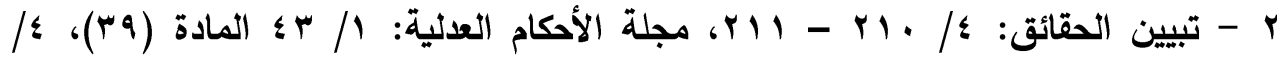
.491

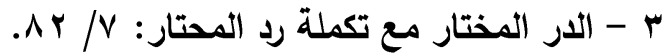


كلن في القرن الثلث -زمن التابعين كموهم ناس شهد لهم النبي كلى الله

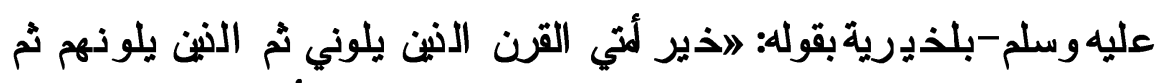

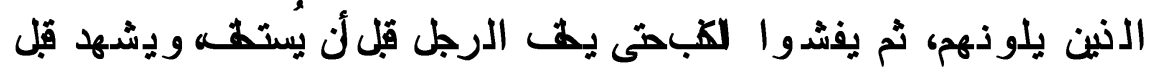

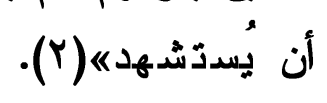

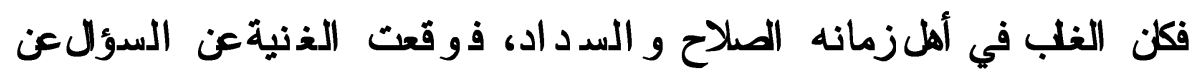

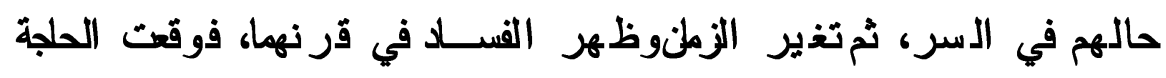

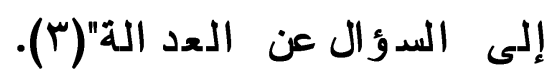

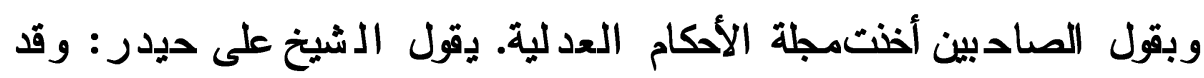

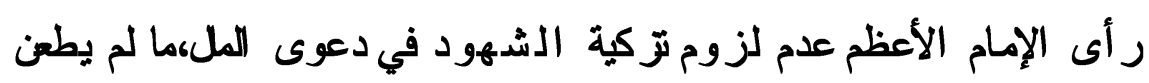

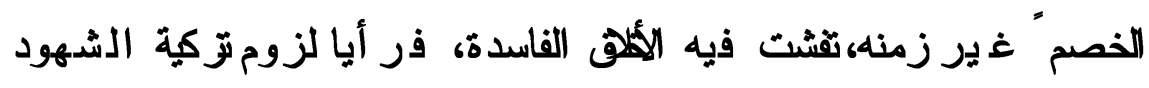

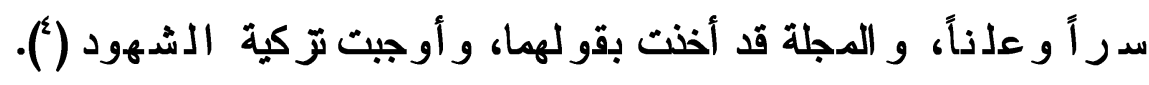

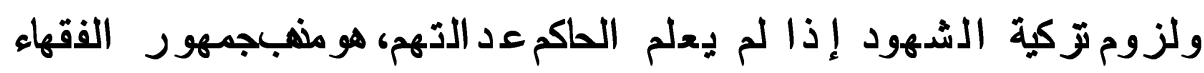

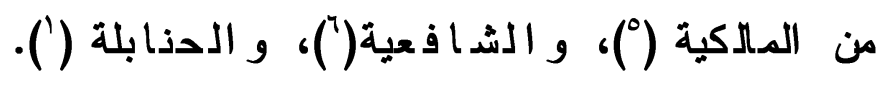

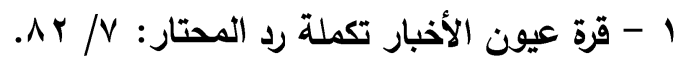

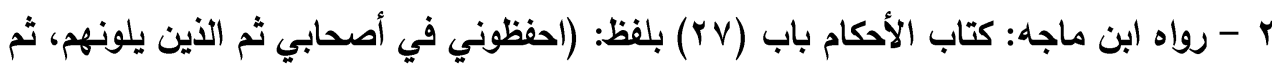

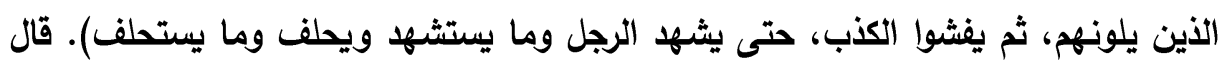

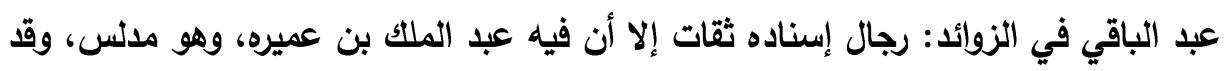
رواه بالعنعنة. وأخرجه البخاري بلفظ: (خير الناس قرني، ثم الذين يلونهم، ثم الذين يلونهم،

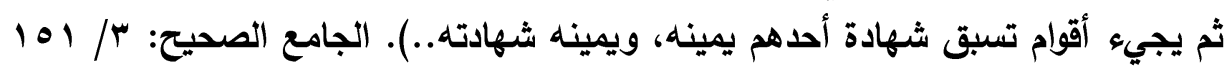

$$
\begin{aligned}
& \text { كتاب الشهادات، باب (9). }
\end{aligned}
$$

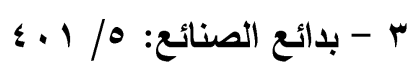

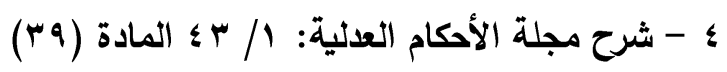

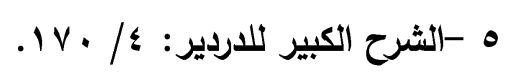

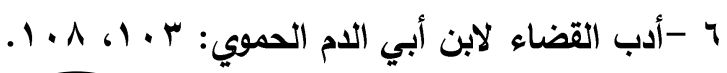


ومنهما نب إليه أبو بوسفمن أن جريمة قطع الطريق (الدر ابة) تتمق في

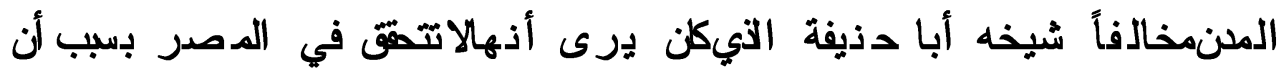

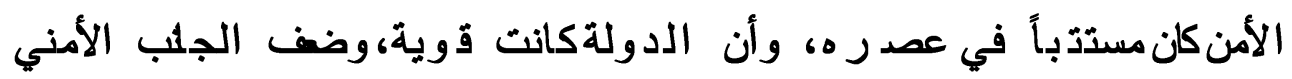

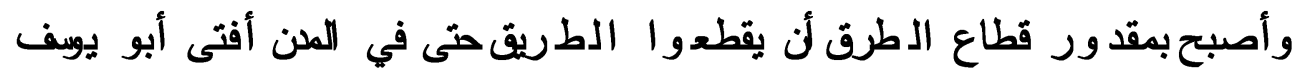
بـلك.

ومنهاكظك بيع الوفاء حيثكن الناس في السلق بـرضون القض الصسنبكذرة

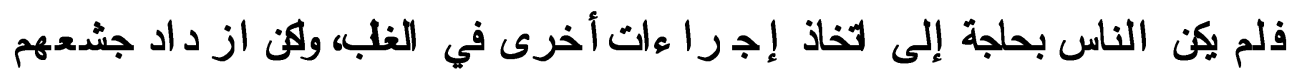

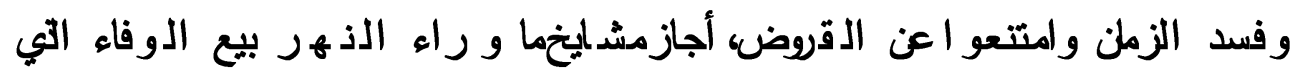

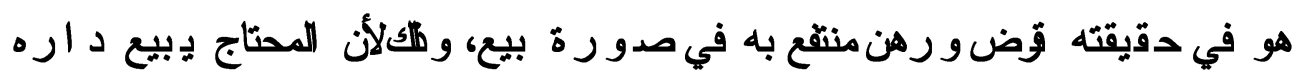

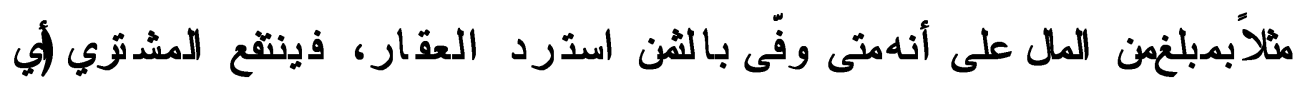

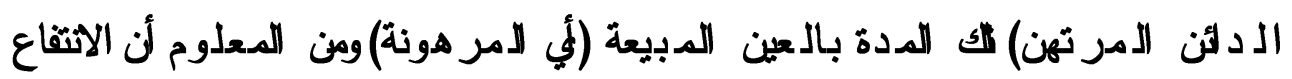

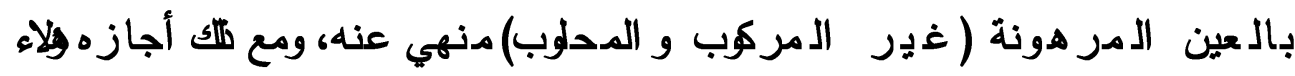
الفقهاء لفساد الزمان و الحاجة.

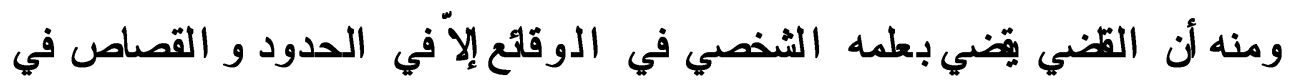

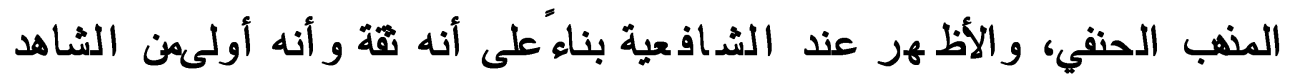

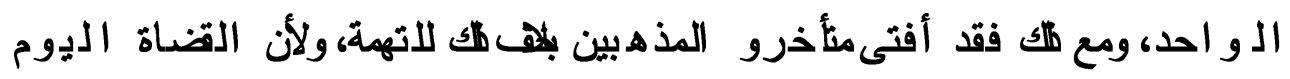

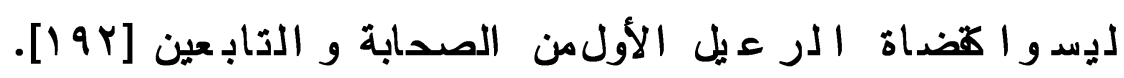

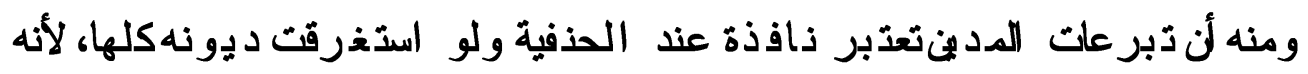

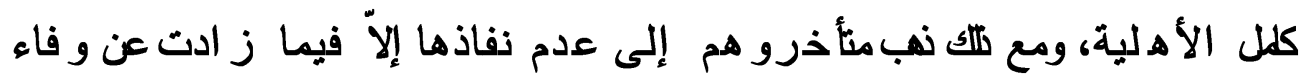

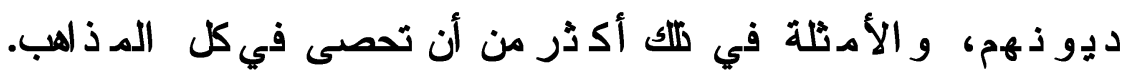

-الإقناع وشرحه كشاف القناع: ؟/ ؟ ؟ ؟ . 
و أفتى الإمامان: أبو حذيفةوملك، بجو از دفع الزكاة إلى الهاشمي (لئمن

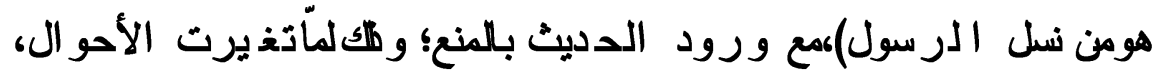

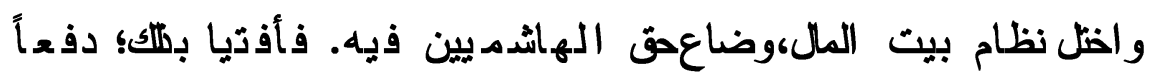

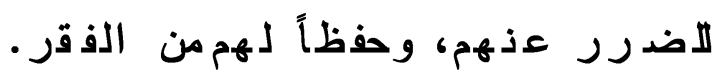

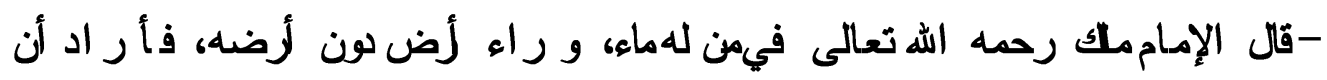

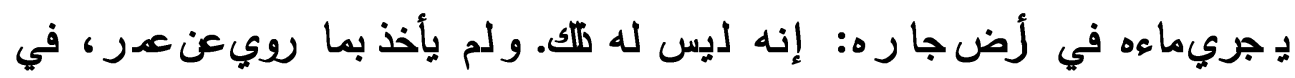

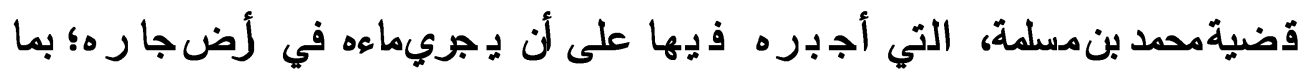

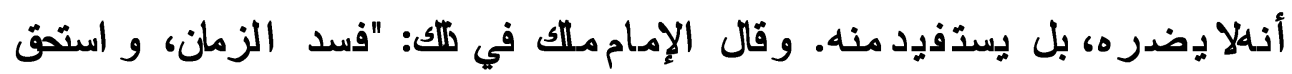

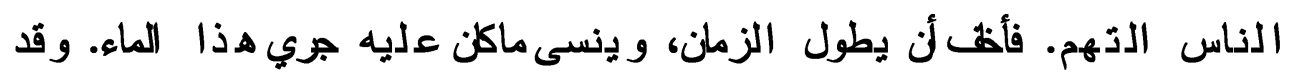

$$
\text { يدعي جارك عليك به دعوى في أرضك". }
$$

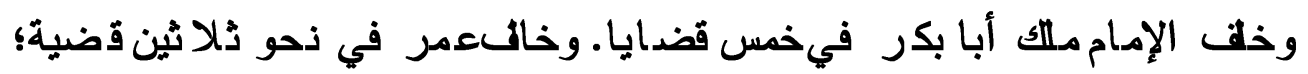

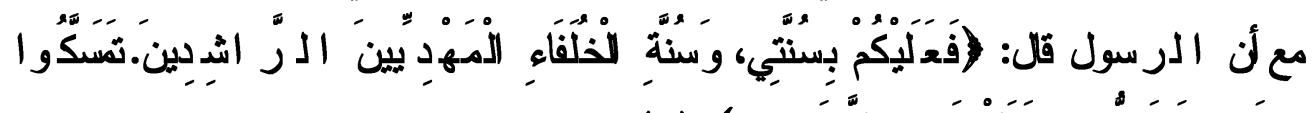

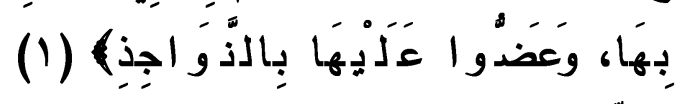

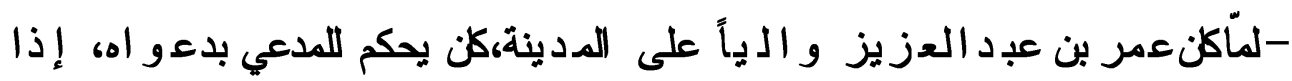

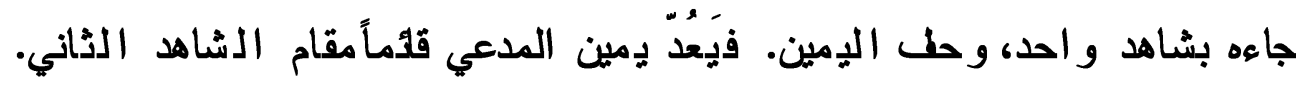

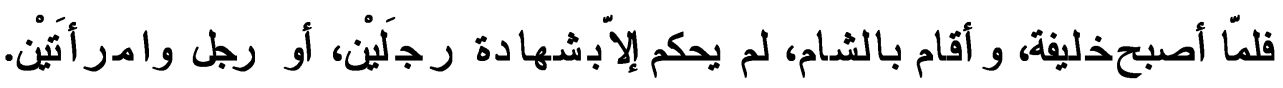

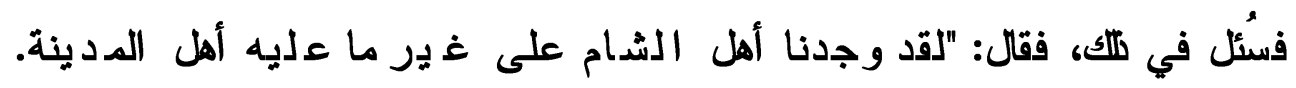
و الأخذ بتغير الزملن بدأمنذعصر الصحلبة_رضدون الله عليهم ـ فالرسولصصلى الله

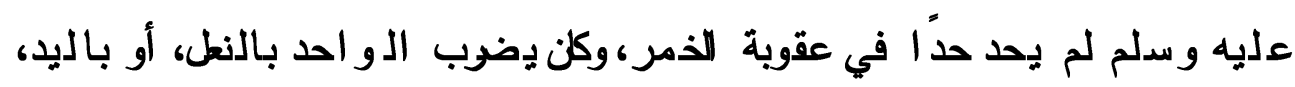

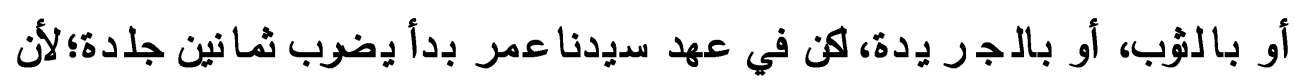

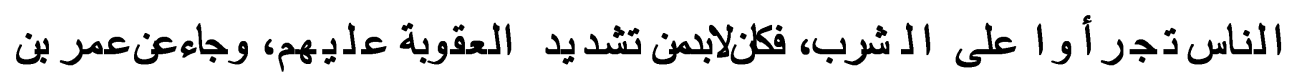


عبد العزيز رحمه الله تعالى قوله: تحث للناس أُضية، بقدر ما أحدذو امن الفجور

وفي زماننا هذا حث فيه تغ ير هلل فهزك أشياء التضت ليضاً التشديد، مثل فطل

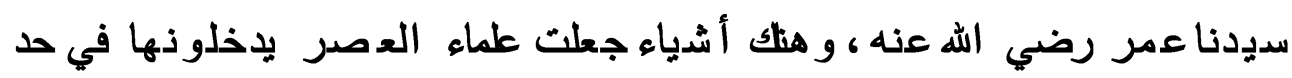

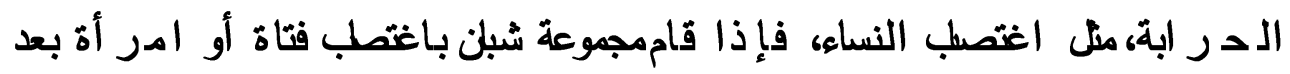

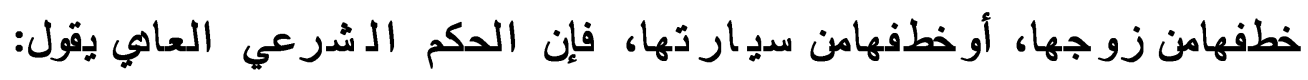

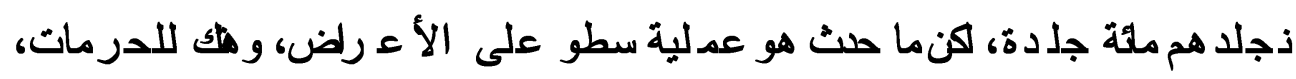

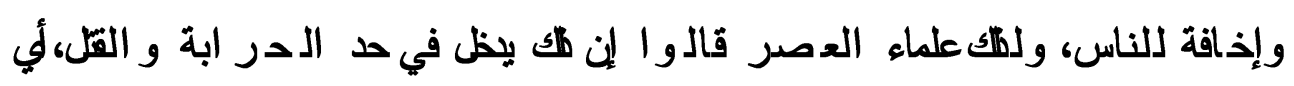

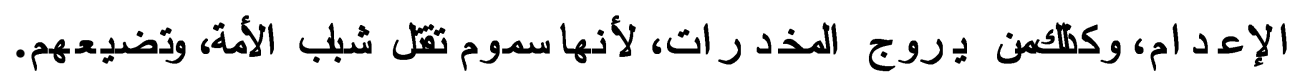

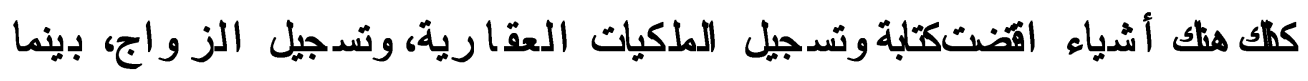

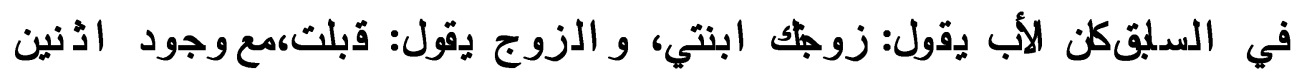

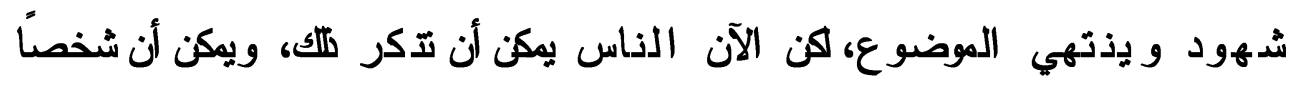

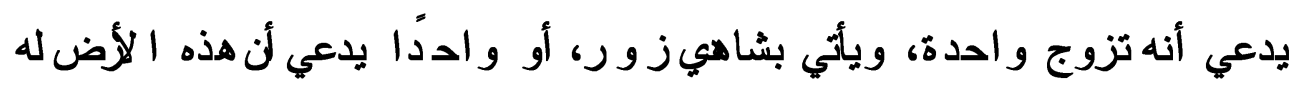

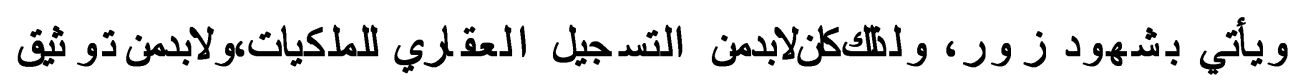

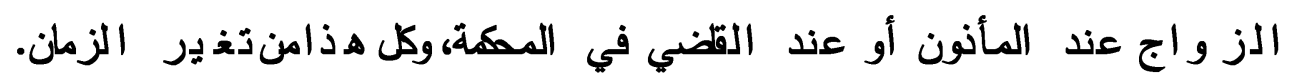

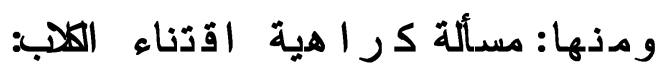

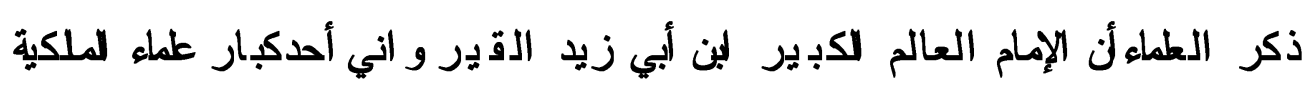

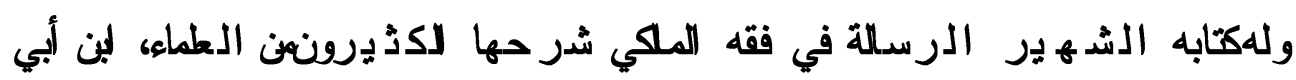

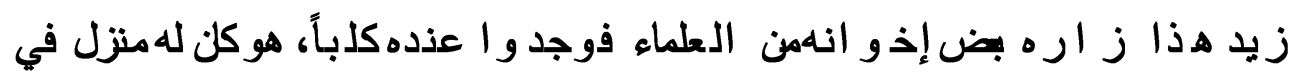

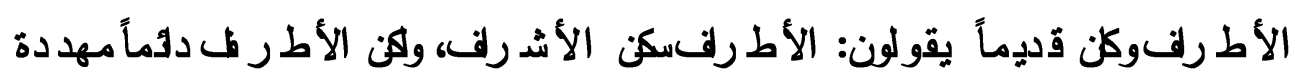

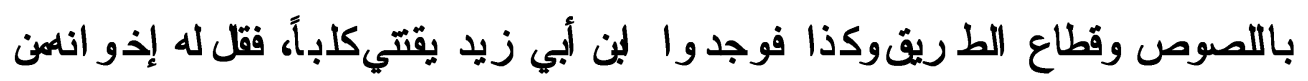

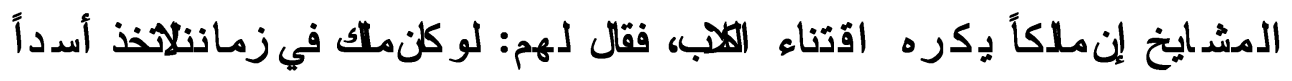


ضار ياً، و الكمهن أجل الحمايةمن اللصوص ومن هذه الأشياء، فل هذا على أن هنك اعتبار تغ ير الزمن في تغ ير الفتوى، تغنغ ير حاجات الناس في مثل هذه.

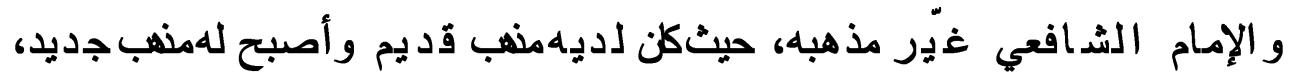

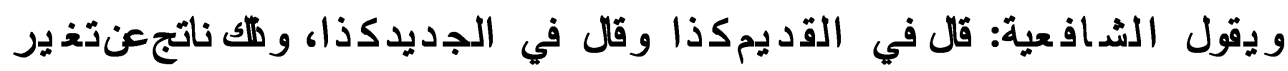

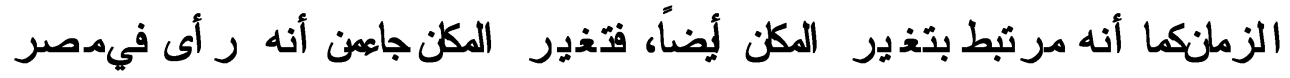

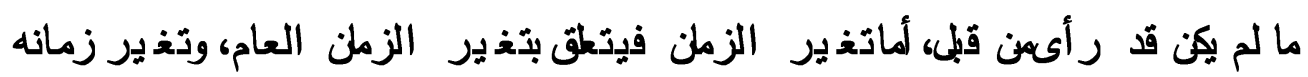

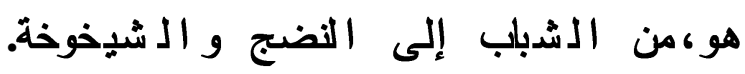

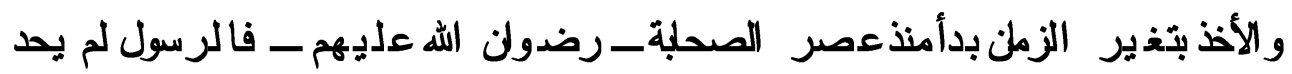

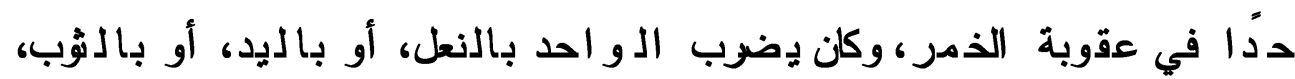

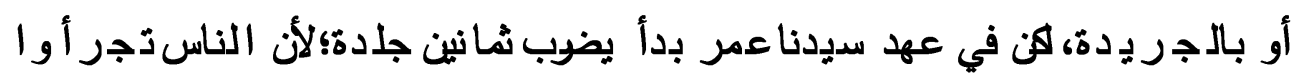

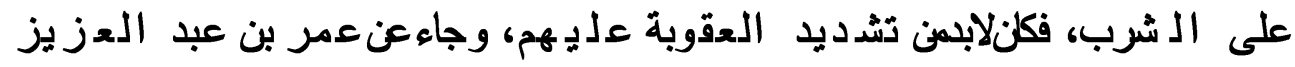

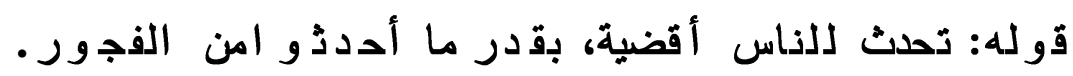

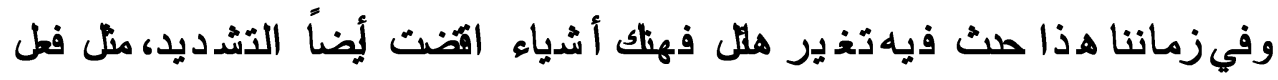

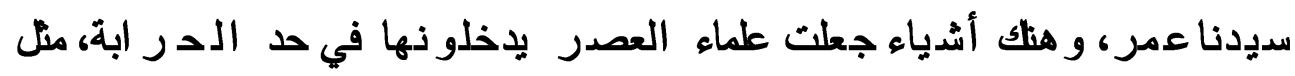

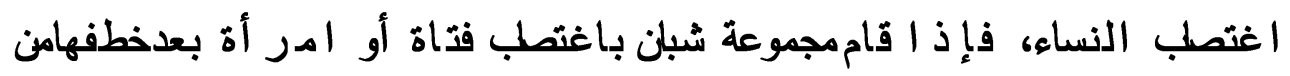

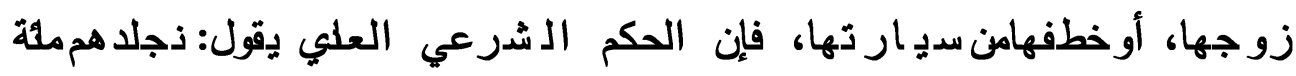

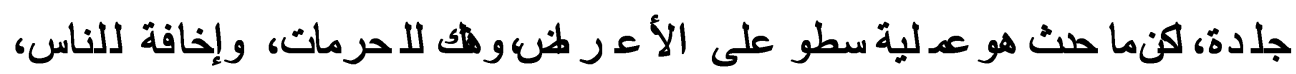

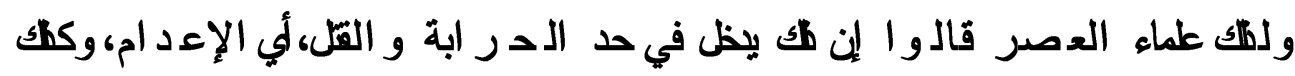

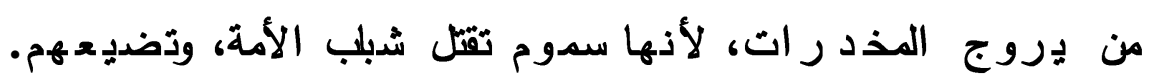

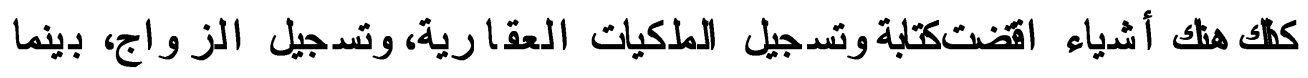

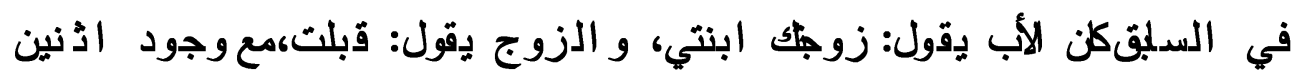

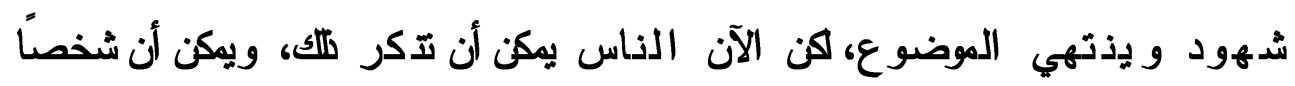

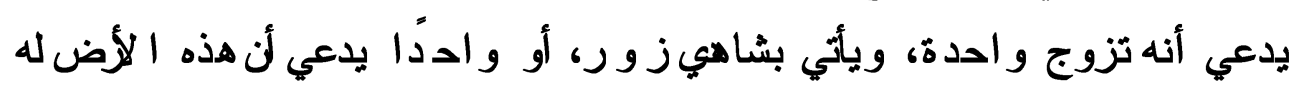




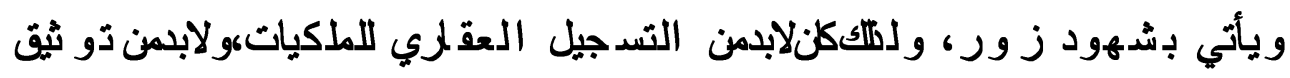

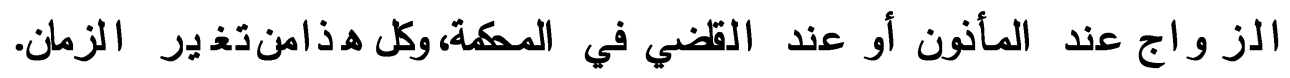




\section{䀦}

السبب الثاني: تغير المكان

معنى تغ ير المكن: هو اختلافه، إما بالثه بلد المسلمين، أو بالثه الد ار: د ار الإسلام، و د ار غ ير الإسلام، فكون الإنسلن يعيش دلخلمجمعمسلم، فإن المجمع

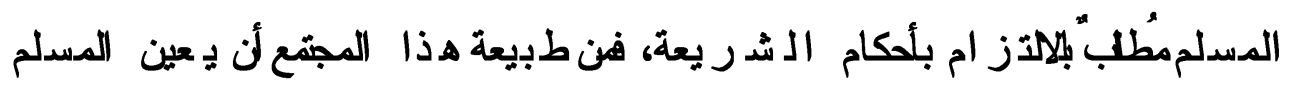

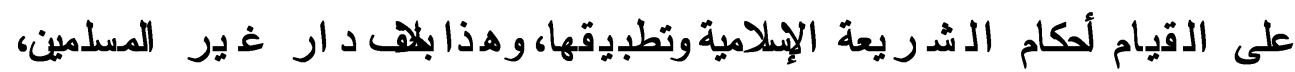

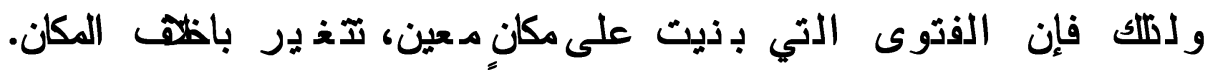




\section{المبمث الثالث}

\section{السبب الثالث: تغير العادات}

العادة هي الفعل التي بـكر ره الإنسلن، ويذرج عنه بيسر و سهولة،وممظم حياة

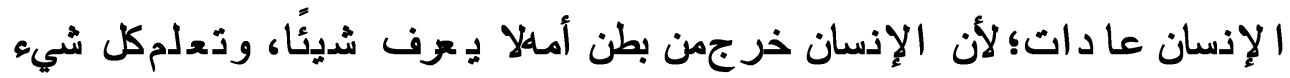

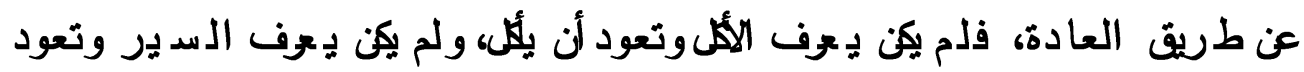

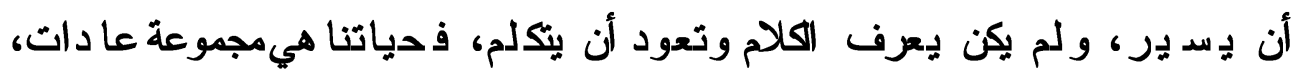

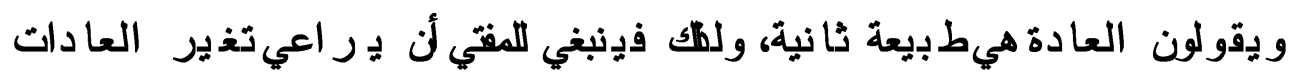

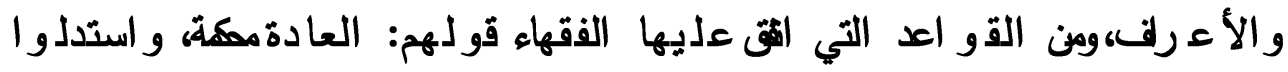

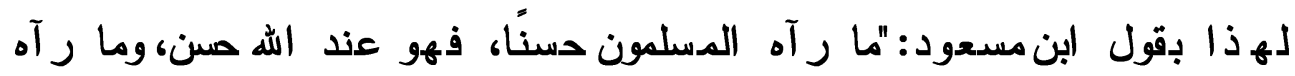

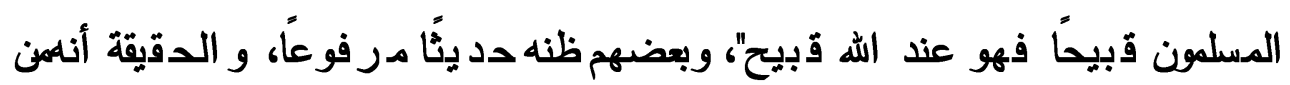

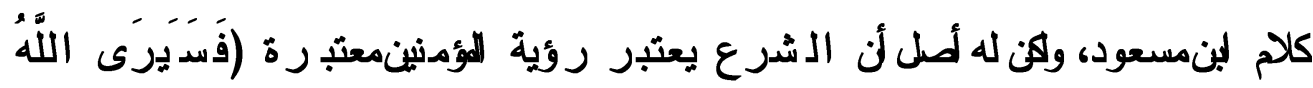

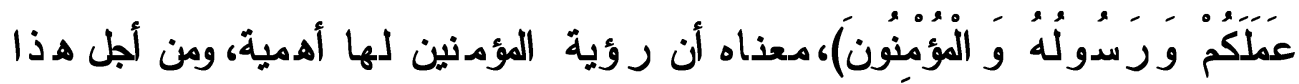

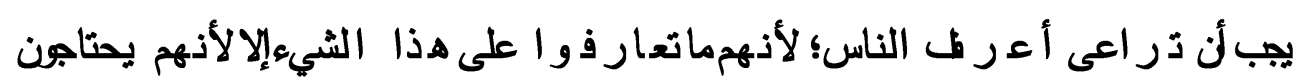

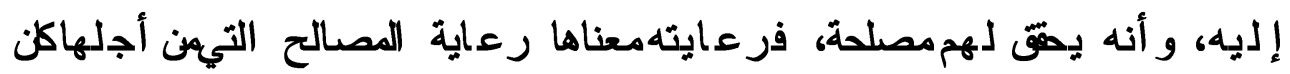

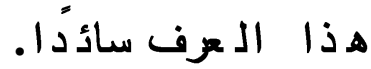




\section{المطلب الأول \\ معنى تغير العادات}

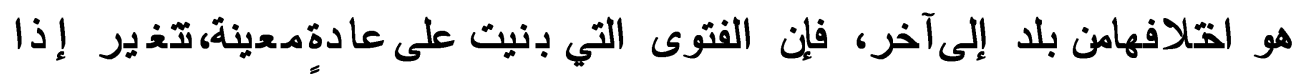

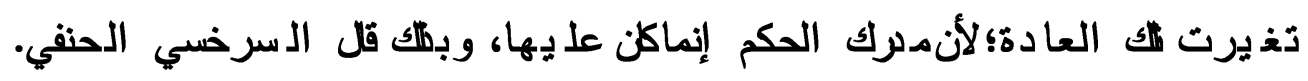
و قد بينّ صلمبكب أذو ار البدروف، وهومن الملاكية: أن المفتي إذا جاءه رجل يستفتيه عن لفظةٍ الألفاظ التيتذه بها البلدان، فلا يفذيه بحكم بلده بل هومن

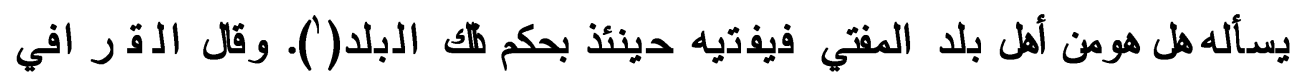

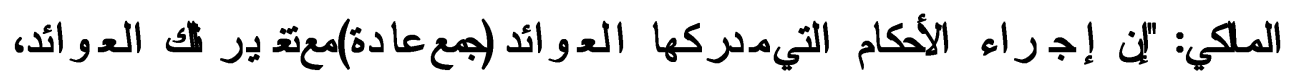
لمف الإجماعو جهالة في الدين، بلكلما هو في الـ شدر يعة يتبع العو ائد، يتغ ير الحكم فيه عندتغير العادة إلىماتثضيه العادة المتجددة، وليس هذاتجديداً

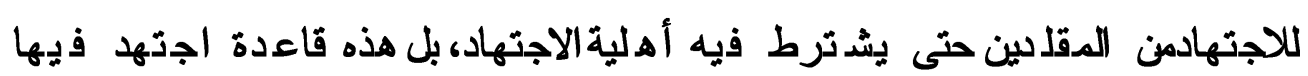
العلماء ولجمعو ا عليها فنمن نتبعهم فيهامن غ ير استئه اجتهاد". وقلا لئضاً:

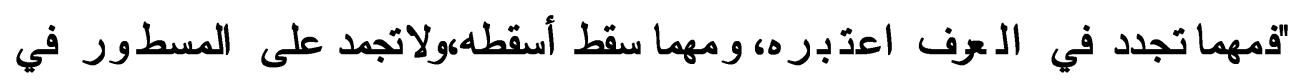
الكب طول عمرك... و الجمود على المذقلات أبد أضلل في الدين و جهل بمقاصد علماء المسلمين و السف الماضين، و على هذه القاءدة تذخرج أيمان الطق ودئ و العثىوصيغ الصدر ائح و لاكنايات، فقد يصدير الاصدريحكناية يفتر إلى النية". وقد طقّ لبن القيم علىماذكرته الملاكية في اعتبار هم لاعتف المتجد، فقل: "وهذا

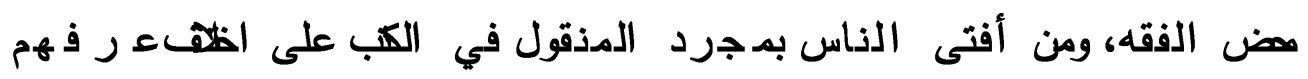

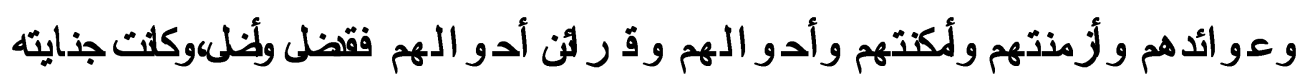


على الد دين أعظممن جنايةمن طبب الناس كلهم على اخثقبلادهم وءو ائد هم

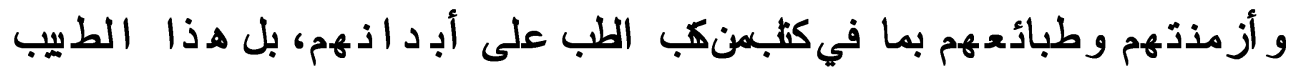

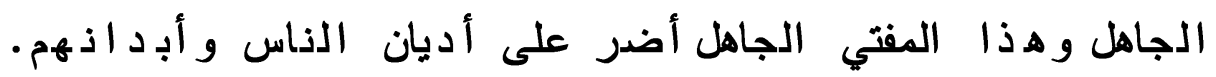


المطاب الثاني

أمثلة على تغير الفتوى بتغير العرف

ما لويعنملك أنه قال: إذا تنازع الزوجان في بضض الصدداق بعد الدخول، أن القول قول الزوج،مع أن الأصل عدم البّ. و علّ القلضي إسماءيل(') هن فقهاء الماكية- على لآك بقوله: هذهكانت عادتهم بالمدينة: أن الرجلا

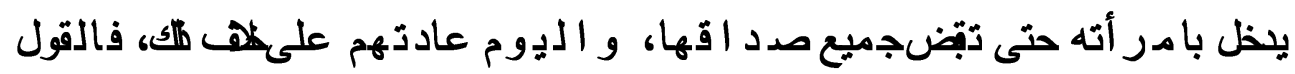

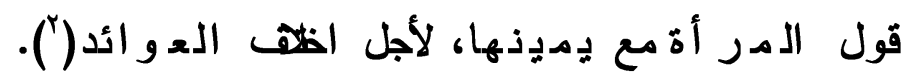
إذا قاللامر أته: أنت على حرد ام أو خلية أو بدرية أو مو هبثك لأهك:

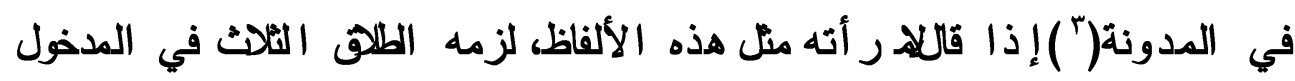

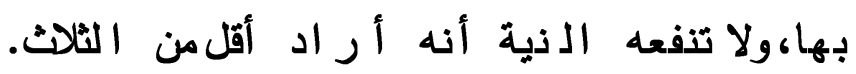

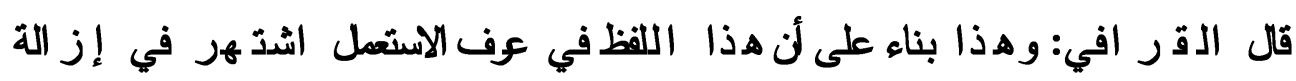
العصمة، و اشدذهر في العددد الذى هو الثه الثلاث.

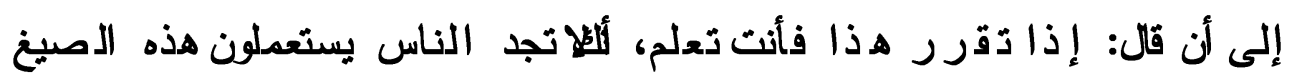

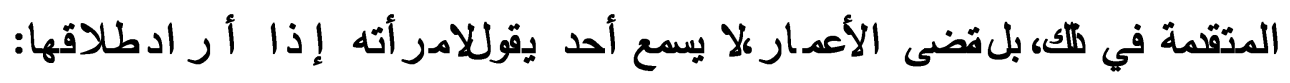

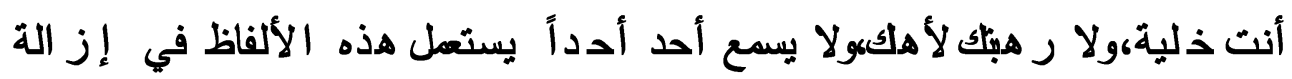
عصمة،ولا في عدد طلقات، فال عرف حيذئذ في هذه الألفاظ مق قطعاً (أ).

' - القاضي أبو إسحاق إسماعيل بن إسحاق بن حماد البغدادي، ولد عام . . . اهـ، وتوفي عام

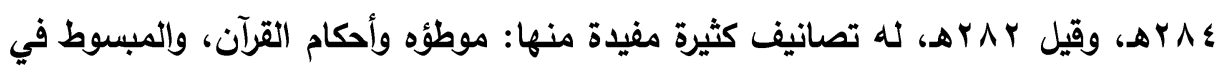
الفقه ومختصره، وكتاب في الفرائض، وشواهد الموطأ وغيرها. ترجمته: شجرة النور الزكية،

$$
\begin{aligned}
& \text { ص: ه ז، ترجمة رقم (ه) (ه). }
\end{aligned}
$$

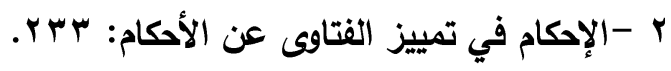

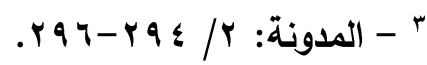

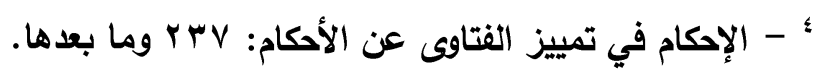


وقال في موضع آخر : (ومن لك لفظ الدر ام، و لذلية، و الب رية، ونحوهامما هو

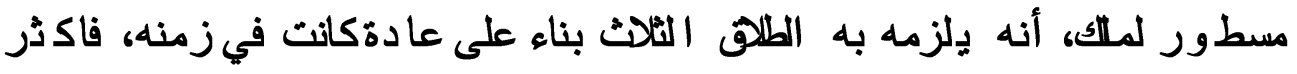

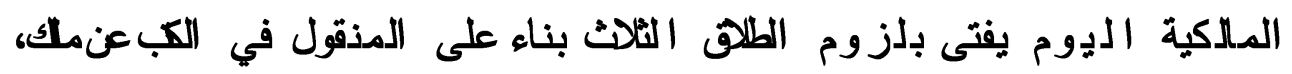

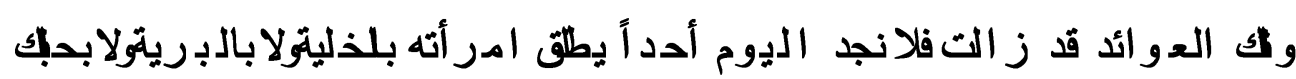

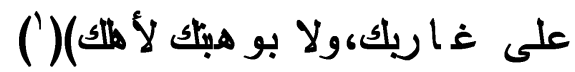

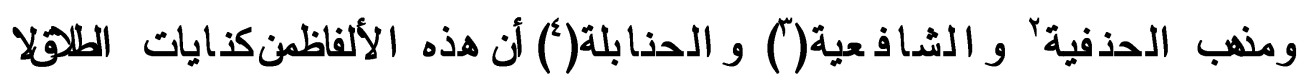
يقع بها الطلاق إلا بالذية.

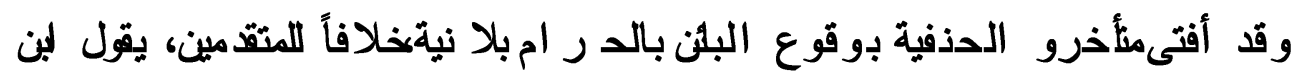

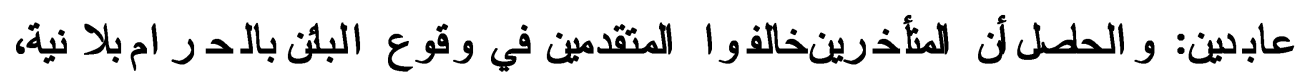

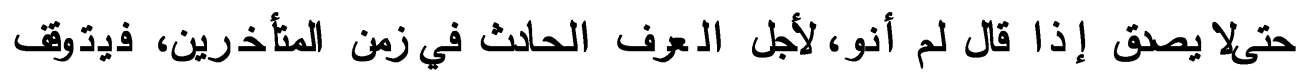

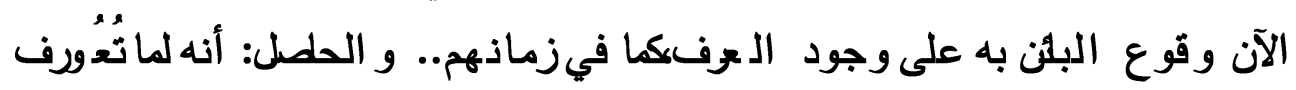

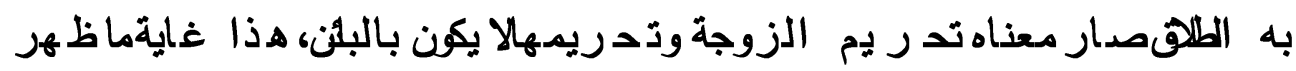
لي في هذا المقام ()).

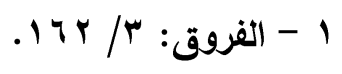

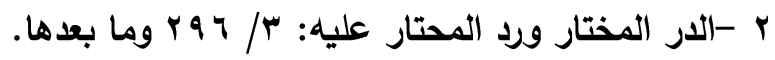

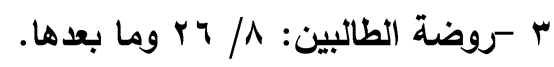

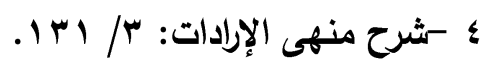

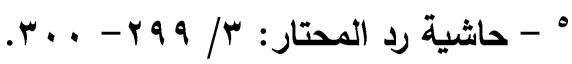




\section{المطلب الثالث}

\section{ضابط تغير الفتوى بتغير العرف}

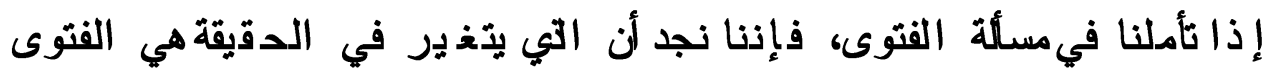

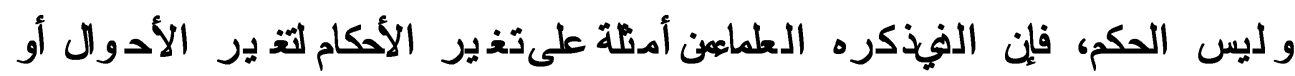

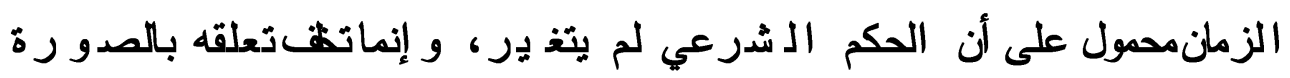

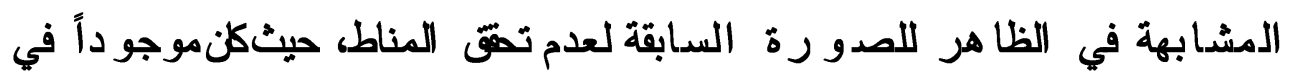
الصدو رة السابقة وغ ير موجود في الصو رة اللاقةه،ومثل طكحكم النقة و السكن

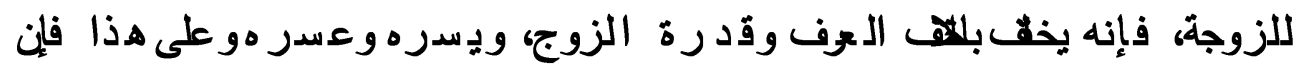

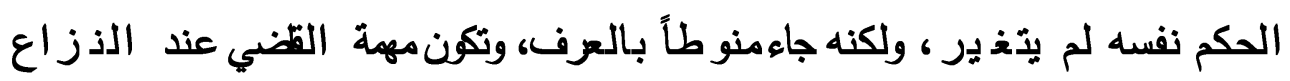

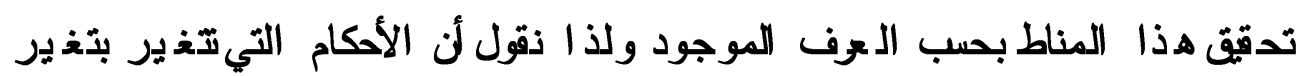

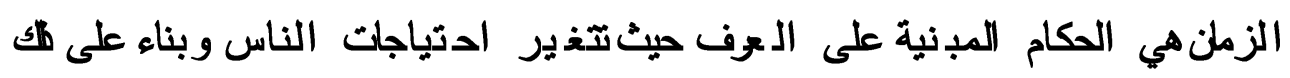

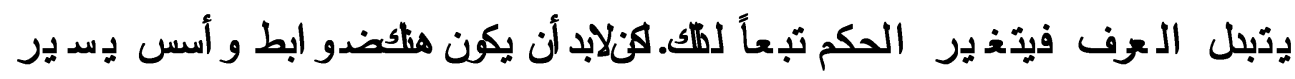

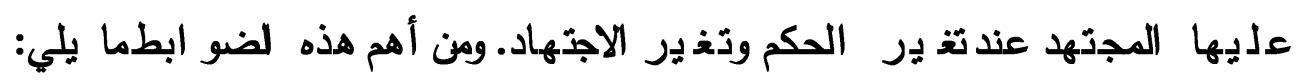

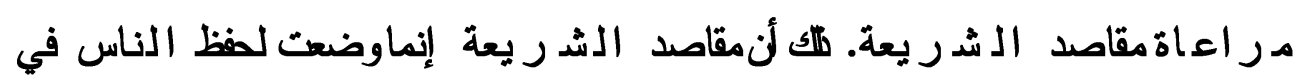

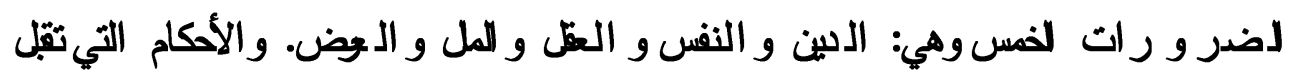

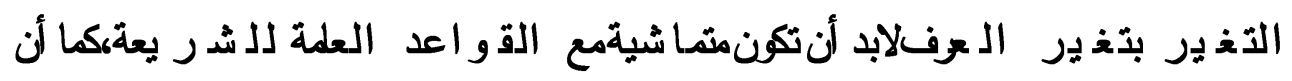

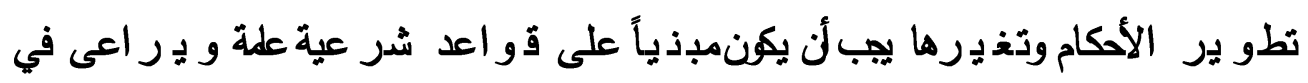

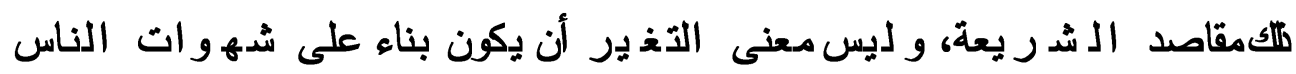

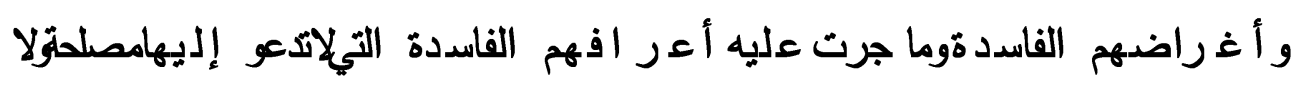

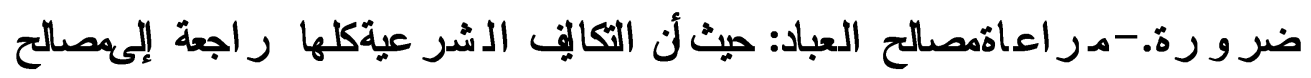

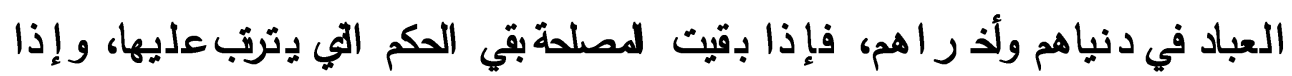

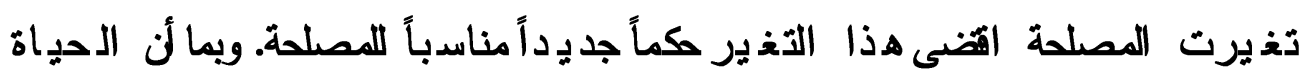


في تطور مستمر وهذا التطور سببلتغير أعرف الناسمنزمن إلىىخر، فيما

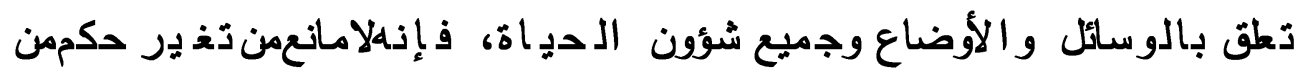

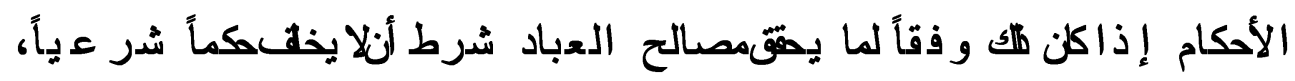

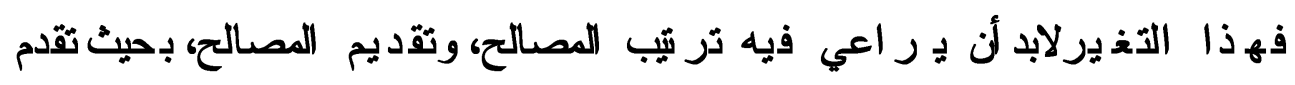

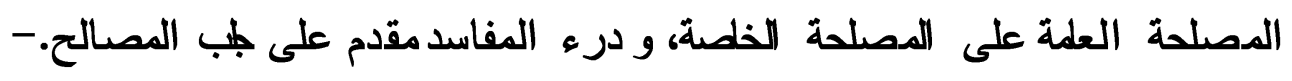

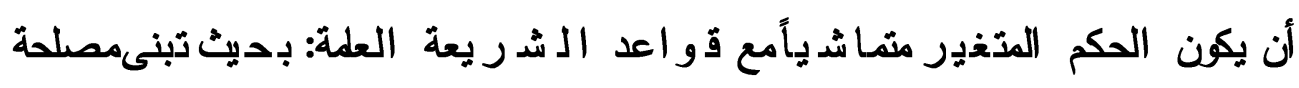

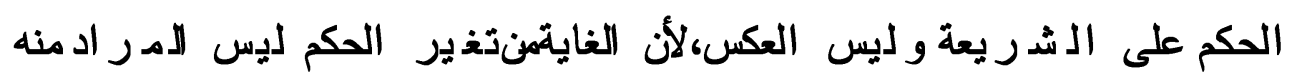

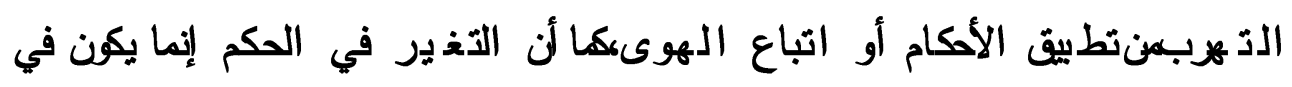

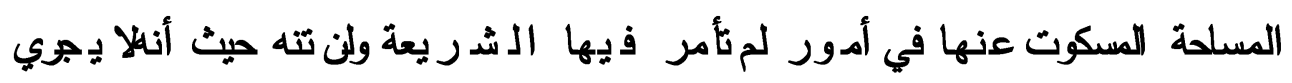

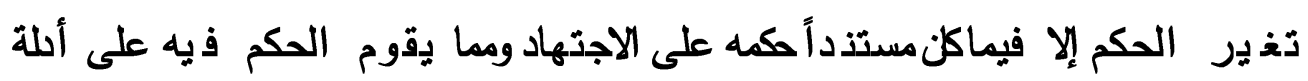

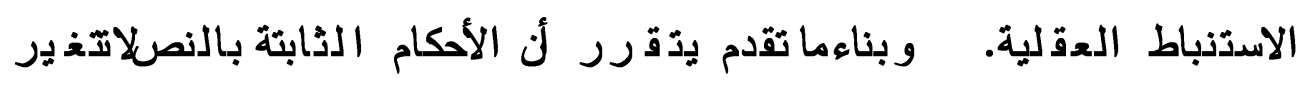

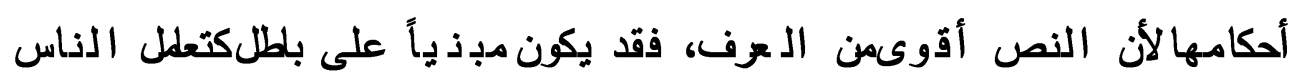

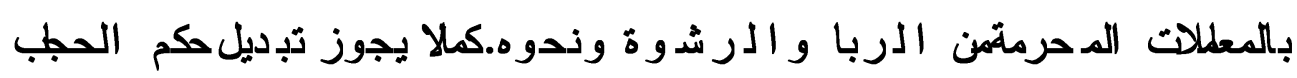

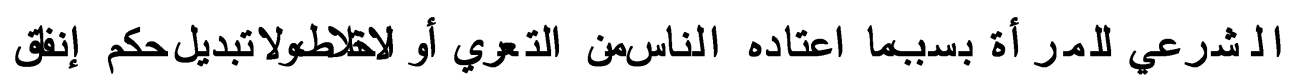

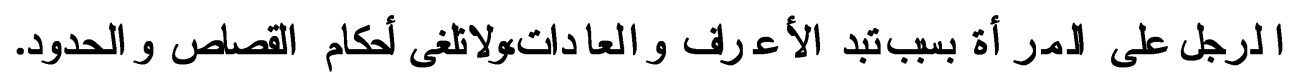

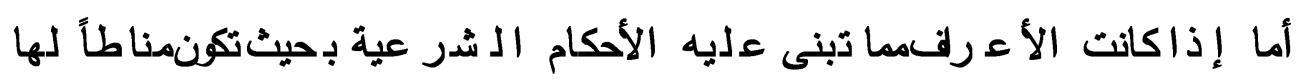

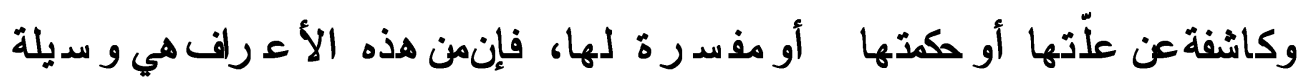

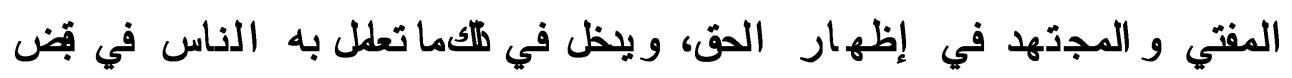

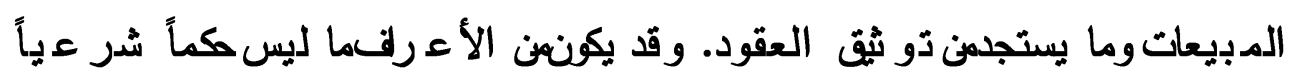

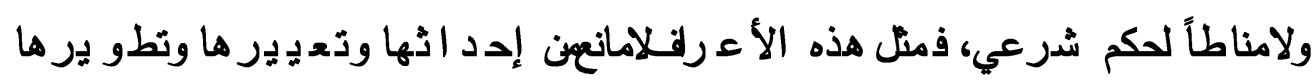

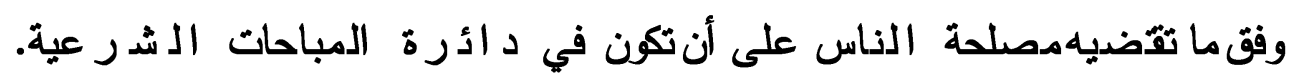

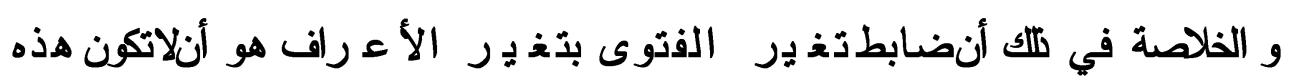

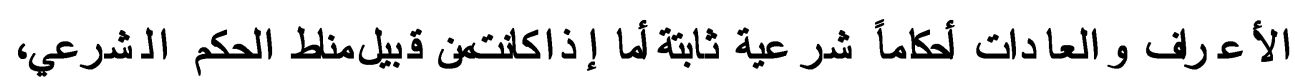


أوكاتت ليستهن قبيل الحكم الـشرعيولامناطه فهذه الأعرف و العادات ذر اعى عند الذظر والاجتهادككا يجب على المتهر الثكلكن استمر ار بقائها قبل إصددار

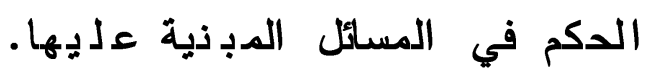




\section{الإلب الرابع}

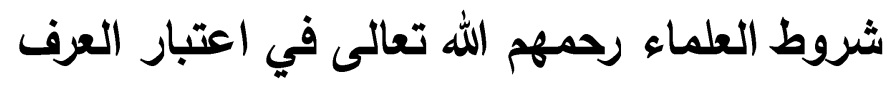

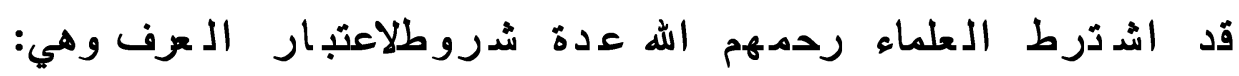

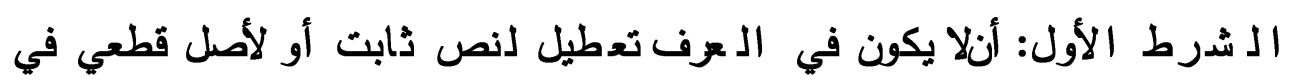

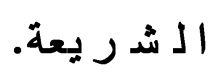

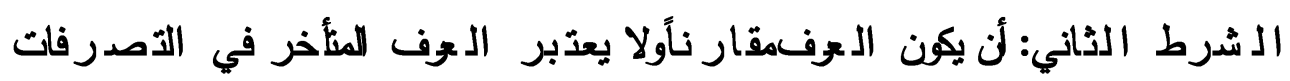

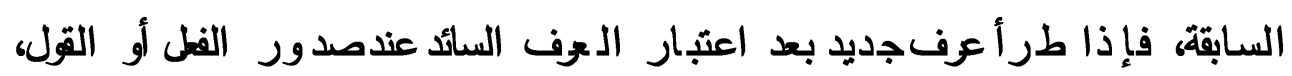
فلا بعذّبر هذا العرف.

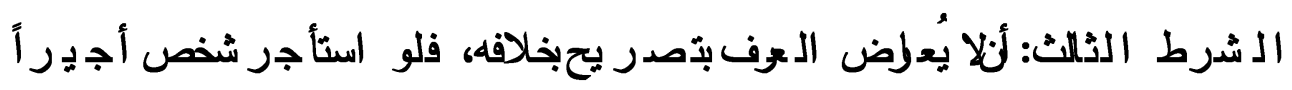
للعلهن الظهر إلى العصر فقط ليس له أن يلزمه بالعلهن الصباح إلى المساء

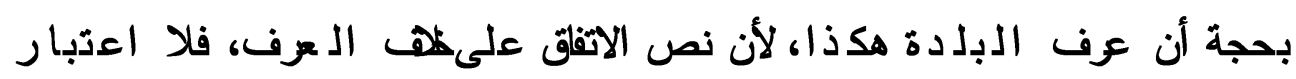

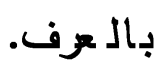

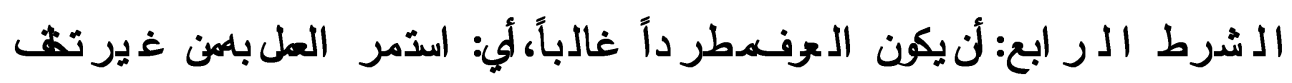

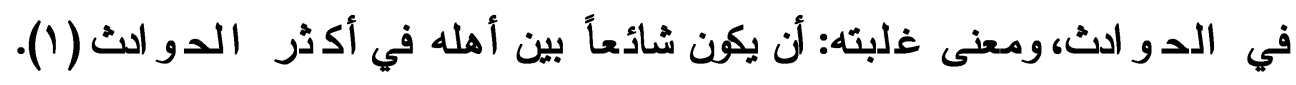

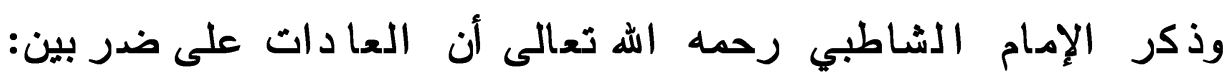

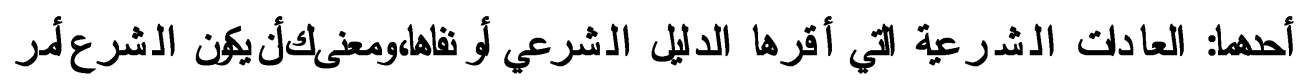
بها إيجاباً، أو ندباً أو نهى عنهاكر الهة أو تد ريماً أو أنن فيها فهلها فيلاً أو تركاً.

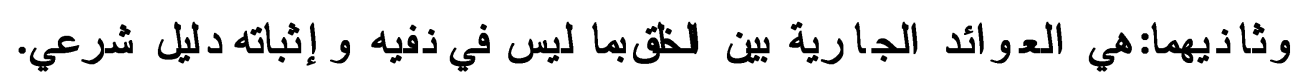

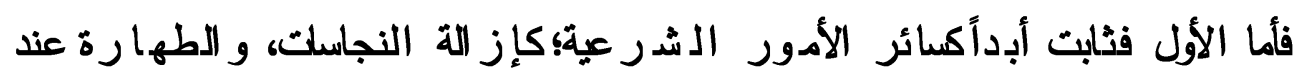

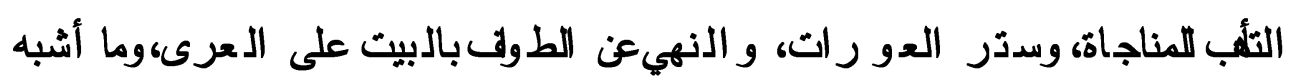

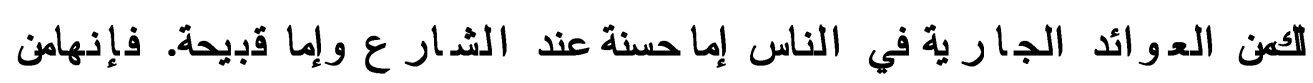

' - انظر: تغير الفتوى لمحمد عمر باز مول: 9 ؛. 
جملة الأمور الداظلةتصت لككام الـ شرع، فلاتبديل لها، وإن اختلت آراء المكافن ف بـها.

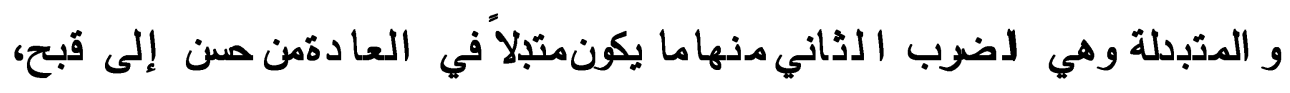

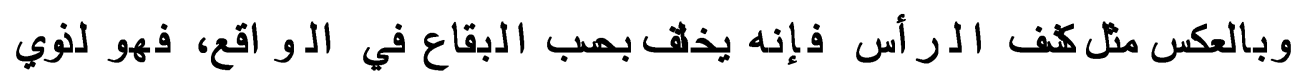

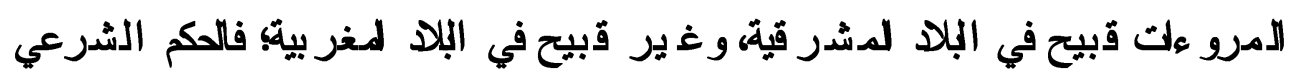

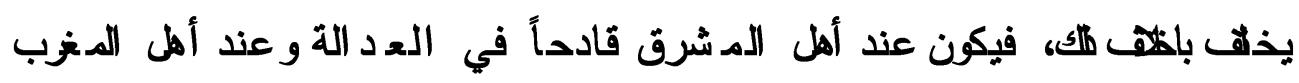
غ غدر قدادح.

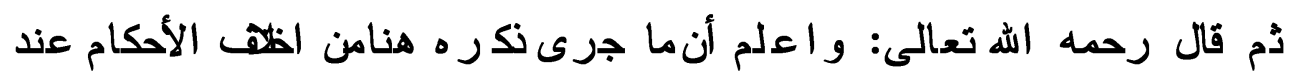

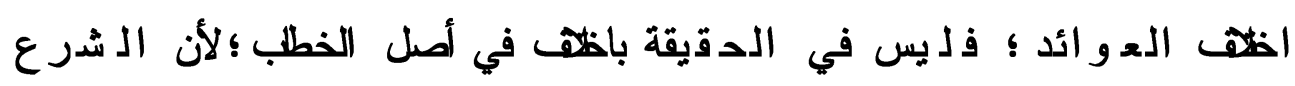

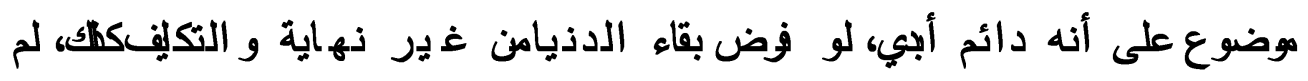

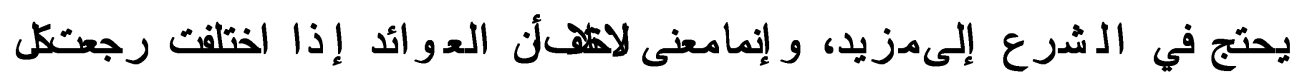

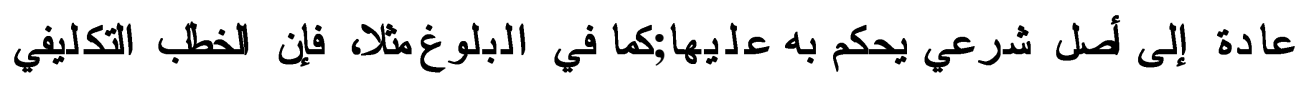

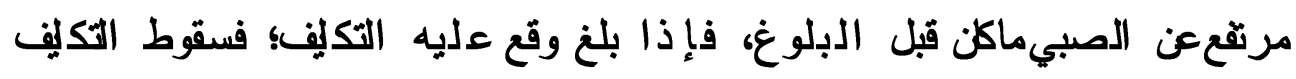

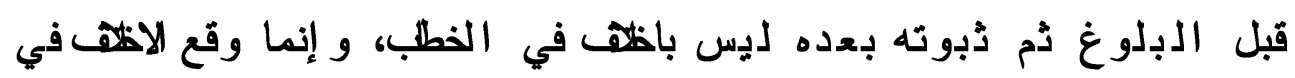

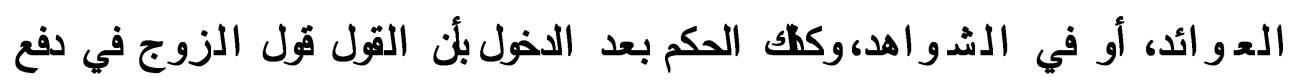

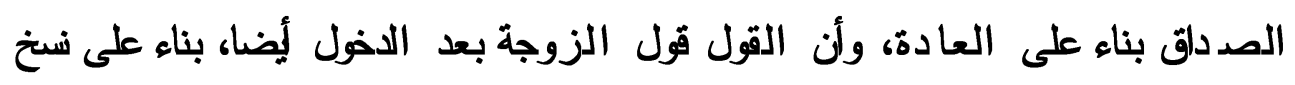

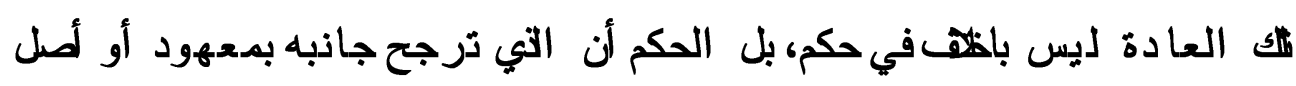

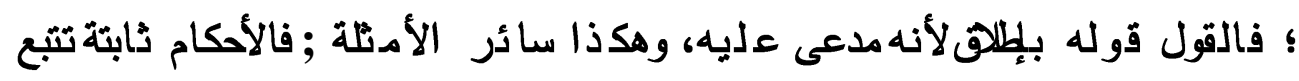

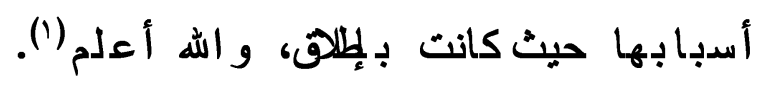

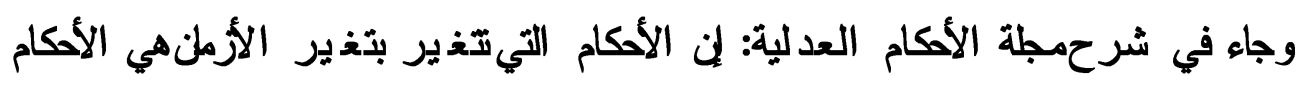

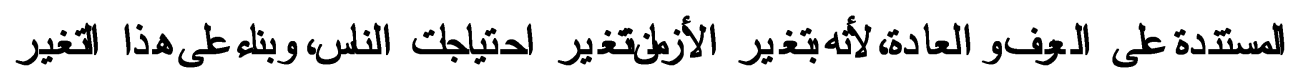

1 -انظر: الموافقات في أصول الأحكام: جـ/9 19 19 19، 199 بتصرف يسير. 


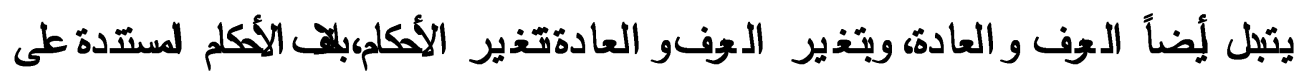

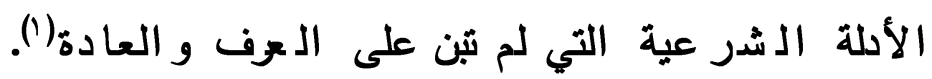

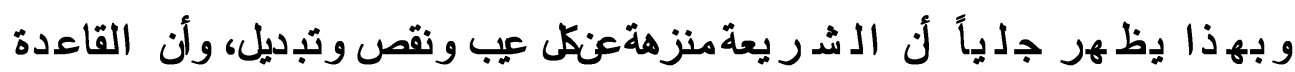
المذكو رة من محلسن الـ ش ر بعة وملائمتها لكل زمان ومكان. 


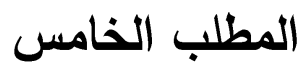

\section{أمثلة على تغير الفتوى بتغير العرف}

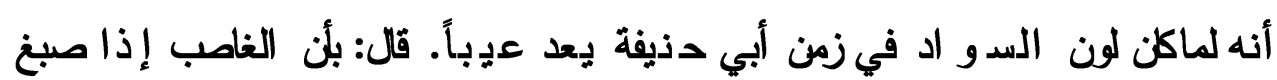

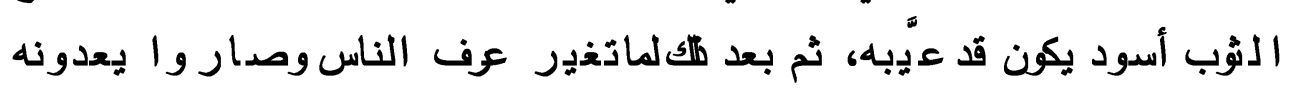

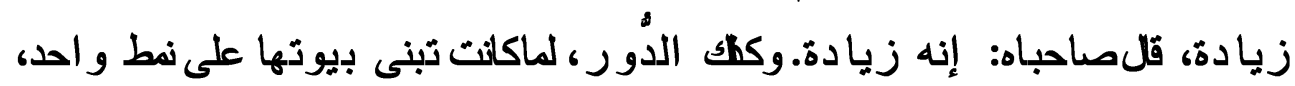

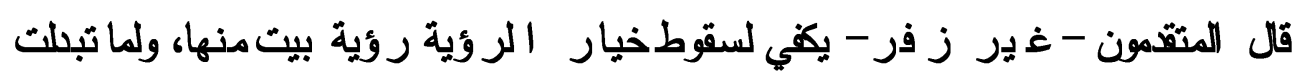

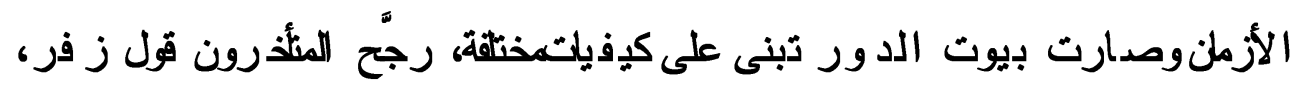

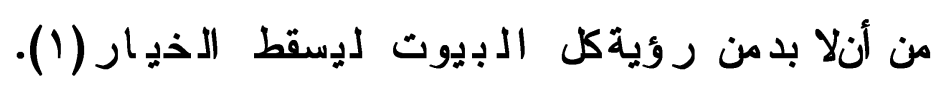

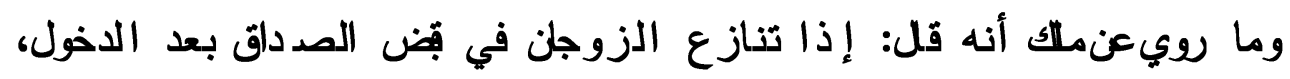

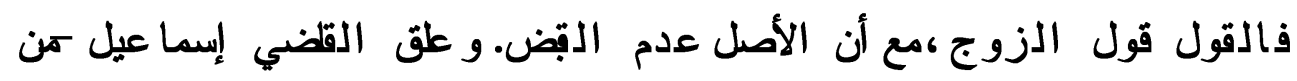

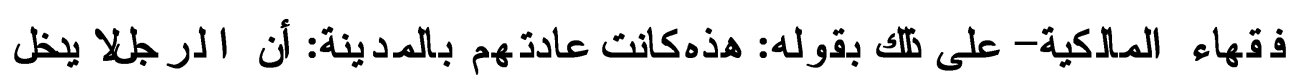

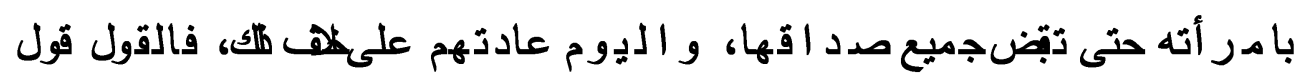

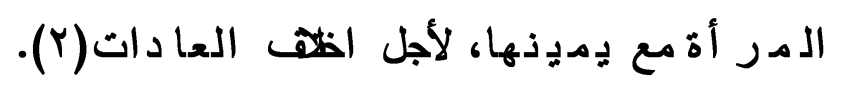

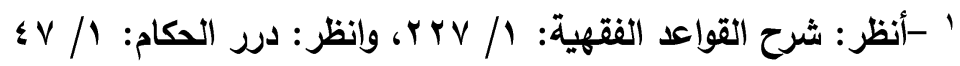

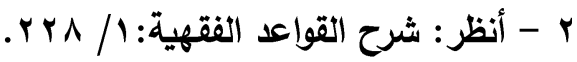




\section{口المبمث الرابع}

\section{السبب الرابع: تغير الأحوال}

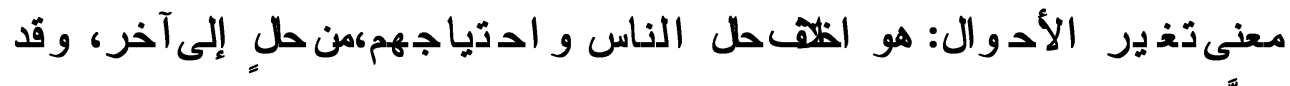
نص" الإمام ابن القيم على أن يكون المفي و الحاكم علىمعرفة بأحو ال الناس، وإلا

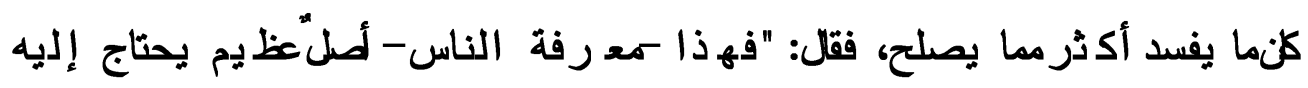
المقي و الحاكم، فلإن لم يكن فقيها فيه فقيها في الأمر و النهي ثم يطبق أحهما على الآخر، وإلامنما يفسد أكذرمما يصلح، فوإنه إذا لم يكن فقيها في الأمر له معرفة بالناس تصدور له الظالم بصدو رة المظلاوم وعكسه، و الممق بصدو رة المبطل وعكسه، و راج عليه الدكر و لذداع والاحتيل، وتصدور لله الزذديق فيصدورة

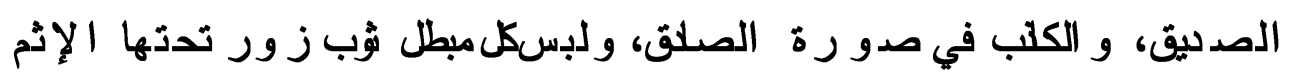
و لكب و الفجور، وهو لجهله بالناس وأحو الـهم وعو ائدهم و عر فياتهجلا يميز هذامن هذا، بل ينبغي له أن يكون فقي وهاً في وعدرفةمكر الناس وخداءهم و احتيالـهم

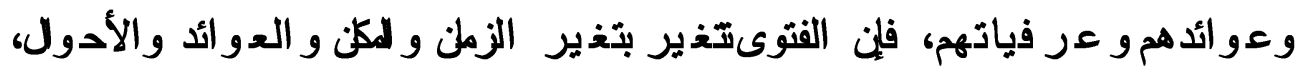

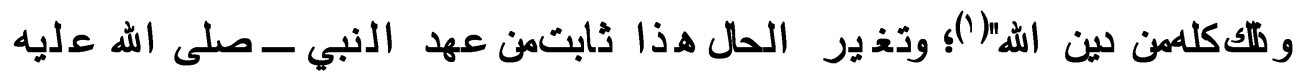
و سدلم - حيث إنهكن يفتي هل حل بما يناسبه، وقد سأله رجل رهن القبلة للصائم فأجاز له، وسألهآخر فمنعه، فلما بحث الصحابة وجدو أن أن الذي أجاز للهكن

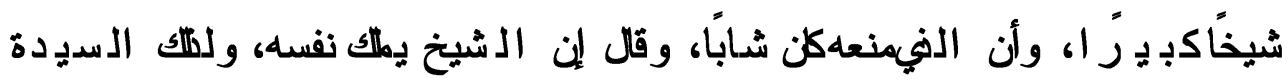
عائشة لما قالت إن الذبيكان دُقبل و هو صائم، قالت: وكان أمهكم لأربه، وأي واني ضابطًا لذفسه..

فقد روى رعن عبدالهابن عمرو بن العاص، - رضي الله عنهما- أنه قال: لاكنًا عند النبي -صلى الله عليه وسلم- فجاء شب، فقل: يا رسول الله أقبل و أناصائم؟

$$
\text { 1 - إعلام الموقعين عن رب العالمين: ه/ } 9 \text { هـ }
$$


قال:لا، فجاء شيخ، فقال: يا رسول الله، أقبّل و أناصائم؟ قال: ذعم، فنظر بعضنا

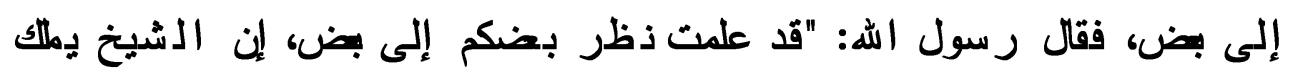

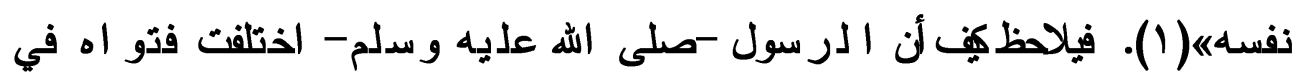

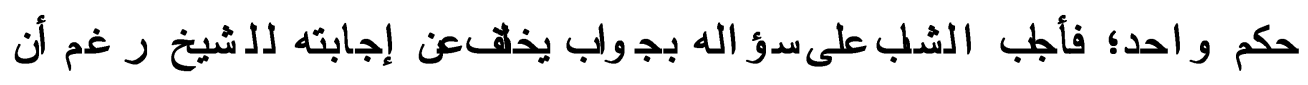

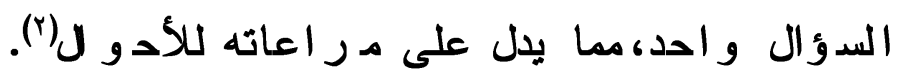

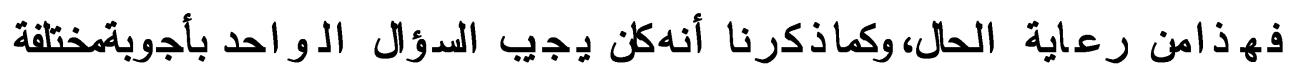

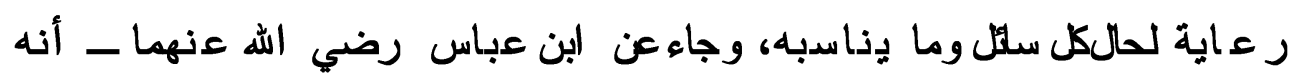

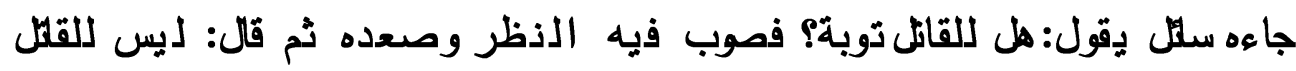

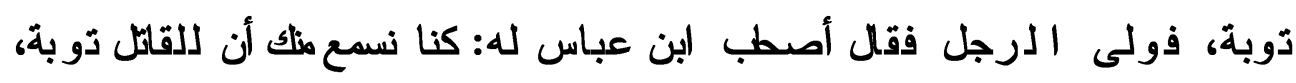

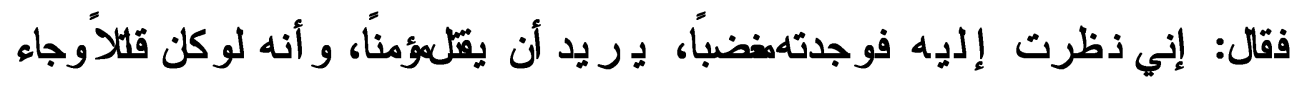

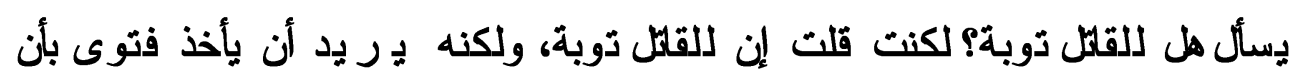

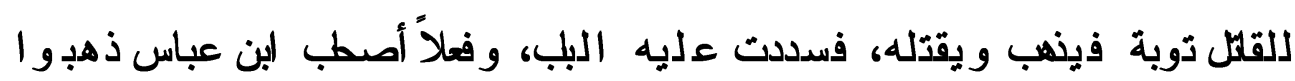

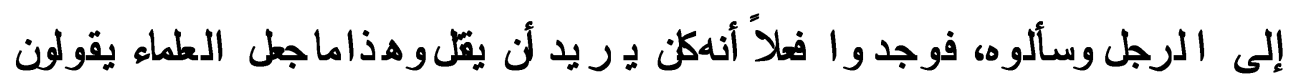

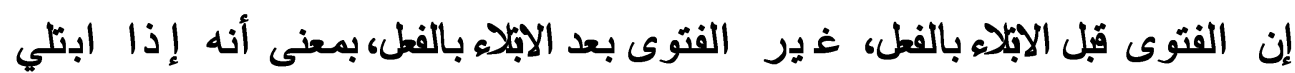

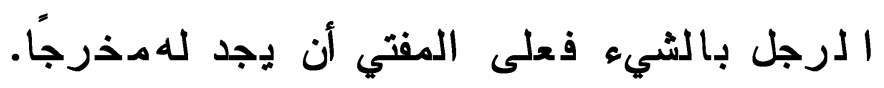

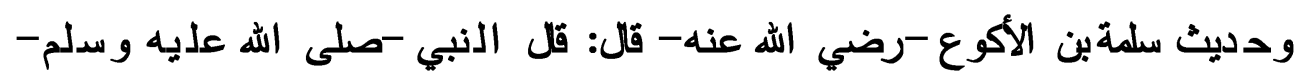

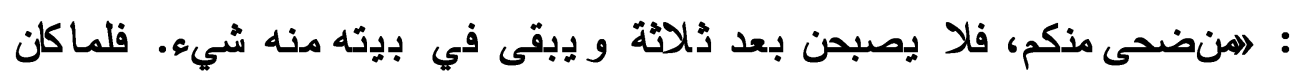

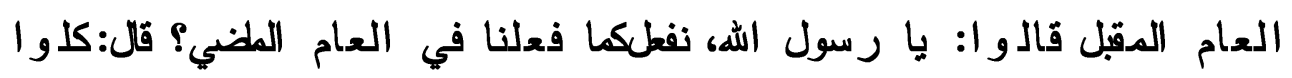

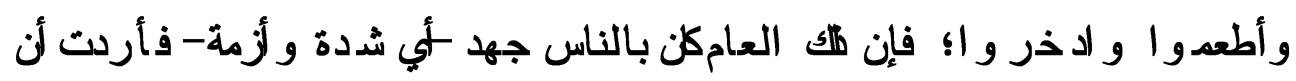

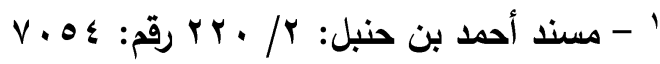

$$
\begin{aligned}
& \text { r - وذلك لاختلاف الحالين. }
\end{aligned}
$$




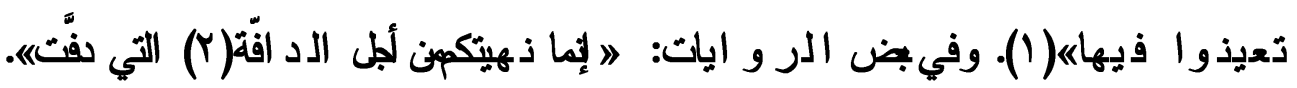

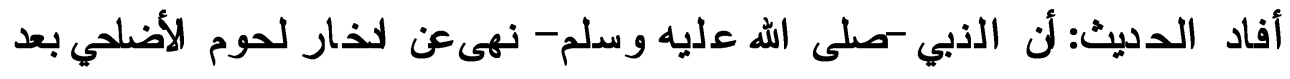

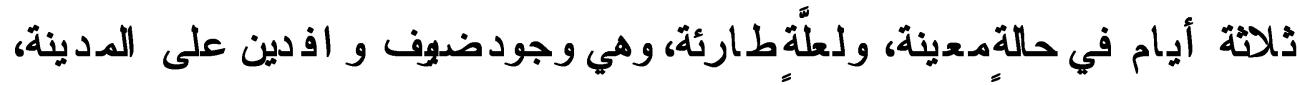

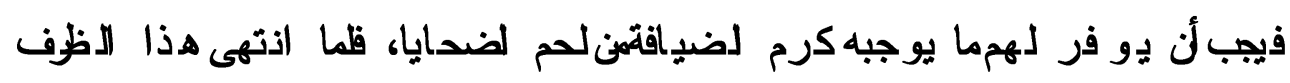

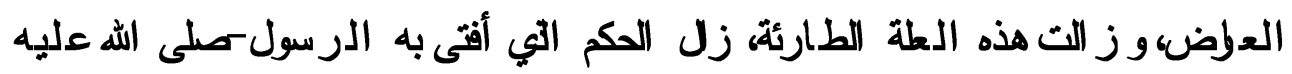

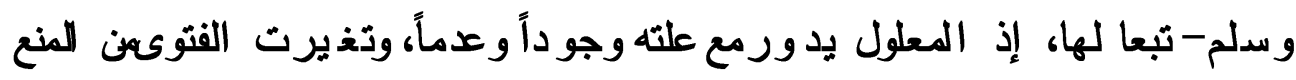

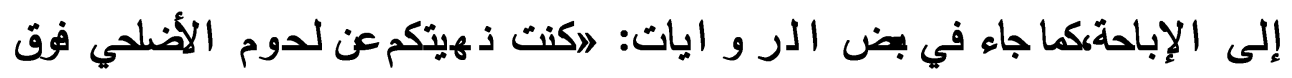

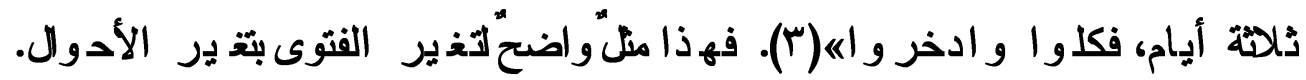

' - -

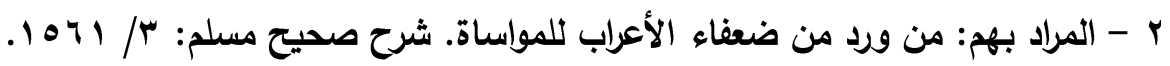

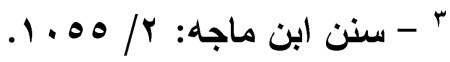




\section{المبمث الخامس}

تغ ير الفتوى لأسبب: ناجمة عن أفعال مباحة أو مذدوبة

المطلب الأول

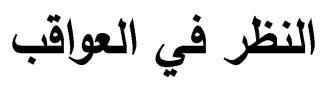

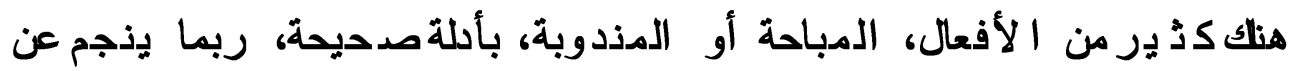

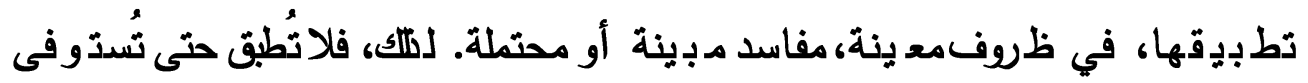

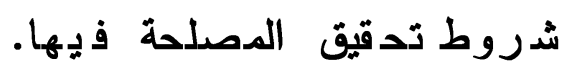

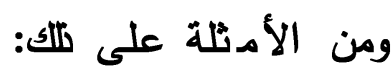

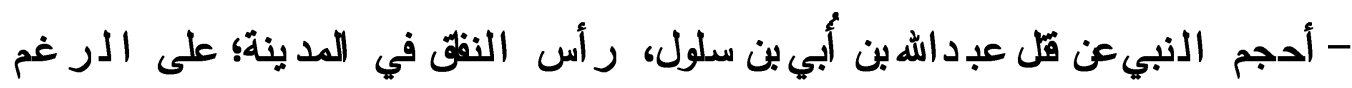

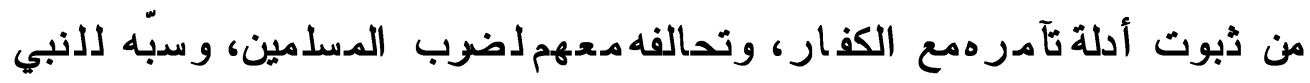

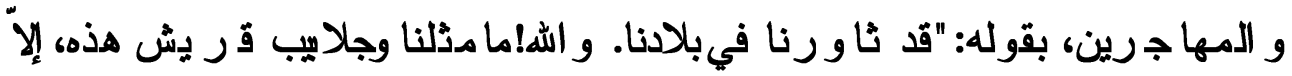

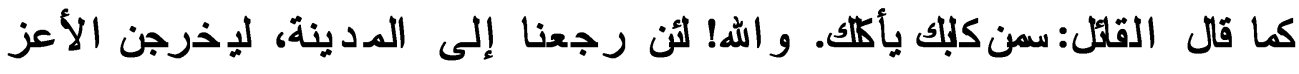

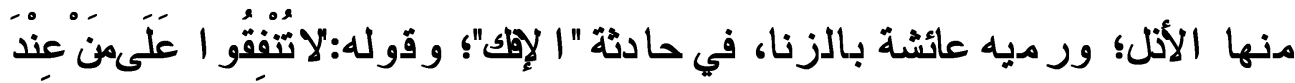

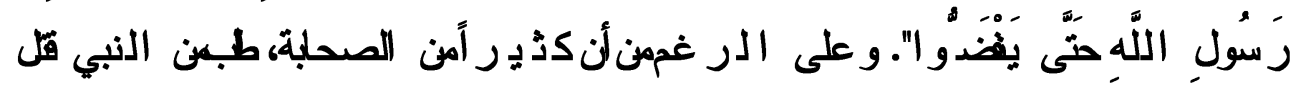

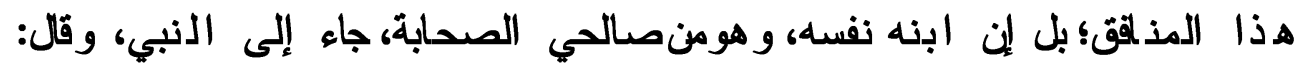

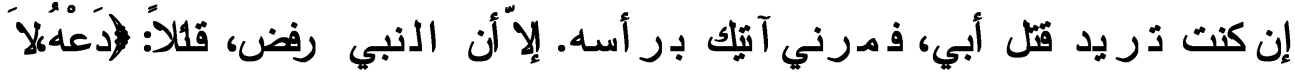

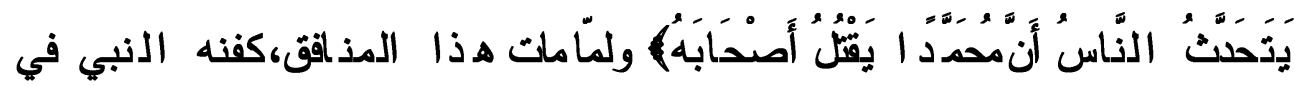

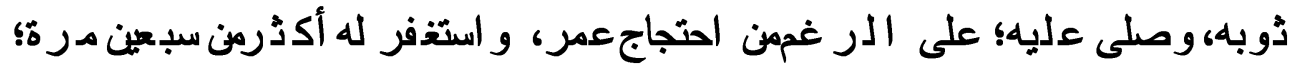

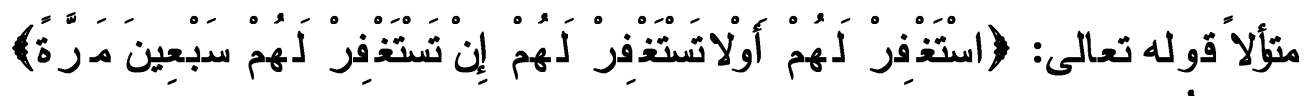

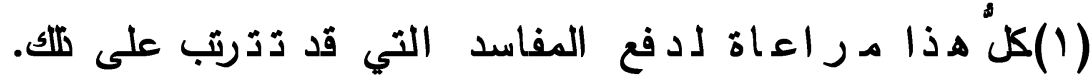


- شَكَتَ زوجة عب دالله بن عمرو منه، عند رسول الله صلى الله عليه وسدلم، بأنه يبالغ

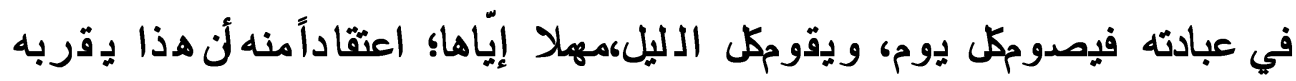

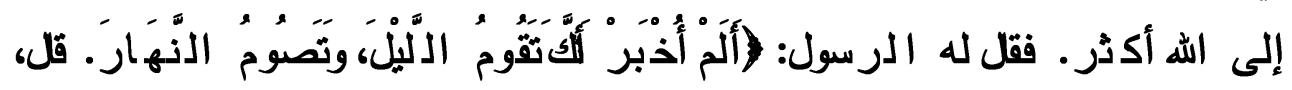

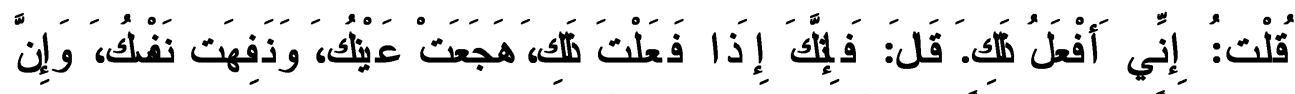

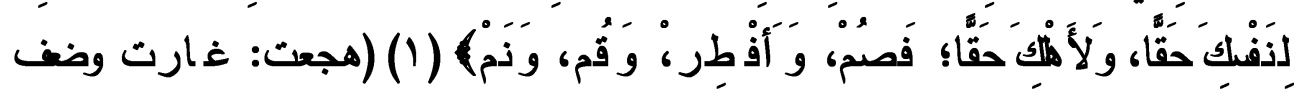

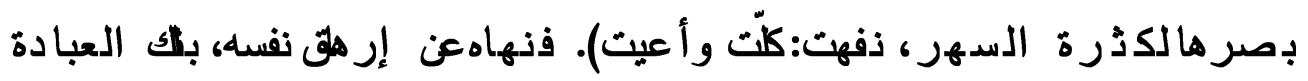

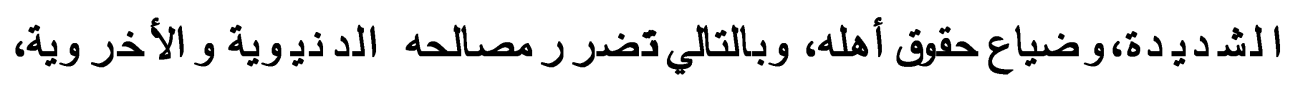

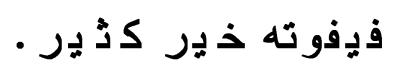

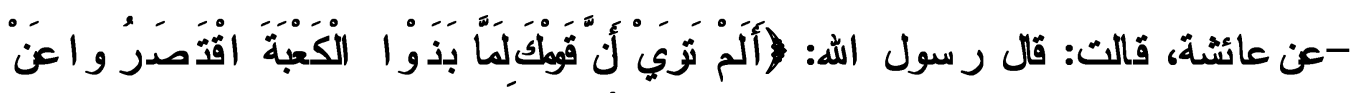

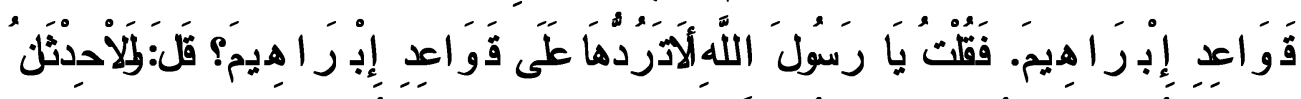

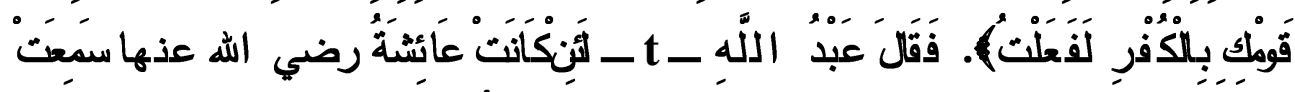

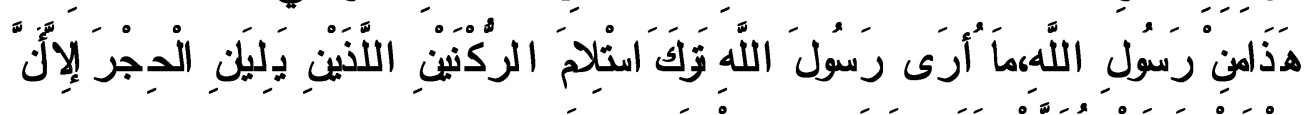

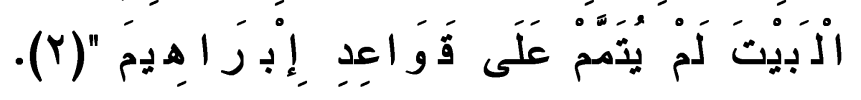

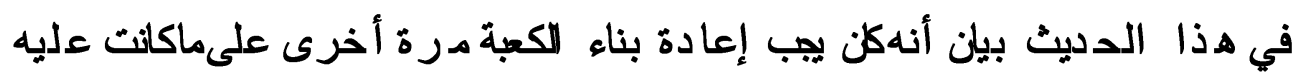

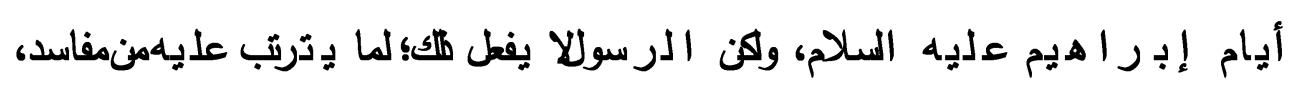

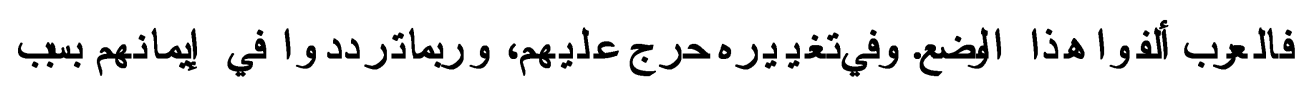
.5

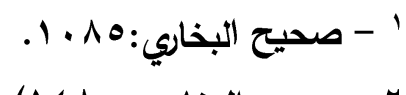

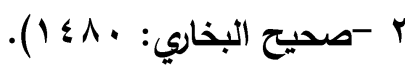


المطلب الثاني

\section{تغير الفتاوى لتفير نظرة المجتهد}

فقد يحث أن المجتهد قد رأى ر أياً فيمسلةمعينة، ثم ثضي الأيام فيظهر له منظلا أدلة أخرى، أو منظلا رؤية أوسع، أو منخلا ذع ر فه على المسألة

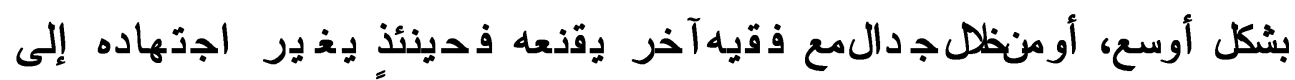

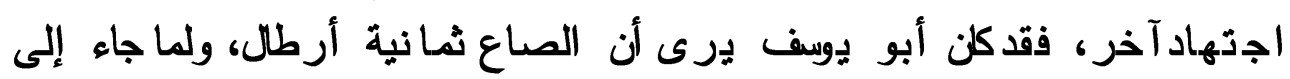
المدينة وذاقش الإمامماكاً، و وض عليه الصيعلن الباقيتهن عصدر رسول الله

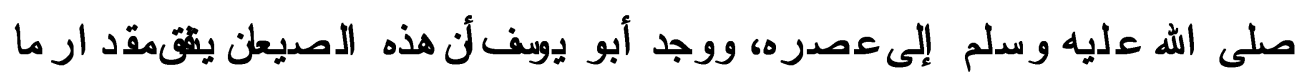
في يهامعما نب إليهماك رجععن ر أيه وقال بأن الصاع هوخمة أرطل و ثلث. و الإمام الثافعي غيَر معظم آر ائه القليمة إلى آر ائه الجديددة وليس السب فيكلها

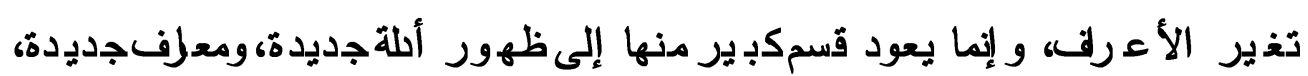
و إلى النضج الذي يدّم بعد الأربـ الأرين.

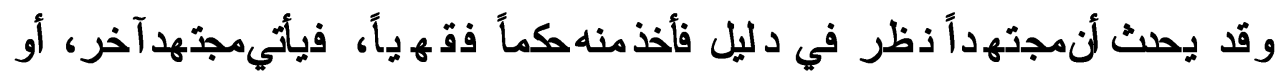
مجتهد منتب لمنهب الأول فيذظر في الد ليل نفسه فيستنبطمنه كماً آخر، أو

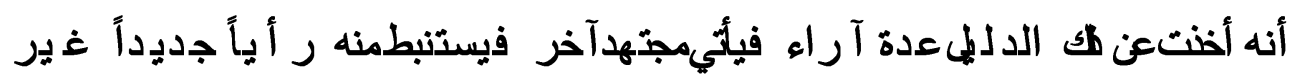
مسبوق لأي سبب كان. 


\section{المطلب الثالث}

\section{تشربع لحالة مؤقتة}

قالت عائة رضي الله عنها:ف (لي ذو افدو ا ببطء) الناسمن ألمل البادية، فدضرت

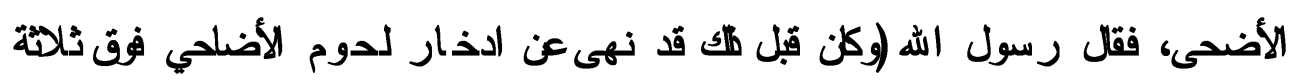

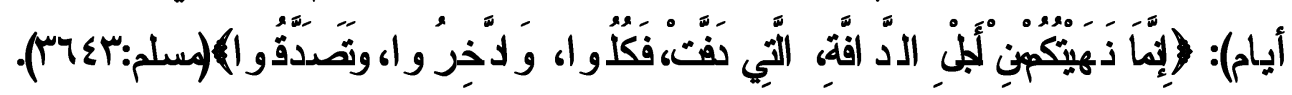

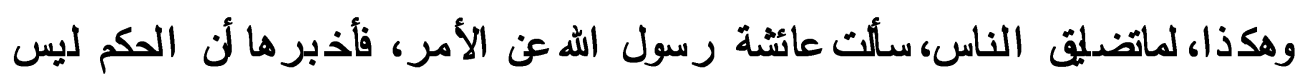

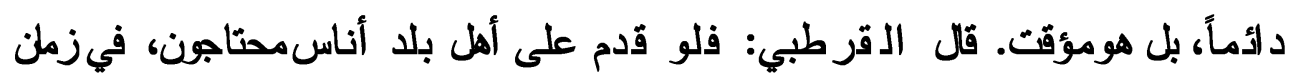

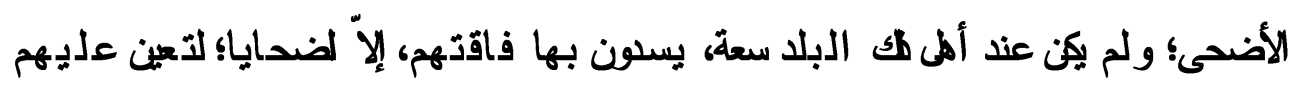

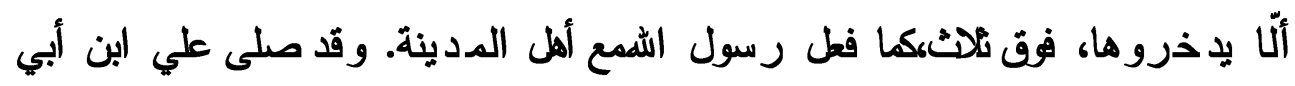

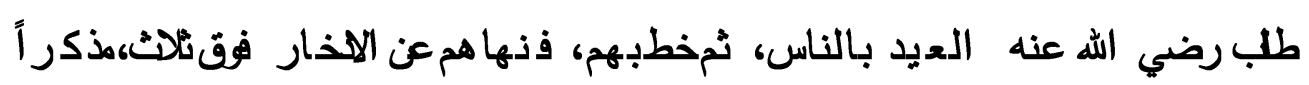

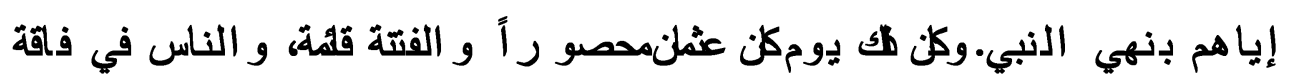

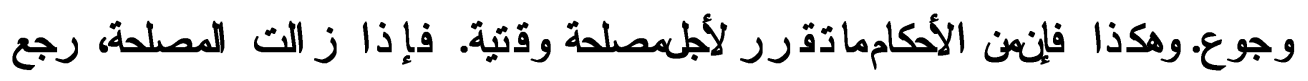

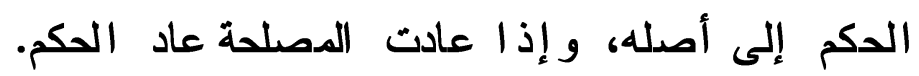




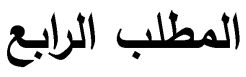 \\ الاستثناء للحاجة}

المقصود بلاسدتناء هو عدم تطبيق الدكم في مق فرد أو جماعة أو حالة، في الأبناء الدوقت الذي بطبق على آخرين؛ لعدم وجودمب در ـ ومن الأمثلة على للك:

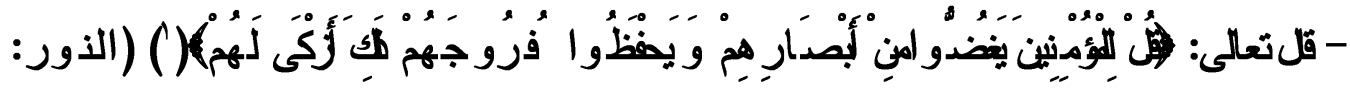

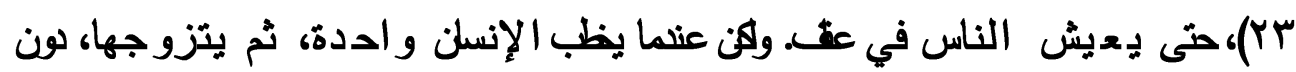

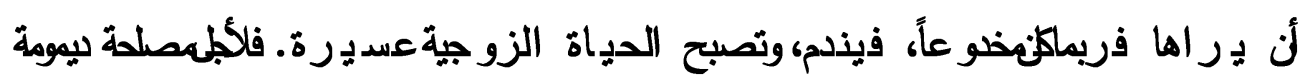

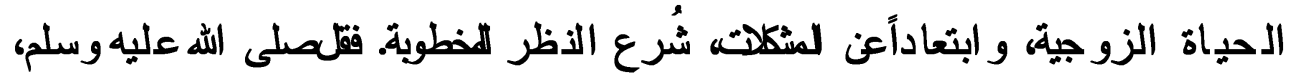

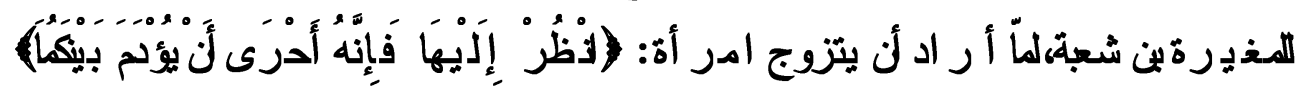

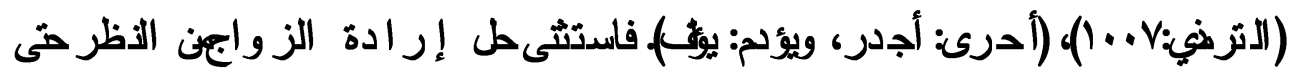

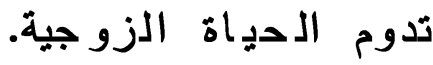




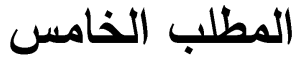

\section{تغير الحكم بسبب تغير علته}

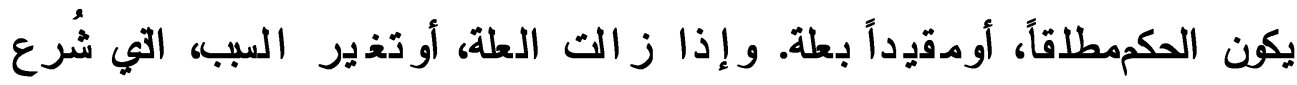
لأجله، تغير لـأك الدكم. ومن الأمثلة على لألك:

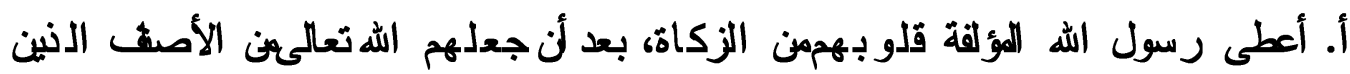

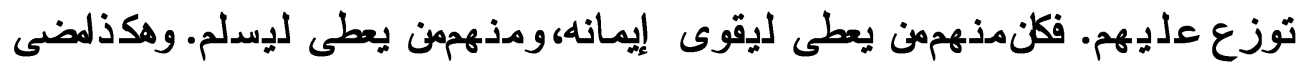

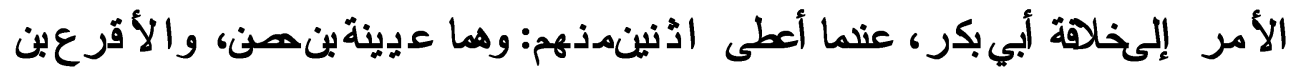

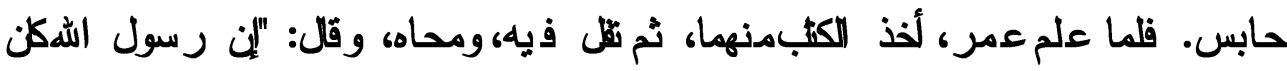

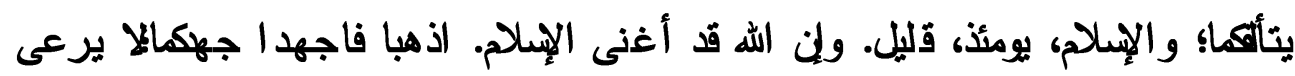
الله عليكما، إن ر عيتما". فترك أبو بكر الإنكار عليه.

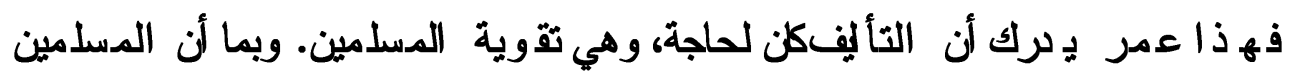

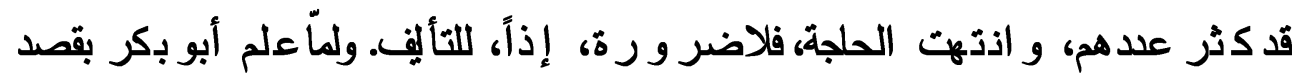

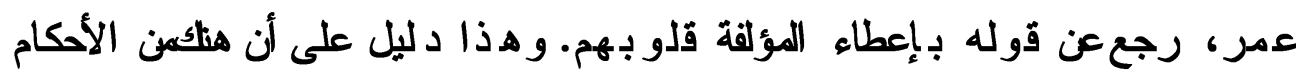
ما يدور مع الدصلحة، ويذغ ير بذغ ير هاء لهاء 


\section{المطلب السادس استحداث أحكام}

- رُوي أن عمر بن الخطب رضي الله عنه، قضى في المر أة، التي يطلقها زوجها فتتزوج غ برده، قبل اهضله عدتها، بأنهاتحرم على هذا الرجل الثاني، حرمثؤبدة؛

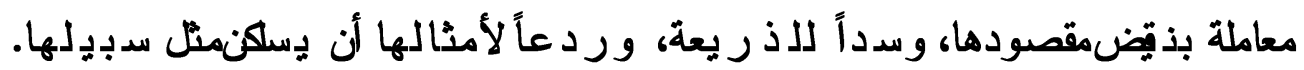

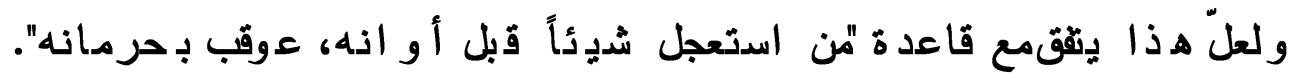
-كل الرسولصلى الله عليه وسدلم يؤتى بشلرب لذمر، فيأمر بضدربه. وسدار الأمر

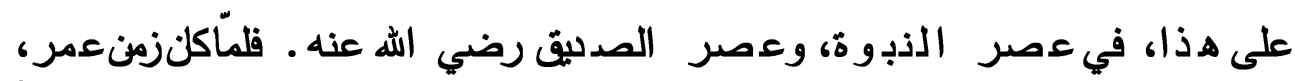

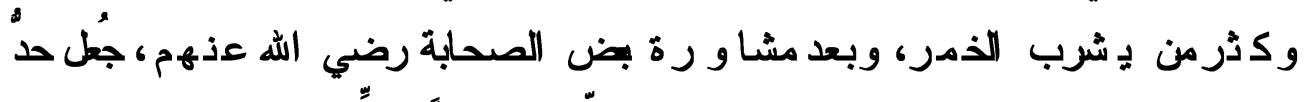

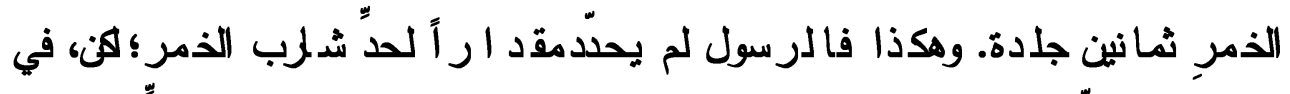

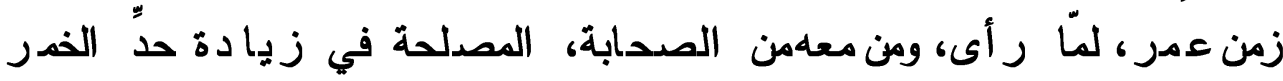

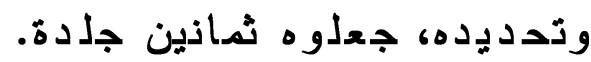

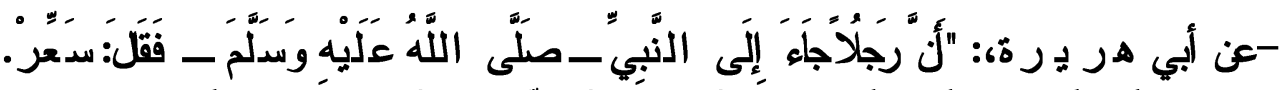

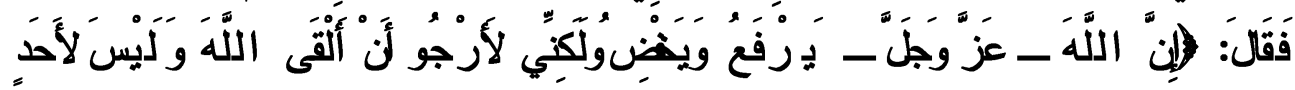

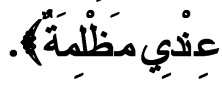

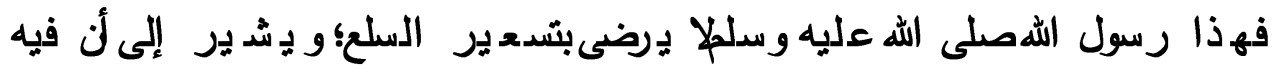

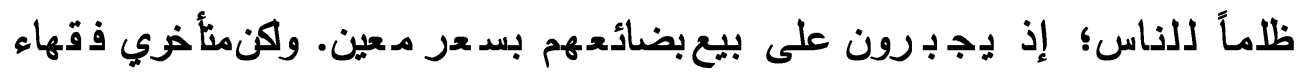

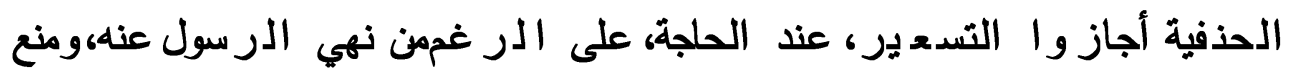

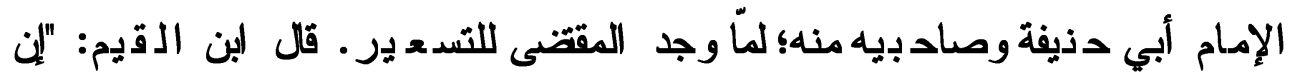

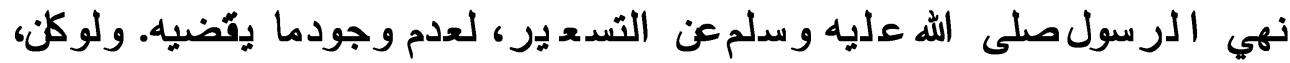


المطلب السابع - (المبان

\section{الاستحسان}

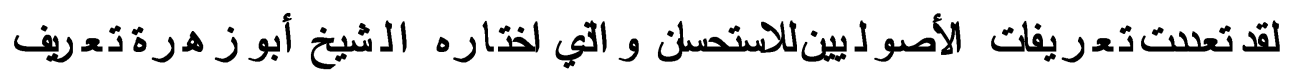

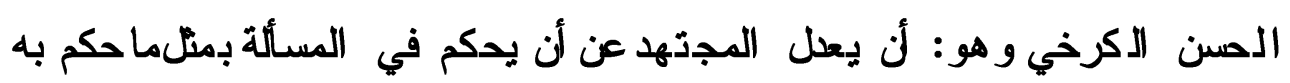

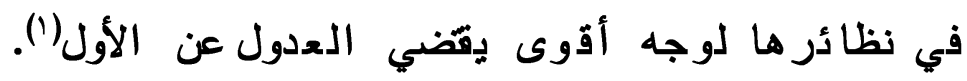

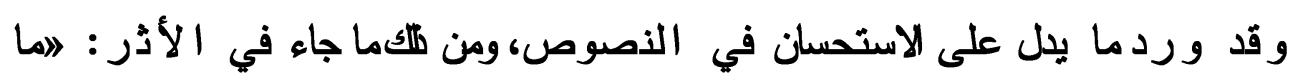

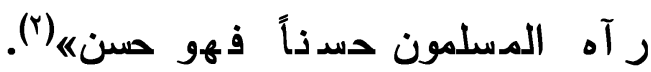
مثال على الفتوى بسبب الاستحسان:

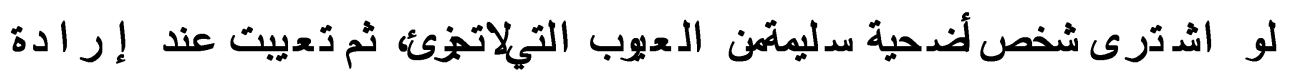

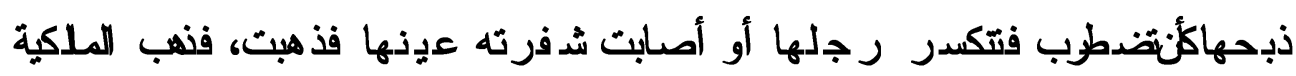
و الشافعية و الحنابلة إلى عدم الإجزاءلكو نهاتعييت قبل الذبح و العبر إدة به، وأما

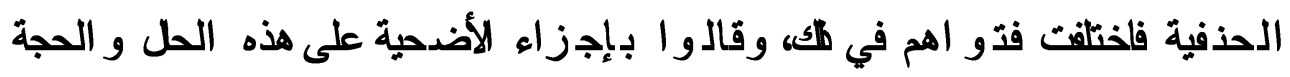

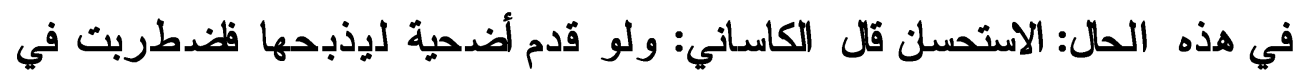

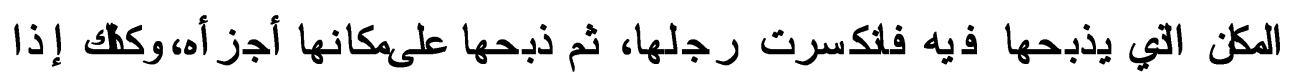
اذقلبت منه الثد رة فأصابت عينها فذهبت.. ثم قال: ووجه الاستحسن أن هذامدا

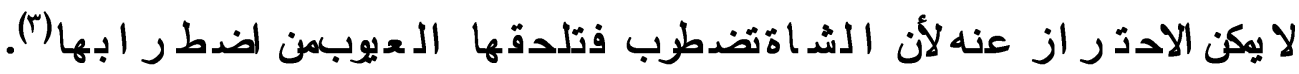

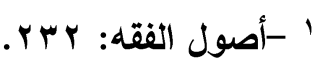

r - انظر بدائع الصنائع: 0 / V . 


\section{المبمث البسادس}

النصوص التي لا تقبل التغيير، والنصوص التي تقبل تغيير الاجتهاد فيها

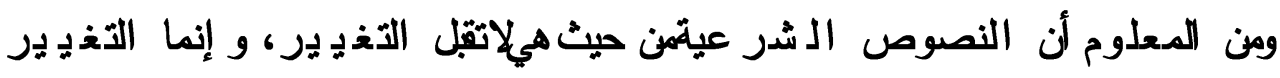

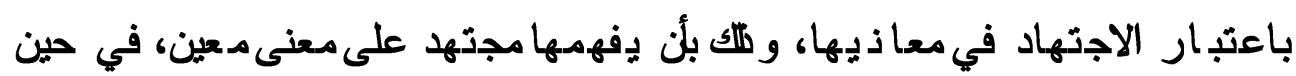

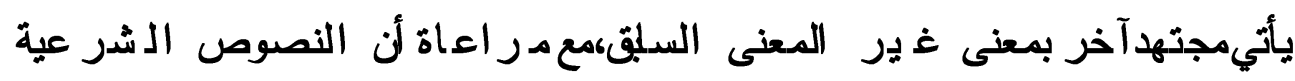

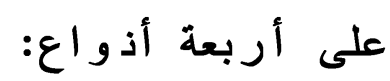

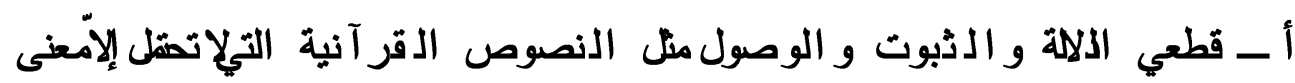

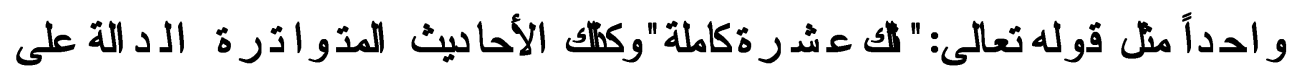

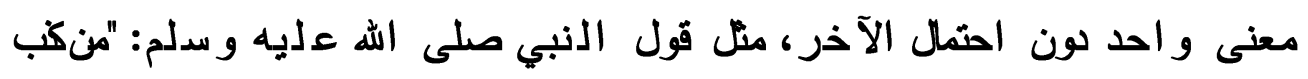

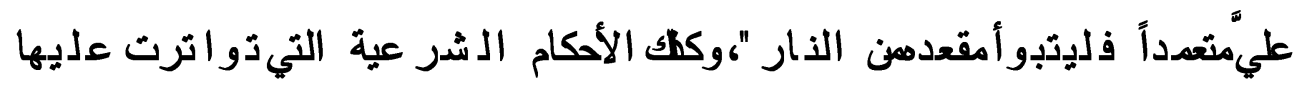
النصوص الشر عيةمثل فيضة الصلاة وعددهاوعدد ركعاتها، و الزكاة و أنصبتها،

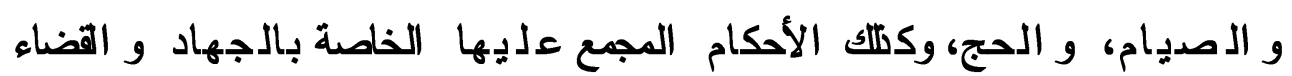

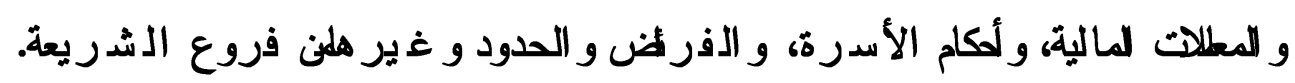

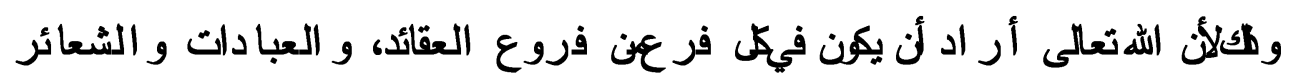

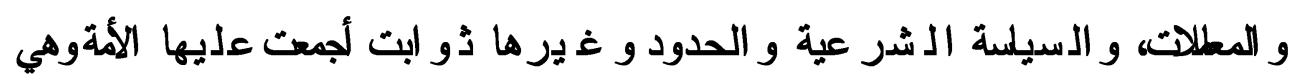

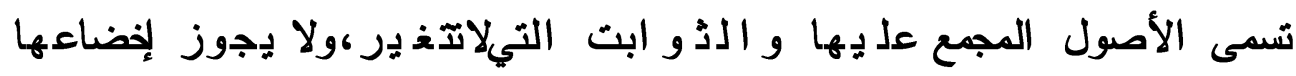

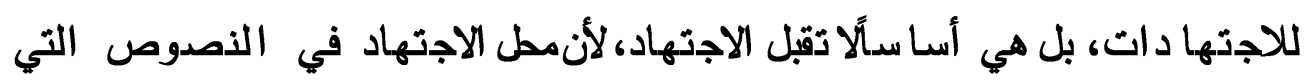

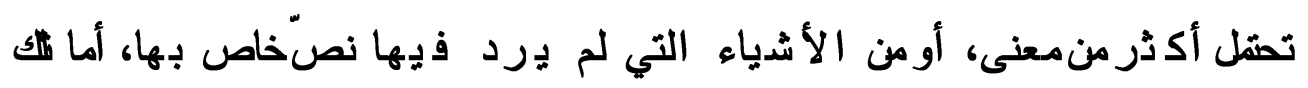

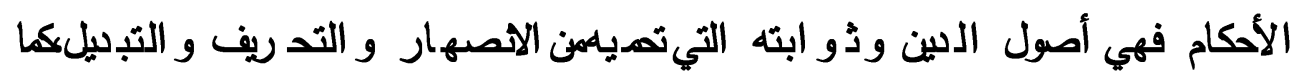

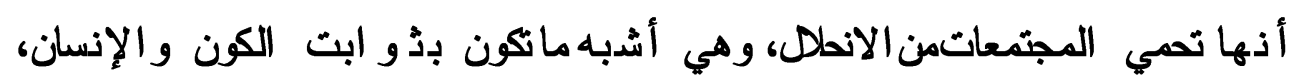

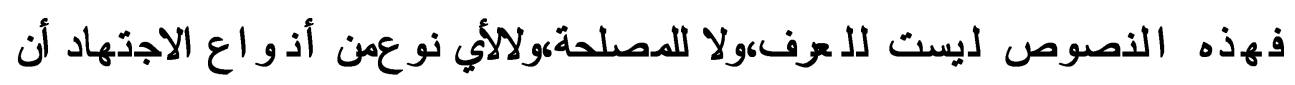

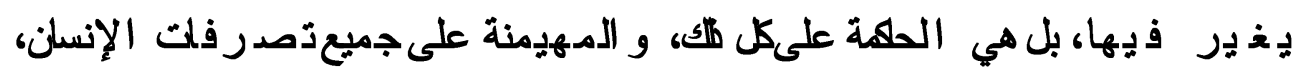


فهي النصوص الآمرة، و القو اعد الكلية و المبلى الأساسية، و الأكام الأساسية لهذه

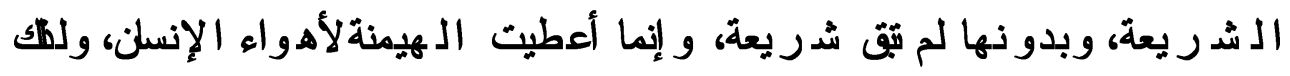

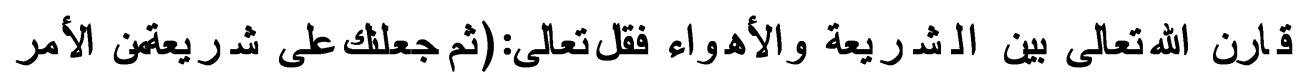

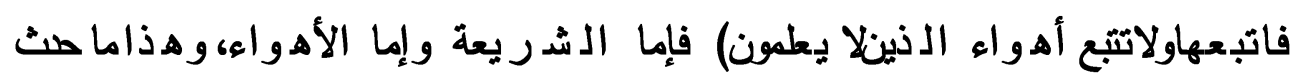

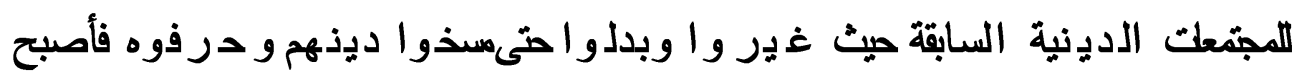

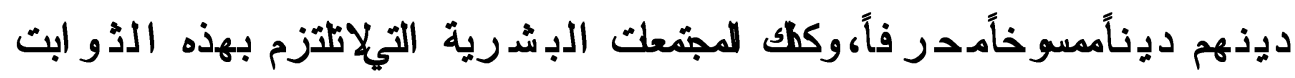

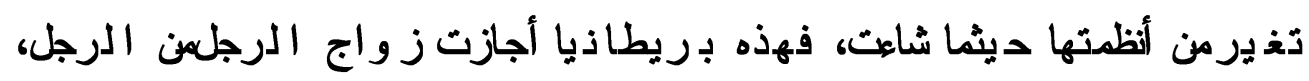

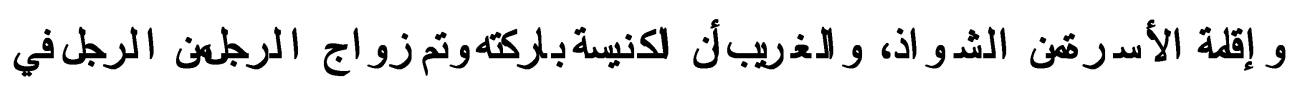
داخل الكنائس.

بـنصوصظنية الذبوت قطعية اللالةوهيمثل النصوص الذبوية التيلاتمثل

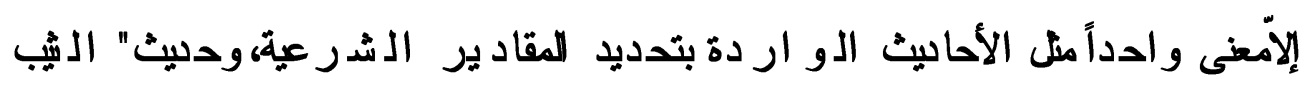

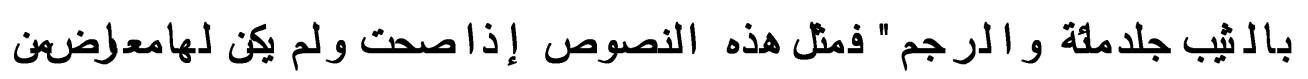
نص" شرعي آخر مدذها أو أقوى منها يجب العل بهامن هذه الهيث المبدأكولا يجوز تر كها بحجة الدصلحة و الـعزف ونحونها.

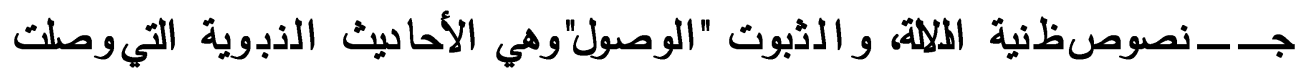

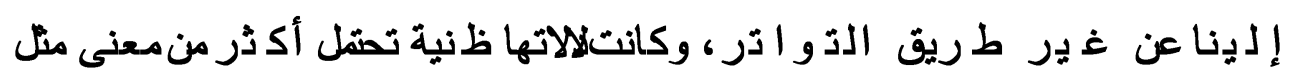

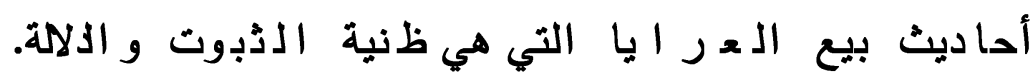

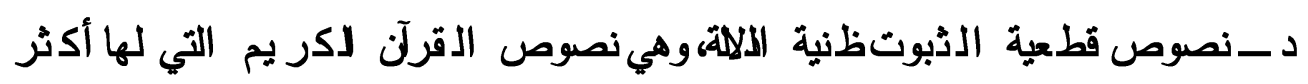

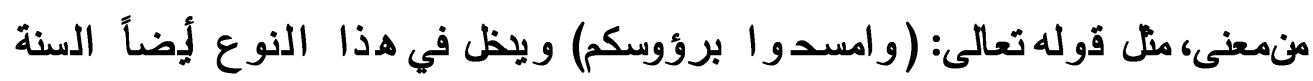

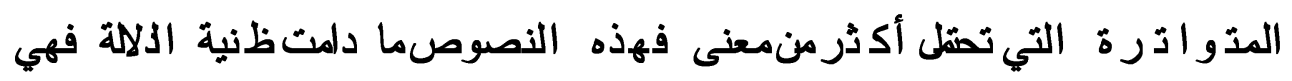

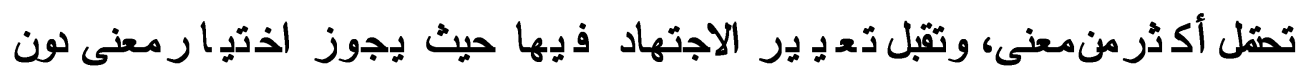

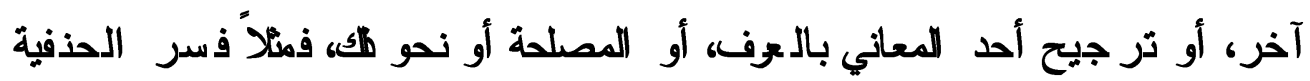
لفظ:" الطعام" في الأحاديث بالبر، وبعضدهم بالحيوب اعتماداً على الـعرف. 
و هذه النصوص التي تقلّتغي ير الاجتهاد فيها لها أذواعمنهاماذكرناهومنها:

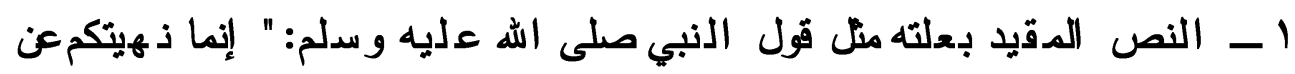

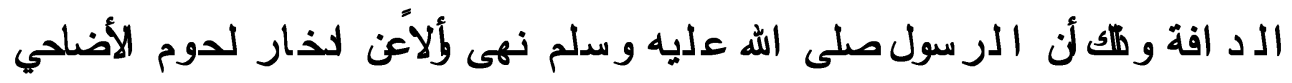

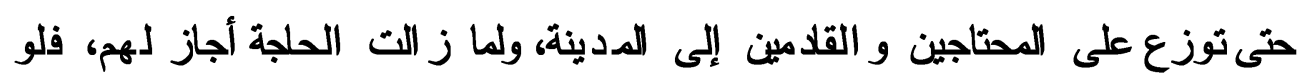

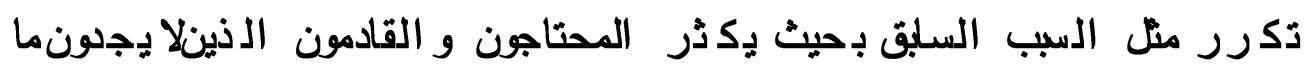

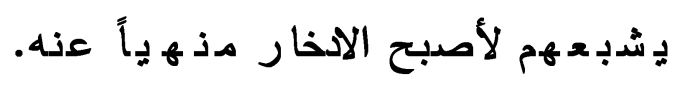

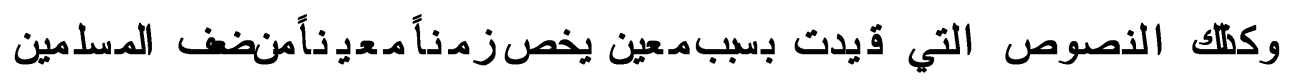

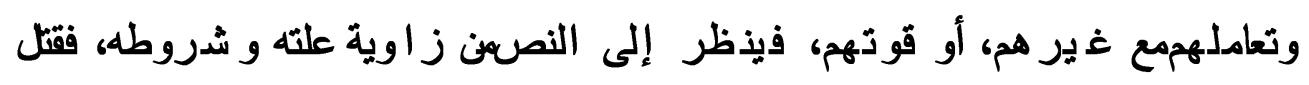

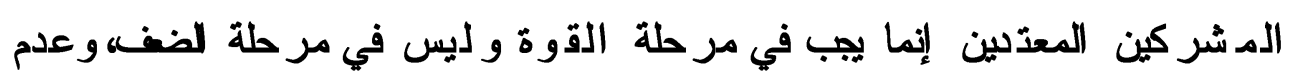
الق د رة .

وبملك نتفادىما أكذر فيه بض العلماءمن القول بالنسخ في الـرآن، فآيات

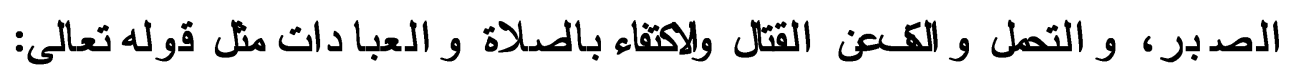

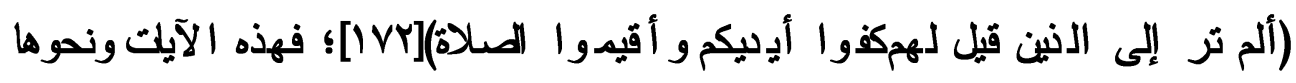
ليست منسوخات بآية السيف ونحو ها و إنماكلمجموعة منها تنزل على الئر حلتها

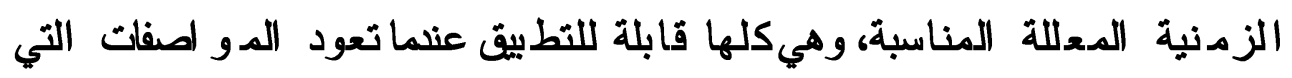

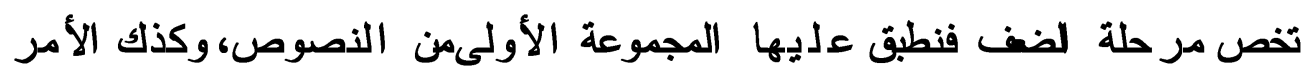

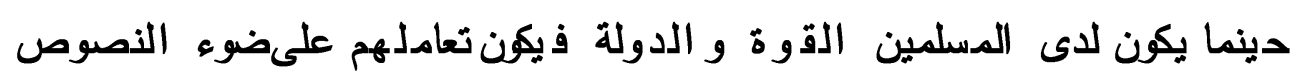

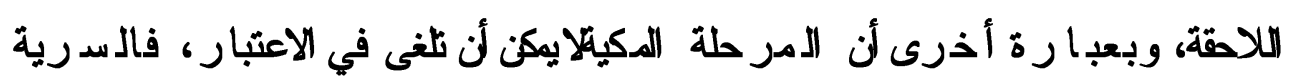

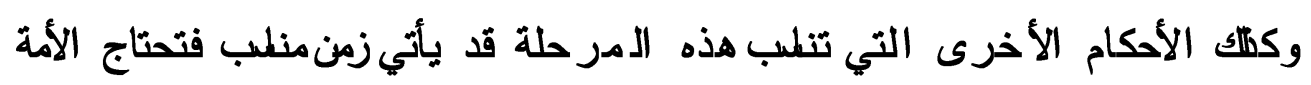

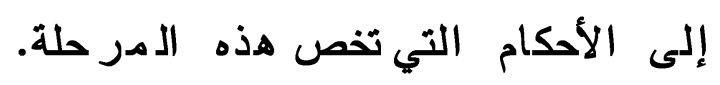

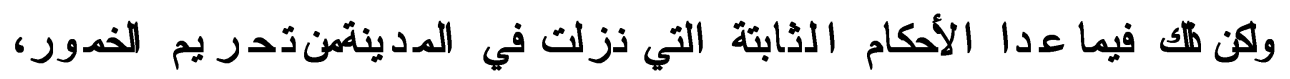

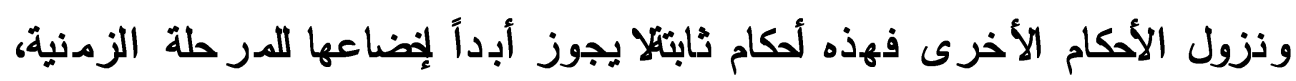

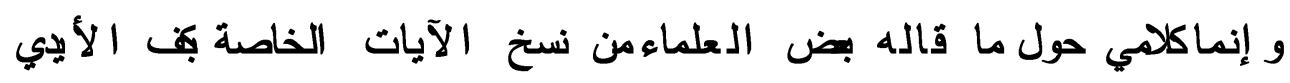


و إقلمة الصدلاة ونحو للك حتى أوصلوها إلىملئة وضضع عشر رة آية، فهذه الآيات كلهاخلمة بسبمدين وزمنمعين قد بعود ويكك رد إذا عادت نفس الموصفات

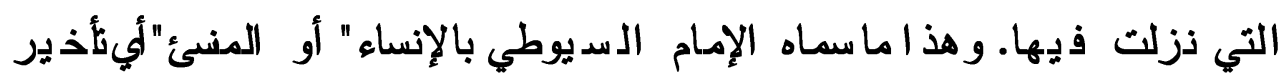

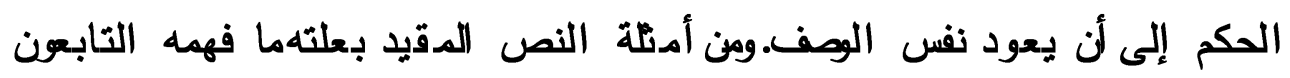

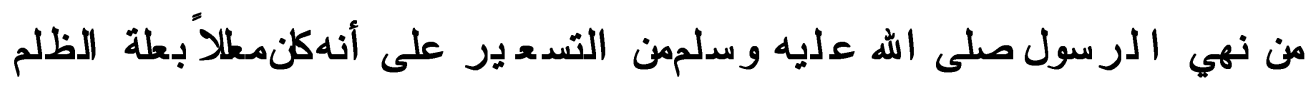

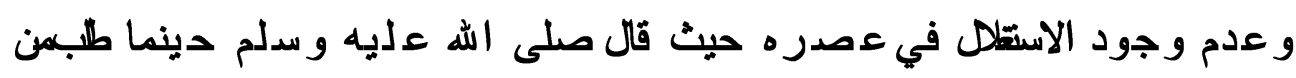

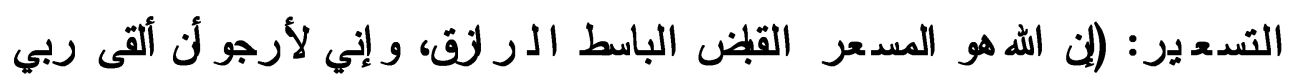

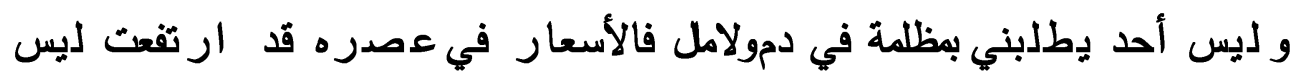

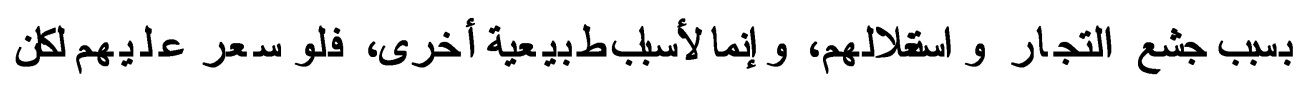

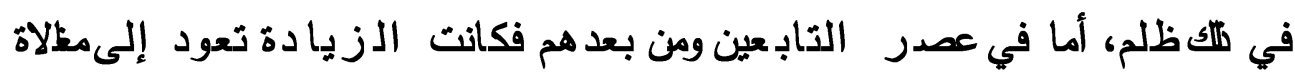

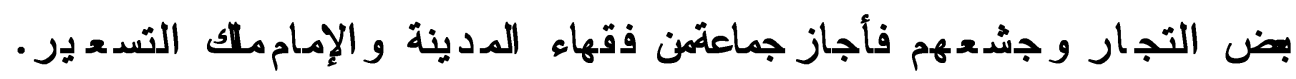

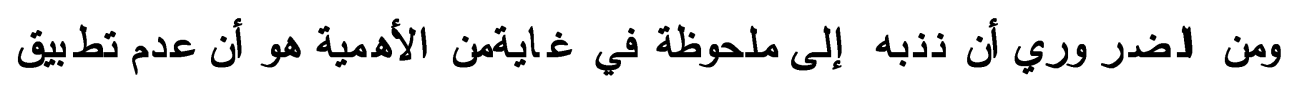

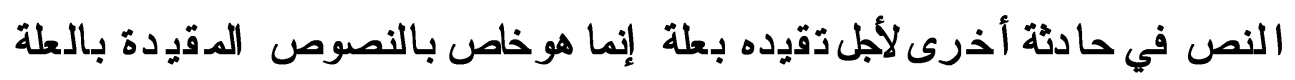

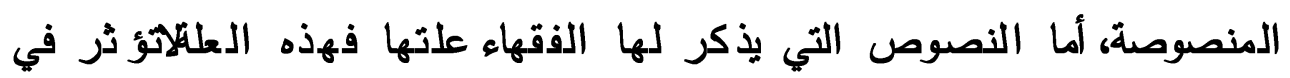

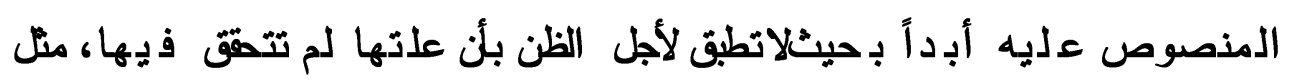

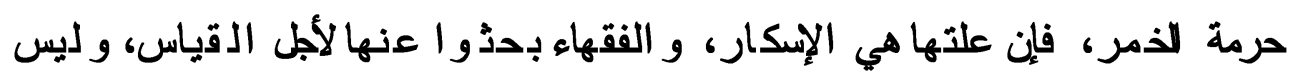

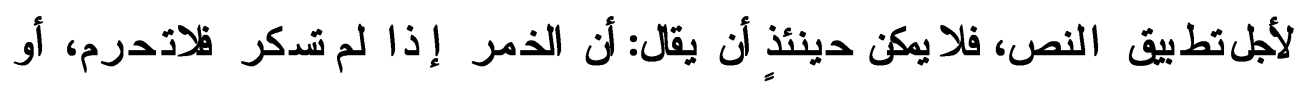

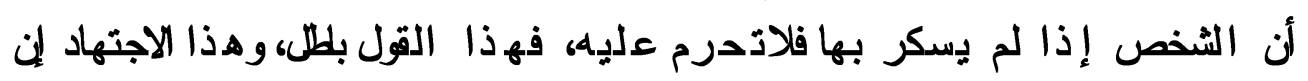

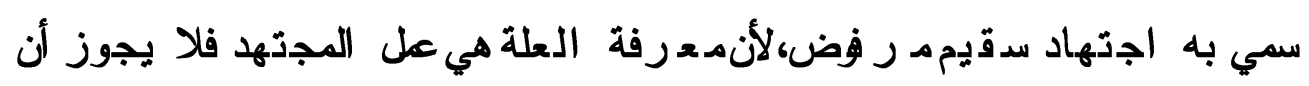

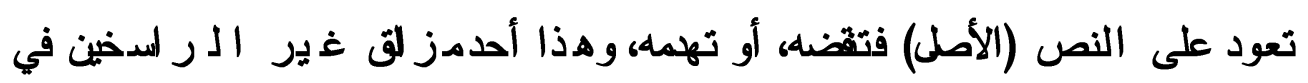

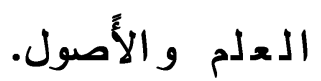

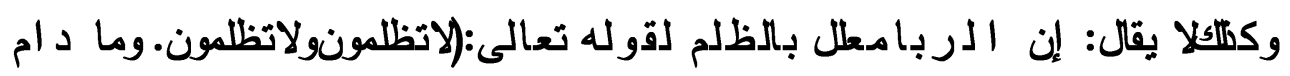

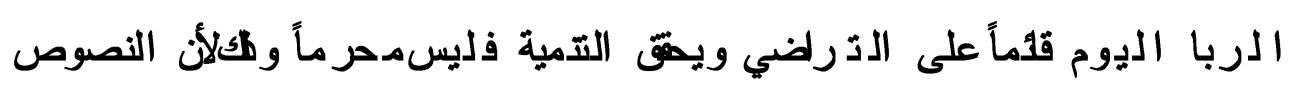


الـر آنية علةومطلقة فيكل الربا فقل تعالى: (ولطل اله البيع وحرّم الربا) [IVT]

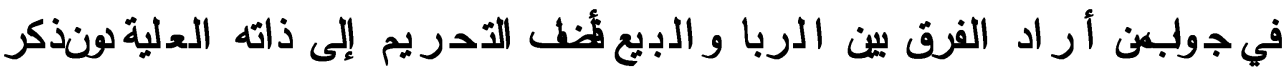

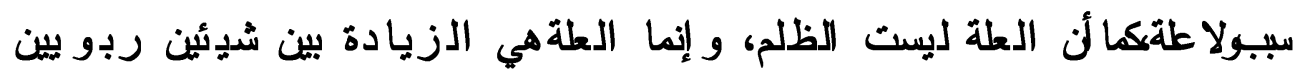

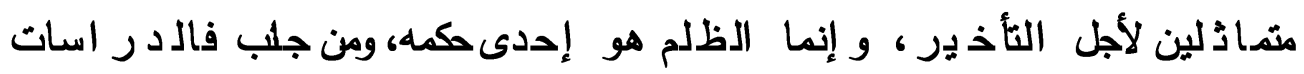

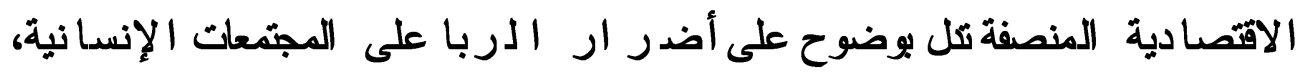

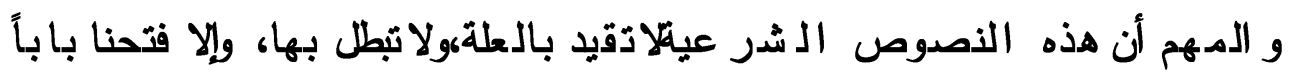

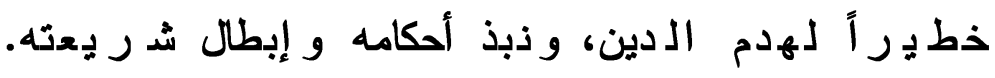

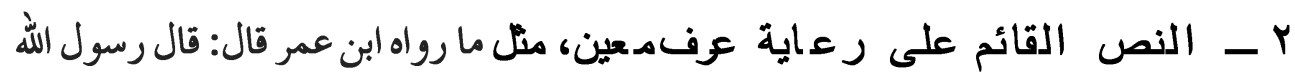

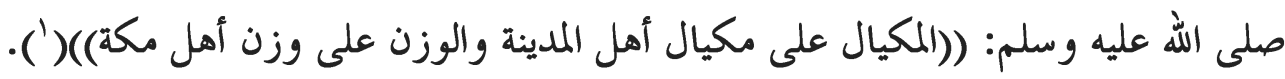

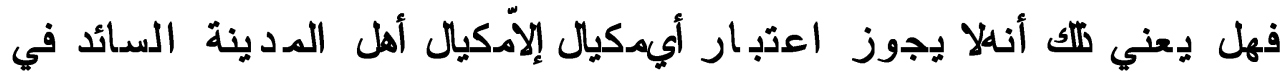

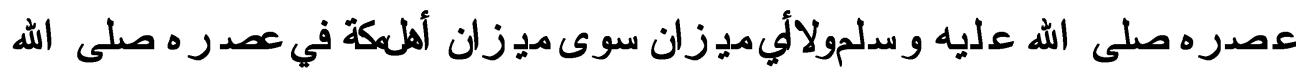
عليه وسدلم ؟فال ر اجحمن أقوال أهل العلم أنهلا يعدّر هالك و إنما يهكن اعتبار

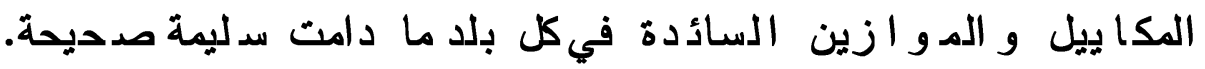

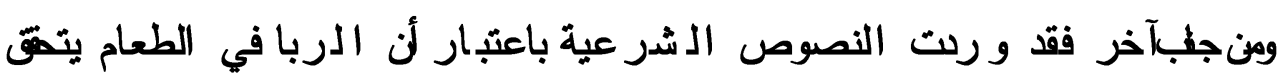

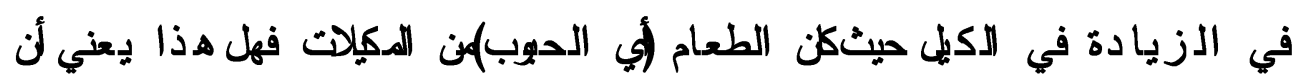

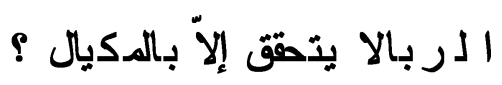

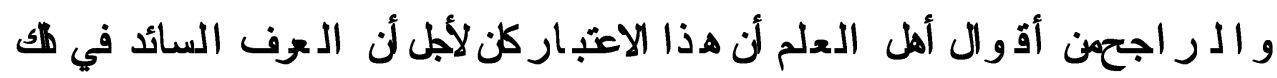

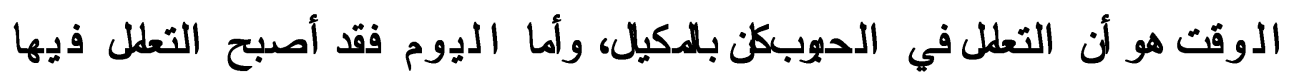

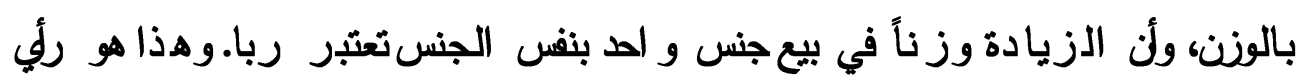

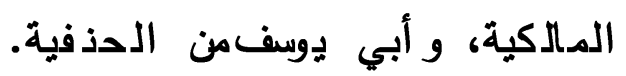

' - أخرجه البيهقي في السنن الكبرى: 1/T آ. 
r - النصوص التي روعي فيها تتظيم بيت المل، ولكمثل الأحاليث الد الة على

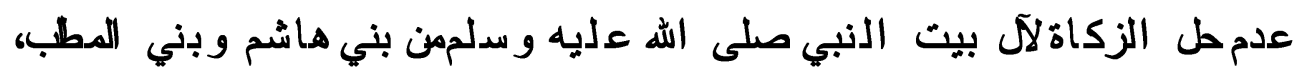

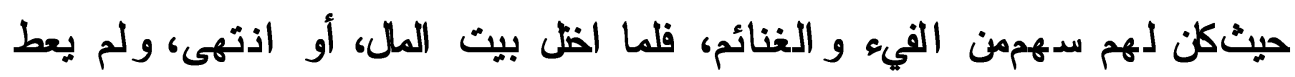

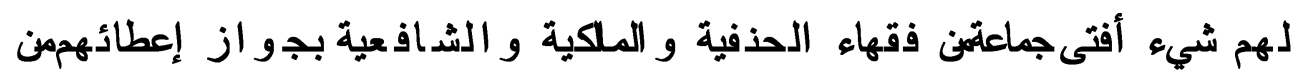
الزكاة و الصددقات.

ع - النصوص الـ ار دةمن الرسول صلى الله عليه وسلم بحكبكونه إماماً مثل:"هن

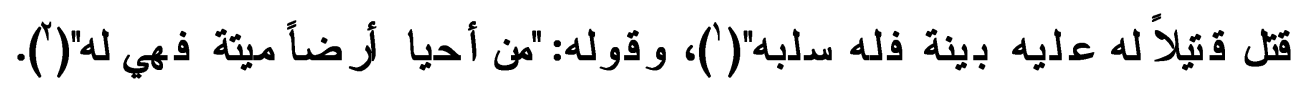

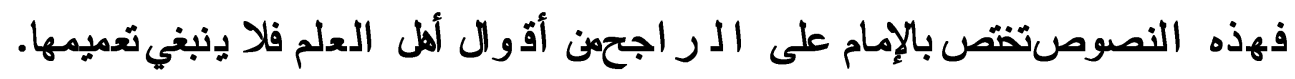
الثبات والتغير : التده

الشدريعة الإنسلاميتمنصفاتها الثبات، فهل هذا الثبات بتنظلهعتغير الفتوى؟

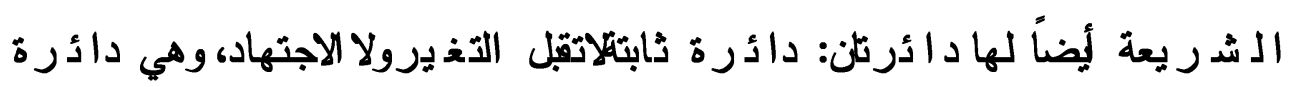

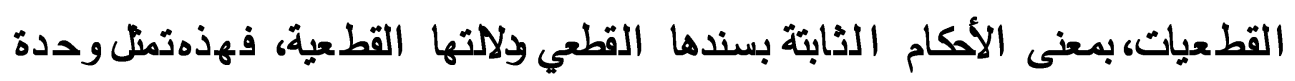

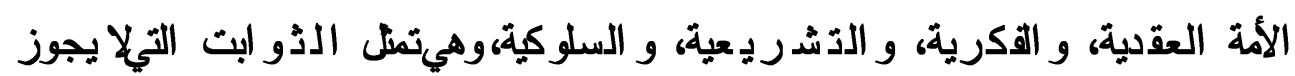

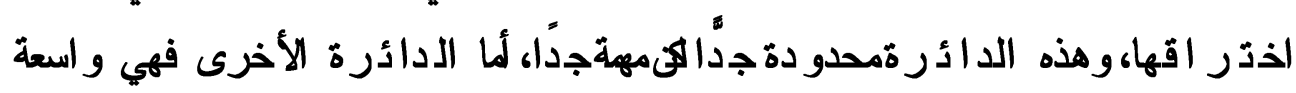

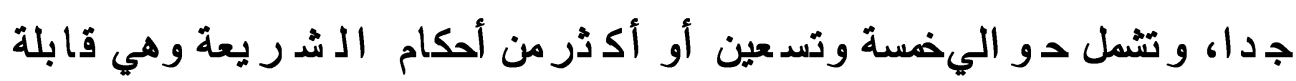

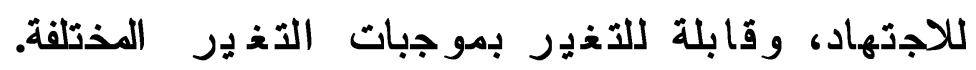

1 - أخرجه الترمذي ، في سننه ، كتاب السير عن رسول الله صلى الله عليه وسلم ، باب :

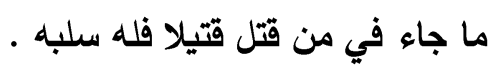
r - أخرجه البخاري ، كتاب المزارعة ، باب : من أحيا أرضاً مواتاً . 


\section{الخاتمة وأهم النتشانُه}

بعد هذا التطول الني عرضنامنخلاله لبيانتغ ير الأحكام بتغير الزمان والأحوال

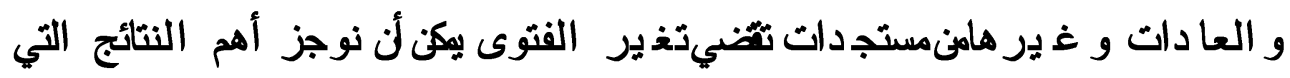

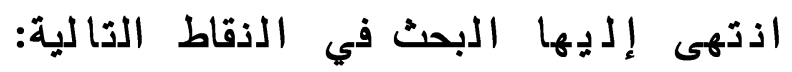

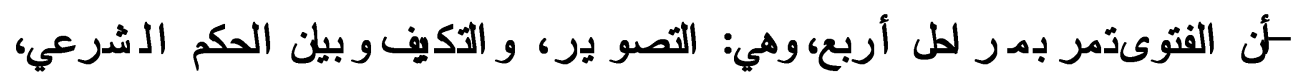

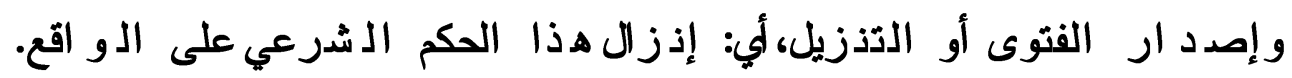

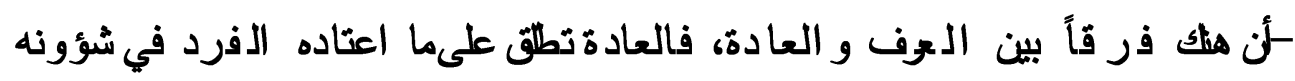

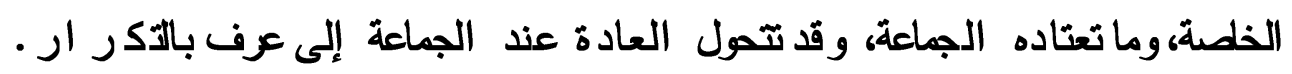

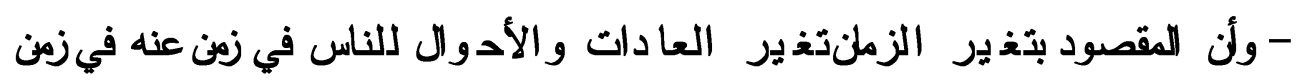

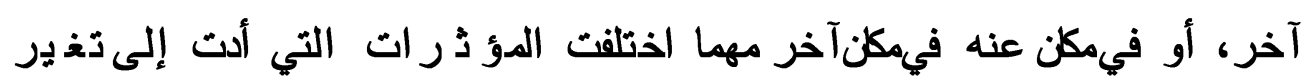

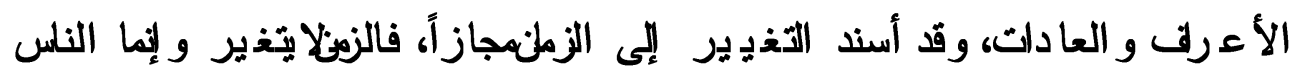

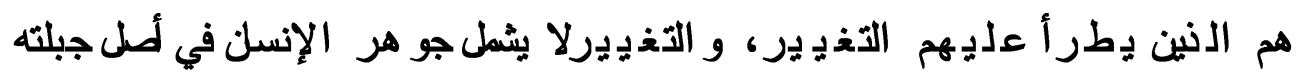

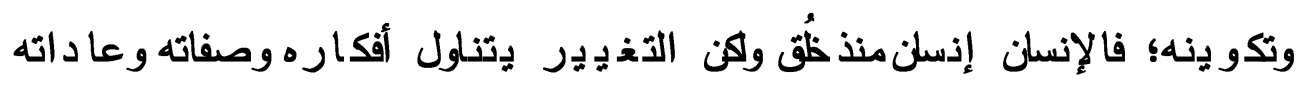

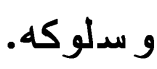

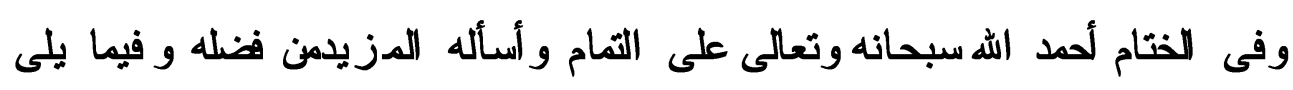

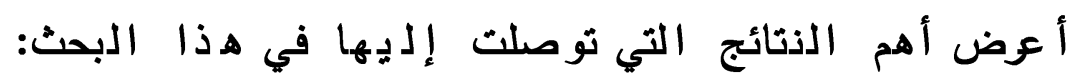

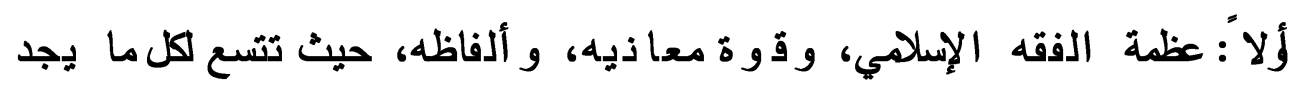

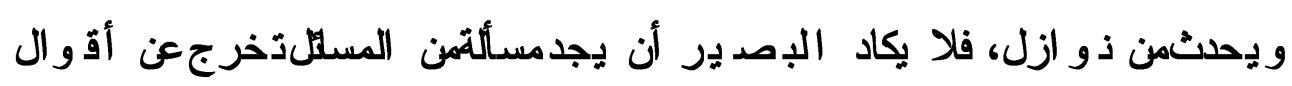

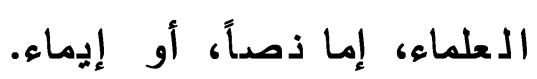

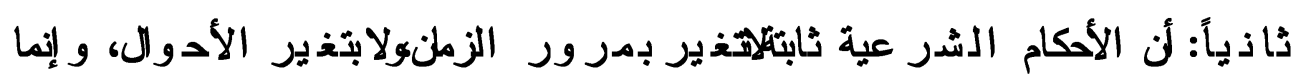

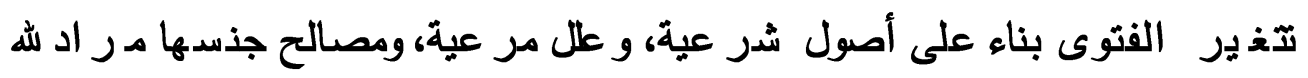

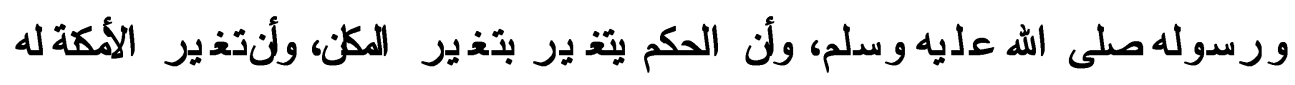




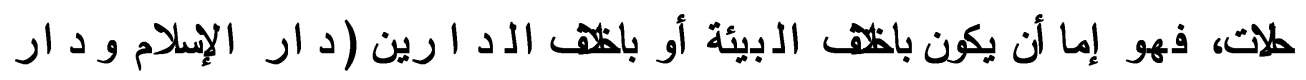
الـ مرب)

ثال ثناً: بناء عليه فلانتخ ير الفتوى بمب الـهوى و التشهي و استحسل العباد

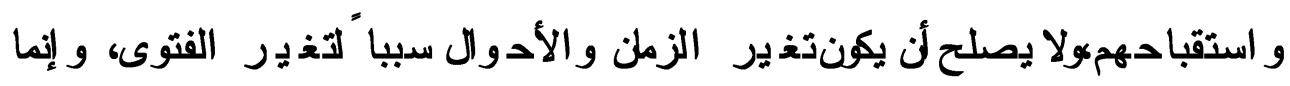

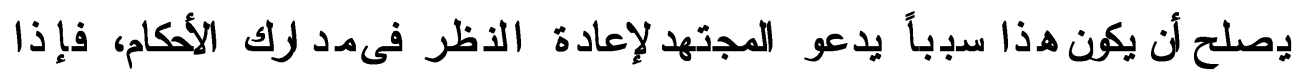

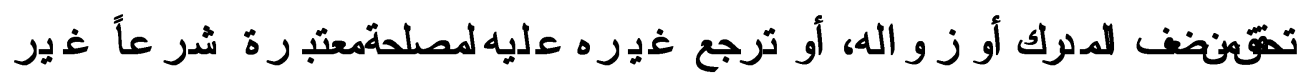

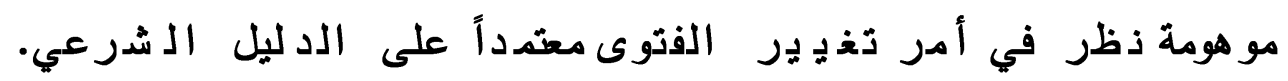

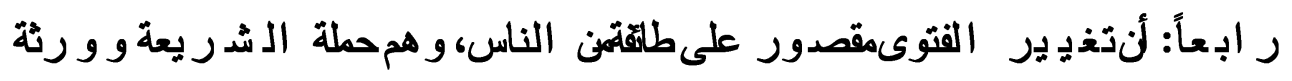

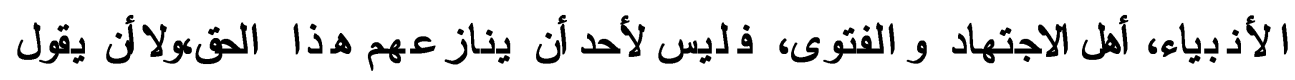

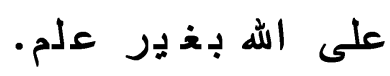
خلمساً: مرونة الفقه الإسلامي، وتجدده، وعدمجدود ده، وقد ر ر أينا فيما عرضنامن

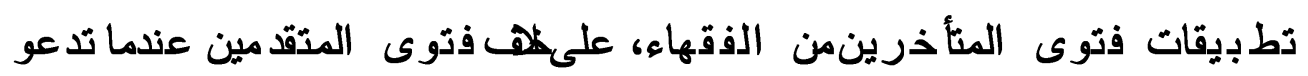

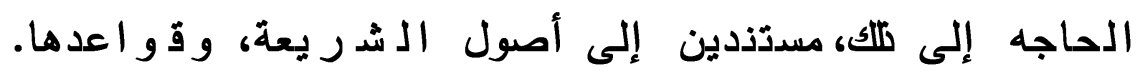

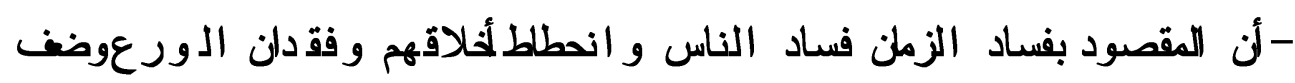

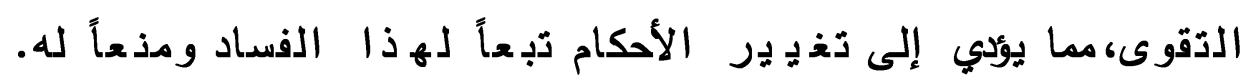

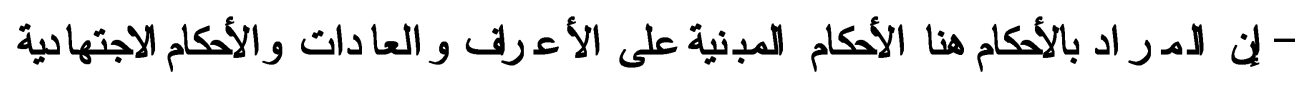

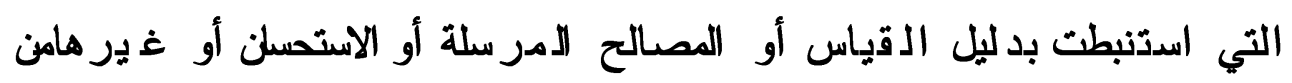

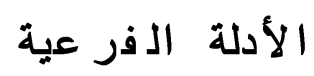

أما الأحكام التيلاتبنى على الأعرف و العاد العائد والأحكام الأساسية الذصية بالأمر

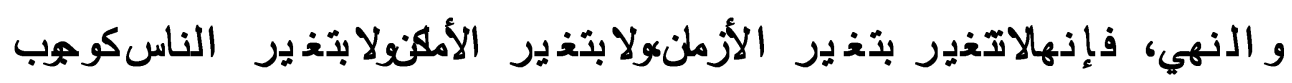

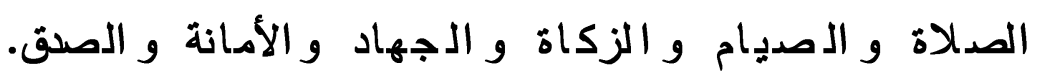

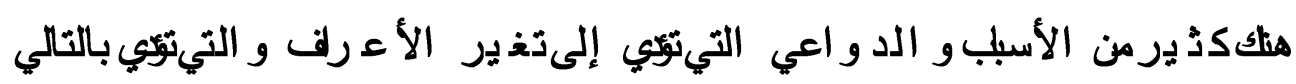
إلى تغ بر الأحكام الاجتهادية، نذكر منها: 
-و جود ظروف تثضي تغ ير إر الدكم.

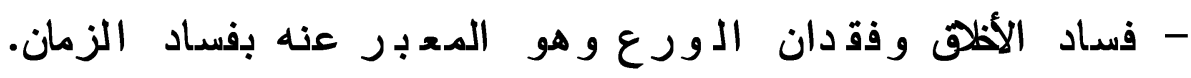

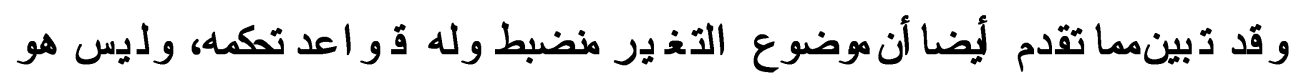

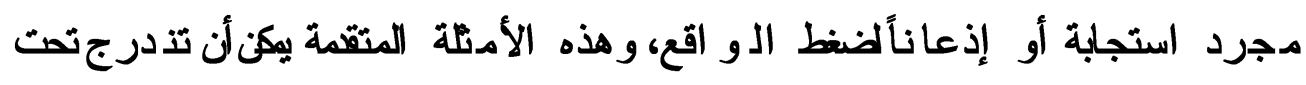

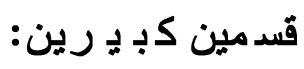

الأول: فتاوىمؤسستمن أول أمر ها على العرفه أو المصلحة المر سلة، ثم يتغ ير

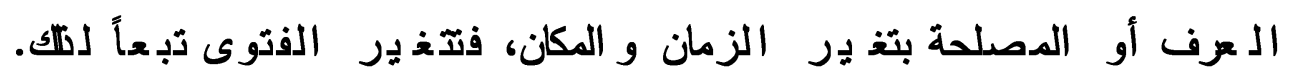

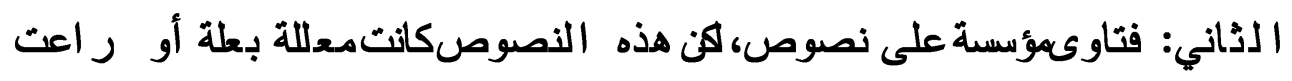

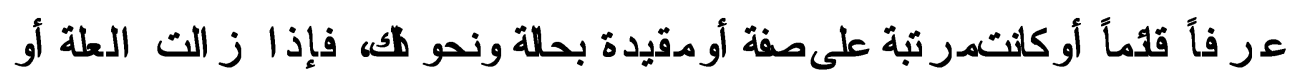

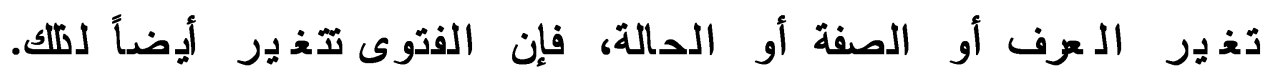
ويمكننا أن نلاحظمما تقدم عدة أ شعردياء:

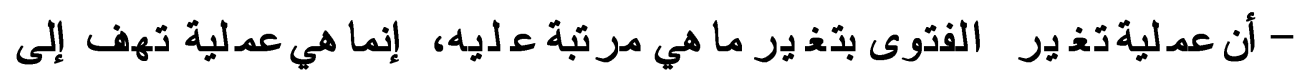

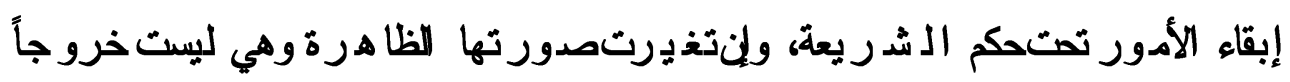

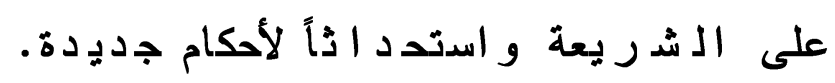
-أن التغير في الفتوى هو تغ ير خاصهن حيث الزملن و المكن أو الشخص التي ذغ يرت في حقهمسدوغات الفتوى، و هذ ذامعناه أن الأمور تككن باقية على ماهي عليه في بـية الأمكن و الأزمان و الأشخاص. -أن الذي يذولى الفذوىطائفةمخصوصة، و هم علماء الـ در يعة الإنلامية، و هم و رثة الأذبياء و المو قعونعن رب العلامين -حتىلا يفتح البب و اسعاً لبض الباحثين و الكب للقول عى الله بغر علم بحجة المصلحة حيناً أو تغير الأع رلف

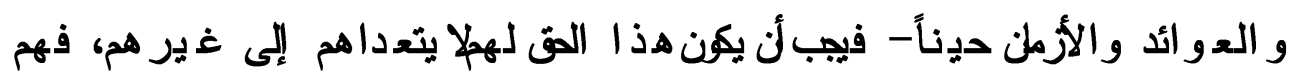

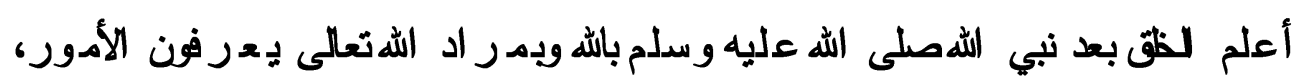


وي يعر فون المصالح وضدها، يقولون فيحث هذه العو ائد والأعرق والأدوال والأزمنة

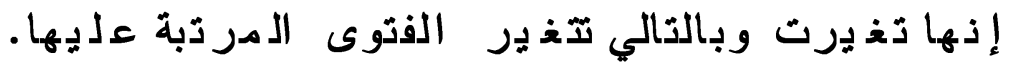

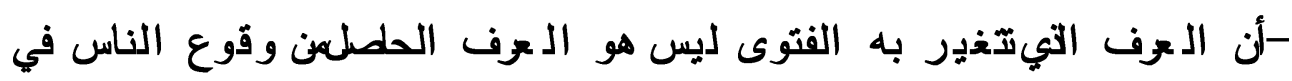

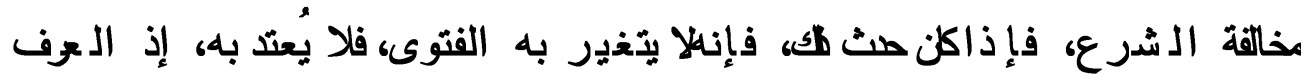

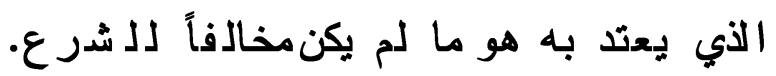

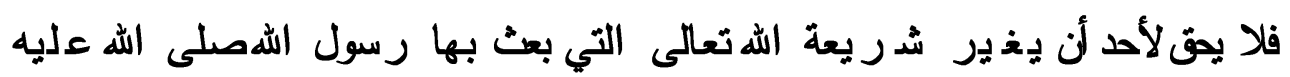

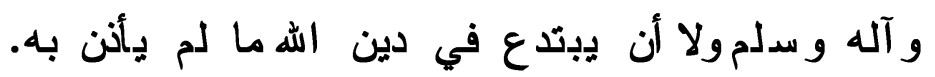

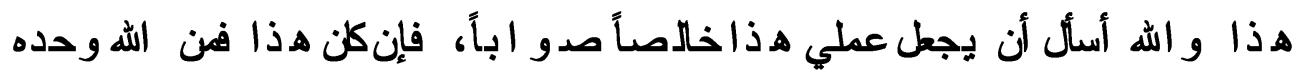

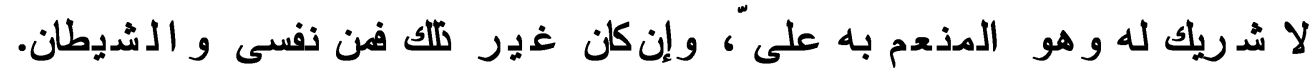

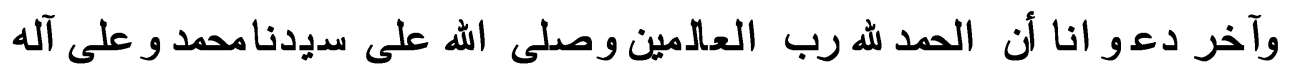

وصدبه ومن والاه.

\section{ثَبت المصادر والمراجع}

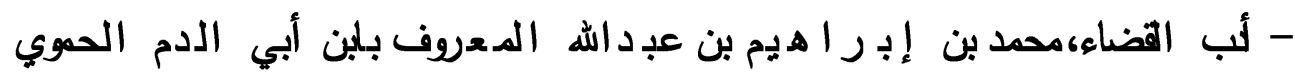
الشدافعي. تدقيق الدكتور محمد الز ديلي، طبعة (بدون).

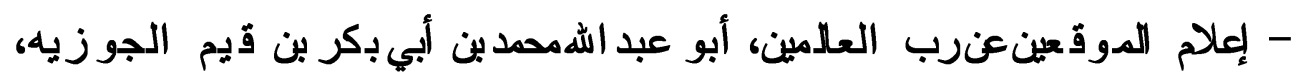

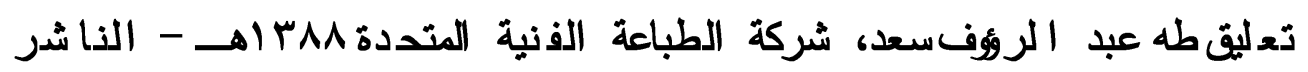
مكتبة الكليات الأز هرية.

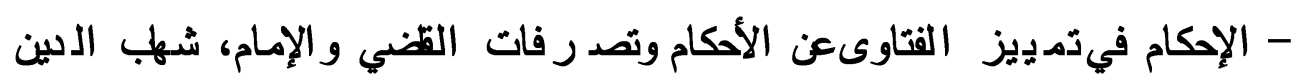

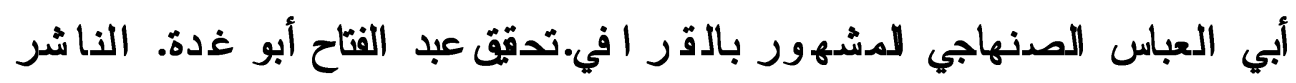

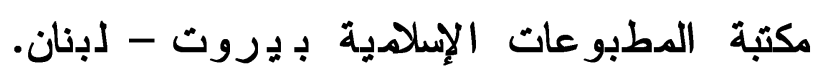

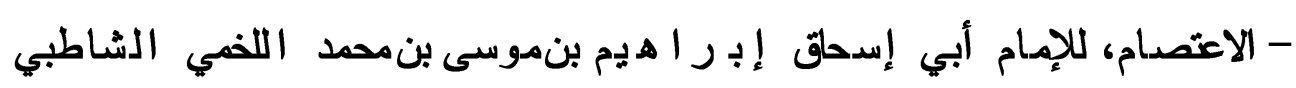

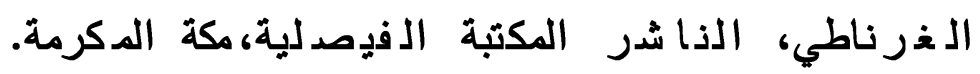


- الثبات و الشمول في الشدر يعة الإيسلامية، الكثور عابدبنمحد السدياني، ذشدر وذو زيعمكثبة المذار ة -مكة الدكرمة - الطبعة الأولى - 1 ، ع اهـ.

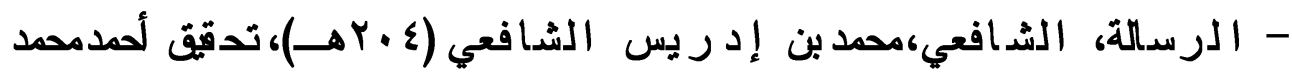
شاكر - د ار الكب العلمية، بـدروت لبنان.

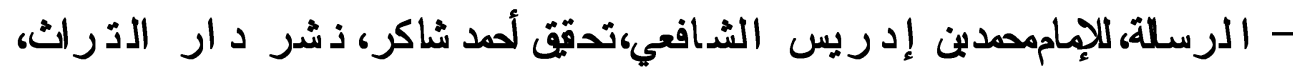

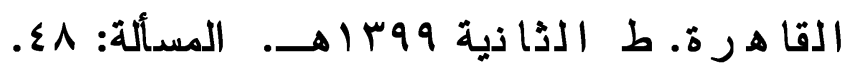

- الشرح لكب ير علىختصر ذليل، أبي البركلت سيي لمد الدر د ير،مطبوع على هامش حاشية الدسدوي على الشرح المنكور، د ار إحياء لآب العر بية، عيس البابي الدلبي بمصدرد. - الفوق، شهب الدين أبو العباس الصدنهلي لمشهور بالقر افي. د ار الدعرفة بـ بـرووت - لبان. - المثل الفقهي العام، الز رقا، الكتور مصطفى لحمد الز رقا، د ار الفكر،دمثق الطبعة التاسعة (941 (19-ـ). - المدونة لاكبرى، ر و اية الإمام سحنونبن سديد التنوخيعن الإمام عبد الرهن بن القاسم العثقي،ن إمام د ار الهجرة إملكبن أنس الأصبحيهمبعة السعادة

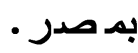
- المد افقات في أصول الشدريعة، إب ر اهيم بنموسى اللفي الغرنلطي المكي أبو

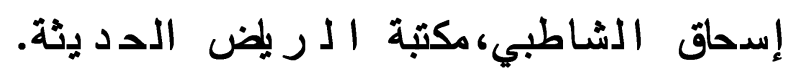
- بحث ذغ ير الفذوى، للدكذور عبد الله بن حمد العظيمل. - بدائع الصنائع تر تي الشدر ائع،علاء الد بن أبوبكر بنمسعود الكاساني،مطبعة

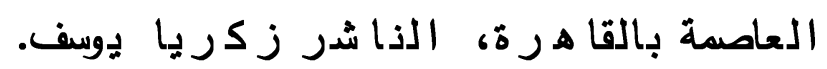
- ذب يين الحقق شرحكنز الدقلق، فخر الدين عثمن بن علي الز يلعي الحنفي، ط/ - - د ار المعرفة للطباعة و الذشر - بـ بـروت لبنان. 
- تيسدر الاكر يم الرمن في تفس يركلام المنلن، للشيخ عبد الرمنبن ناصر

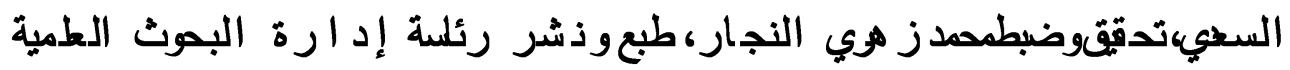
و الإفتاء و الدعوة و الإرشاد بالسعو دية.

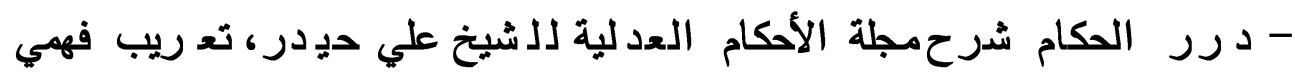

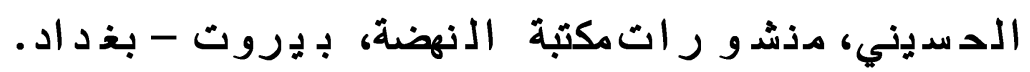

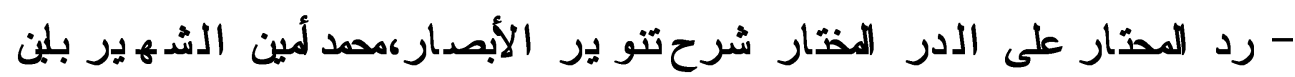

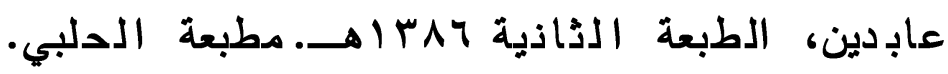

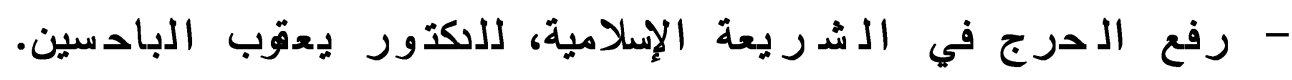

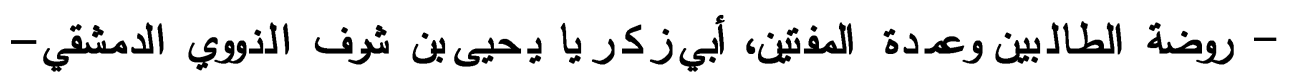
المكب الإسلامي للاطباعة و الذشر .

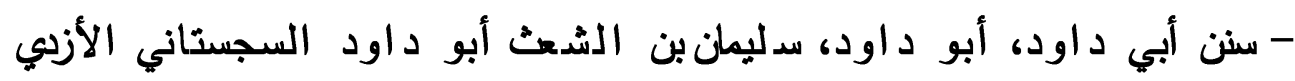

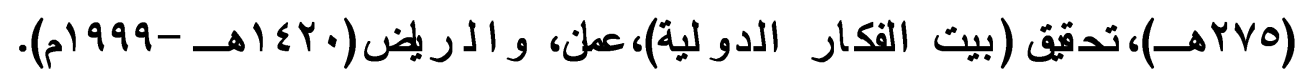

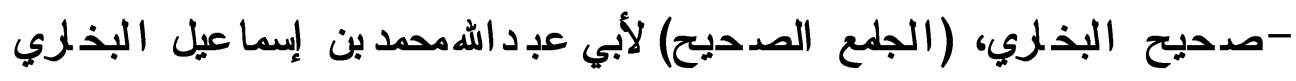

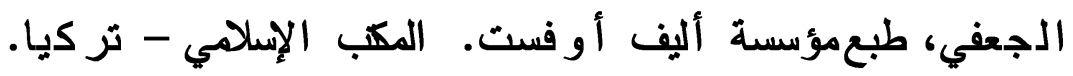

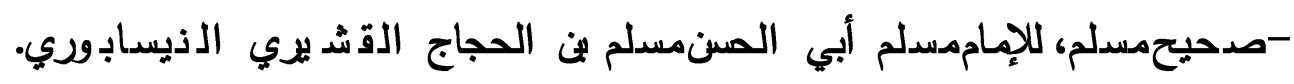

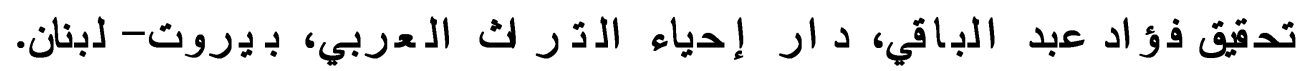

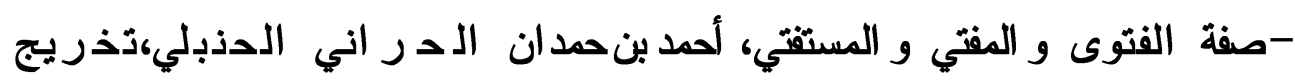

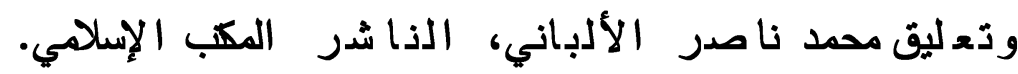

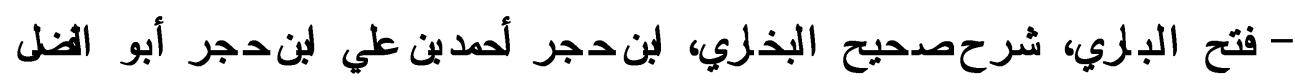

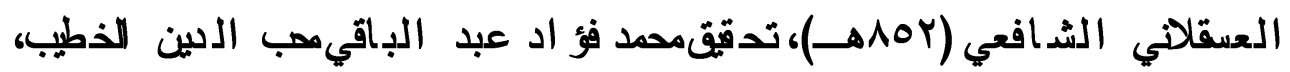
د ار المعر فة، بـ يدروت - لبنان.

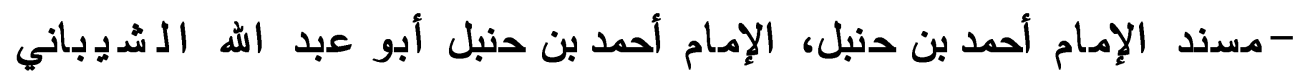

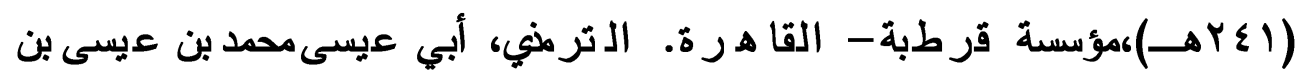




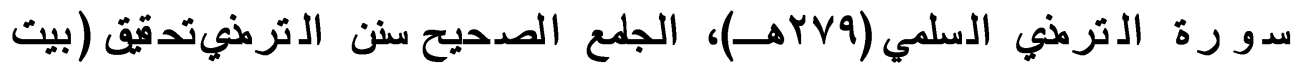

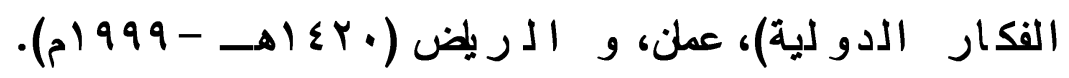
شدجرة الذور الزكية، في طبقات الملاكية لل شيخمحمدبنمحمدخلفه طبعة د ار الف الفر

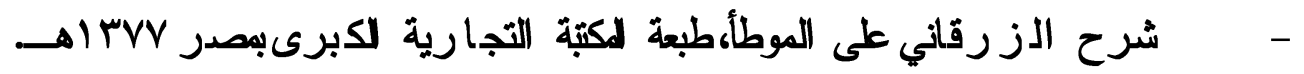
الـ قرطبي، أبي عبداللمحمدبن لحمد الأثصلري الـرطبي (IVIهـ)، الجلمع

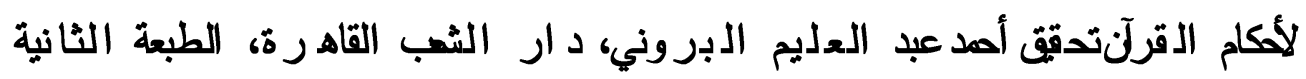
(-) I MVY) قو اعد الأككام فيمصالح الأنام، العز بن عبدالسلام، أبيمحد عز الدين عبد العزيز بن عبد السلام السلمي، (.77هـ)، د ار الكب العمية، بـ يروت لبنلن. القو اعد الفق هية(مفهو مها - نشأتها -تطور ها - د ر استمؤلفاتها - أدلتهامهدتها -تطبيقاتها)تألب على لحمد الذوي، د ار القلم،دمشق الطبعة الدالثة $\rightarrow$ )

كب الجمع في السنن و الآدلب و المغزي و التأ ريخ لأبيمحمدعبدالله بن أبي

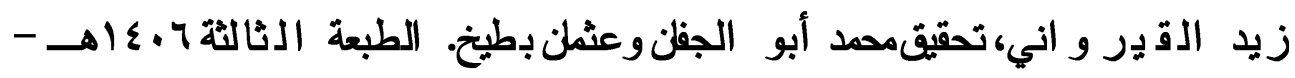

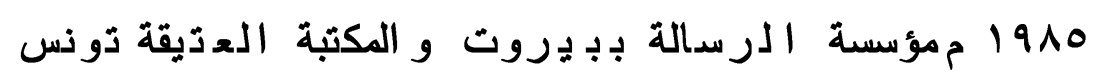

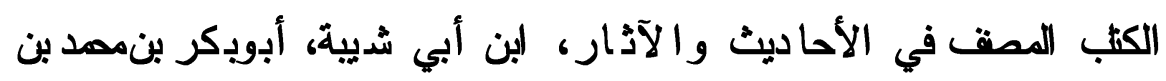

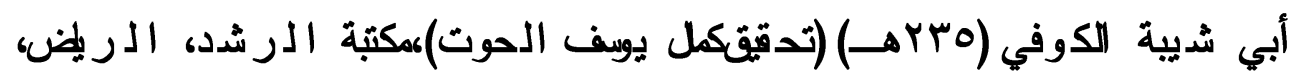
الطبعة الأولى (9 ، ع اهـهـ). المبسوط الشمس السين السرخس، الطبعة الثالثةهوساهـ د ار المعرفة للاطباعة و الذشرر، بـ بـروت لـبنان. 
المستصفى في علم الأصول، الغز الي: أبي حامدمحد بنمحمد بنمحمد الغز الي (0.0هـ)، تدقيقمحمد عبدالسلام عبد الشافي، د ار الكب العلمية،

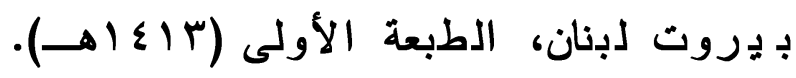

